\title{
FLUXES, TRENDS AND SOURCE CHARACTERISATION OF ATMOSPHERIC TRACE ELEMENTS
}


FINNISH METEOROLOGICAL INSTITUTE

CONTRIBUTIONS

NO. 164

\title{
FLUXES, TRENDS AND SOURCE CHARACTERISATION OF ATMOSPHERIC TRACE ELEMENTS
}

\author{
Katriina Kyllönen \\ Department of Chemistry \\ Faculty of Science \\ University of Helsinki \\ Helsinki, Finland
}

ACADEMIC DISSERTATION in Analytical Chemistry

To be presented, with the permission of the faculty of Science of the University of Helsinki, for public criticism in Auditorium A110 of the Department of Chemistry on October 30, 2020, at 12 o'clock noon.

Finnish Meteorological Institute

Helsinki 2020 
ISBN 978-952-336-103-4 (paperback)

ISNN 0782-6117

Edita Prima Oy

Helsinki 2020

ISBN 978-952-336-104-1 (pdf)

http://ethesis.helsinki.fi

Helsingin yliopiston digitaaliset opinnäytteet

Helsinki 2020 


\begin{tabular}{|c|c|}
\hline Author's address: & $\begin{array}{l}\text { Katriina Kyllönen (née Pyy) } \\
\text { Finnish Meteorological Institute (FMI) } \\
\text { P.O. Box 503, FI-00101 Helsinki, Finland } \\
\text { katrina.kyllonen@fmi.fi }\end{array}$ \\
\hline Supervisors: & $\begin{array}{l}\text { Research Professor Hannele Hakola } \\
\text { Finnish Meteorological Institute } \\
\text { Air Composition Research } \\
\text { Helsinki, Finland } \\
\text { Docent Jussi Paatero } \\
\text { Finnish Meteorological Institute } \\
\text { Research and Special Measurements } \\
\text { Helsinki, Finland }\end{array}$ \\
\hline Reviewers: & $\begin{array}{l}\text { Professor Paavo Perämäki } \\
\text { University of Oulu } \\
\text { Inorganic Analytic Chemistry } \\
\text { Oulu, Finland } \\
\text { Docent Jorma Joutsensaari } \\
\text { University of Eastern Finland } \\
\text { Department of Applied Physics } \\
\text { Kuopio, Finland }\end{array}$ \\
\hline Opponent: & $\begin{array}{l}\text { Professor Henrik Skov } \\
\text { Aarhus University } \\
\text { Department of Environmental Science, Atmospheric } \\
\text { Measurements } \\
\text { Roskilde, Denmark }\end{array}$ \\
\hline Custos: & $\begin{array}{l}\text { Professor Marja-Liisa Riekkola } \\
\text { University of Helsinki } \\
\text { Department of Chemistry } \\
\text { Helsinki, Finland }\end{array}$ \\
\hline
\end{tabular}


Published by

Finnish Meteorological Institute

(Erik Palménin aukio 1), P.O. Box 503

FIN-00101 Helsinki, Finland
Series title, number and report code of publication Finnish Meteorological Institute Contributions No. 164, FMI-CONT-164

Date: October 2020

\section{Author}

Katriina Kyllönen

Title

Fluxes, trends and source characterisation of atmospheric trace elements

\section{Abstract}

Aerosols are well known to have effects on climate and human health. The chemical composition of aerosols in particular has a profound effect on the latter. Many trace elements (e.g. cadmium, lead and arsenic) found in the particulates as well as mercury (existing mostly in the gaseous form) are considered toxic for humans while deposition of these elements poses risks to the ecosystems. Due to emission abatement strategies, emissions of trace elements have significantly reduced in the recent decades.

The overall objective of this thesis was to gain knowledge on the different sources as well as the temporal and spatial changes of atmospheric trace elements in Finland. The thesis was focused on the priority trace element pollutants mercury, arsenic, cadmium, nickel and lead. Also, other elements of interest were studied (aluminium, chromium, cobalt, copper, iron, manganese, vanadium, and zinc). Gaseous, particulate and deposition forms of the elements were investigated. The work was concentrated in background areas far away from possible anthropogenic sources; however, urban and industrial sites were also surveyed. The measurement techniques were partially developed or further validated in this thesis, and partially we utilised measurements conducted as a part of international measurement programmes.

Sources of trace elements were studied with source apportionment method using positive matrix factorisation (PMF) and enrichment factors. Enrichment factors were used to characterize the source of a pollutant between natural and anthropogenic, and this grouped the elements from mainly crustal ( $\mathrm{Al}, \mathrm{Fe}$ ) to highly anthropogenic origin ( $\mathrm{As}, \mathrm{Cd}, \mathrm{Pb}, \mathrm{Zn}$ ) and others in between. PMF produced a more precise analysis of sources for Pallas, in which trace elements were associated with soil, sea emissions, and various long-range transported sources e.g. copper and nickel smelters in Kola Peninsula, Russia. In addition, magnitude of mercury soil and wetland emissions was investigated at one background site with the chamber technique. The air-terrestrial surface exchange measurements of elemental mercury showed that the soil emissions were found similar to depositional fluxes at the site (but opposite) and larger than the ones observed at wetland.

For most trace elements, a clear south-to-north decreasing gradient in both atmospheric concentrations and deposition was observed due to minor local sources and longer distance to the large European source areas in the north than in the south. Additionally, the differences in the length of the snow-cover period have an effect on resuspension of some of the elements. For several elements both in particulate matter (PM) and deposition, statistically significant decreasing trends up to $80 \%$ were detected since the 1990s. For gaseous mercury, no statistically significant trends were found. No statistically significant increasing trends were observed for PM, however, at two sites increases in deposition of single elements were detected.

\begin{tabular}{|c|c|}
\hline \multicolumn{2}{|c|}{$\begin{array}{l}\text { Publishing unit } \\
\text { Finnish Meteorological Institute, Atmospheric Composition Research }\end{array}$} \\
\hline Classification (UDC) & Keywords \\
\hline $\begin{array}{l}502.3,504.5,543.2 \\
543.5,543.6,551.510 .42\end{array}$ & $\begin{array}{l}\text { Chemical composition, trace elements, heavy metals, PM10, deposition, mercury, } \\
\text { measurements, monitoring, moving platform, chamber method, atmosphere }\end{array}$ \\
\hline $\begin{array}{l}\text { ISSN and series title } \\
0782-6117\end{array}$ & Finnish Meteorological Institute Contributions \\
\hline ISBN & Language Pages \\
\hline $\begin{array}{l}\text { 978-952-336-103-4 (paperback) } \\
\text { 978-952-336-104-1 (pdf) }\end{array}$ & English \\
\hline
\end{tabular}


ILMATIETEEN LAITOS

METEOROLOGISKA INSTITUTET

FINNISH METEOROLOGICAL INSTITUTE

Julkaisija IImatieteen laitos

(Erik Palménin aukio 1), PL 503

00101 Helsinki
Julkaisun sarja, numero ja raporttikoodi

Finnish Meteorological Institute Contributions

Nro. 164, FMI-CONT-164

Julkaisuaika: Lokakuu 2020

Tekijä

Katriina Kyllönen

Nimeke

IImakehän raskasmetallien trendit ja lähteiden karakterisointi

Tiivistelmä

IImakehän hiukkasilla on tunnetusti vaikutuksia ilmastoon ja ihmisten terveydelle. Erityisesti näiden hiukkasten kemiallinen koostumus vaikuttaa jälkimmäiseen. Monien ilmakehässäkin esiintyvien raskasmetallien (kuten elohopean, kadmiumin ja lyijyn) tiedetään olevan myrkyllisiä ihmiselle, kun taas näiden laskeuma aiheuttaa haittaa ekosysteemeille. Päästövähennystoimenpiteiden myötä raskasmetallien päästöt ovat yleisesti vähentyneet viime vuosikymmeninä.

Tämän väitöskirjan yleisenä tavoitteena oli selvittää ilmakehän raskasmetallien lähteitä sekä ajallisia ja maantieteellisiä trendejä Suomessa. Tutkimus keskittyi erityisen haitallisiin alkuaineisiin elohopeaan, arseeniin, kadmiumiin, nikkeliin ja lyijyyn. Myös alumiini, koboltti, kromi, kupari, mangaani, rauta, sinkki ja vanadiini olivat selvityksen kohteena. Väitöskirjassa on tutkittu näiden esiintymistä kaasumaisena, hiukkasiin sitoutuneena ja laskeumassa keskittyen kaukana päästölähteitä sijaitseviin tausta-alueisiin. Myös kaupunki- ja teollisuusympäristöt olivat kohteena. Tutkimuksessa käytettiin itse kehitettyjä tai validoituja mittausjärjestelmiä sekä kansainvälisissä mittausohjelmissa kerättyä tietoa.

Raskasmetallien lähteitä tutkittiin kahdella lähdeanalyysillä. Rikastumiskertoimilla metallit jaettiin luonnosta ja ihmistoiminnasta peräisiin, ja analyysin perusteella suurin osa metalleista oli selvästi peräisin antropogeenisistä lähteistä, kun taas muutamat maaperän pölyämisestä. Yhdellä mittausasemista (Pallas) tutkittiin tarkemmin lähteitä positiivisen matriisin faktoroinnilla (PMF), jonka perusteella raskasmetallien lähteiksi tunnistettiin maaperän pölyäminen, meri, sekä erilaisia kaukokulkeumana vaikuttavia lähteitä, kuten kupari-nikkelisulatot Kuolan niemimaalla. Lisäksi elohopeatasetta tutkittiin ilmakehän ja maaperän/suon välillä kammiomenetelmällä yhdellä eteläisistä tausta-asemista. Tutkimuksessa havaittiin, että elohopeaa haihtui enemmän metsämaasta kuin suolta, ja metsämaasta haihtunut elohopean määrä vastasi karkeasti maahan laskeuman mukana kertynyttä osuutta.

Useimpien raskasmetallien ilmapitoisuudet ja laskeuma kohosivat pohjoisesta etelään päin johtuen eroista paikallisissa päästöissä sekä pidemmästä etäisyydestä Euroopan suuriin päästöalueisiin. Myös etelän pohjoista lyhyempi lumikausi vaikutti joidenkin metallien pitoisuuksiin kohottavasti. Useimpien raskasmetallien ilmapitoisuuksien ja laskeuman todettiin vähentyneen tilastollisesti merkitsevästi, enimmillään 80 \% 1990-luvun lopusta vuoteen 2018. Sen sijaan kaasumaisen elohopean pitoisuuksissa ei havaittu tilastollisesti merkitseviä muutoksia. Tilastollisesti merkitsevää ilmapitoisuuden nousua ei havaittu millään tutkituista metalleista pohjoisella mittausasemalla; sen sijaan laskeuman osalta kahdella mittausasemalla havaittiin yksittäisten alkuaineiden nousua.

\section{Julkaisijayksikkö}

IImatieteen laitos, IImakehän koostumuksen tutkimus

\begin{tabular}{|c|c|c|}
\hline Luokitus (UDK) & \multicolumn{2}{|c|}{ Asiasanat } \\
\hline $\begin{array}{l}502.3,504.5,543.2 \\
543.5,543.6,551.510 .42\end{array}$ & \multicolumn{2}{|c|}{$\begin{array}{l}\text { Kemiallinen koostumus, hivenalkuaineet, raskasmetallit, PM10, laskeuma, elohopea, } \\
\text { mittaukset, seuranta, liikkuvat mittaukset, kammiomenetelmä, ilmakehä }\end{array}$} \\
\hline \multicolumn{3}{|l|}{ ISSN ja avainnimeke } \\
\hline $0782-6117$ & \multicolumn{2}{|c|}{ Finnish Meteorological Institute Contributions } \\
\hline ISBN & Kieli & Sivumäärä \\
\hline $\begin{array}{l}\text { 978-952-336-103-4 (nidottu) } \\
\text { 978-952-336-104-1 (pdf) }\end{array}$ & englanti & 62 \\
\hline
\end{tabular}




\section{Acknowledgements}

The research of this thesis was carried out at the Air Quality Department and Atmospheric Composition Research of the Finnish Meteorological Institute.

For the opportunity to work at FMI, I warmly thank the former and current Heads of the Unit Professors Yrjö Viisanen, Jaakko Kukkonen, Docent Heikki Lihavainen and most of all Professor Hannele Hakola who has also acted as my supervisor in this thesis and group leader in earlier years. Hannele, special thanks for believing this thesis will ultimately be completed and giving the push to do it. (I must say it is ironic that when it was finally(!!) ready a worldwide pandemia postponed it even further.) Docent Jussi Paatero and Licentiate Vuokko Karlsson, you are the ones to thank that I first started my adventures in atmospheric research as you hired me in the first place back in 2003. Jussi, you have guided me in my early years of science and enabled me to start to work on this thesis, and Vuokko, you have also been my mentor on other parts of my FMI career including lab work and quality issues. I wish to deeply thank my current group leader Docent Heidi Hellén for the support, conversations and friendship over the years. Professor Marja-Liisa Riekkola at the Department of Chemistry at Helsinki University is kindly thanked for getting me interested in analytical chemistry as a Master student, introducing me to FMI by a summer trainee programme and finally for supporting my postgraduate studies.

My sincere thanks to the official Reviewers of the thesis manuscript, Professor Paavo Perämäki (University of Oulu) and Docent Jorma Joutsensaari (University of Eastern Finland), for reviewing and commenting my work. I highly appreciate that Prof. Henrik Skov from the Aarhus University has kindly promised to be my official opponent in the public examination of this thesis.

I would like to thank all my co-authors for the fruitful discussions, input and improvements for my work. The people assisting in the field trips (Jussi, Heidi, Mika, Timo, Ari, Matti V., Mirja and others) and in the lab (especially Ulla, Anne, Janne), these articles would not have realised without your help. The field trips have been memorable journeys and sources of many laughter and inside jokes afterwards. I also feel lucky to have such amazing colleagues, thanks for all of you for the enjoyable moments in the lab, coffee and lunch tables, and outside the office.

My dear friends Hanna and Sanna, genuine thanks for starting the chemistry road with me and leading my way to analytical chemistry in your footsteps and moreover for all the precious moments outside academia. Typyt, Ressut, Posse, the extended Hiiska, other friends and relatives, many thanks for the good company, fun memories and support over the years.

Finally, my warmest gratitude is expressed to my family. My parents Hilkka and Markku, thanks for always believing me and for your endless support. My brother Lauri, thanks for the fruitful rehearsals for the dissertation day :) My dear husband Juha, your support and flexibility during the years has been amazing. Last, my most precious darlings Annika and Anton, you are my joy, my inspiration, and my everything.

Helsinki, 16.9.2020

Katriina Kyllönen 


\section{ABBREVIATIONS AND DEFINITIONS}

AAS

AFS

Al

AMAP

AMDE

As

$\mathrm{BrO}$

$\mathrm{Ca}$

$\mathrm{Cd}$

CEN

CFC

$\mathrm{Cl}$

Co

$\mathrm{Cr}$

CRM

$\mathrm{Cu}$

CV-AFS

EC

EF

EMEP

EN

$\mathrm{Fe}$

FMI

GAW

GDAS

GLS-ARMA

GMOS

GOM

GOS4M
Atomic absorption spectrometer/spectrometry

Atomic fluorescence spectrometer/spectrometry

Aluminium

Arctic Monitoring and Assessment Programme

Atmospheric mercury depletion event

Arsenic

Bromine oxide

Calcium

Cadmium

European Committee for Standardization

Chlorofluorocarbon/-s

Chlorine

Cobalt

Chromium

Certified reference material

Copper

Cold vapor atomic fluorescence spectrometer/spectrometry

Elemental carbon, or European Commission

Enrichment factor

The co-operative programme for monitoring and evaluation of the long-range transmission of air pollutants in Europe, also known as European Monitoring and Evaluation Programme

European standard

Iron

Finnish Meteorological Institute

WMO Global Atmosphere Watch

Global data assimilation system

Generalized least squares regression with autoregressive moving average

Global Mercury Observation System

Gaseous oxidised mercury (also referred as RGM)

Global Observation System for Mercury 


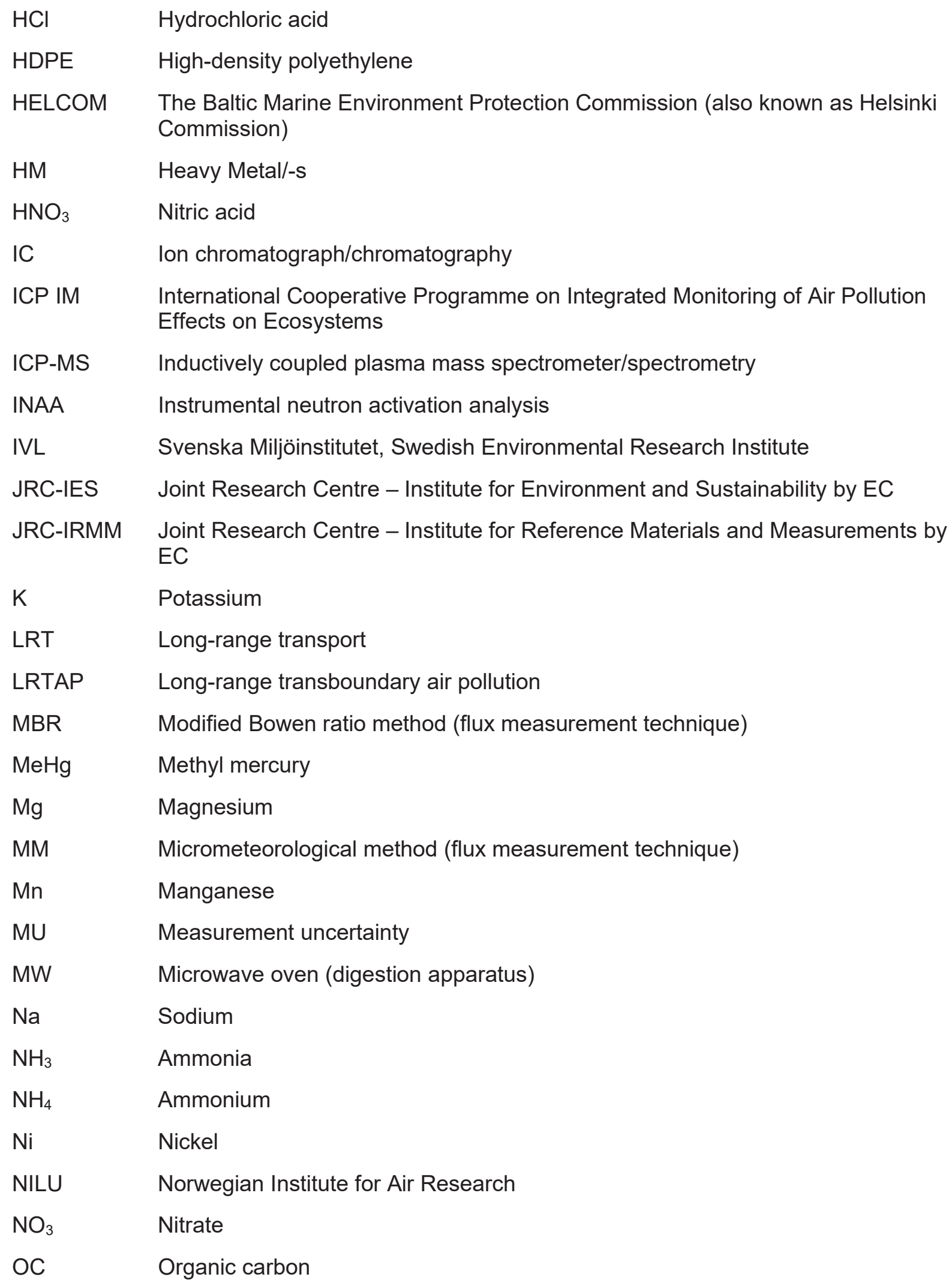


PAH Polycyclic aromatic hydrocarbon/-s

$\mathrm{Pb} \quad$ Lead

PIXE Proton induced X-ray emission spectrometry

PM Particulate matter

$\mathrm{PM}_{10} \quad$ Particles with a diameter of $10 \mu \mathrm{m}$ or less $(\mathrm{Dp} \leq 10 \mu \mathrm{m})$

$\mathrm{PM}_{2.5} \quad$ Particles with a diameter of $2.5 \mu \mathrm{m}$ or less $(\mathrm{Dp} \leq 2.5 \mu \mathrm{m})$

PMF Positive matrix factorization

PSCF Potential source contribution function

PTFE Polytetrafluoroethylene (Teflon)

QC Quality control

REA Relaxed eddy accumulation (flux measurement technique)

RGM Reactive gaseous mercury (also referred as GOM)

RSD Relative standard deviation

SMEAR Station for Measuring Forest Ecosystem-Atmosphere Relations

$\mathrm{SO}_{2} \quad$ Sulphur dioxide

$\mathrm{SO}_{4} \quad$ Sulphate

SRM Standard reference material

SYKE Suomen Ympäristökeskus, Finnish Environment Institute

TE Trace element/-s

TGM Total gaseous mercury

TS Trend significance

TSP Total suspended particles

UNECE United Nations Economic Commission for Europe

UNEP United Nations Environment Programme

US-EPA United States Environmental Protection Agency

V Vanadium

VOC Volatile organic compound/-s

WHO World Health Organization

WMO World Meteorological Organization

Zn Zinc

XRF X-ray fluorescence 


\section{Contents}

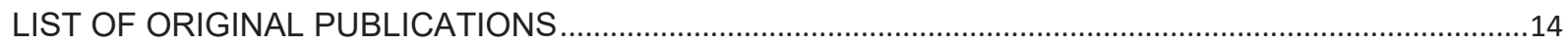

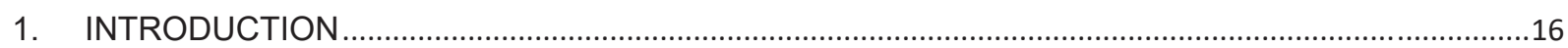

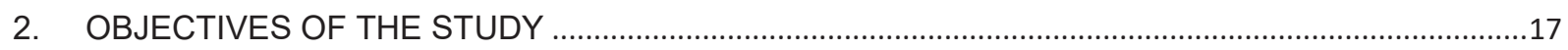

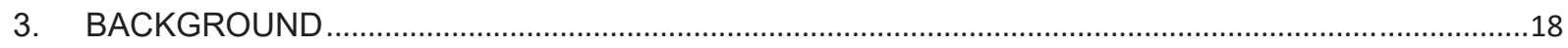

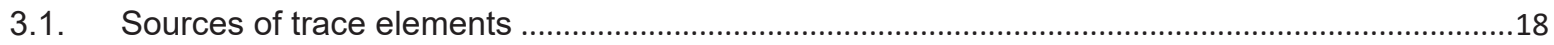

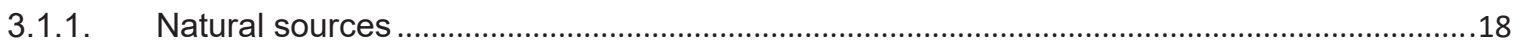

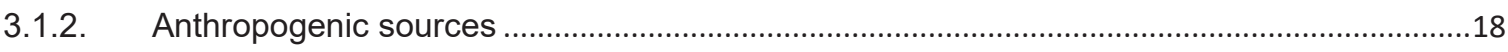

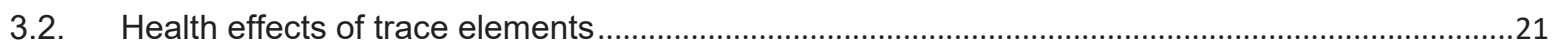

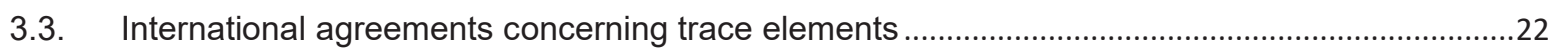

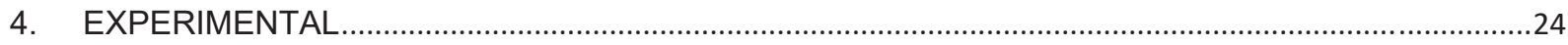

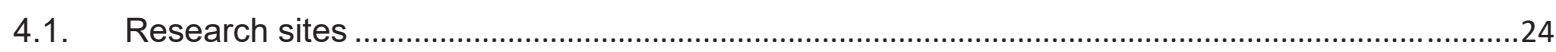

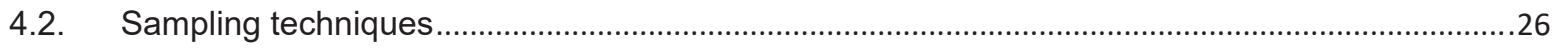

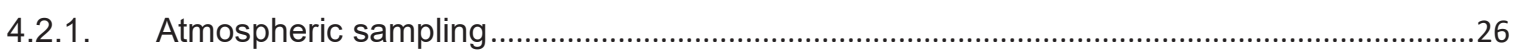

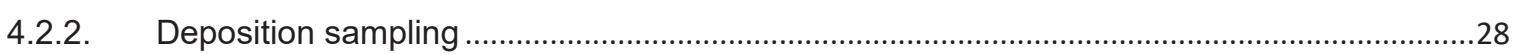

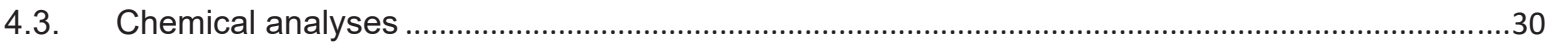

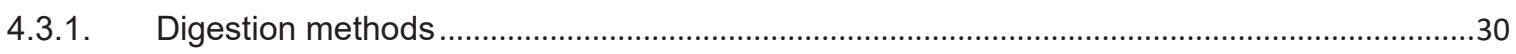

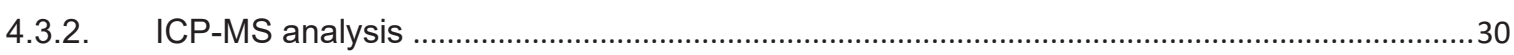

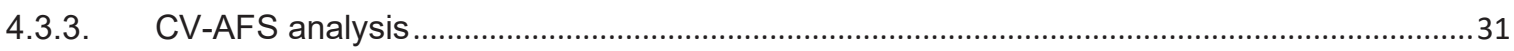

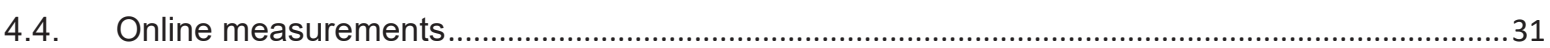

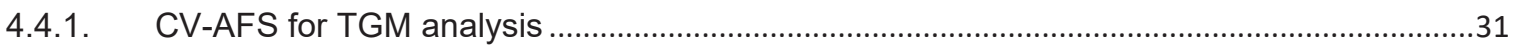

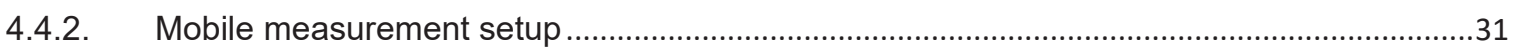

4.5. Flux measurements for studying air-terrestrial surface exchange ..............................................32

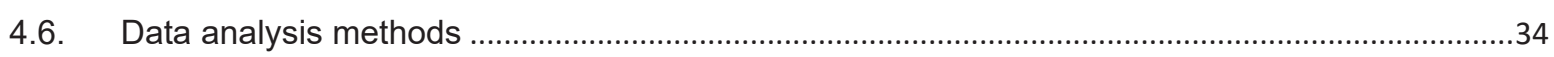

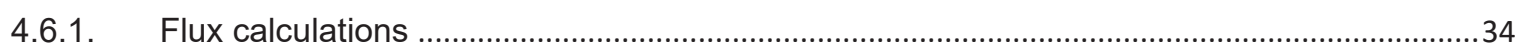

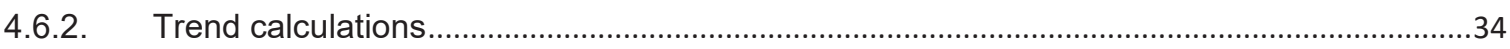

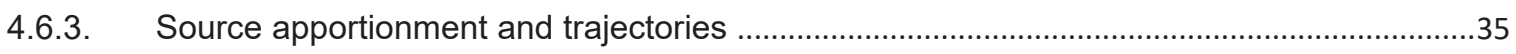

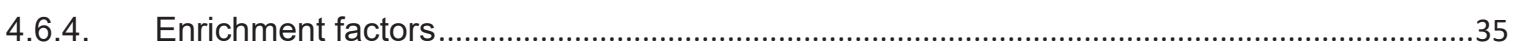

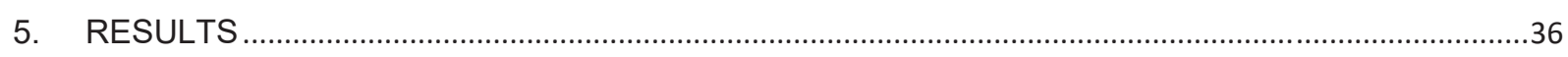

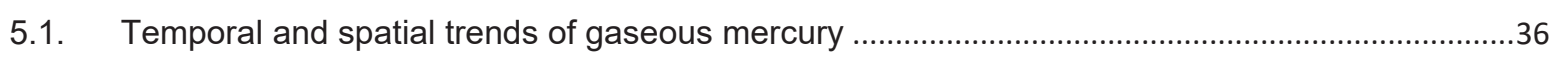

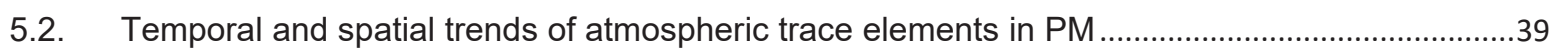

5.3. Temporal and spatial trends of trace element deposition .............................................................43

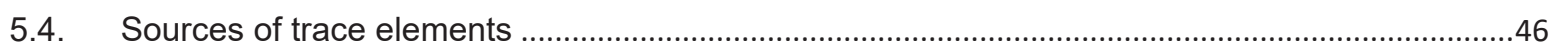

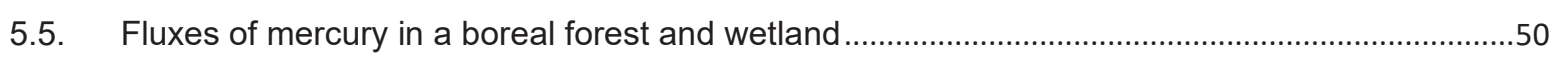

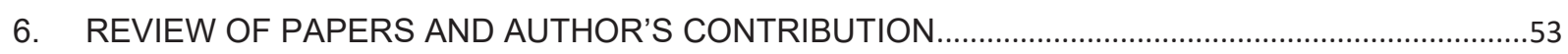

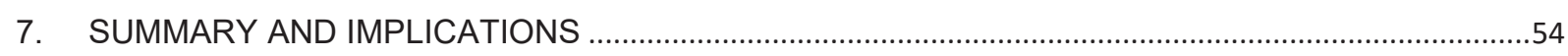

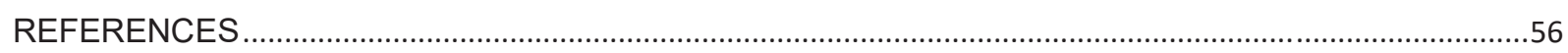




\section{LIST OF ORIGINAL PUBLICATIONS}

This thesis consists of an introductory review part, followed by five original research articles.

The papers are reproduced with the kind permission of the journals concerned. The references to the articles are indicated in the text by their Roman numerals.

I Kyllönen K., Paatero J., Aalto T., Hakola H. (2014) Nationwide survey of airborne mercury in Finland. Boreal Environment Research, 19B, 355-367.

II Kyllönen K., Hakola H., Hellén H., Korhonen M., Verta M. (2012) Atmospheric mercury fluxes in southern boreal forest and wetland. Water, Air and Soil Pollution, 223, 11711182.

III Kyllönen K., Vestenius M., Anttila P., Makkonen U., Aurela M., Wängberg I., Nerentorp Mastromonaco M., Hakola H. (2020) Trends and source apportionment of atmospheric heavy metals at a sub-arctic site during 1996-2018. Submitted to Atmospheric Environment.

IV Kyllönen K., Karlsson V., Ruoho-Airola T. (2009) Trace element deposition and trends during a ten year period in Finland. Science of Total Environment, 407, 2260-2269.

V Ruoho-Airola T., Hatakka T., Kyllönen K., Makkonen U., Porvari P. (2013) Temporal trends in the bulk deposition and atmospheric concentration of acidifying compounds and trace elements in the Finnish Integrated Monitoring catchment Valkea-Kotinen during 1988-2011. Boreal Environment Research, 19A, 31-46. 


\section{Other publications of the author not included in the thesis}

Jiskra M., Sonke J.E., Obrist D., Bieser J., Ebinghaus R., Lund Myhre C., Aspmo Pfaffhuber K., Wängberg I., Kyllönen K., Worthy D., Martin L.G., Labuschagne C., Mkololo T., Ramonet M., Magand O. and Dommergue A. (2018) A vegetation control on seasonal variations in global atmospheric mercury concentrations. Nature Geoscience, 11, 244-250.

Lohila A., Penttilä T., Jortikka S., Aalto T., Anttila P., Asmi E., Aurela M., Hatakka J., Hellén H., Henttonen H., Hänninen P., Kilkki J., Kyllönen K., Laurila T., Lepistö A., Lihavainen H., Makkonen U., Paatero J., Rask M., Sutinen R., Tuovinen J.-P., Vuorenmaa J. and Viisanen Y. (2015) Preface to the special issue on integrated research of atmosphere, ecosystems and environment at Pallas. Boreal Env. Res., 20, 431-454.

Vestenius M., Leppänen S., Anttila P., Kyllönen K., Hatakka J., Hellén H., Hyvärinen A. and Hakola H. (2011) Background concentrations and source apportionment of polycyclic aromatic hydrocarbons in South-Eastern Finland. Atmospheric Environment, 45, 3391-3399.

Paatero J., Vesterbacka K., Makkonen U., Kyllönen K., Hellen H., Hatakka J. and Anttila P. (2009) Resuspension of radionuclides into the atmosphere due to forest fires. J. Radioanal. Nucl. Chem., 282, 473-476.

Anttila P., Makkonen U., Hellén H., Kyllönen K., Leppänen S., Saari H. and Hakola H. (2008) Impact of the open biomass fires in spring and summer of 2006 on the chemical composition of background air in south-eastern Finland. Atmospheric Environment, 42, 6472-6486.

Kuokka S., Teinilä K., Saarnio K., Aurela M., Sillanpää M., Hillamo R., Kerminen V.M., Pyy K., Vartiainen E., Kulmala M., Skorokhod A.I., Elansky N.F. and Belikov I.B. (2007) Using a moving measurement platform for determining the chemical composition of atmospheric aerosols between Moscow and Vladivostok. Atmos. Chem. Phys., 7, 4793-4805.

Karlsson V., Pyy K. and Saari H. (2007) Measurement uncertainty of sulphur and nitrogen containing inorganic compounds by 1 -stage and 2-stage filter-pack methods. Water, Air, \& Soil Pollution, 182, 395-405. 


\section{INTRODUCTION}

"No sooner had I left behind the oppressive atmosphere of the city [Rome] and that reek of smoking cookers which pour out, along with clouds of ashes, all the poisonous fumes they've accumulated in their interiors whenever they're started up, than I noticed the change in my condition." -Seneca the Younger, a philosopher, statesman and adviser to Emperor Nero in 61 $A D$.

Air pollution has been recognized as a health concern already in ancient times. In 535AD, the Emperor Justinian I regulated in a Roman law: "By the law of nature these things are common to mankind - the air, running water, the sea." During the industrial revolution, the magnitude of the air pollution problem rose to new extensions. Today, an estimated 4 million lives are lost annually as a consequence of ambient air pollution exposure, and air pollution has been recognized as the world's largest single environmental health risk (Lelieveld et al., 2015; PrüssUstün et al., 2016; WHO, 2018). Air pollutants are emitted from a range of sources, including both natural and man-made, e.g. burning of fossil fuel (Fig. 1), industrial processes and traffic.

Health organisations and regulatory bodies have set up limit, target and guidance values to lower the air pollution. Moreover, bans to use certain substances, e.g. chlorofluorocarbons (CFCs) in refrigerants and other products, and lead as an additive in gasoline, have had remarkable effect on the climate and the air pollution. The success story of the declined ambient $\mathrm{Pb}$ concentrations is one positive example of the power of such international acts; a decline also confirmed in this thesis.

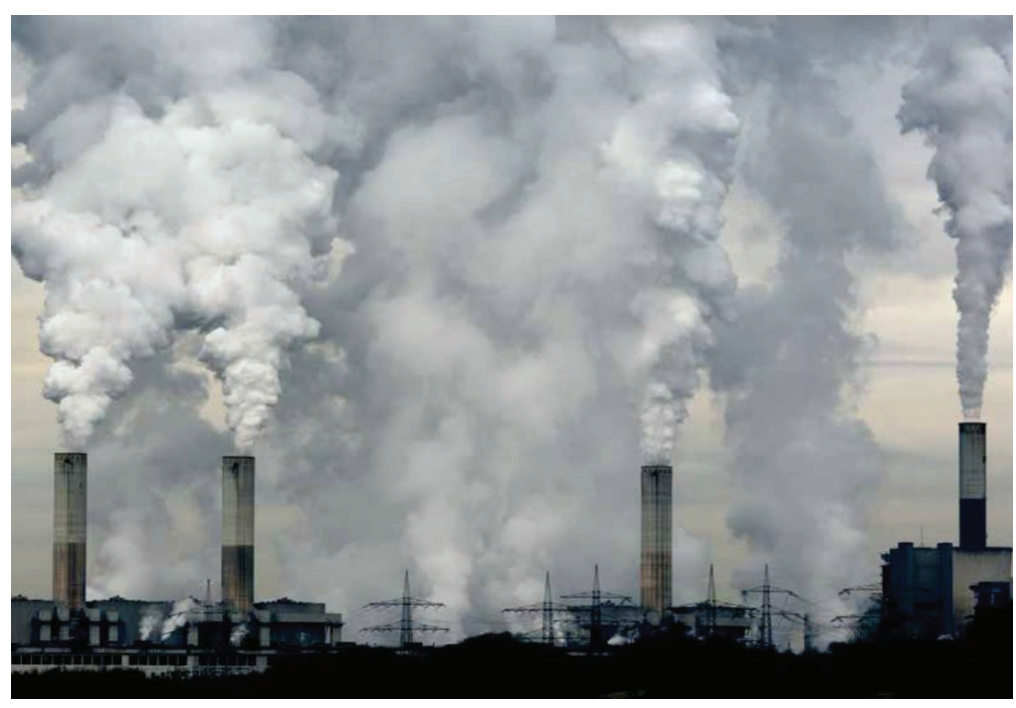

Fig. 1. A coal-fired power plant contributing to ambient air pollution (adopted from Prüss-Ustün et al., 2016).

This thesis is focused on atmospheric trace elements, namely aluminium (Al), arsenic (As), cadmium (Cd), chromium ( $\mathrm{Cr})$, cobalt $(\mathrm{Co})$, copper $(\mathrm{Cu})$, iron $(\mathrm{Fe})$, lead $(\mathrm{Pb})$, manganese $(\mathrm{Mn})$, 
mercury $(\mathrm{Hg})$, nickel $(\mathrm{Ni})$, vanadium $(\mathrm{V})$, and zinc $(\mathrm{Zn})$. The term trace elements reflects the presence of these elements in trace concentrations in various environmental matrices. Often, they are called heavy metals as they have rather high atomic masses and high density, however, this term has never been defined by any authoritative body and there is no consensus about the use of it (Duffus, 2002). The use can be misleading, as e.g., arsenic is categorized as a semi-metal, and aluminium is rather light with an atomic mass of 26.98 and density of $2.7 \mathrm{~g}$ $\mathrm{cm}^{-3}$. Thus, the term trace elements is used throughout this thesis summary report to describe all the elements studied.

The thesis presents campaign studies and measurements of atmospheric trace elements conducted mainly in different background areas but also in urban and industrial areas in Finland. Part of the techniques were developed and further validated in this thesis and partially we utilised measurements conducted as a part of international measurement programmes. The research was conducted to enhance our knowledge of the fluxes and sources of atmospheric trace elements. Additionally, temporal and spatial trends were studied to improve our understanding on the effect of reduced anthropogenic emissions.

\section{OBJECTIVES OF THE STUDY}

Due to emission abatement strategies, emissions of several heavy metals have decreased over the years. The overall aim of this thesis was to explore whether the reductions have been effective in reducing ambient air concentrations and deposition and which are the actual sources of trace elements in Finland. The more specific objectives of the thesis were:

- To study deposition (Papers II, IV, V) and atmospheric concentrations of trace elements in rural areas (Papers I-III, V) as well as urban and industrial areas (Paper I);

- To investigate the temporal and spatial trends of atmospheric trace elements at a number of locations around Finland (Papers I, III-V);

- To explore the specific sources of trace elements (Papers I-IV);

- To develop a flux chamber methodology to estimate the air-terrestrial surface exchange in a boreal forest and wetland (Paper II) and further validate measurement techniques utilized in atmospheric studies of trace elements (Papers I, II and IV). 


\section{BACKGROUND}

Atmospheric trace elements are mainly associated with the particulate matter (PM) with the exception of $\mathrm{Hg}$, which exists mainly in the gaseous form. Many of them are highly toxic and considered known or potential carcinogens.

To assess the environmental risks, it is necessary to identify the source of the pollutants. Atmospheric trace elements have several sources with both natural and anthropogenic (i.e. manmade) origin. The share between these two variates largely depending on the element as does the source categories between them. Moreover, the distribution of domestic anthropogenic emissions can be different to the global distribution of sources. For example, small scale artisanal goldmining is currently recognised globally as the biggest anthropogenic source for $\mathrm{Hg}$ while the technique is not used in Finland nor in Europe (EU28) and these regions have zero emissions in this category (AMAP/UN Environment, 2019).

\subsection{Sources of trace elements}

\subsubsection{Natural sources}

Wind-borne soil particles, volcanoes, biogenic sources (e.g. non-sea salt marine), wild forest fires and sea salt spray are recognized as the principal natural sources for trace elements (Nriagu, 1989). Soil-derived dust has been estimated as the main natural source for Co, $\mathrm{Cr}, \mathrm{Mn}$, $\mathrm{Pb}, \mathrm{V}$, and $\mathrm{Zn}$, while volcanoes have been evaluated as the principal for $\mathrm{As}, \mathrm{Cd}, \mathrm{Cu}$, and $\mathrm{Ni}$.

For $\mathrm{Hg}$, evasion from oceans has been identified as the primary source while others include e.g. biomass burning and emissions from the vegetated and non-vegetated surfaces (Pirrone et al., 2010). Existing mostly in gaseous form, previously deposited $\mathrm{Hg}$ can be re-emitted from water and terrestrial surfaces making it difficult to distinguish between primary emissions from secondary re-emissions (AMAP/UNEP, 2008). Furthermore, it has been under debate whether the terrestrial surfaces and certain ocean areas are actually sources or sinks of $\mathrm{Hg}$ (Agnan et al., 2016; Dastoor and Durnford, 2014).

\subsubsection{Anthropogenic sources}

The anthropogenic sources of atmospheric trace elements vary significantly, however, many of them are released by high temperature processes. Stationary fossil fuel combustion has been considered as the main emission source for As, Cd, Cr, Hg, Mn, Ni and V (Pacyna and Pacyna, 2001; Pacyna et al., 2007; Pacyna et al., 2010).

Combustion of coal in particular releases trace elements. Eventhough the concentration of e.g. $\mathrm{Hg}$ is low in coal, it still dominates as a source as the amount of coal used for combustion is so large and the emissions go straight to the atmosphere (Pacyna et al., 2010). However, in a recent global assessment (AMAP/UN Environment, 2019), artisanal and small-scale gold mining was estimated as the main source for $\mathrm{Hg}$ globally while for Europe (EU28) and North America fuel combustion followed with industry sectors remained the largest sources. 
For $\mathrm{Ni}$ and $\mathrm{V}$, combustion of oil has been identified as the main source (Pacyna and Pacyna, 2001). Moreover, metal industry has been found a significant source for $\mathrm{As}, \mathrm{Cd}, \mathrm{Cu}$, and $\mathrm{Zn}$ (EEA, 2019a; Pacyna and Pacyna, 2001).

For $\mathrm{Pb}$, the use of leaded gasoline was traditionally identified as the main source (Pacyna et al., 2007 ) but today it is no longer used as an additive in EU. However, road transport with a $17 \%$ share (in 2017) remains a significant source in Europe (EEA, 2019a). The car tyre and break wear is currently reported as the single main $\mathrm{Pb}$ source in Europe. Furthermore, the combustion of unleaded gasoline produces $\mathrm{Pb}$ emissions as it exits as an impurity in the fuel due to the $\mathrm{Pb}$ content in the crude oil; also engine lubricants and parts generate $\mathrm{Pb}$ emissions.

In Finland, Finnish Environment Institute reports the annual emissions of atmospheric pollutants, and in the lack of scientific publications, data available in their web pages were used below for the analysis of domestic emissions (Finnish Environment Institute, 2020).

Nationally, energy production is the main emission category (51-90\%) for all the reported trace elements except for copper (Fig. 2). Within the energy field, production for industrial use and for public electricity and heating are the main subcategories. For zinc, energy production for households is the main subcategory.

Industrial processes is the second largest main category with the exception of copper and zinc. For e.g. $\mathrm{Hg}$, iron and steel industry as well as inorganic chemical industry are the main subcategories.

Traffic is the main emission category reported for copper in Finland. However, the most of traffic emissions are not due to fuels, instead, the tyre and brake wear are the main subcategories reported for most elements. For the others, namely cadmium, mercury and nickel, the main subcategories are industrial transport, passenger cars and marine transport, respectively.

The atmospheric emissions of all trace elements have decreased in Finland since 1990 as illustrated in Fig. 3 (data adopted from Finnish Environment Institute, 2020). Comparing the values for 1990 and 2017, the reduction has been between $47 \%(\mathrm{Hg})$ and $95 \%(\mathrm{~Pb})$. The decrease has been rather systematic for all elements except mercury that has experienced decrease in 1990s, increase in early 2000s and again decrease after 2006 according to the official reported emissions. 
As

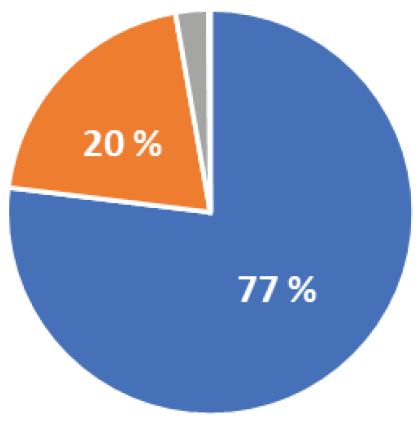

$\mathrm{Cu}$

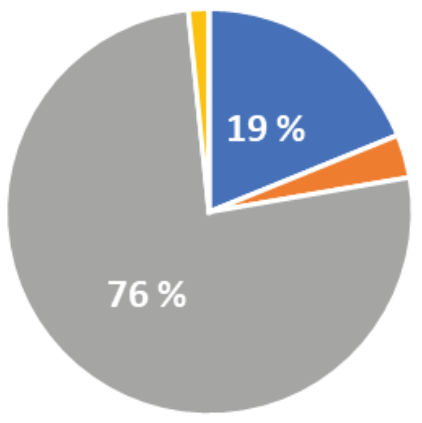

$\mathrm{Pb}$
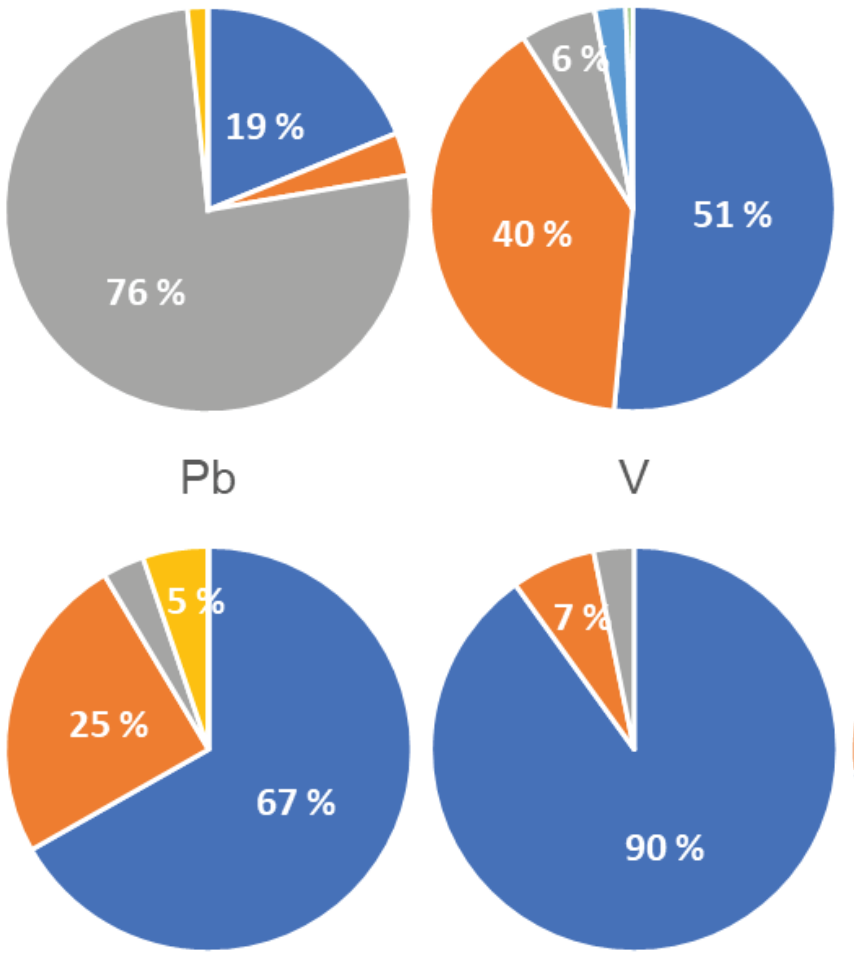

$\mathrm{Hg}$

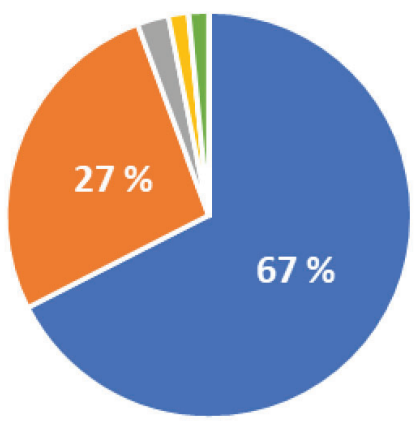

$\mathrm{Ni}$
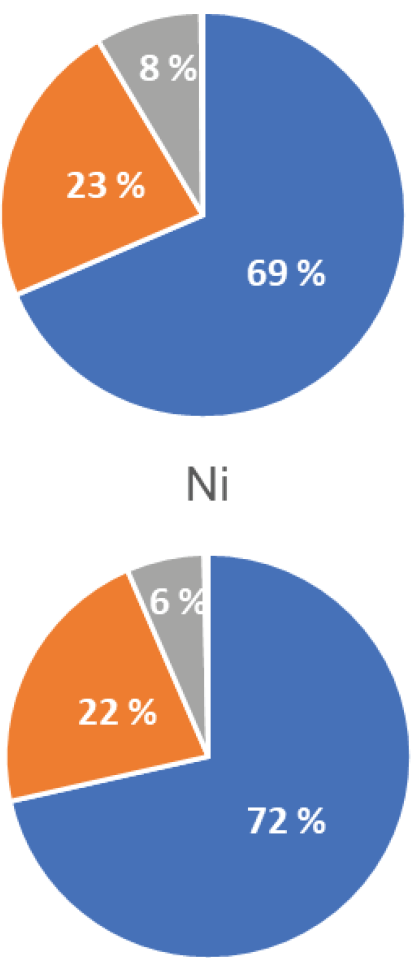

$\mathrm{Zn}$

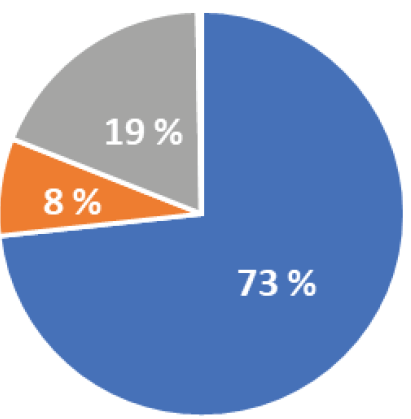
- Energy production Industrial processes
n Traffic
- Product use
- Waste management - Agricultural

Fig. 2. The reported emission sources of trace elements in Finland in 2017 (adopted from Finnish Environment Institute, 2020). 

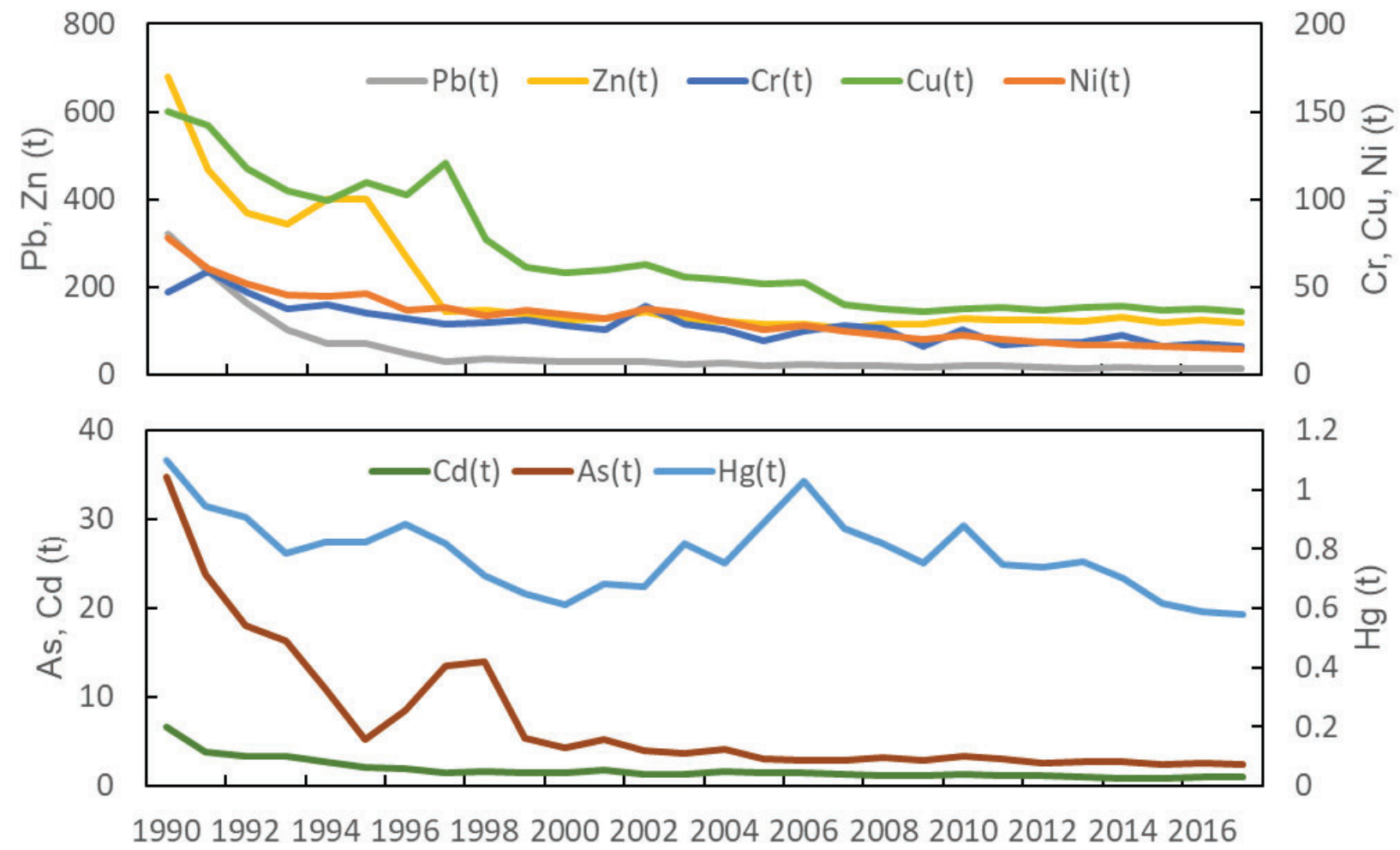

Fig. 3. The reported emissions of trace elements (in tons) in Finland in 1990-2017 (adopted from Finnish Environment Institute, 2020).

\subsection{Health effects of trace elements}

Aerosols are well known to cause negative health effects. Many trace elements are considered toxic and have no established biological functions (Tchounwou et al., 2012). As they are occurring naturally, they are found throughout the earth's crust. Anthropogenic activities have released these elements to the atmosphere since the preindustrial era. As stated for $\mathrm{Hg}$, all people are exposed to some amount of this toxic element (UNEP, 2018); this is also true for the other elements studied in this thesis.

The health problems include cancer and cardiovascular diseases among many other unwanted effects and illnesses. The effect of the toxicity of the element depends on multiple factors including e.g. the age and gender of the person as well as route of exposure and the dose (Tchounwou et al., 2012). It has been stated that even low concentrations cause health problems, however, little is known about the combined health impact of a mixture of the elements. Concurrent exposure to several trace elements may produce additive, antagonistic or synergistic toxic effects.

For some trace elements, the chemical oxidation state determines the toxicity of the element (Suvarapu and Baek, 2017), e.g. $\mathrm{Cr}(\mathrm{VI})$ is highly toxic and considered a human carcinogen while $\mathrm{Cr}(\mathrm{III})$ is used as a micronutrient for its health benefits (Tchounwou et al., 2012) while 
As(III) is considered more toxic than As(V) (Yamauchi and Fowler, 1994). For Hg, the organic species (MeHg in particular) are more toxic than the inorganic species, however, health risks of $\mathrm{Hg}$ are mainly accounted for the chronic $\mathrm{MeHg}$ exposure through consumption of fish (Liu et al., 2012).

\subsection{International agreements concerning trace elements}

Several global and regional treaties have been implemented to lower the emissions of pollutants and ultimately to protect human health. Regarding trace elements, five international agreements have been executed in Finland.

The Convention on the Protection of the Marine Environment of the Baltic Sea Area (Helsinki Convention) is governed by the Baltic Marine Environment Protection Commission (Helsinki Commission - HELCOM). The first convention was signed in 1974 to protect the aquatic environment of the Baltic Sea from pollution through intergovernmental cooperation. Since then, it has been replaced by the 1992 Helsinki Convention that came into force in 2000 (HELCOM, 2014). It has 10 contracting parties that all have a coastal line to the Baltic Sea.

The Convention for the Protection of the Marine Environment of the North-East Atlantic (the OSPAR Convention) was entered in force in 1998 and replaced the Oslo and Paris Conventions. It addresses pollution from land-based, offshore and other sources as well as dumping and incineration. The convention has been ratified by all the 17 contracting parties.

The Convention on Long-range Transboundary Air Pollution (LRTAP) supported the development of the Heavy Metals Protocol under the United Nations Economic Commission for Europe (UNECE). This treaty, named the 1998 Aarhus Protocol on Heavy Metals, addresses three heavy metals (Cd, $\mathrm{Hg}, \mathrm{Pb}$ ) and was signed in 1998 (UNECE, 1998). It came into force in 2003 and has been ratified, accepted, approved or accessed by 34 European and North American countries since (as of January, 2020). Since the initial implementation, a new decision has been adopted by the parties in 2012 to include more stringent controls of heavy metals emissions and to ease the participation of new parties by introducing flexibilities.

In the European Union, the Registration, Evaluation, Authorisation and Restriction of Chemicals (REACH) agreement managed by the EU Environmental Chemicals Agency (ECHA) came into force in 2007. This agreement relates to chemicals and metals management and obliges all producers and importers to register their substances in ECHA.

Finally, the Minamata Convention on Mercury (UN Environment, 2017) is a global treaty, which was adopted in October 2013 and entered into force in August 2017. This was implemented to protect human health and the environment from the adverse effects of mercury. So far it has been signed by 128 countries and ratified by 116 (as of January, 2020). The treaty obligates the signed countries to control measures on $\mathrm{Hg}$ emissions and the release of $\mathrm{Hg}$ to ambient air, water bodies and soil. It bans e.g. the production, import and export of certain $\mathrm{Hg}$ containing products, e.g. specific fluorescent lamps and batteries, and addresses other aspects to reduce Hg use globally. 
Monitoring activities are essential to confirm whether the controls in national, regional and global scale are effective. Several international measurement programmes have been established to monitor pollutants. Those relevant to Finland include:

- AMAP, Arctic Monitoring and Assessment Programme

- EMEP, The European Monitoring and Evaluation Programme

- GAW, Global Atmosphere Watch

- GMOS, Global Mercury Observation System

- GOS4M, Global Observation System for Mercury

- HELCOM, Helsinki Commission monitoring

- ICP IM, International Co-operative Programme on Integrated Monitoring of Air Pollution Effects on Ecosystems 


\section{EXPERIMENTAL}

\subsection{Research sites}

All the measurements and results presented in this thesis haven been conducted in Finland. Altogether 11 sites (Fig. 4) have been included in the studies in addition to the nationwide survey in Paper I. In the nationwide survey, all major population centres and large number of industrial sites were surveyed in addition to traffic environments and rural areas (see Fig. 13 for the measurement route along with measured concentrations).

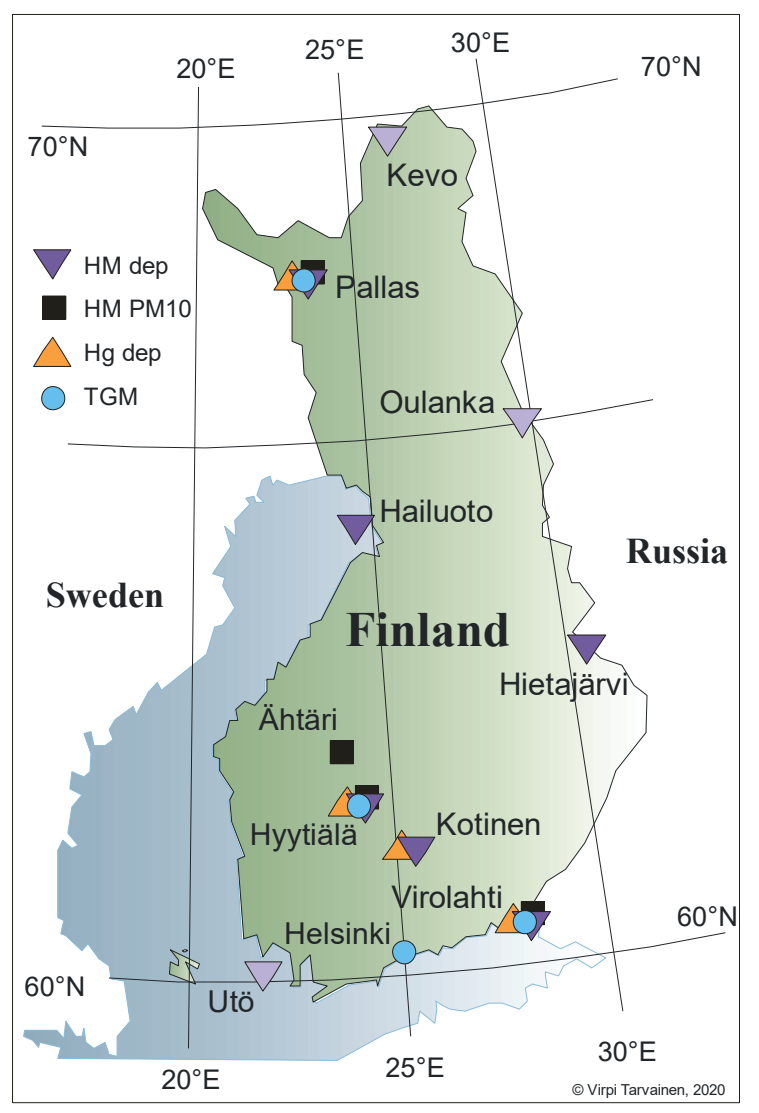

Fig. 4. Locations of measurement and sampling sites used in this thesis (nationwide survey not included). At the sites Utö, Kevo, Oulanka and Ähtäri, the measurements of trace elements have been discontinued. In Helsinki, a one-year study in 2006-2007 was performed.

The thesis is concentrated in background areas (Papers I-V) with the addition of urban and industrial sites included in Paper I (Table 1). Most of the sites used in this study belong to several international measurement programs such as AMAP, EMEP, GMOS/GOS4M, HELCOM, ICP IM, WMO/GAW and SMEAR. The thesis consists of long-term studies utilizing 
Table 1. Measurement sites, periods and sample types used in this thesis.

\begin{tabular}{|c|c|c|c|c|}
\hline Site location & Site type & Sample type & $\begin{array}{l}\text { Measurement } \\
\text { period }\end{array}$ & Paper \\
\hline Helsinki, Isosaari & $\begin{array}{l}\text { Urban } \\
\text { background } \\
\text { (marine) }\end{array}$ & Ambient air & 09/2006-08/2007 & I \\
\hline Several sites* & $\begin{array}{l}\text { Urban, traffic, } \\
\text { industrial, rural }\end{array}$ & Ambient air & 09-10/2007 & I \\
\hline $\begin{array}{l}\text { Valkea-Kotinen } \\
\text { (ICP IM) }\end{array}$ & $\begin{array}{l}\text { Rural } \\
\text { background } \\
\text { (boreal forest and } \\
\text { wetland) }\end{array}$ & $\begin{array}{l}\text { Flux } \\
\text { Ambient air } \\
\text { Deposition } \\
\text { Deposition } \\
\text { Deposition }\end{array}$ & $\begin{array}{l}04-09 / 2007 \\
08 / 2007 \\
01-12 / 2007 \\
1998-2007 \\
1988-2011\end{array}$ & $\begin{array}{l}\text { II } \\
\text { II } \\
\text { II } \\
\text { IV } \\
\text { V }\end{array}$ \\
\hline $\begin{array}{l}\text { Pallas/Matorova, } \\
\text { (EMEP, } \\
\text { GMOS/GOS4M) }\end{array}$ & $\begin{array}{l}\text { Sub-arctic } \\
\text { background } \\
\text { (boreal forest) }\end{array}$ & $\begin{array}{l}\text { PM } \\
\text { Deposition }\end{array}$ & $\begin{array}{l}1996-2018 \\
1998-2007\end{array}$ & $\begin{array}{l}\text { III } \\
\text { IV }\end{array}$ \\
\hline Virolahti (EMEP) & $\begin{array}{l}\text { Rural } \\
\text { background }\end{array}$ & $\begin{array}{l}\text { PM } \\
\text { Deposition }\end{array}$ & $\begin{array}{l}2007-2018 \\
1998-2007\end{array}$ & $\begin{array}{l}\text { III } \\
\text { IV }\end{array}$ \\
\hline $\begin{array}{l}\text { Hyytiälä (SMEAR, } \\
\text { EMEP) }\end{array}$ & $\begin{array}{l}\text { Rural } \\
\text { background } \\
\text { (boreal forest) }\end{array}$ & PM & 2017-2018 & III \\
\hline Ähtäri (EMEP) & $\begin{array}{l}\text { Rural } \\
\text { background }\end{array}$ & PM & 2007-2016 & III \\
\hline $\begin{array}{l}\text { Hailuoto } \\
\text { (HELCOM) }\end{array}$ & $\begin{array}{l}\text { Marine } \\
\text { background }\end{array}$ & Deposition & 1998-2007 & IV \\
\hline Hietajärvi (ICP IM) & $\begin{array}{l}\text { Rural } \\
\text { background } \\
\text { (boreal forest) }\end{array}$ & Deposition & 1998-2007 & IV \\
\hline Utö (HELCOM) & $\begin{array}{l}\text { Marine } \\
\text { background }\end{array}$ & Deposition & 1998-2003 & IV \\
\hline Oulanka (EMEP) & $\begin{array}{l}\text { Rural } \\
\text { background } \\
\text { (boreal forest) }\end{array}$ & Deposition & 1998-2007 & IV \\
\hline Kevo & $\begin{array}{l}\text { Sub-arctic } \\
\text { background }\end{array}$ & Deposition & 1998-2007 & IV \\
\hline
\end{tabular}

* Mobile study: measurements performed in a moving car in all major cities and a large number of industrial sites, traffic environments and rural areas in Finland. 
data collected as part of these international programs (Papers III-V) and short campaign studies dedicated to this thesis only (Papers I and II).

The measurements in Helsinki were conducted in Isosaari, a small island about $8 \mathrm{~km}$ southeast from the shore of Helsinki city centre (Paper I). Currently (as of January, 2020) the island is open for public but during the campaign, it was governed by Finnish Defence Forces and the military recruits were maintaining a weather station for FMI. The weather station was utilised for the mercury study.

In the nationwide survey, the measurements were performed in a moving car driving $10-120 \mathrm{~km}$ $\mathrm{h}-1$ depending on the area. In areas where higher than background concentrations were expected or detected, we drove very slowly around to observe the concentration variations within the area. However, with this technique it is not possible to comment about the typical concentration level in the studied area, instead, it gives valuable information about possible source areas, and indication of the $\mathrm{Hg}$ pollution level in various parts of the country in a reasonably short time.

All the other sites used in the thesis are fixed long-term measurement stations representing different rural background areas far away from anthropogenic sources.

\subsection{Sampling techniques}

The sample types include atmospheric particles (Paper III) and gases (Papers I, II, III), deposition (Papers II, IV, V), and flux between soil/wetland and air (Paper II), thus, different sampling techniques were utilised. In this Chapter, the manual sampling techniques are described.

\subsubsection{Atmospheric sampling}

Sampling technique for the trace elements in particulate matter is often collection on filters with a defined flow rate using size-selective inlets. Online methods (e.g. XRF) are available but for many elements the detection limits are not adequate in background areas with very low ambient concentrations.

Filter material type varies but e.g. quartz fibre filters, cellulose nitrate and cellulose acetate membrane filters have been found suitable in the field validation tests conducted in the preparation of EN 14902 standard (EN 14902:2005, annex B). In Nordic areas, PTFE filters have been found ideal for collection of particulate matter mass and chemical composition (e.g. Makkonen et al., 2010; Pakkanen et al., 2001; Ruoho-Airola et al., 2015; Walden et al., 2017) as these filters are very low in contamination, easy to handle and do not break. This filter type may cause problems in hot, humid surroundings with high concentrations as PTFE filters clog easily. In the Nordic countries, this has not been found a problem as the PM concentrations are typically relatively low, high temperatures are seldomly occurring and air humidity remains mostly reasonable. Also, EMEP Manual (EMEP, 2001) recommends the use of Teflon or quartz filters for trace element PM sampling with the remark that Teflon can only be used for lowvolume samplers as was used in the Paper III (flow $1 \mathrm{~m}^{3} \mathrm{~h}^{-1}$ ). 
In earlier days, PM was collected on filters straight without size-selective inlets. This was also the case in Paper III study for the part of earlier years (1996-2006). As the awareness of the significance of the particle diameter to the health effects has risen, size-selective inlets have been commonly deployed to determine PM mass and chemical composition. In Europe, most often $\mathrm{PM}_{10}$ and $\mathrm{PM}_{2.5}$ cut-offs are utilised by monitoring networks as limit and target values exist for these particle sizes in EU Air Quality Directives 2004/107/EC, 2008/50/EC, and 2015/1480 (EU, 2004, 2008, 2015). For trace elements, $\mathrm{PM}_{10}$ is the regulated particle cut-off size in Europe. Also, collection of total suspended particles (TSP) may be used, e.g. in North America the local regulations reflect on the evidence that $\mathrm{Pb}$ particles of all sizes pose health risks (EPA, 2016).

As most commercial size-selective inlets are composed of aluminium and stainless steel, a Teflon $\mathrm{PM}_{10}$ inlet (sampler IVL PModel S10, see Fig. 5) was chosen in this thesis to avoid trace element contamination from the samplers. This inlet is constructed to have the same separation properties as the US-EPA inlet (Areskoug, 2016). The inlet was located at the roof of the measurement station at the height of $4 \mathrm{~m}$ above the ground level.

Currently (in 2020), trace elements in $\mathrm{PM}_{10}$ are sampled at three background stations in Finland (Fig. 4).

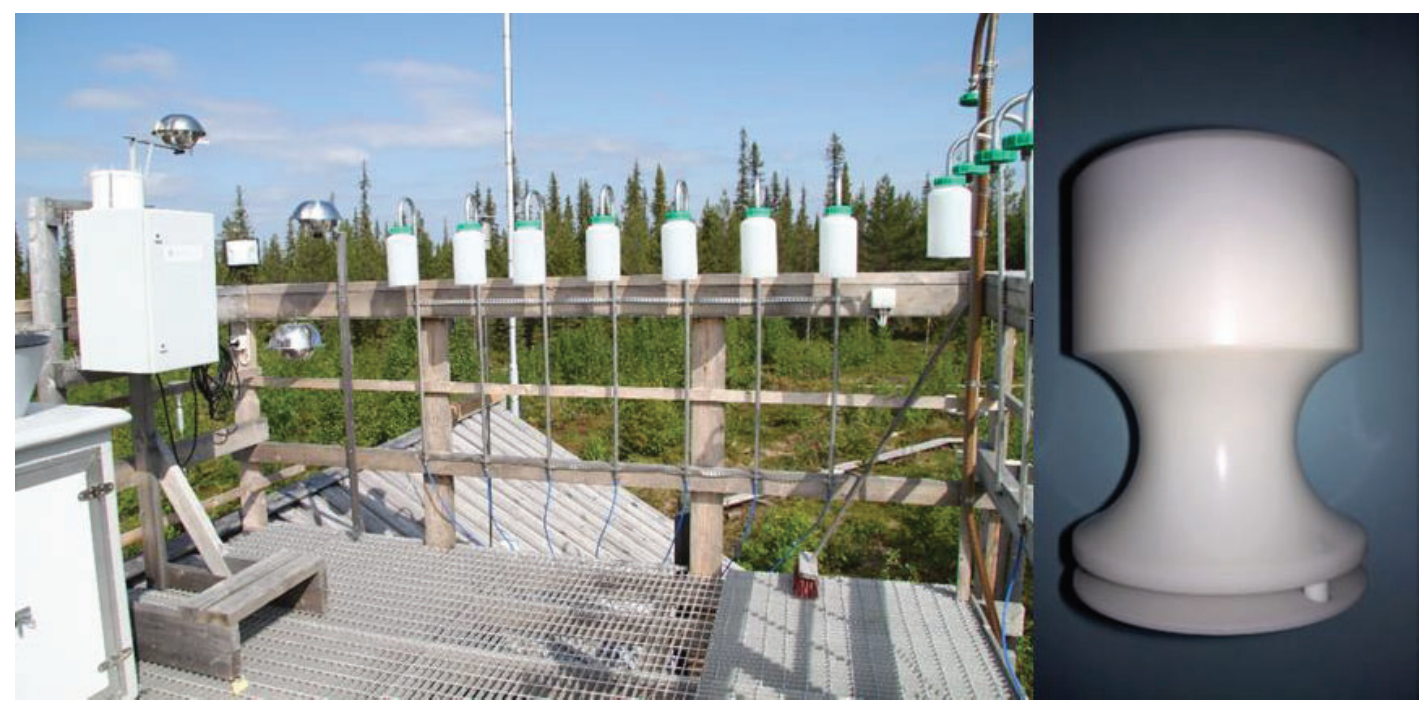

Fig. 5. On the left, sampling rooftop at the Pallas/Matorova station. Filter samplers are protected with the white rain shields. On the right, Teflon $\mathrm{PM}_{10}$ inlet used for trace element sampling.

Total gaseous mercury (TGM) can be measured with a manual gold trap method (Wängberg and Munthe, 2001). In this method, air is pulled through glass tubes containing gold, e.g. gold coated quartz glass pieces. The sampled volume is recorded with a volume meter. The tubes are later analysed in the laboratory with thermal desorption and cold vapour atomic fluorescence spectrometry (CV-AFS). Since 1990s, this technique has been often replaced with continuous online analysers (see Chapter 4.4.) although it is still used by some networks for its simplicity. At Pallas, parallel manual and online measurements have been performed since 
2008. In this thesis, only online measurements were used for TGM with the exception of Paper III where supplementary data using also manual sampling technique was utilised for source apportionment.

\subsubsection{Deposition sampling}

For deposition sampling, wet-only, bulk or dry deposition methods may be used (EN 15841: 2010; EN 15853:2010). Wet-only collectors are closed with a lid when no precipitation is occurring, and it minimises the effect of dry deposition. As wet-only samplers are not usable in the winter-time season with snow and the amount of dry deposition is relatively low in background areas, bulk collector have been chosen for routine monitoring in Finland for practical reasons.

In the thesis, the routine monitoring samples were used in Papers II, IV and V. In Paper IV, this deposition sampling technique was further validated to estimate the sampling uncertainty of the method. During the summer, the collector consists of a funnel and a bottle system while in the winter a cylinder-shaped collector is used for trace elements (Fig. 6). The collection vessel is made of high-density polyethylene (HDPE) as this material does not alter the chemical composition of the sample. The sampler parts are acid-washed in the laboratory with dilute nitric acid $\left(\mathrm{HNO}_{3}\right)$ prior to sampling. After sampling, the samples are preserved with $\mathrm{HNO}_{3}$ in the laboratory. Monthly sampling with two or three replicate collectors was used in Paper IV while one or two collectors were used in Paper V. The collectors are protected from birds with steel rings surrounding the samplers. The steel rings are coated with inert material (first plastic and later powder coating). The samplers were placed $2-4 \mathrm{~m}$ above the ground.

Currently (in 2020), deposition samples for trace elements are collected at six background stations in Finland (Fig. 4).
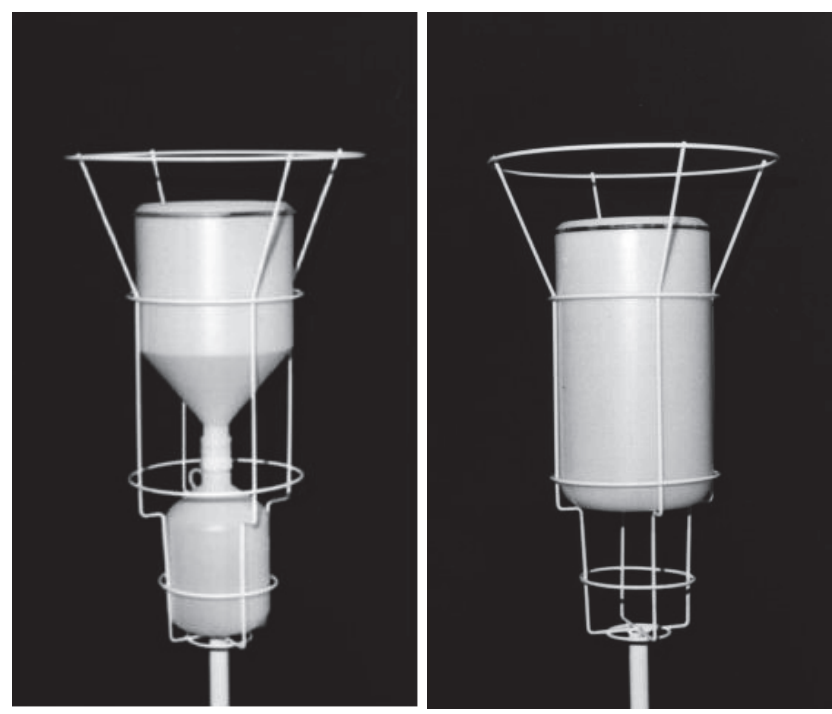

Fig. 6. Precipitation sampler for trace elements is composed of a funnel and bottle system (on the left) in the summer. During winter season, a cylinder-shaped collector is used (on the right). 
Due to the special properties of mercury, a different sampling technique was used in the thesis for this element. From May to November, this IVL type sampler was composed of a funnel (diameter $8 \mathrm{~cm}$ ) and a capillary connected to the sample bottle all made of borosilicate glass. Concentrated hydrochloric acid $(\mathrm{HCl})$ was added to the bottle before sampling to preserve the sample. During the rest of the year, the precipitation was expected to be snow, and a different setup with wide Teflon funnel $(100 \times 100 \mathrm{~cm})$ was used for sampling. For the Paper II, Finnish Environment Institute (SYKE) oversaw the sampling performed in duplicate at the ValkeaKotinen site while Swedish Environmental Research Institute (IVL) performed the analysis according to the EMEP Manual (EMEP, 2001). Since then, the samplers at Valkea-Kotinen have been replaced by a similar setup that has been modified from the IVL-type collector by the author of this thesis and her colleagues (Fig. 7). In this setup, the borosilicate glass funnel is wider (diameter $14 \mathrm{~cm}$ ) than in the IVL type collector, the $500 \mathrm{ml}$ glass sample bottle is replaced with a 1 I Teflon bottle (including $5 \mathrm{ml}$ concentrated $\mathrm{HCl}$ ) and the sampler is placed in an insulated and cooled cabin. Currently (in 2020), this $\mathrm{Hg}$ sampler is used at four background sites in Finland since 2010 (Fig. 4), nowadays only during the summer months. During the winter months, the NILU cylinder shaped collector is used since 2014 (Fig. 6). The snow sample is melted at the site and instantly preserved with $5 \mathrm{ml}$ concentrated $\mathrm{HCl}$. Prior to sampling, all the sampler parts are carefully acid washed with diluted $\mathrm{HCl}$ or $\mathrm{HNO}_{3}$ in the laboratory.
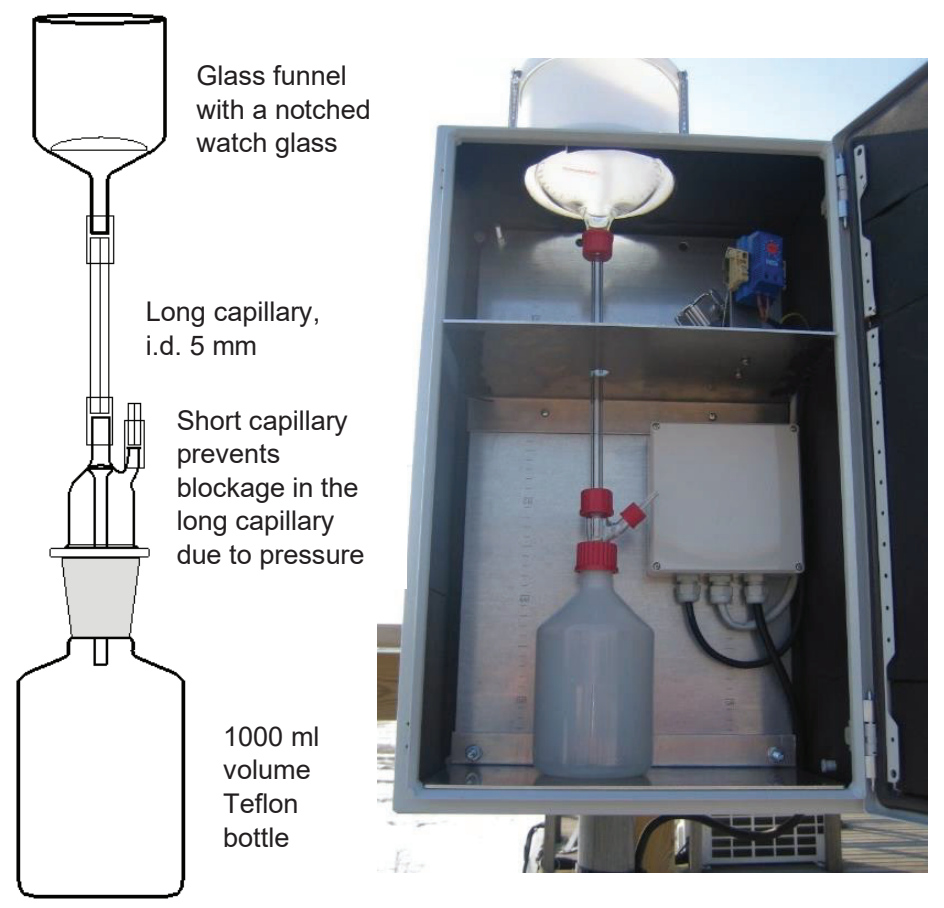

Fig. 7. A graph (modified from EN 15853:2010) and a picture of the $\mathrm{Hg}$ precipitation collector (modified from the IVL setup, photo by the author). 


\subsection{Chemical analyses}

Trace elements in PM and deposition can be analysed with e.g. atomic absorption spectrometry (AAS), inductively coupled plasma mass spectrometry (ICP-MS), inductively coupled optical emission spectrometry (ICP-OES), instrumental neutron activation analysis (INAA), proton induced X-ray emission spectrometry (PIXE) or X-ray fluorescence (XRF) techniques (e.g. Papers III-V; Aas and Bohlin-Nizzetto, 2019; Timonen et al., 2018; Virkkula et al., 1999; Visser et al., 2015). ICP-MS analysis is often the preferred method for it's extremely low limits of detection, wide linear measurement ranges, concurrent determination of the elements, rapidness and need for low amount of sample. It is also the reference method in EU legislation along with AAS (EU, 2004). The benefits of the INAA and XRF methods rely on the fact that they are non-destructive analytical techniques, however, with INAA the sample becomes radioactive waste. Before the ICP-MS analysis, the filter samples need to be digested with appropriate digestion methods to gain a liquid sample. For deposition samples, the sample needs only to be preserved with a suitable acid. For $\mathrm{Hg}$ analysis, cold vapor atomic fluorescence spectrometry (CV-AFS) and cold vapor atomic absorption spectrometry (CV-AAS) are suitable (e.g. Papers I-III; Aas and Bohlin-Nizzetto, 2019; Risch et al., 2012; Wängberg and Munthe, 2001). For deposition samples, also ICP-MS may be used for $\mathrm{Hg}$ analysis (Aas and Bohlin-Nizzetto, 2019; Harris et al., 2007).

\subsubsection{Digestion methods}

To analyse trace elements from a PM sample, the filter needs to be digested with suitable acids. Typically, concentrated $\mathrm{HNO}_{3}, \mathrm{HCl}$, hydrogen peroxide $\left(\mathrm{H}_{2} \mathrm{O}_{2}\right)$ or hydrofluoric acid $(\mathrm{HF})$, or a combination of some of these, is used. For full digestion, the procedure should be enhanced with a heating in microwave oven, an ultrasound treatment or other accelerating technique.

In paper III, two digestion methods were used. First, a digestion with mixture of concentrated $\mathrm{HNO}_{3}$ and $\mathrm{HF}(2.25 \mathrm{ml}$ and $0.75 \mathrm{ml}$, respectively) in an ultrasound bath (15 min) was performed, followed with a repeated ultrasound treatment after addition of $12 \mathrm{ml}$ of Milli-Q water (Jalkanen and Häsänen, 1996). This method was used for the samples collected in 1996-2009. After a change of the analysis laboratory to a subcontracted one, EN 14902:2005 method was chosen for digestion. This technique involves concentrated $\mathrm{HNO}_{3}$ and $\mathrm{H}_{2} \mathrm{O}_{2}(3 \mathrm{ml}$ and $0.75 \mathrm{ml}$, respectively) digestion in a microwave oven followed with dilution to $30 \mathrm{ml}$ with Milli-Q water. As a microwave oven, CEM Mars Xpress at $200^{\circ} \mathrm{C}$ and Milestone Ultrawave at $240^{\circ} \mathrm{C}$ were used.

\subsubsection{ICP-MS analysis}

Over the years, different ICP-MS instruments were used including PerkinElmer Elan 5000, PerkinElmer Elan 6000, PerkinEImer DRCII, and Thermo iCAP Q (Papers III-V). Quality control (QC) procedures included daily calibration, internal standardization $\left({ }^{45} \mathrm{Sc},{ }^{71} \mathrm{Ga},{ }^{73} \mathrm{Ge},{ }^{103} \mathrm{Rh}\right.$,

${ }^{193} \mathrm{Ir}$ ), blanks, control samples independent of calibration solutions, replicate samples and use of certified reference materials (CRMs) during the years. The CRM matrices have been coal fly ash (NIST SRM 1633b), urban particulate matter (NIST SRMs 1648 and 1648a), vehicle exhaust particulates (NIES No. 8 certified by National Institute for Environmental Studies, 
Onogawa Japan), and simulated rainwater (TMRAIN-95 certified by the National Water Research Institute, Canada). Also, external QC was accomplished with annual EMEP intercomparisons for metals in synthetic precipitation, and participation in the Intercomparison exercise for heavy metals in $\mathrm{PM}_{10}$ by EC-JRC-IES in 2007, and in the Development of particulate matter certified reference materials $\left(\mathrm{PM}_{10} \mathrm{CRMs}\right)$ by EC-JRC-IRMM (PAH's and trace elements) in 2007.

\subsubsection{CV-AFS analysis}

For $\mathrm{Hg}$ in deposition, CV-AFS was used in Papers II and V. This analysis was performed by IVL using the US-EPA method 1631 (accredited) until 2009 when the analysis was transported to the FMI laboratory (method validated by the author of this thesis). In the method, the preserved sample is treated with bromine monochloride to oxidise all the mercury in the sample before analysis. Just before the analysis, the sample is treated with a prereductant to remove excess bromine. In the analysis, tin(II)chloride is added in the sample to reduce the mercury in the sample to $\mathrm{Hg}^{0}$, which is purged with argon for detection. Since then, CEN reference method has been published (EN 15853:2010).

\subsection{Online measurements}

\subsubsection{CV-AFS for TGM analysis}

The online method for TGM analysis is similar to the one described in Section 4.3.3. As the mercury in the sample is already gaseous, the use of reagents is not needed, and the sample can be detected straight or preconcentrated first with gold amalgamation. In Papers I-III, Tekran 2537 (A, B and X models) analyser was used. In this continuous technique, the sample stream is first directed through a Teflon filter (diameter $47 \mathrm{~mm}$, pore size $0.2 \mu \mathrm{m}$ ) to remove the particulates from the sample, and then preconcentrated using two gold cartridges in turn. While one cartridge is being sampled for $5 \mathrm{~min}$, the other is being desorbed and the mercury in the sample analysed with AFS in a cycle less than $5 \mathrm{~min}$. The sample flow rate was $1.0-1.5 \mathrm{I} \mathrm{min}{ }^{-1}$, and argon 5.0 or 6.0 was used as a carrier gas (purity 99.999-99.9999\%). With these parameters, a detection limit of $0.1 \mathrm{ng} \mathrm{m}^{-3}$, repeatability of $2 \%$ and measurement uncertainty of $10 \%$ was calculated. In Paper I, the analyser was calibrated every $25 \mathrm{~h}$ while in Paper III it was performed first every $25 \mathrm{~h}$ and later every $71 \mathrm{~h}$ with its internal permeation source. In Paper III, the international permeation source was verified with manual calibrations approximately every 6 months.

\subsubsection{Mobile measurement setup}

In Paper I, the Tekran analyser described in Section 4.4.1 was placed in a car, and the electrical power for the equipment was obtained from the car battery with a 12VDC/230VAC inverter (Fig. 8). Sampling line (Teflon) was routed out of the car and the inlet placed above the car roof ahead of the car's exhaust pipe, thus, the effect of exhaust fumes was prevented when the car was moving. The analyser was calibrated with the internal permeation source at the start 
of the measurement day and repeated later when necessary. The calibrations were stable with a relative standard deviation (RSD) of $5 \%$. Two out of 15 calibrations were omitted from the dataset but later in the same day successfully repeated.
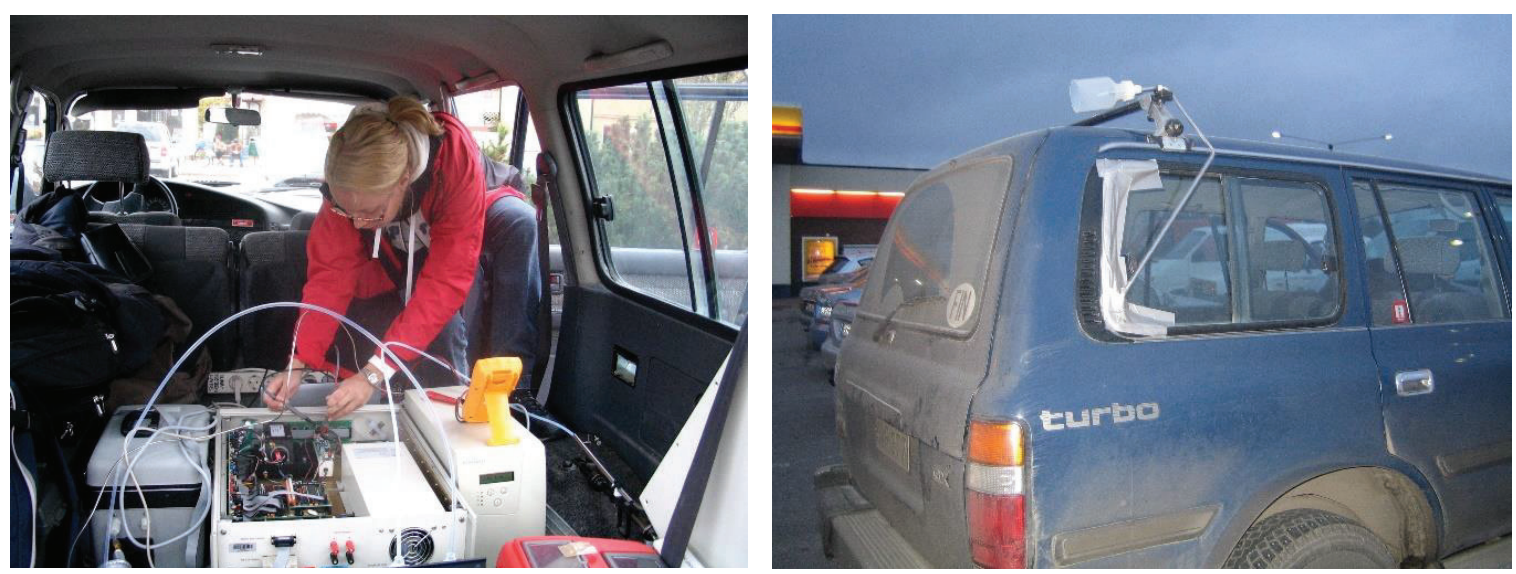

Fig. 8. During the mobile measurement campaign, the Tekran 2537A analyser was placed in a car (left, photo by Mika Vestenius) with the sample inlet routed outside (right, photo by the author).

\subsection{Flux measurements for studying air-terrestrial surface exchange}

For studying flux between ambient air and a substrate, e.g. soil, wetland, or water, different methods are available. These include micrometeorological methods and chamber techniques (e.g. Carpi et al., 2007; Eckley et al., 2010; Fritsche et al., 2008; Gustin, 2012; Osterwalder et al., 2017).

Micrometeorological (MM) methods include gradient methods, the modified Bowen ratio method (MBR) and relaxed eddy accumulation (REA). The measurement result reflects the flux associated with both the vegetation and soil/litter surfaces, in some cases even water (Gustin, 2012). These methods need data on certain environmental conditions (i.e. wind velocity, turbulence conditions) and stable power supply. Typically, the footprint area on MM methods is $\geq 50 \mathrm{~m}^{2}$ and time resolution $\geq 1 \mathrm{~h}$. The gradient and MBR method require measurement of air concentration at two or more heights often done sequentially while REA method measures $\mathrm{Hg}$ concentration in air during upward and downward moving eddies.

The advantages of the flux chamber methods include portability of the system and simplicity of deployment (Gustin, 2012). Also, they are not subject to strict meteorological and site requirements of micrometeorological methods. However, the chambers cover only a small area and the representativeness of the results for the ecosystem can raise concern. Furthermore, the deployment creates a microclimate where light, temperature and relative humidity may deviate from the natural setting. The choice of the chamber material may affect the flux results. Teflon has been found most suitable in many studies as it has better blanks and less carry over between samples than polycarbonate, and it has transparency to a wide range of radiation wavelengths compared to other materials (Carpi et al., 2007; Eckley et al., 2010). Until now, no 
standardised technique is available despite the several studies reporting differences in results due to different setup methods. However, they are often the choice of method for practical reasons.

In Paper II, flux measurements were performed with a chamber method. There were three different sites used in the study, two boreal forest plots and one wetland site (Fig. 9). The chamber was made of a $0.05 \mathrm{~mm}$ thick fluorinated ethylene propylene film supported with an external aluminium frame. The dimensions of the chamber were $60 \times 60 \times 25 \mathrm{~cm}(I \times w \times h)$. At two of the sites, the chamber was seated on a stainless-steel collar mounted in the ground four months before the first measurements started. The collars remained undisturbed during the study. A water bath of ultrapure Milli-Q water between the collar and the chamber sealed the setup. At the wetland plot, no collar was needed as the chamber could be easily pressed in the soft wetland surface. A similar chamber has been employed for hydrocarbon emissions (Hellén et al., 2006). The chamber was connected to Tekran 2537A analyser with a Teflon tubing. A flow of $1.5 \mathrm{I} \mathrm{min}^{-1}$ was used in the flux experiment.
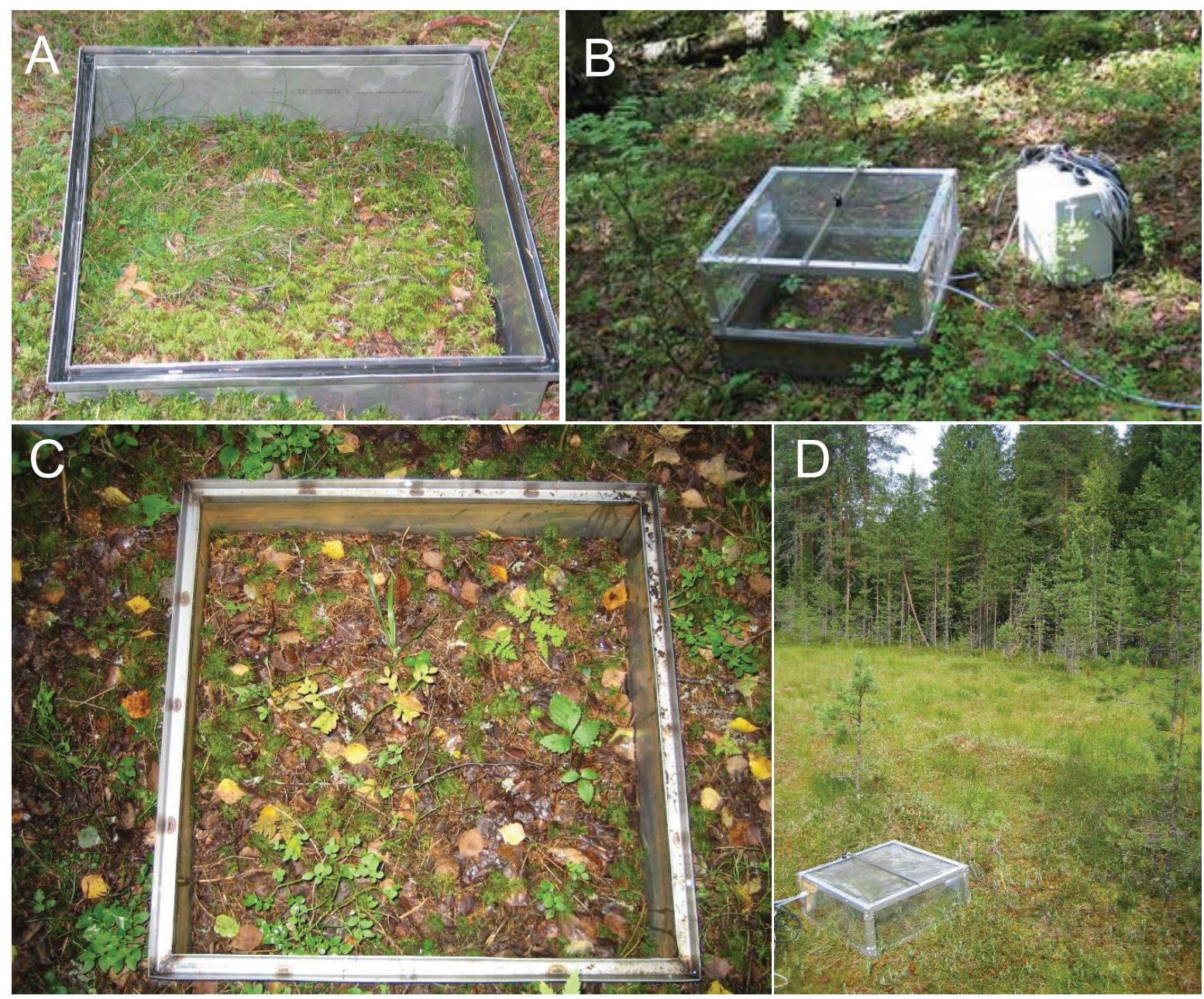

Fig. 9. The forest soil plots $L 1(A)$ and $L 2(C)$ with the sample set up connected to Tekran 2537A analyser (B), and the wetland site (D). Photos by M. Verta (A, B), and the author (C, D). 
The setup was tested prior to use for blanks and optimum experiment time. The blank tests were performed in a laboratory by placing the collar-chamber system on top of a Teflon film, and the concentration inside the chamber was compared to that in lab air (1.9 $\mathrm{ng} \mathrm{m}-3)$. As the difference was insignificant, no blank subtraction was performed. The optimum experiment time was tested in the field and found to be 20 min with this setup.

Sampling for deposition fluxes is described in Section 4.2.2.

\subsection{Data analysis methods}

In this thesis, several data analysis methods were used and those are described below.

\subsubsection{Flux calculations}

In Paper II, flux experiments were performed with the chamber method. In this method, TGM concentration grows in the chamber as it is volatilised from the surface to ambient air, or vice versa, the concentration decreases if the flux is negative, i.e. from the air to the surface. The flux $\left(F\right.$, in $\left.\mathrm{ng} \mathrm{m}^{-2} \mathrm{~h}^{-1}\right)$ is calculated according to Eq. 1:

$$
F=\frac{\frac{\Delta c}{A} V}{t}
$$

where $\Delta c$ is the concentration change in the chamber (in $\mathrm{ng} \mathrm{m}^{-3}$ ), $A$ is the plot area (in $\mathrm{m}^{2}$ ), $V$ is the volume of the chamber (in I) and $t$ is the time of the experiment.

\subsubsection{Trend calculations}

Two trend calculation methods were used in this thesis, the nonparametric Mann-Kendall test in Papers III and IV and the Generalized Least Squares (GLS) regression with autoregressive moving average (ARMA) errors in Papers III and $\mathbf{V}$.

The nonparametric Mann-Kendall test is valid for the detection of a monotonic increasing or decreasing trend of a time series with no seasonal or other periodic cycle (Gilbert, 1987; Salmi et al., 2002). In the Papers III and IV, the trend was tested at different significance levels $(P<0.1, P<0.05, P<0.01$, and $P<0.001)$ as a two-tailed test. With the additional nonparametric Sen's method, the magnitude of the trend as a slope of a linear trend was estimated, and the 95 $\%$ confidence interval for the slope estimator was calculated. Using this method, trends were calculated for annual values.

In the GLS-ARMA method, trends can be calculated for a time series with a seasonal cycle. Thus, monthly averaged values were used in Papers III and $\mathbf{V}$, however, they were deseasonalized in the analysis. In this statistical model, the autocorrelation typically present in air pollution concentration time series is accounted for by iteratively applying an ARMA-based 
correlation structure to the residuals of the fitted linear model. Details of the procedure are given in Anttila and Tuovinen (2010).

\subsubsection{Source apportionment and trajectories}

For source apportionment, the positive matrix factorisation (PMF) method was utilised in Paper III. The aim was to identify the sources of the chemical species in the weekly (or weekly averaged) samples. The model uses the time series of the species and the uncertainty matrix for each data point as defined by the user. As a result, the model produces two matrixes: the factor contribution and the factor profiles. The user choses the number of factors based on the interpretability of the results; thus, knowledge of the expected sources, their chemical composition and air chemistry is required. The PMF model is described in Paatero and Tapper (1994) and Paatero (1997). For error estimation, the bootstrap method was utilised (Paatero et al., 2014).

To trace the source regions of the PMF factors in Paper III, potential source contribution function (PSCF) was used for trajectory analysis with $120 \mathrm{~h}$ FLEXTRA air mass back trajectories (Stohl et al., 1995; Stohl and Seibert, 1998) calculated at NILU with OpenAir package in R (Carslaw and Ropkins, 2012; Carslaw, 2015).

For the interpretation of single peak values, NOAA Hybrid Single-Particle Lagrangian Integrated Trajectory model (Stein et al., 2015; Rolph et al., 2017) was utilized in Papers I and III. The trajectories were calculated for $72 \mathrm{~h}$ with the global meteorological data from the Global Data Assimilation System (GDAS) archive with a 6-h time resolution (height $500 \mathrm{~m}$ ).

\subsubsection{Enrichment factors}

The use of enrichment factors enables a simple way to characterize the source of a pollutant between natural and anthropogenic. When an element is occurring at higher concentration than expected from its natural occurrence, it is called enriched. This method can be utilized to different matrixes, e.g. aquatic and terrestrial environments (Abrahim and Parker, 2008; Barbieri, 2016; Dragovic and Mihailovic, 2009; Song and Gao, 2009), and in Paper IV, it was used for precipitation samples. The method compares the amount of an element to a reference element assumed to be totally of crustal origin, typically e.g. aluminium or iron. Enrichment factor (EF) is defined in Eq. 2 (with aluminium as a reference element):

$$
E F(\text { crust })=\frac{(X / A l) \text { precipitation }}{(X / A l) \text { crust }}
$$

where $(X / A I)$ precipitation and $(X / A l)$ crust refer to the ratio of the element $X$ to $A l$ in the precipitation and crust, respectively (Wiersma and Davidson, 1986). In Mason (1966), the average amounts of the elements in crustal rock used in the study are presented. When the EF value is close to unity, the source is expected to be mostly crustal erosion while higher numbers indicate an anthropogenic source or another natural process that enhances the amount of the element related to its crustal abundance. 


\section{RESULTS}

\subsection{Temporal and spatial trends of gaseous mercury}

Total gaseous mercury (TGM) is monitored at three background sites in Finland: Pallas, Virolahti and Hyytiälä since 2008, 2006 and 2009, respectively, with online analyzers. Typically in Finland, trace elements have a south-to-north decreasing gradient in ambient concentrations and deposition (Papers III and IV). This is not the case for TGM as the highest concentrations are measured at the northernmost station. In 2018, the annual average concentration of TGM was $1.32 \mathrm{ng} \mathrm{m}^{-3}$ at Pallas, $1.29 \mathrm{ng} \mathrm{m}^{-3}$ at Virolahti and $1.20 \mathrm{ng} \mathrm{m}^{-3}$ at Hyytiälä. Even though the differences are small, this is a systematic spatial trend that has occurred each year since the measurements started: Pallas has the highest annual concentration while Hyytiälä has the lowest (Fig. 10). There are several possible reasons for this. As stated in Section 5.4, sea is a source for TGM at Pallas, thus, the proximity of vast sea areas may enhance the TGM concentration at the site. This is supported with the fact that TGM at the Norwegian arctic and coastal sites $\mathrm{Ny}$-Ålesund and Andoya report even slightly higher annual average concentration than Pallas (Aas and Bohlin-Nizzetto, 2017; 2018; 2019). The closeness of Virolahti to some large source areas (e.g. Poland, Narva oil shale plants in Estonia) may increase the annual concentration at this site compared to the Hyytiälä site as supported with HYSPLIT backward trajectories (Fig. 11). In addition, the southern sites experience nocturnal TGM depletion events lowering the summer/autumn concentration levels.

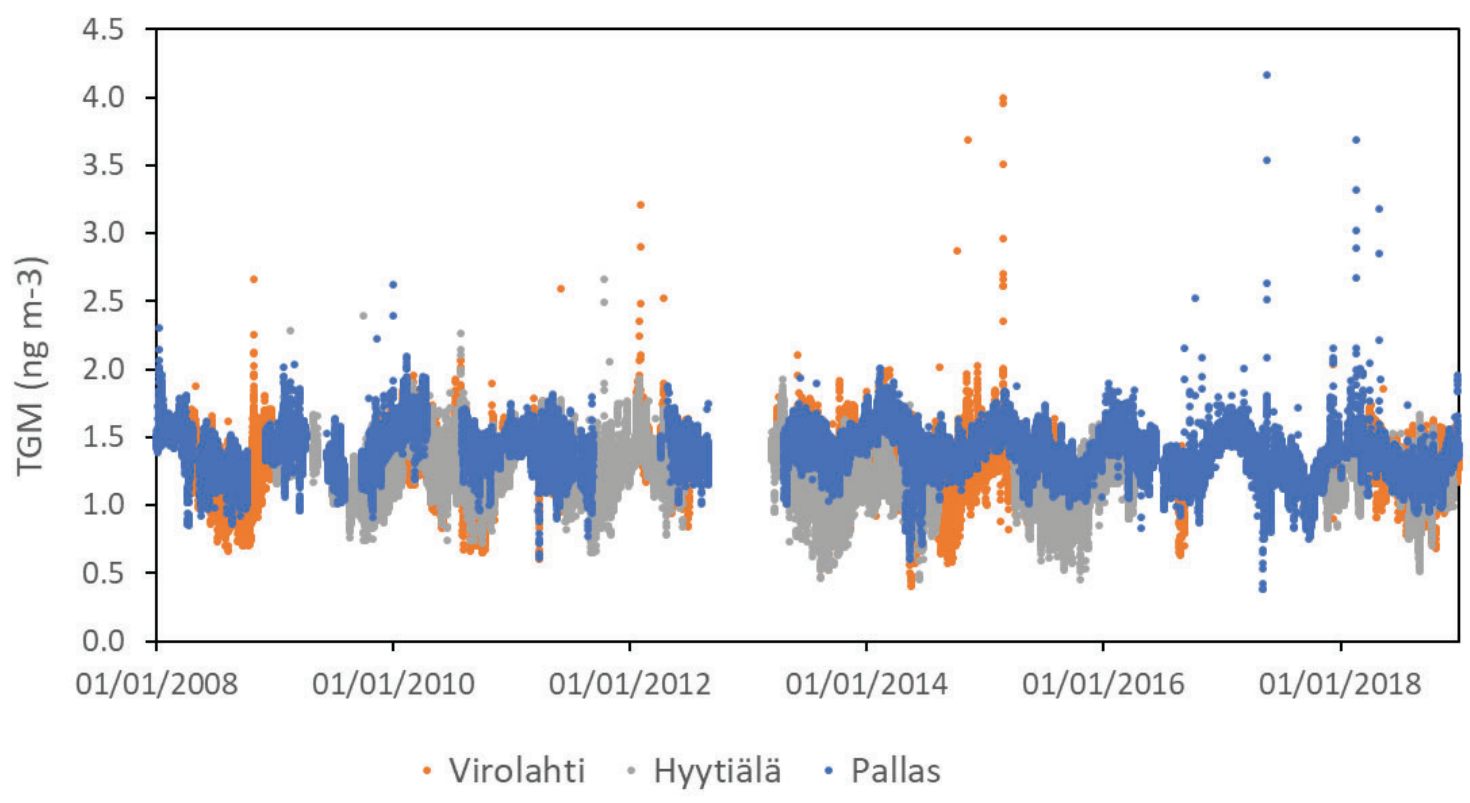

Fig. 10. The hourly TGM concentration (in $\mathrm{ng} \mathrm{m}^{-3}$ ) at the Finnish background sites during 20082018. 
NOAA HYSPLIT MODEL

Backward trajectories ending at 2100 UTC 07 Dec 17 GDAS Meteorological Data

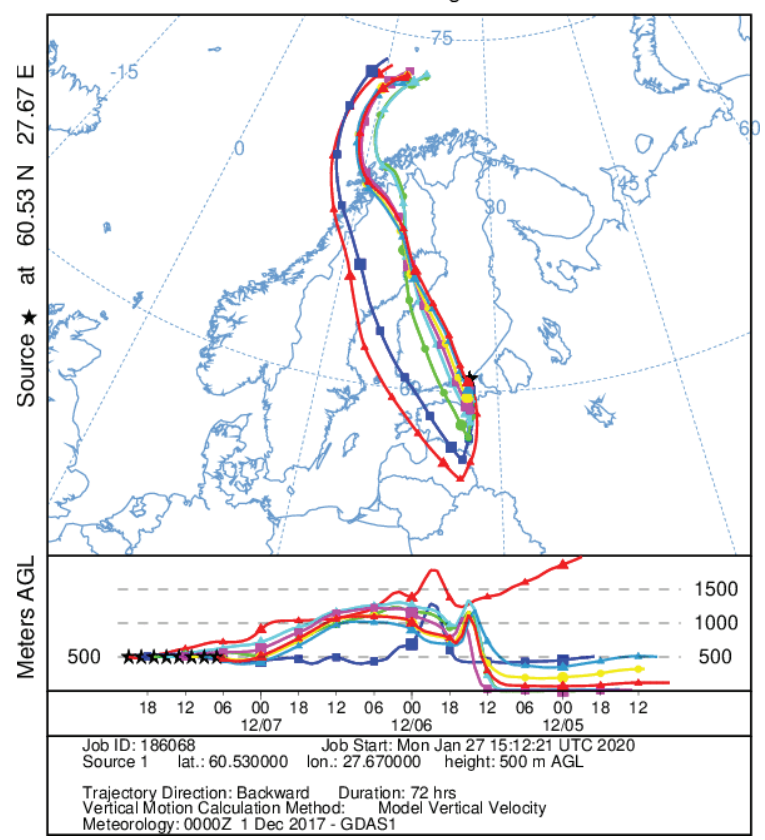

NOAA HYSPLIT MODEL

Backward trajectories ending at 1200 UTC 05 May 19 GDAS Meteorological Data

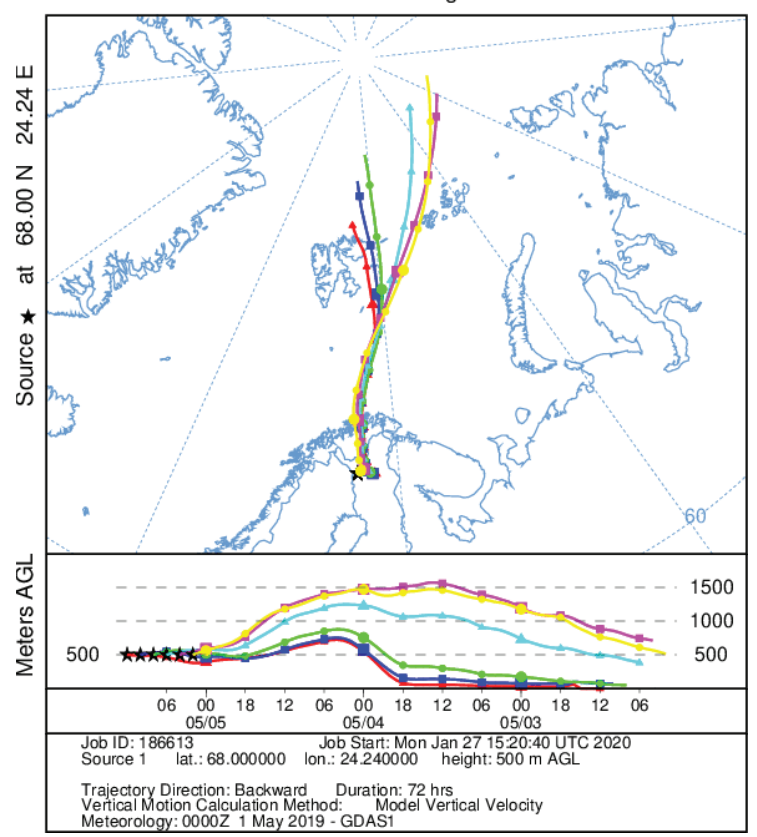

NOAA HYSPLIT MODEL

Backward trajectories ending at 2100 UTC 26 Feb 15 GDAS Meteorological Data

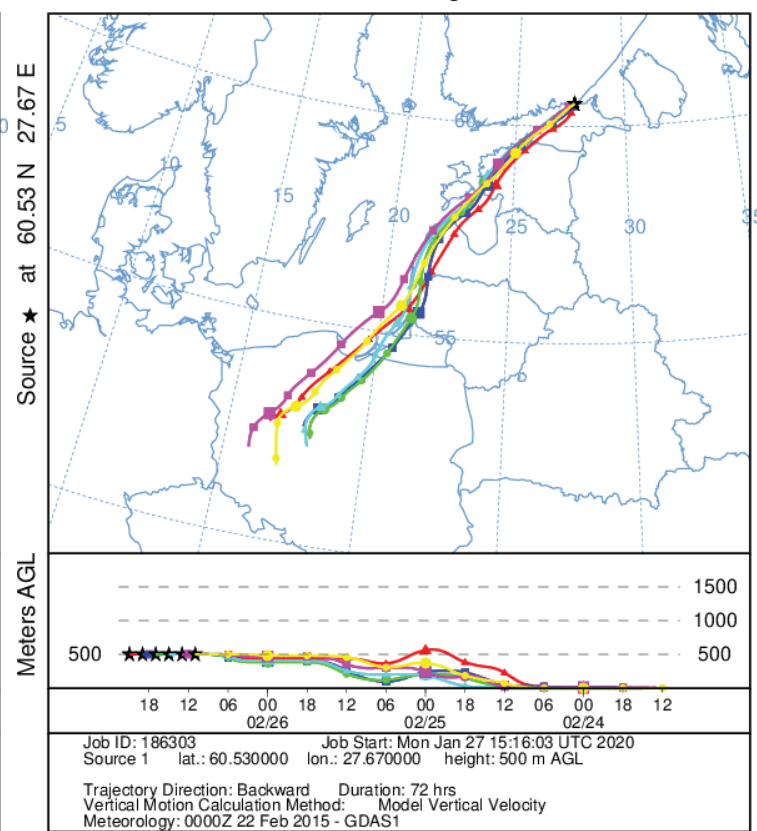

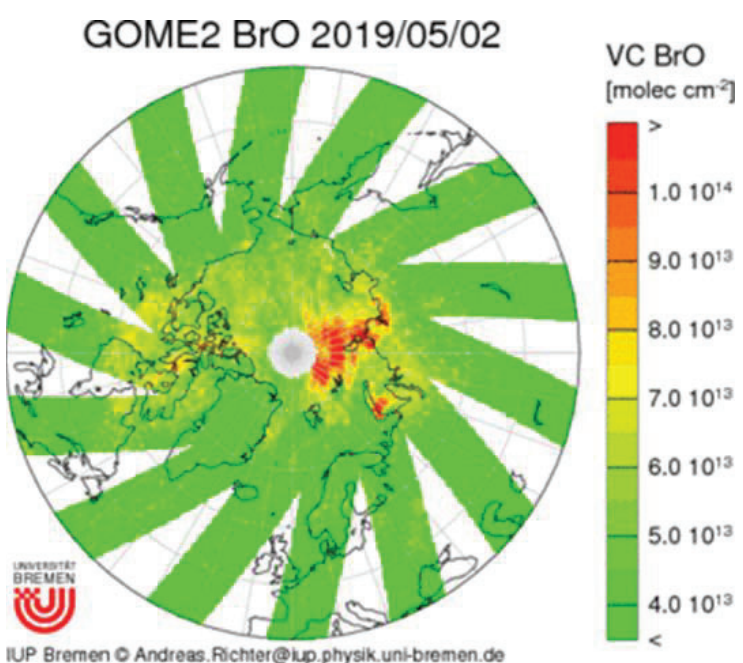

Fig. 11. Above, selected HYSPLIT backward trajectories showing the routes of the air masses carrying elevated levels of TGM to Virolahti site. Below, backward trajectories (left) and GOME2 $\mathrm{BrO}$ satellite observations (right) indicate that the low TGM concentrations measured at Pallas in $5^{\text {th }}$ of May 2019 likely originate from depleted airmasses arriving to the site from the high Arctic. 
The TGM concentrations show a seasonal cycle with higher concentration in the winter and lower in the summer/autumn. This is likely due to higher anthropogenic emissions in the cold winter months than in the warm season. Another well accepted reason is the faster oxidation rates of $\mathrm{HgO}$ in the summer (Lin et al., 2012). In a recent study by Jiskra et al. (2018), the lower TGM concentrations in the autumn at terrestrial sites is suggested to result from vegetation uptake. This study included Pallas TGM data; the other Finnish sites have a similar pattern as well.

In the arctic areas, atmospheric mercury depletion events (AMDE) are observed every spring when the TGM concentration drops close to zero after the polar sunrise (Schroeder et al., 1995; Steffen et al., 2008). Even though $\mathrm{HgO}$ has a rather long lifetime of 0.5-2 years in the atmosphere (Schroeder and Munthe, 1998; Selin, 2009), during AMDEs, the concentration drops quickly as gaseous elemental mercury (GEM) is converted to more reactive species (gaseous oxidised mercury, GOM) following a subsequent association to aerosols in the air and/or deposition to the environment (Steffen et al., 2008). This phenomenon involves a series of photochemically initiated reactions that involve halogens, e.g. bromine oxide (BrO). Thus, when the amount of $\mathrm{BrO}$ is high in the air, it favors the occurance of AMDE in the area.

At Pallas, AMDEs are not occurring at the site as it locates over $200 \mathrm{~km}$ from the sea but traces of atmospheric depletion events due to arctic winds carrying depleted air masses are observed occasionally during springtime (Fig. 10; Nerentorp et al., 2013). During these periods, the TGM concentration goes below $1 \mathrm{ng}$ m-3. In May 5 2019, hourly TGM decreased to it's recorded minimum of $0.4 \mathrm{ng} \mathrm{m}-3$. With HYSPLIT backward trajectories and GOME2 BrO satellite observations the low concentrations could be traced to polar springtime conditions favoring AMDEs (Fig. 11). Similar low concentrations may be observed at the southern sites as well.

Regarding temporal changes, no statistically significant linear trends are observed at the Finnish background sites for TGM (Fig. 12). Moreover, there has been no change in TGM concentration at Pallas since the start of the manual sampling in 1996 (Kyllönen, 2019).

In Paper I (nationwide survey), TGM concentrations below the Northern Hemisphere average of $1.7 \mathrm{ng} \mathrm{m}^{-3}$ (as reported in 2003 by Slemr et al.) were observed in most areas in Finland (Fig. 13). During the study, $89 \%$ of data remained under this value and only $2 \%$ of the data exceeded $3 \mathrm{ng} \mathrm{m}^{-3}$ while the median was $1.56 \mathrm{ng} \mathrm{m}^{-3}$ in the nationwide survey. Significantly elevated concentrations were observed at locations close to former chlor-alkali plants currently used for chemical industry and at the vicinity of a waste disposal plant. It remained unsolved if the elevated concentrations (up to $14 \mathrm{ng} \mathrm{m}^{-3}$ ) were due to current activities of the plants or a result of past activities at the site e.g. re-emission of TGM from polluted ground. At the time, there was still one active chlor-alkali plant in action in Finland utilising mercury in the process, however, it has ceased the use of $\mathrm{Hg}$ since. During the study, the surroundings of this plant were surveyd and TGM concentrations up to $4.6 \mathrm{ng} \mathrm{m}^{-3}$ were measured next to the industrial area where the plant located. However, it cannot be confirmed if the elevated concentrations were due to the plant activities or other processes in the area. Slightly elevated concentrations up to $2.8 \mathrm{ng} \mathrm{m}^{-3}$ were observed at five other industrial sites. Near crematories, no increase in TGM concentration was detected at the time of the campaign. For the capital Helsinki, a oneyear average of $1.54 \mathrm{ng} \mathrm{m}^{-3}$ was recorded in 2006-2007. Surprisingly, extreme ambient concentrations up to $2500 \mathrm{ng} \mathrm{m}^{-3}$ were recorded during a shooting practise by the military; the $\mathrm{Hg}$ was speculated to originate from $\mathrm{Hg}$ fulminate in the rounds shot during the training. 

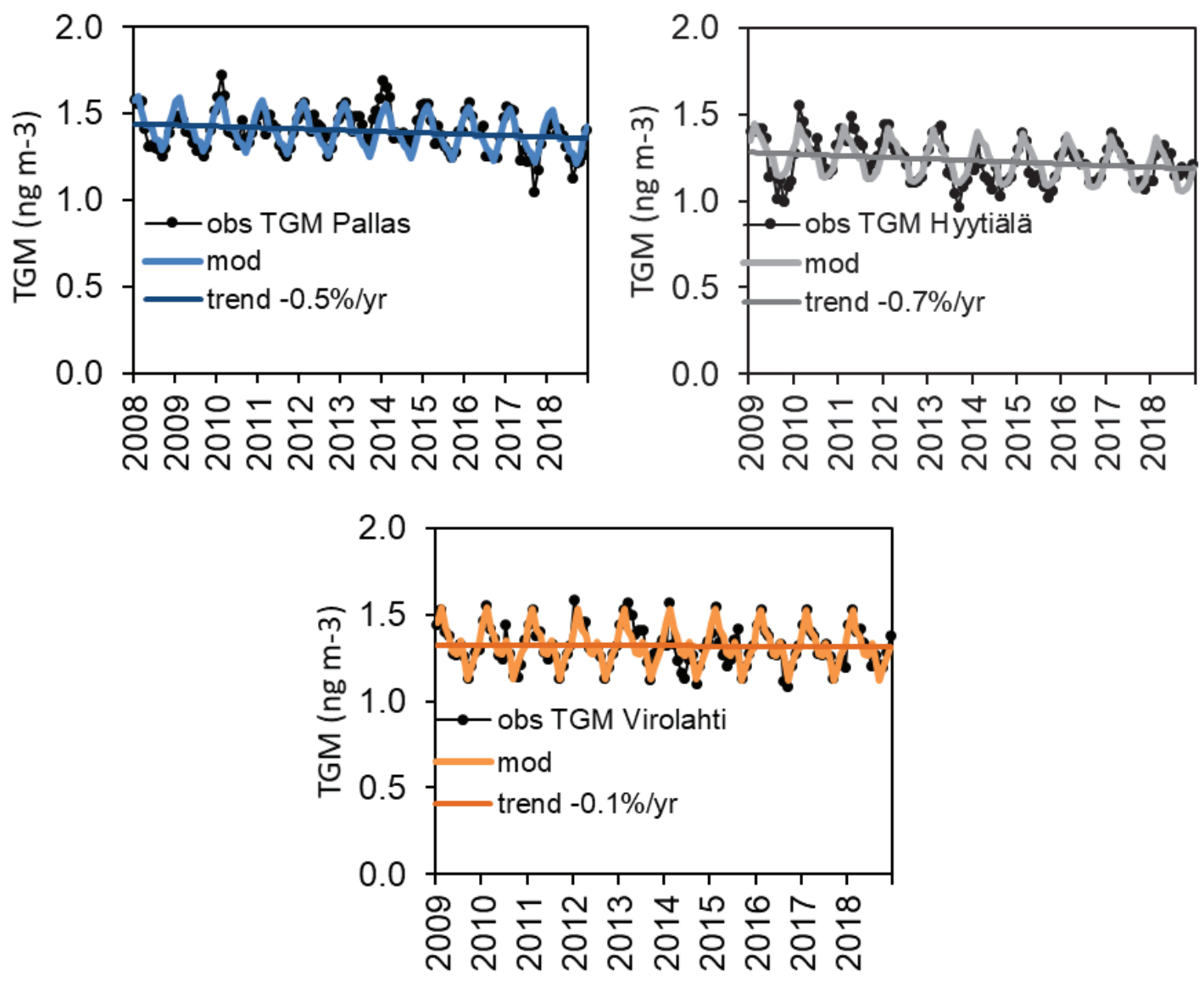

Fig. 12. The measured (obs) and modelled (mod) monthly TGM concentrations with annual trends at the Finnish background sites in 2008-2018. The trends are not significant at the $95 \%$ confidence level.

\subsection{Temporal and spatial trends of atmospheric trace elements in PM}

The annual average concentration of selected elements in PM at the Finnish background sites in 2007-2018 is shown in Fig. 14. The chosen elements are the priority pollutants of the EU air quality regulations. For trace elements in $\mathrm{PM}$, a clear south-to-north decreasing gradient was observed in Paper III. This is due to minor local sources and longer distance to the large European source areas in the north than in the south. Additionally, length of the snow-cover period has an effect on resuspension of some of the elements. However, for nickel the annual concentration at the northern Pallas station sometimes exceeds that in Ähtäri and Hyytiälä 600$700 \mathrm{~km}$ south. As stated later in Section 5.4 for Pallas, nickel in PM originates mostly from the emissions of the large Cu-Ni smelters in the Kola Peninsula resulting in occasional large Ni concentration peaks at Pallas (Paper III). 
Generally, the concentrations of trace elements in PM are among the lowest in Europe (Aas and Bohlin-Nizzetto, 2018; 2019). Comparing the 1996-2018 averages of $\mathrm{As}, \mathrm{Cd}, \mathrm{Ni}$ and $\mathrm{Pb}$ to the respective EU limit and target values, the air concentrations at the Finnish sites were only 0.2$6.8 \%$ of the legislative limits.

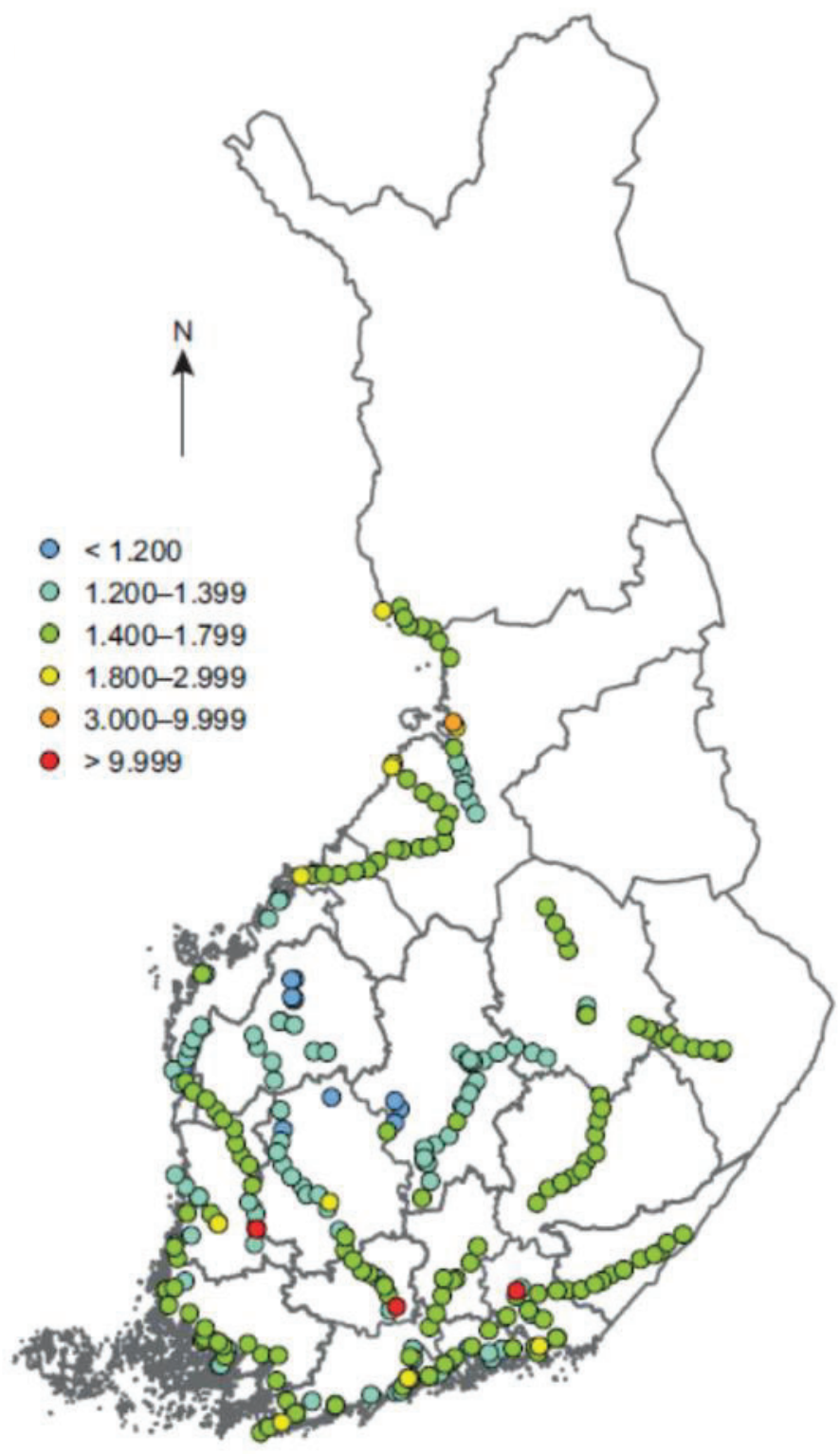

Fig. 13. TGM concentrations $\left(\mathrm{ng} \mathrm{m}^{-3}\right)$ around Finland measured during the 2007 mobile measurement campaign. Red spots present Äetsä, Riihimäki and Kuusankoski (left to right) and the orange spot is Oulu. The figure is adapted from Paper I. 

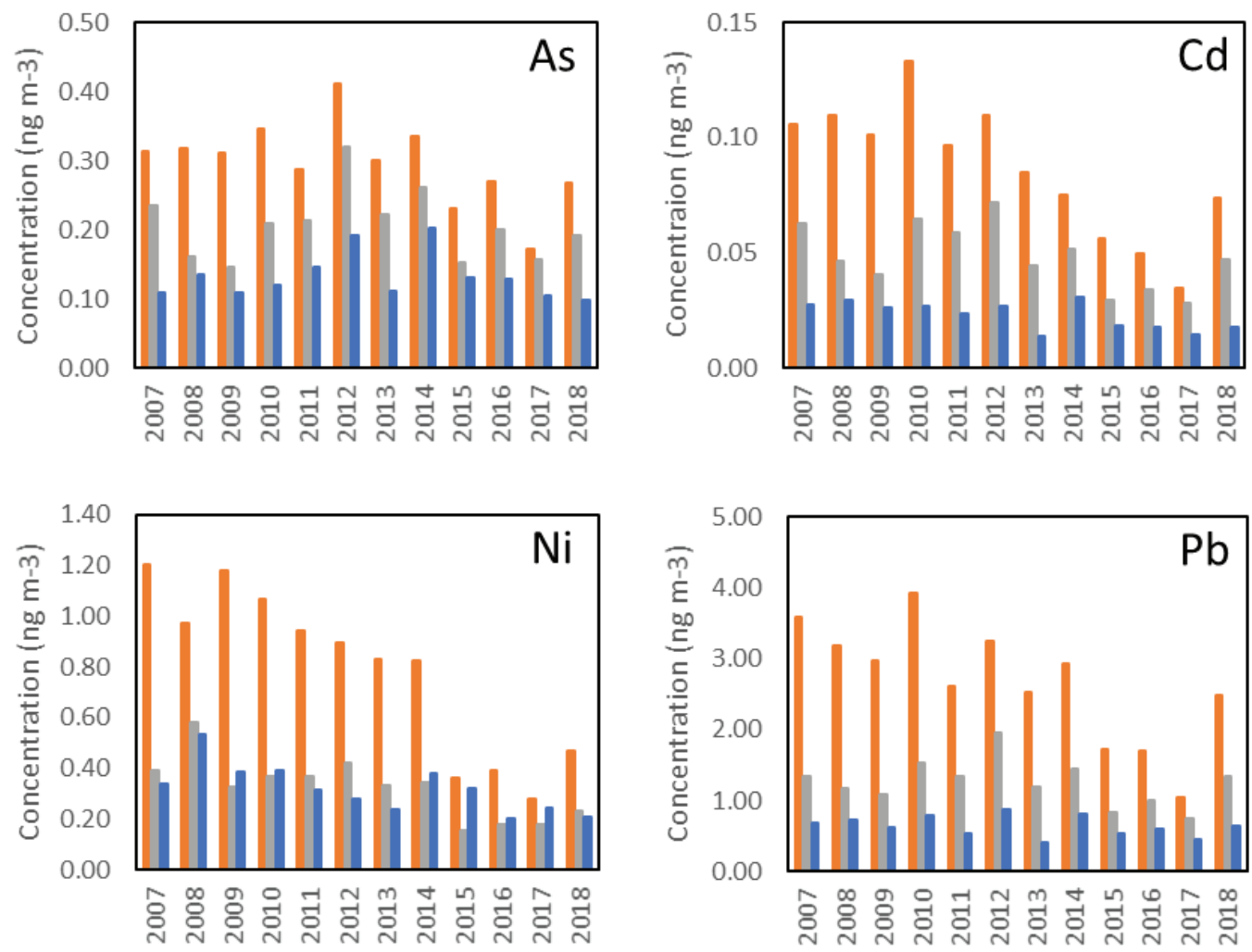

Fig. 14. The annual average concentration of priority pollutants arsenic, cadmium, nickel and lead in $\mathrm{PM}_{10}$ at the Finnish background sites in south to north order: Virolahti (orange), Ähtäri/Hyytiälä (grey) and Pallas (blue). The charts are slightly modified from Paper III.

Paper III summarizes the temporal trends of trace elements in PM at the Pallas site (Table 2). Trends were not calculated for aluminium, chromium, iron and manganese for the full data set of 23 years as the change in sampling from TSP to $\mathrm{PM}_{10}$ affected the concentration levels. In addition, for chromium the change of sample pretreatment affected the digestion yield, thus, a clear stepwise change was observed in the data. In the time series of 2010-2018, no substantial changes occurred in sampling, pretreatment and chemical analysis, thus, trends are presented for all elements for this period.

In the 1996-2018 time series, a statistically significant decreasing trend was observed for all analysed elements except zinc (Paper III). The decrease was rather steady from $51 \%$ to $64 \%$ during the 23 years measurement period. For copper, a change of $-34 \%$ was observed in 2000-2018. The decreases were attributed to changes in anthropogenic emissions. In the 2010s, cadmium, cobalt, nickel, lead, and vanadium continued to decrease with changes between 25 to $53 \%$. Now, also zinc showed a statistically significant decrease of $33 \%$. The elements mostly associated with soil origin, namely aluminium, iron and manganese, did not show statistically significant changes in the 2010-2018 data series. 
Table 2. The results of the trend analysis for monthly averaged trace element (TE) $P M_{10}$ concentrations at Pallas. Intercept and slope are presented with standard errors in parentheses. Annual changes are shown with their $\pm 95 \%$ confidence limits. Statistically significant $(P<0.05)$ trends are shown in bold text (TS, trend significance; $P<0.001,{ }^{* * *} ; \mathrm{P}<0.01,{ }^{* *} ; \mathrm{P}<0.05,{ }^{*}$ ). The table is adopted from Paper III.

\begin{tabular}{|c|c|c|c|c|c|c|c|c|}
\hline \multirow[t]{3}{*}{ TE } & \multicolumn{4}{|l|}{ 1996-2018 } & \multicolumn{4}{|l|}{ 2010-2018 } \\
\hline & Intercept & Slope & Change & TS & Intercept & Slope & Change & TS \\
\hline & $\mathrm{ng} \mathrm{m}^{-3}$ & $\mathrm{ng} \mathrm{m}^{-3}$ month $^{-1}$ & $\%$ year $^{-1}$ & & $\mathrm{ng} \mathrm{m}^{-3}$ & $\mathrm{ng} \mathrm{m}^{-3}$ month $^{-1}$ & $\%$ year $^{-1}$ & \\
\hline $\mathrm{Al}$ & - & - & - & - & $9.89(2.53)$ & $0.0295(0.0398)$ & $3.6 \pm 9.5$ & - \\
\hline As & $0.25(0.02)$ & $-0.0005(0.0001)$ & $-2.6 \pm 1.2$ & $* * *$ & $0.16(0.02)$ & $-0.0004(0.0003)$ & $-3.1 \pm 4.1$ & - \\
\hline Cd & $0.04(0.003)$ & $-0.0001(0.00002)$ & $-2.6 \pm 1.1$ & $* * *$ & $0.03(0.003)$ & $-0.0001(0.00004)$ & $-4.6 \pm 3.8$ & * \\
\hline Co & $0.03(0.002)$ & $-0.0001(0.00001)$ & $-2.2 \pm 0.7$ & $* * *$ & $0.02(0.002)$ & $-0.0001(0.00003)$ & $-4.6 \pm 3.0$ & ** \\
\hline $\mathrm{Cr}$ & - & - & - & - & $0.11(0.02)$ & $0.0007(0.0004)$ & $7.3 \pm 7.6$ & - \\
\hline $\mathrm{Cu}^{*}$ & $0.48(0.04)$ & $-0.0007(0.0003)$ & $-1.8 \pm 1.3$ & $* *$ & $0.37(0.03)$ & $-0.0002(0.0005)$ & $-0.7 \pm 3.1$ & - \\
\hline $\mathrm{Fe}$ & - & - & - & - & $15.04(1.77)$ & $-0.0260(0.0279)$ & $-2.1 \pm 4.4$ & - \\
\hline $\mathrm{Mn}$ & - & - & - & - & $0.43(0.03)$ & $-0.0009(0.0006)$ & $-2.4 \pm 3.0$ & - \\
\hline $\mathrm{Ni}$ & $0.60(0.04)$ & $-0.0014(0.0003)$ & $-2.8 \pm 1.0$ & $* * *$ & $0.37(0.04)$ & $-0.0015(0.0006)$ & $-4.9 \pm 3.7$ & * \\
\hline $\mathrm{Pb}$ & $1.13(0.09)$ & $-0.0022(0.0005)$ & $-2.3 \pm 1.1$ & $* * *$ & $0.71(0.02)$ & $-0.0016(0.0004)$ & $-2.8 \pm 1.3$ & *** \\
\hline v & $0.55(0.04)$ & $-0.0011(0.0002)$ & $-2.3 \pm 1.0$ & $* * *$ & $0.40(0.05)$ & $-0.0019(0.0007)$ & $-5.9 \pm 4.3$ & ** \\
\hline $\mathrm{Zn}$ & $2.24(0.17)$ & $-0.0019(0.0011)$ & $-1.0 \pm 1.1$ & - & $2.04(0.13)$ & $-0.0063(0.0021)$ & $-3.7 \pm 2.4$ & ** \\
\hline
\end{tabular}

*For Cu, the trend is given for 2000-2018 instead of 1996-2018.

All the studied trace elements had a seasonal cycle with some variation between elements. In addition to better illustrating the trends discussed in the previous paragraph, the Fig. 15 demonstrates the measured and modelled seasonal cycles of selected elements. For most elements, higher concentrations were observed in the wintertime when energy consumption is higher. This was especially clear for $\mathrm{Cd}, \mathrm{Pb}, \mathrm{V}$ and $\mathrm{Zn}$ (and TGM). For a group of elements (As, $\mathrm{Cu}, \mathrm{Ni}$ ), the concentrations were higher in the winter, however, the magnitude of the seasonality was smaller than the previous group indicating other sources than just energy consumption. The third group of elements ( $\mathrm{Al}, \mathrm{Fe}, \mathrm{Mn}$ ) had the highest concentrations in the spring and summer while concentrations were lowest in the early winter. The reason behind these behaviors is discussed in Section 5.4 . 

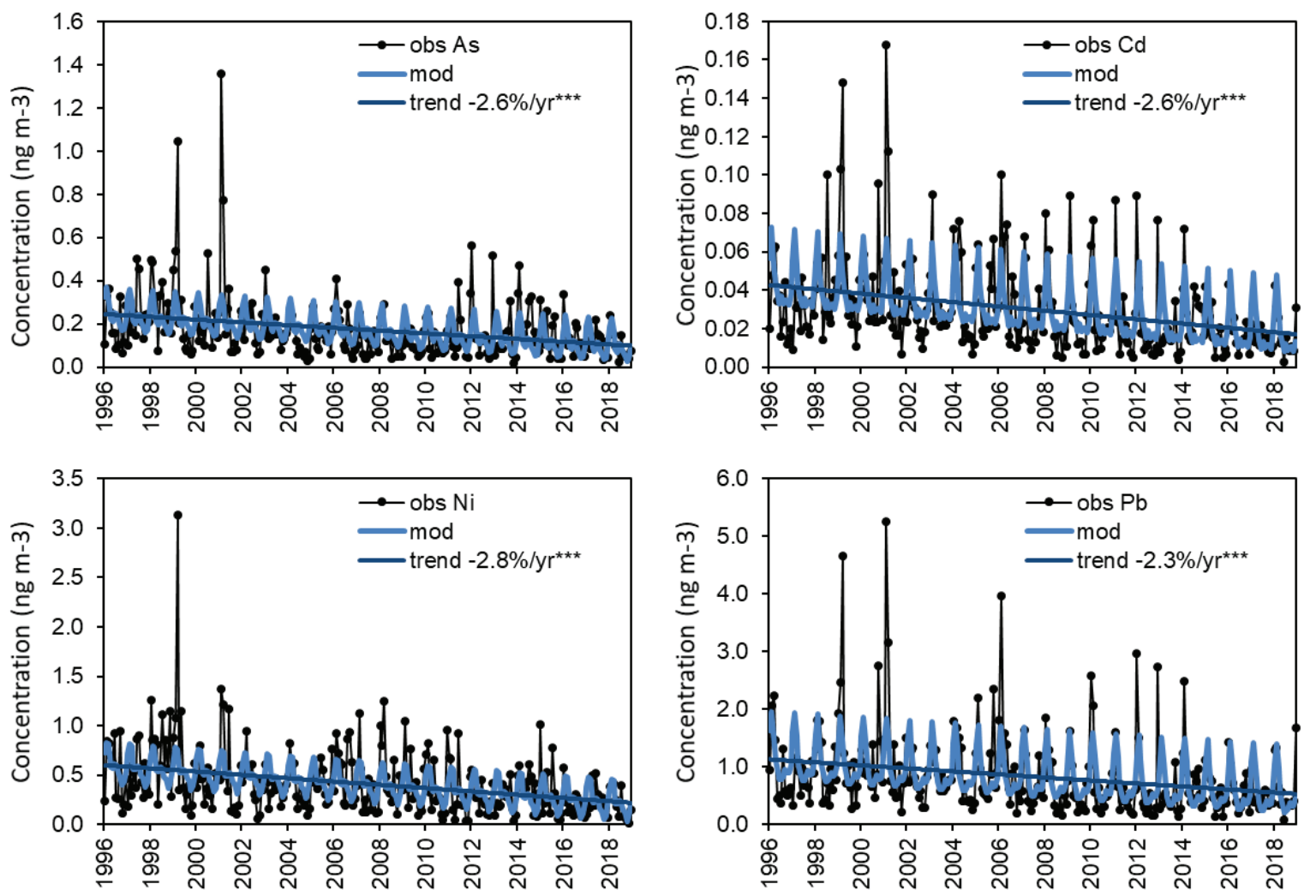

Fig. 15. The measured (obs) and modelled (mod) monthly mean concentrations of arsenic, cadmium, nickel and lead with annual trends at the sub-arctic Pallas site, Finland, in 19962018. The trends are significant at the $99.9 \%$ confidence level $\left(P<0.001,{ }^{* * *}\right)$. The charts are modified from Paper III.

\subsection{Temporal and spatial trends of trace element deposition}

The spatial trends of deposition of selected trace elements are shown in Fig. 16. In the Figure, one annual nickel value (2009) is omitted as the value of the northern-most station was three times the annual average of all stations $\left(476 \mathrm{\mu g} \mathrm{m}^{-2}\right)$, thus, raising doubt for contamination of individual sample(s) that year. However, with the available data, it is likely that the annual sum deposition was elevated that year. For cadmium, years 2010-2011 and 2015 were omitted from the figure as there were occasional contamination problems in the laboratory during that time and the source of this random contamination was identified only after rigorous investigations.

The spatial trends of trace element deposition were similar to the ones of particulate matter (Fig. 14 and 16). Again, most elements showed a clear south-to-north decreasing gradient for the same reasons as described for PM in Section 5.2. With the deposition data, the discrepant spatial trend of nickel already observed with the PM data (with elevated deposition in the northern sites) was more evident as for deposition, the number of measurement sites was 

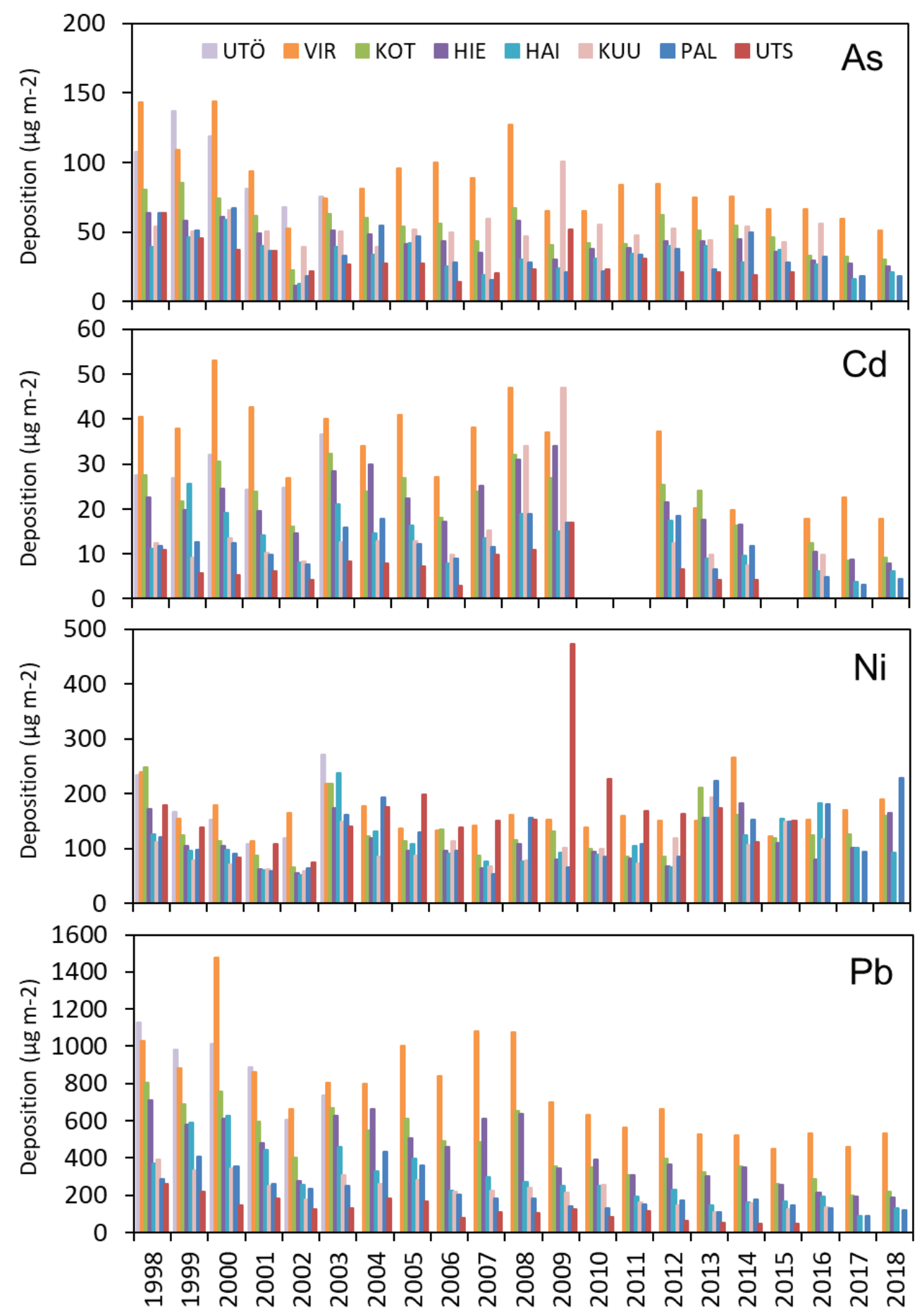

Fig. 16. The annual deposition of selected elements at the Finnish background sites in south to north order: Utö, Virolahti, Valkea-Kotinen, Hietajärvi, Hailuoto, Kuusamo Oulanka, Pallas, Utsjoki Kevo. 
higher, and the stations were more widely located around the country. Moreover, the deposition of nickel was often higher in the northern sites than in the south. Copper deposition had a rather similar pattern to nickel, however, the deposition in the northern sites was never higher than in the southern most station (Paper IV). This gives support to the conclusions on the sources of nickel in the Northern Finland pointing to the Cu-Ni industry in Kola Peninsula (Paper III; Paper IV; Paatero et al., 2008; Virkkula et al., 1999), see further analysis in Section 5.4.

There are no limit or guidance values for trace elements in deposition nor for the concentration in precipitation, however, the observed values at the Finnish sites are in the lower side among the European measurement sites (Aas and Bohlin-Nizzetto, 2018; 2019).

The trends of the annual deposition were calculated for all sites for the period of 1998-2007 in Paper IV. Additionally, trends were studied in detail for Kotinen site for the period of 1990-2011 in Paper V. Here, they are updated to cover the period of 1998-2018 for all sites (Table 3). For cadmium, the years 2010-2011 and 2015 were omitted from the analysis as described previously. For chromium, vanadium and copper, there were peculiar concentration changes in the data, thus, trends were not calculated for these elements for the 1998-2018 time series. Regarding $\mathrm{Cr}$ and $\mathrm{V}$, there was a stepwise change in the deposition level in 2010 when the analysis was transferred to a new laboratory, while for copper, there was indications of unexplained analytical problems in 2003-2009 with gradual increase in the deposition before the change of the laboratory.

Out of the elements examined for changes, all had statistically significant decreasing trends at least at one station with the exception of nickel. The rain amount, a parameter clearly affecting in the deposition, did not show any statistically significant trends. Lead was decreasing at all stations with changes between -55 and $-81 \%(P<0.001)$. Aluminium, arsenic, cadmium and zinc were also lessening at several locations with statistically significant reductions of $32-78 \%$. These decreases in deposition were attributed to changes in emissions. Furthermore, the alarming signal of increasing cadmium deposition observed until 2011 in Paper $\mathbf{V}$ has since been changed to a positive development of reducing deposition.

Manganese and iron were decreasing only at the Hietajärvi site (30 and $41 \%$, respectively, $\mathrm{P}<0.05)$ where aluminium was also decreasing by $44 \%$ indicating a common factor of changes in soil weathering at the site. On the contrary, iron was increasing by $65 \%$ at the southern-most site Virolahti $(P<0.01)$, however, this is a local phenomenon as there was no indication of increase in iron deposition at the other sites. In addition, nickel was increasing by $71 \%$ at the Kuusamo Oulanka site $(P<0.05)$ while other sites did not have statistically significant trends for nickel. In general, the only station showing a decreasing pattern of nickel (not statistically significant) was the southern Virolahti site, nevertheless, the year-to-year variation was substantial for nickel at all sites complicating the trend analysis.

Trends of mercury deposition were studied in Paper V for three time periods of 1995-2004, 2002-2011 and 2005-2011. The mean levels in the two latter periods were about $15 \%$ lower than in the first one, however, no statistically significant trends were found in the trend analysis for the three separate time series. 
Table 3. The trend significance (TS; $P<0.001,{ }^{* * *} ; P<0.01$, ${ }^{* *} ; P<0.05$, *), Sen's slope estimate (Est.) with its $95 \%$ confidence intervals (min, max), and the relative total change per period for the annual deposition of selected elements at Finnish background stations in 19982018.

\begin{tabular}{|c|c|c|c|c|c|c|c|c|c|c|c|}
\hline \multirow{2}{*}{$\begin{array}{l}\text { Site } \\
\text { code }\end{array}$} & \multirow[t]{2}{*}{ Station } & \multicolumn{3}{|c|}{ Slope $\left(\mu \mathrm{g} \mathrm{m}^{-2} \mathrm{yr}^{-1}\right)$} & \multirow{2}{*}{$\begin{array}{c}\text { Change } \\
\text { (\%) }\end{array}$} & \multirow[t]{2}{*}{ TS } & \multicolumn{3}{|c|}{ Slope $\left(\mu \mathrm{g} \mathrm{m}^{-2} \mathrm{yr}^{-1}\right)$} & \multirow{2}{*}{$\begin{array}{c}\text { Change } \\
(\%)\end{array}$} & \multirow[t]{2}{*}{ TS } \\
\hline & & Est. & Min. & Max. & & & Est. & Min. & Max. & & \\
\hline & & \multicolumn{5}{|c|}{ Aluminum } & Lead & & & & \\
\hline FI17 & VIR & & & & & & -27 & -39 & -18 & -55 & *** \\
\hline FI93 & KOT & -128 & -242 & -24 & -32 & * & -28 & -32 & -21 & -76 & *** \\
\hline FI92 & HIE & -325 & -286 & -21 & -44 & * & -24 & -30 & -17 & -72 & $* * *$ \\
\hline FI53 & $\mathrm{HAl}$ & & & & & & -19 & -25 & -12 & -81 & *** \\
\hline $\mathrm{FI} 22$ & KUU & -69 & -107 & -6 & -36 & * & -13 & -16 & -9.0 & -68 & $* * *$ \\
\hline FI36 & PAL & & & & & & -11 & -16 & -8.3 & -74 & $* * *$ \\
\hline \multirow[t]{2}{*}{ FI08 } & UTS & -42 & -83 & -9 & -37 & * & -10 & -13 & -6.7 & -81 & $* * *$ \\
\hline & & \multicolumn{5}{|c|}{ Arsenic } & Zinc & & & & \\
\hline FI17 & VIR & -2.7 & -4.4 & -1.3 & -48 & ** & & & & & \\
\hline FI93 & KOT & -2.0 & -3.0 & -1.1 & -56 & $* * *$ & -66 & -109 & -24 & -50 & ** \\
\hline FI92 & HIE & -1.5 & -2.0 & -0.7 & -51 & ** & & & & & \\
\hline FI53 & $\mathrm{HAl}$ & -0.8 & -1.5 & -0.0 & -38 & * & -44 & -73 & -12 & -47 & ** \\
\hline FI22 & KUU & & & & & & & & & & \\
\hline FI36 & PAL & -1.3 & -2.4 & -0.1 & -59 & * & -26 & -51 & -0.2 & -40 & * \\
\hline \multirow[t]{2}{*}{ FI08 } & UTS & -1.0 & -2.3 & -0.3 & -49 & ** & -20 & -37 & -5.5 & -48 & * \\
\hline & & \multicolumn{5}{|c|}{ Cadmium } & & & & & \\
\hline FI17 & VIR & -1.4 & -2.2 & -0.5 & -64 & ** & & & & & \\
\hline FI93 & KOT & -0.9 & -1.5 & 0.0 & -61 & * & & & & & \\
\hline FI92 & HIE & & & & & & & & & & \\
\hline FI53 & HAI & -0.8 & -1.2 & -0.2 & -78 & * & & & & & \\
\hline FI22 & KUU & & & & & & & & & & \\
\hline FI36 & PAL & & & & & & & & & & \\
\hline FI08 & UTS & & & & & & & & & & \\
\hline
\end{tabular}

\subsection{Sources of trace elements}

Sources of trace elements were studied with source apportionment using PMF in Paper III and enrichment factors in Paper IV. Also, the urban and industrial sources of total gaseous mercury were studied in Paper I (see Section 5.1) and natural sources and sinks of atmospheric mercury in Paper II (see Section 5.5).

In Fig. 17, the enrichment factors of the trace elements in deposition are shown (Paper IV). The values indicate the median of the years 1998-2007 separately for each station. Elements related to the crustal origin ( $\mathrm{Fe}, \mathrm{Mn}, \mathrm{Cr}$ ) showed low or slight enrichment indicating crustal weathering and wind re-suspension as important sources. Interestingly, the southern Virolahti station affected most by the long-range transport and domestic emissions due to its location had unexpectedly the lowest EF values for all elements. This suggests aluminium did not fully serve as an appropriate reference element in the analysis and the station is affected with anthropogenic aluminium sources. This was further confirmed in the monthly EF analysis (Paper IV). However, within the measured elements, no better reference element was available 
and thus, the values using aluminium are reported here. For other sites, the seasonality of the EF values proved aluminium was a suitable choice.

As expected, arsenic, cadmium, lead and zinc had EF values meaning high enrichment and implying mainly anthropogenic sources. Vanadium, nickel and copper showed intermediate enrichment while the values for nickel and copper were the highest at the northern stations further supporting the assumption of the significant arctic source of these elements from the CuNi smelters located in Kola Peninsula.

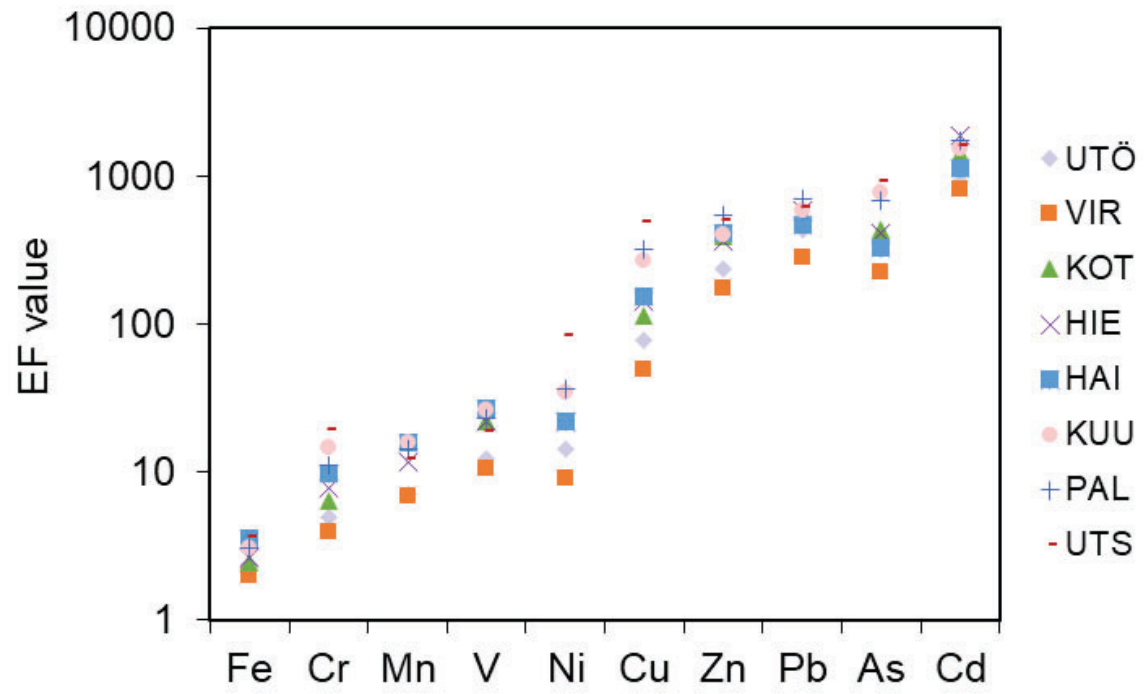

Fig. 17. The median enrichment factors of trace elements in precipitation at the Finnish background sites in 1998-2007. Abbreviations indicate the sites as follows: UTÖ=Utö, VIR=Virolahti, KOT=Valkea-Kotinen, HIE=Hietajärvi, HAI=Hailuoto, KUU=Kuusamo Oulanka, $\mathrm{PAL}=$ Pallas, and UTS=Utsjoki Kevo. The figure is modified from Paper IV.

For the Pallas PM data, source apportionment with PMF was modelled for two time series: the full dataset of 1996-2018 and the recent years of 2014-2018 (Paper III). These periods were chosen to represent the overall source categories since the beginning of the measurements and the more recent source contributions in 2010's. The PMF analysis was run with four to seven factors. The five-factor solution was adopted as it produced a good fit to the data and was reasonable to interpret. The factor contributions and factor time series are presented in Fig. 18 for the 1996-2018 data set. For the recent 5-year dataset, a similar PMF result was gained (Paper III). PMF analysis for another Finnish site Virolahti has been reported in Vestenius et al. (2011). 


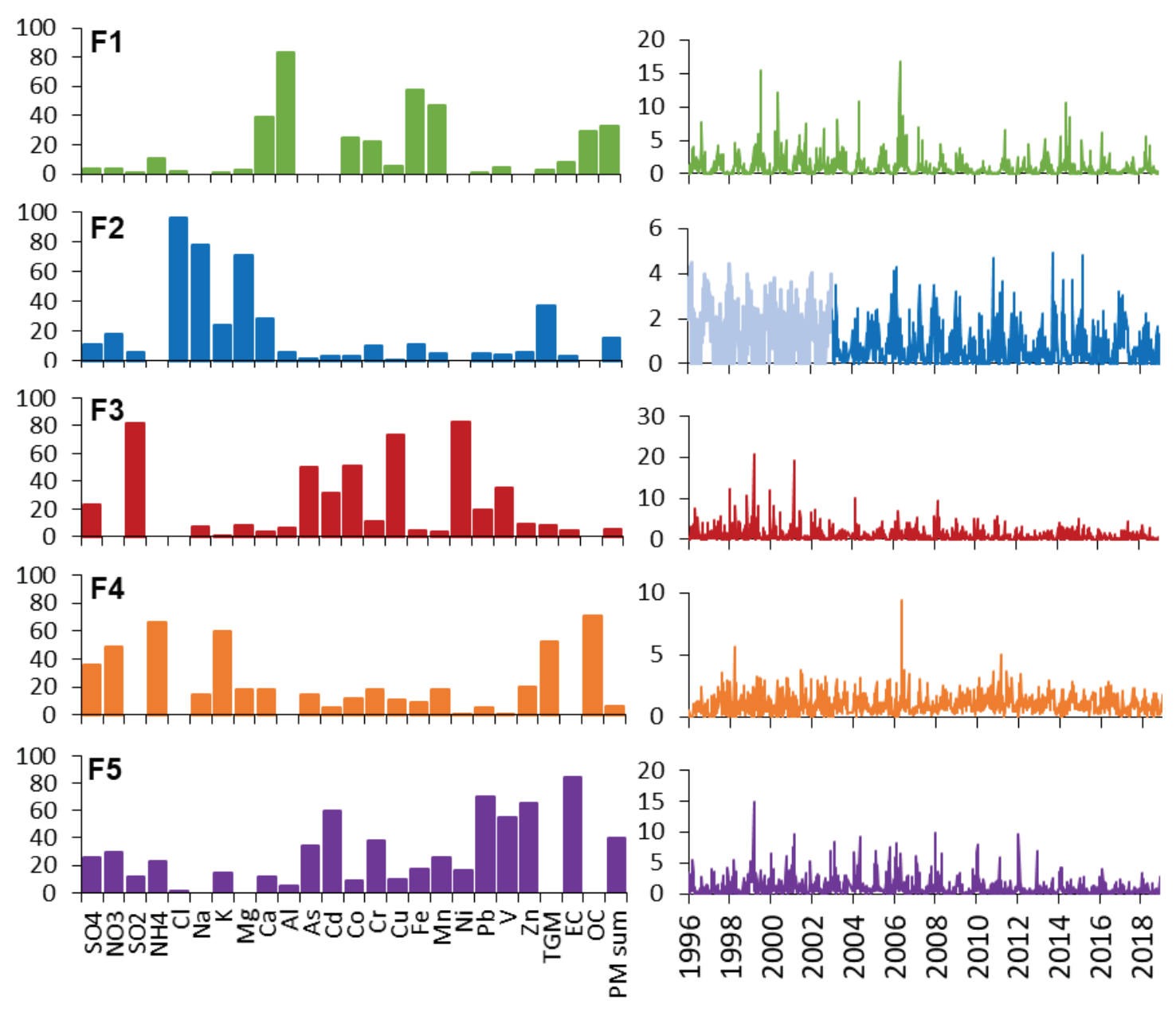

Fig. 18. The results of source apportionment for Pallas during 1996-2018. The factor compositions are presented as a percentage of each component loaded into each respective factor (left), and the relative source contribution time series (right). In the profile time series, the units are arbitrary so comparison between factors is not relevant. The figure is adopted from Paper III.

In the PMF analysis, the first factor (F1) was related to soil re-suspension as it had $83 \% \mathrm{Al}, 57$ $\% \mathrm{Fe}, 47 \% \mathrm{Mn}$ and $39 \% \mathrm{Ca}$, all typical elements for this source. Also, this factor shows strong seasonality with peaks in the summer. Interestingly, $29 \%$ of OC is seen in this factor and we hypothesize it to result from the biogenic sources. Soil is not a likely source for OC, however, another local source showing similar seasonality is the high concentrations of volatile organic compounds (VOC) originating from the vegetation in the summer (Hellén et al., 2018). VOCs react rapidly in the atmosphere and their reaction products contribute to aerosol formation and growth (Tunved et al., 2006).

The second factor (F2) had the highest loadings of $\mathrm{Na}, \mathrm{Cl}$, and $\mathrm{Mg}$; thus, it was named as the marine factor. Additionally, $37 \%$ of TGM coincided in this factor suggesting the importance of sea as a source of gaseous mercury. As supported with the PSCF analysis (Fig. 19), the factor 
represents relatively clean marine airmasses arriving from the Arctic Ocean. Similarly, a PMF study at a coastal Virolahti site reported part of TGM relating to sea salt factor (Vestenius et al., 2011).
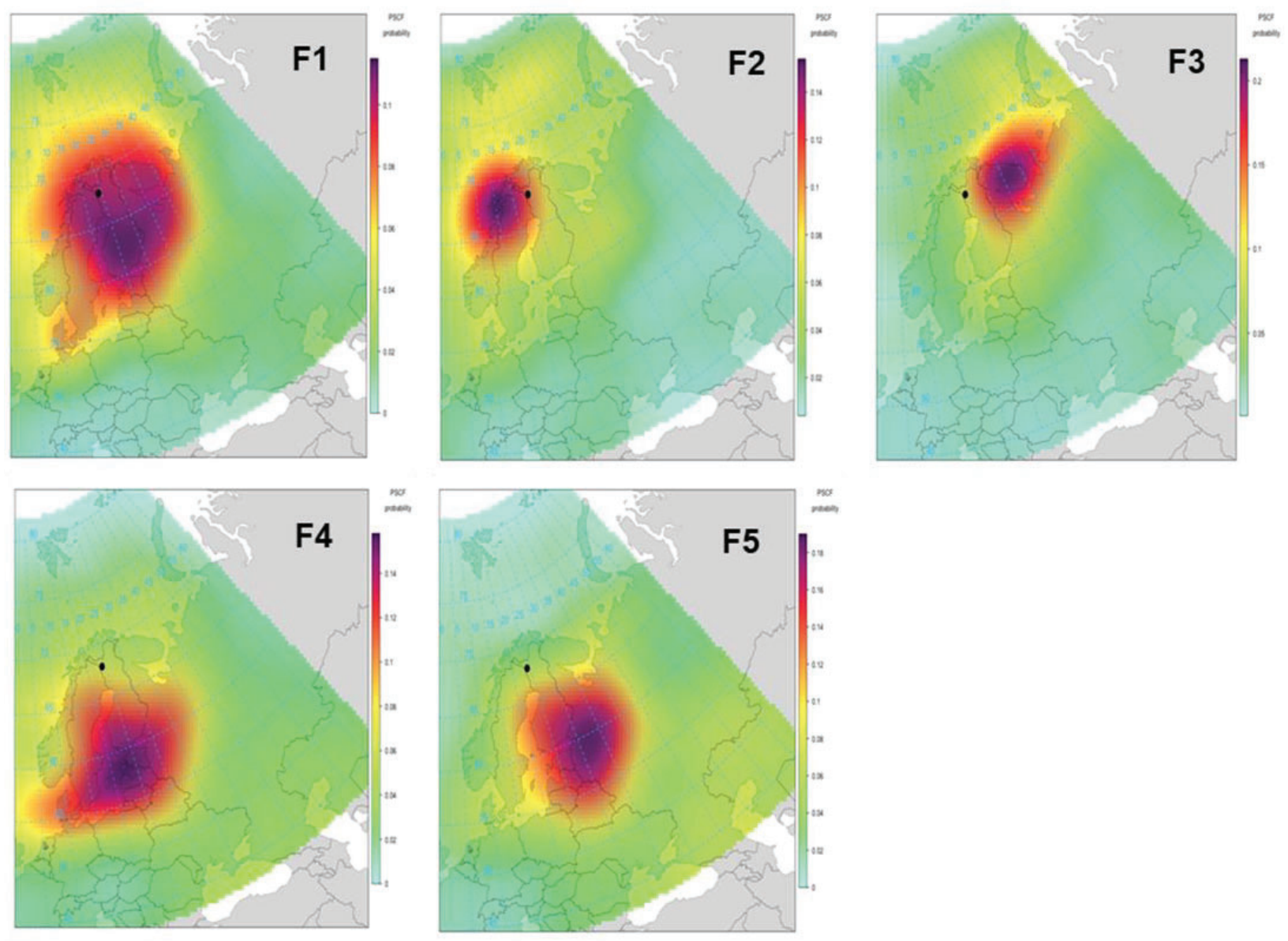

Fig. 19. Source region maps of the PMF factors F1-F5: soil, marine, non-ferrous metal smelting, secondary LRT, and combustion LRT. Pallas is denoted as a black dot. The scales of the PSCF probability differ. The figure is adopted from Paper III.

The third factor $(\mathrm{F} 3)$ accounted for $83 \% \mathrm{Ni}, 73 \% \mathrm{Cu}, 50 \%$ As and $51 \%$ Co. Also, $82 \%$ of $\mathrm{SO}_{2}$ and $23 \%$ of $\mathrm{SO}_{4}$ was seen in this factor proposing a source not too far away having most sulphur still as $\mathrm{SO}_{2}$ but enough far away that part of the $\mathrm{SO}_{2}$ had already oxidised to $\mathrm{SO}_{4}$. With the back-trajectory analysis, this source was traced to Kola Peninsula. Relying to the PSCF analysis, element composition in the factor and earlier literature (e.g. Paatero et al., 2008; Timonen et al., 2018; Virkkula et al., 1999), this factor clearly represents the effect of the emissions of the Ni-Cu smelters in Kola Peninsula to the site. Thus, it was named the nonferrous metal smelting. The decreasing time series of the factor implies that the emissions from the smelters may be lessening; this is considered a very positive signal. 
Fourth factor (F4) was identified as the secondary LRT factor. Here, high loadings of $\mathrm{NH}_{4}(66$ $\%), \mathrm{NO}_{3}(49 \%)$ and $\mathrm{SO}_{4}(36 \%)$ were recognized pointing to aged polluted air masses in which $\mathrm{SO}_{2}$ and $\mathrm{NO}_{x}\left(\mathrm{NO}-\mathrm{NO}_{2}\right)$ had been neutralized by e.g. $\mathrm{NH}_{3}$ to form $\mathrm{SO}_{4}$ and $\mathrm{NO}_{3}$. Additionally, high portions of OC $(71 \%)$, TGM (52 \%) an K (60\%) were found in this sector. Having a long lifetime, TGM is typically attributed to LRT (Durnford et al., 2010) while in the Arctic, OC can be attributed to LRT among other sources (Schneidemesser et al., 2009; Timonen et al., 2018). K is often used as a tracer for biomass burning despite having several other sources related to e.g. LRT (Pachon et al., 2013). The PSCF analysis suggests sources mostly associated with the countries south of Finland.

Fifth factor (F5) carries several trace elements that express high enrichment suggesting anthropogenic sources. These are Pb (70 \%), Zn (66 \%), Cd (60 \%), V (55 \%), Cr (38 \%) and As (34\%). Moreover, $84 \%$ of elemental carbon (EC) is found in this factor. Domestically, 70-90 $\%$ of the anthropogenic emissions of these elements is of energy production. In Europe, emissions reported for $\mathrm{As}, \mathrm{Cd}$ and $\mathrm{Pb}$ are mainly from energy production, distribution and use in industry (EEA, 2019a), while for black carbon (BC, which is closely equivalent to $E C)$, there are several reported sources including commercial, institutional and households (48\%), road transport $(28 \%)$ and energy (12\%) according to EEA (2019b). However, many studies emphasize the high portion of fossil fuel combustion and biomass burning as an EC source to the Arctic (Bond et al., 2004; Hyvärinen et al., 2011; Sharma et al., 2013; Winiger et al., 2016). Similar to our results, Nguyen et al. (2013) reported a combustion source for Greenland having high loadings of As, Pb and EC. With PSCF analysis, the source region was traced to Eastern Europe and domestic areas in the south. This is similar to Hyvärinen et al. (2011) where BC was found to mostly originate from Central and Eastern Europe while moderate source areas located in Southern Finland. For these reasons, this factor was attributed to LRT combustion sources. The factor time series showed reduction over time; this is an encouraging signal.

In the PMF analysis, the use of trace elements along with supplementary data proved to be an effective tool to separate between the sources at the site.

\subsection{Fluxes of mercury in a boreal forest and wetland}

In Paper II, air-terrestrial fluxes of TGM were studied with the flux chamber technique coupled to a mercury analyser. Most of the measurements were conducted in daytime. At the boreal forest plot L1, with moss and grass cover (see picture in Fig. 9A), the fluxes were positive, i.e. $\mathrm{Hg}$ emission occurred, during all measurement days except one (Fig. 20). Fluxes between -0.3 $-3.5 \mathrm{ng} \mathrm{m}^{-2} \mathrm{~h}^{-1}$ were measured between April and September at the plot. In the boreal forest plot L2, covered with litter, fluxes between $-1.0-0.6 \mathrm{ng} \mathrm{m}^{-2} \mathrm{~h}^{-1}$ were detected. A combined average of $0.9 \pm 1.2 \mathrm{ng} \mathrm{m}^{-2} \mathrm{~h}^{-1}$ was calculated for the forested plots in August 2007. The variances between the sites are likely due to differences in e.g. solar radiation and location, possibly also different plot vegetation and substrate humidity. Deposition was measured during the coldest measurement days (temperature +6.5 and $+10^{\circ} \mathrm{C}$ ). The $24 \mathrm{~h}$ flux measurements conducted every $3 \mathrm{~h}$ at the L1 plot showed a clear diurnal cycle with higher flux during the day than the night. Moreover, the flux pattern followed the air temperature at L1 site (Paper II). At the two other sites, comparison to temperature or other measured parameters is not shown due to small number of measurements. Similar flux values have been reported in background 
forested areas by Kuiken et al. (2008), Lindberg et al. (1998) and Xiao et al. (1991).

Furthermore, our average value $\left(0.9 \mathrm{ng} \mathrm{m}^{-2} \mathrm{~h}^{-1}\right)$ is aligned between the median $\left(0.70 \mathrm{ng} \mathrm{m}^{-2} \mathrm{~h}^{-1}\right)$ and mean $\left(1.22 \mathrm{ng} \mathrm{m}^{-2} \mathrm{~h}^{-1}\right)$ of fluxes reported for background areas in a vast summary article by Agnan et al. (2016). The average $\mathrm{Hg}^{0}$ fluxes around the globe are illustrated in the Fig. 21 adopted from the Agnan et al. (2016) paper.

Three adjacent plots were located at the wetland site and these were covered mostly with moss and grass (Fig. 9D). On three days, fluxes between $-0.3-0.6 \mathrm{ng} \mathrm{m}^{-2} \mathrm{~h}^{-1}$ were measured during daytime (Fig. 20). Studies in boreal wetlands are scarce, however, in a Swedish open mire located in the boreal region, Osterwalder et al. (2017) reported an average emission of $3 \pm 0.5$ $n g \mathrm{~m}^{-2} \mathrm{~h}^{-1}$ during the growing season with a continuous REA system.
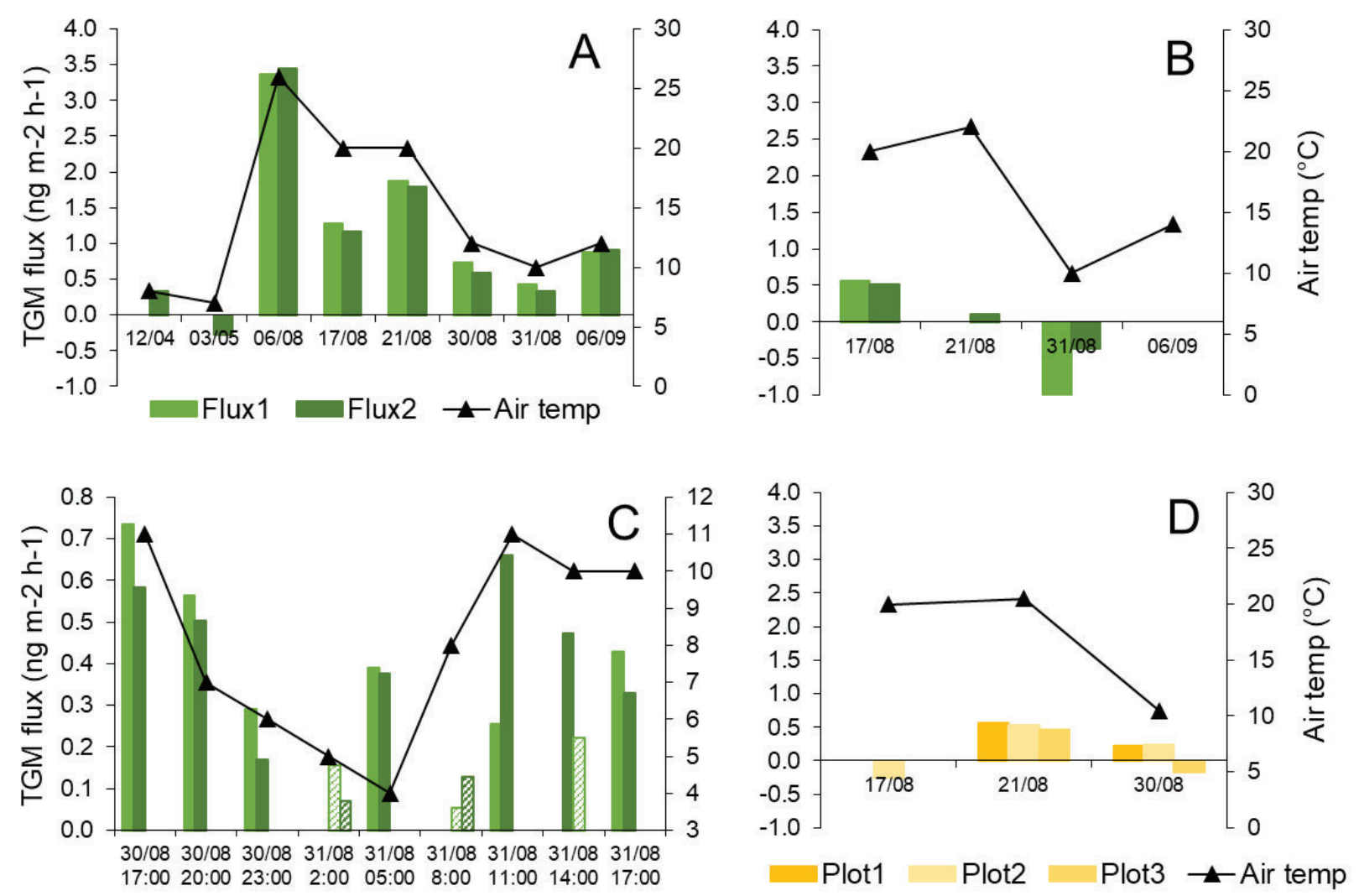

Fig. 20. TGM fluxes in the air-forest floor interface at plot $L 1(A)$, plot $L 2(B)$ together with the $24 \mathrm{~h}$-flux at plot L1 (C) performed sequentially during the measurement campaign at ValkeaKotinen site in summer 2007. In chart C, the hatched bars are flux results with a high uncertainty. In chart D, fluxes at the three collocated wetland plots are shown. The charts are modified from Paper II.

It must be pointed out that our flux measurements were conducted within a period of five months expressing mostly daytime measurements. It should not be interpreted for the whole 
growing season and especially to the year as it is biased in terms of diurnal and seasonal coverage. However, this is rather typical for many flux measurements (Agnan et al., 2016; Fig. $21 \mathrm{C}$ and 21D). With the micrometeorological techniques, year-round continuous measurements are feasible (Fritche et al., 2008; Osterwalder et al., 2016).

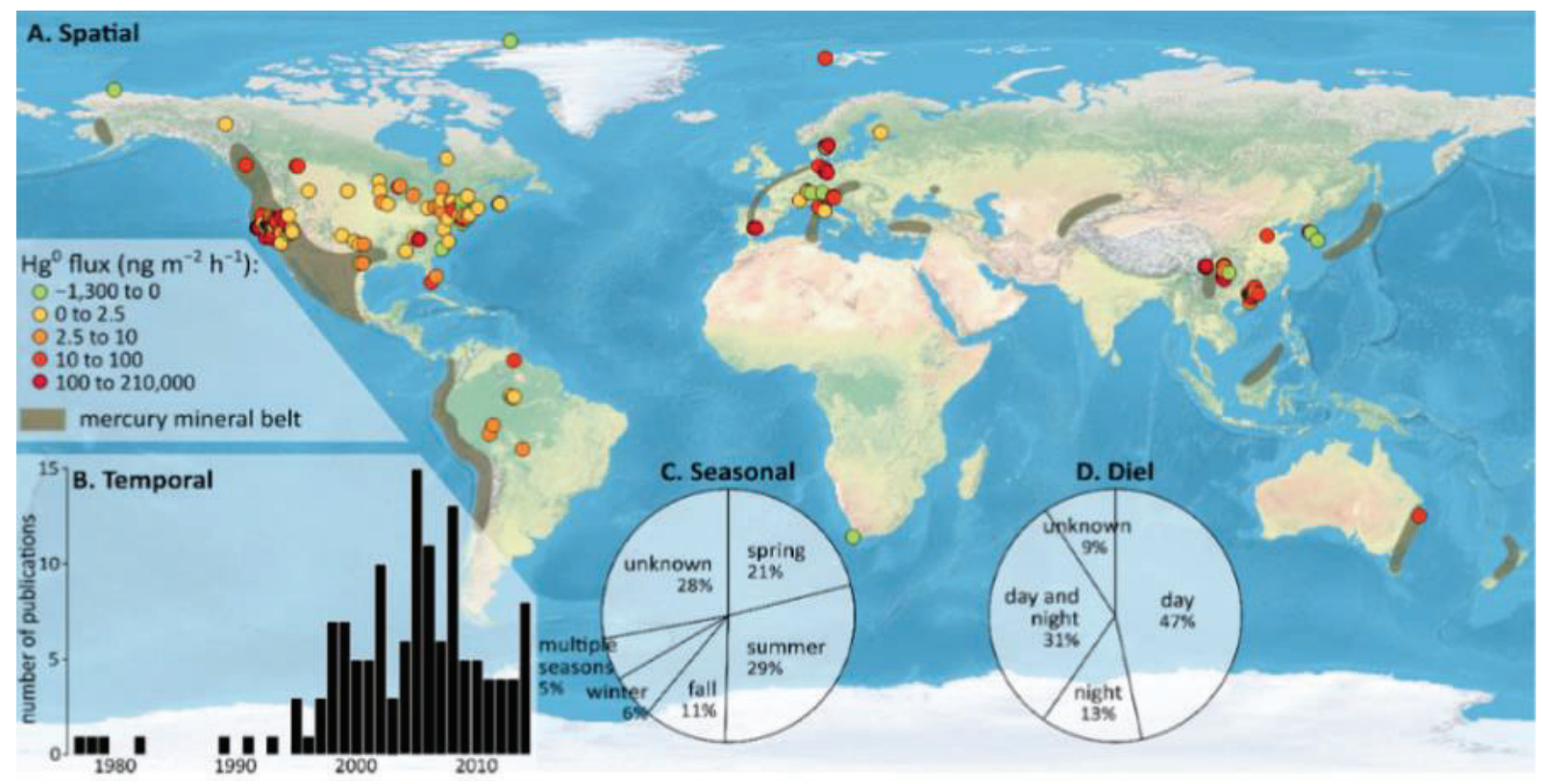

Fig. 21. (A) Average $\mathrm{Hg}^{0}$ fluxes around the globe as reported in the critical review by Agnan et al. (2016) in addition to (B) the number of publications reporting flux results. The proportions of seasonal and diel measurements are shown in $C$ and $D$, respectively. Figure adopted from Agnan et al. (2016). 


\section{REVIEW OF PAPERS AND AUTHOR'S CONTRIBUTION}

Paper I presents a one year dataset of urban TGM concentrations measured continuously at a background site in Helsinki and a mobile measurement campaign for TGM where several urban, industrial and rural areas in Finland were studied. In the Helsinki study, surprisingly high concentrations up to $2500 \mathrm{ng} \mathrm{m}^{-3}$ were detected during a military shooting practise occurring unexpectedly next to the measurement site. In the mobile study, online instrument was placed in a car and measurements were run during driving. Highest concentrations were detected nearby closed chlor-alkali plants currently used by chemical industry and a waste disposal plant. This was the first study to measure TGM in urban areas in Finland, and to our knowledge, the first study to utilize moving car for TGM measurements worldwide. I operated the instruments, validated the data, and wrote the article. My co-authors made the measurement plans, calculated the source areas and commented the manuscript.

Paper II focuses on one background site where we studied the atmospheric and deposition fluxes of mercury in a boreal forest and wetland. Atmospheric fluxes for TGM were measured with a flux chamber method during summer 2007 including day and night-time measurements. Deposition fluxes were measured as a part of the monitoring activities of the site. I operated the TGM instrument coupled to flux chamber, was in charge of the validation of the flux method, validated the atmospheric data and wrote the article. My co-authors helped me with the design of the flux measurements, running the flux measurements, and commented the manuscript.

Paper III is based on the monitoring of atmospheric heavy metals in PM at a sub-arctic Pallas site since 1996 and three other sites in Finland. In the article, data from 1996-2018 is analysed for spatial and temporal trends and sources studied with the positive matrix factorisation. I performed part of the sample analysis with ICP-MS during the years 2004-2009, was in charge of the method and data validations for several years, calculated emission trends and was in charge of writing the article. My co-authors calculated the trends for PM data, modelled the source apportionment with PMF, wrote most of the experimental parts for PM trends and PMF, validated some of the supplementary data, and commented the manuscript.

Paper IV describes ten-year measurements of trace element deposition at the Finnish background sites. The article focuses on spatial and temporal trends, sources of the elements and quality control. I performed part of the sample analysis with ICP-MS during the years 20042007, handled the data, calculated the trends and was the principal author of the paper. My coauthors calculated the $\mathrm{QC}$ results and commented the manuscript.

Paper V is concentrated on the same site as Paper II and studies acidifying compounds and trace elements measured in atmosphere and deposition at the site since 1988. I did part of the sample analysis for acidifying compounds and trace elements in 2003-2009, validated the $\mathrm{Hg}$ deposition method used in 2010-2011, wrote the experimental part for trace elements and made other minor contributions to the manuscript. 


\section{SUMMARY AND IMPLICATIONS}

The primary focus of this thesis was to gain new knowledge on the spatial and temporal trends of atmospheric trace elements, and their sources and fluxes in Finland with the main focus on the background areas.

Atmospheric concentrations and deposition of trace elements was found relatively low and for most elements followed a clear south-to-north degreasing gradient due to differences in distance to the large European source areas, local emissions and length of the snow cover period.

Trends of the trace elements in particulate matter were studied at the sub-arctic Pallas station while trends of deposition were investigated around the country. Between 1996 and 2018, the trace elements in PM showed clear decreases up to $64 \%$, while in the recent decade (20102018), the statistically significant reduction continued for $\mathrm{Cd}, \mathrm{Co}, \mathrm{Ni}, \mathrm{Pb}, \mathrm{V}$, and $\mathrm{Zn}$. Trends for deposition showed mostly decreases reflecting to emission reductions, e.g. $\mathrm{Pb}$ deposition decreased at all sites (55-81\%) in 1998-2018 while statistically significant reductions were observed for As, Cd, and Zn at several sites (38-59 \%, 61-78 \%, 40-50 \%, respectively). In particular, the alarming signal of increasing Cd deposition observed until 2011 at the ValkeaKotinen site was found since to change to a positive development of reducing deposition. Importantly, no statistically significant increasing trends were found for PM.

The sources of trace elements were studied with enrichment factors and the positive matrix factorisation (PMF). EFs grouped the elements to highly anthropogenic origin ( $\mathrm{As}, \mathrm{Cd}, \mathrm{Pb}, \mathrm{Zn}$ ) and fairly crustal origin ( $\mathrm{Al}, \mathrm{Fe}, \mathrm{Cr}, \mathrm{Mn}$ ) with others $(\mathrm{V}, \mathrm{Ni}, \mathrm{Cu})$ in between. A more detailed analysis was performed for the Pallas PM data, with sources separated to five factors: soil, marine, non-ferrous metal smelting, secondary LRT and LRT originating from combustion. Cu, $\mathrm{Ni}, \mathrm{As}$, and Co were mostly attributed to emissions from the Cu-Ni industry in Kola Peninsula, while $\mathrm{Cd}, \mathrm{Cr}, \mathrm{Pb}, \mathrm{V}$, and $\mathrm{Zn}$ were associated to long-range transported combustion emissions. Soil was found the main source for $\mathrm{Al}, \mathrm{Fe}$, and $\mathrm{Mn}$.

An exception to the behaviour of the other atmospheric trace elements was found for TGM, existing mainly in the gaseous form. No statistically significant trends were observed for this toxic pollutant in 2008-2018. Moreover, the spatial pattern in background areas was different with slightly higher concentration in the north. Annual average concentration for TGM was found to range from 1.10 to $1.54 \mathrm{ng} \mathrm{m}^{-3}$. For a nationwide survey, a moving measurement platform was created utilizing a $\mathrm{Hg}$ analyser. Highest short-term concentrations up to $14 \mathrm{ng} \mathrm{m}^{-3}$ were observed close to industrial sites, namely closed chlor-alkali plants currently used for chemical industry, and in the vicinity of a waste disposal plant. However, extremely high ambient concentrations up to $2500 \mathrm{ng} \mathrm{m}^{-3}$ were detected during a shooting practice by the military in Helsinki expected to originate from the $\mathrm{Hg}$ fulminate in the rounds. In the sub-arctic Pallas site, TGM was found to originate mostly from LRT and partly marine sources according to the PMF results.

For the examination of air-terrestrial surface exchange of TGM, a flux method coupling $\mathrm{Hg}$ analyser to a Teflon chamber was built and tested. The fluxes at a boreal forest and wetland were found rather small, $0.9 \pm 1.2 \mathrm{ng} \mathrm{m}^{-2} \mathrm{~h}^{-1}$ and $-0.3-0.6 \mathrm{ng} \mathrm{m}^{-2} \mathrm{~h}^{-1}$, respectively. The 
emission at the forested site was found approximately the same in magnitude as the deposition by precipitation.

To conclude, this thesis contains results of several studies focusing in the atmospheric trace elements, especially mercury, arsenic, cadmium, nickel and lead, all considered priority pollutants with severe health concerns. New information on the trends and sources of a wide variety of elements was gained. After clear reductions in the ambient concentrations since the 1990s, the concentrations of some toxic elements are now levelling off while mercury has shown no change in the last two decades. Furthermore, climate change will likely affect both directly and indirectly the cycles and ambient levels of these elements due to several reasons, e.g. permafrost thawing, increase of forest fires and changes in the use of fossil fuels. This shows the importance of international acts still today such as the UN Minamata Convention focusing on protecting human health from the detrimental effects of mercury. 


\section{REFERENCES}

Aas W. and Bohlin-Nizzetto P. (2017) Heavy metals and POP measurements, 2015. EMEP/CCC-Report 3/2017, O-7726, Kjeller, Norway, ISBN 978-82-425-2906-0 (electronic), ISBN 2464-3920 (paperback),149 pp.

Aas W. and Bohlin-Nizzetto P. (2018) Heavy metals and POP measurements, 2016.

EMEP/CCC-Report 3/2018, O-7726, Kjeller, Norway, ISBN 978-82-425-2947-3 (electronic), ISBN 2464-3920 (paperback), 158 pp.

Aas W. and Bohlin-Nizzetto P. (2019) Heavy metals and POP measurements, 2017. EMEPCCC Report 3/2019, O-7726, Kjeller, Norway, ISBN 978-82-425-2989-3 (electronic), ISBN 2464-3920 (paperback),172 pp.

Abrahim G.M.S. and Parker R.J. (2008) Assessment of heavy metal enrichment factors and the degree of contamination in marine sediments from Tamaki Estuary, Auckland, New Zealand. Environ. Monit. Assess. 136, 227-238.

Agnan Y., Le Dantec T., Moore C.W., Edwards G.C. and Obrist D. (2016) New Constraints on Terrestrial Surface-Atmosphere Fluxes of Gaseous Elemental Mercury Using a Global Database. Environ. Sci. Technol. 50, 507-524.

AMAP/UNEP (2008) The Global Atmospheric Mercury Assessment: Sources, Emissions and Transport. UNEP Chemical Branch, Geneva, Switzerland, 44 pp.

AMAP/UN Environment (2019) Technical Background Report for the Global Mercury Assessment 2018. Arctic Monitoring and Assessment Programme, Oslo, Norway/UN Environment Programme, Chemicals and Health Branch, Geneva, Switzerland. viii +426 pp. including E-Annexes.

Anttila P. and Tuovinen J.-P. (2010) Trends of primary and secondary pollutant concentrations in Finland in 1994-2007. Atmos. Environ. 44, 30-41.

Areskoug H. (2016) An Equivalence Study of PM10 Instruments at a Road Traffic Site in Stockholm Spring 2012. ACES Report 4, 67 pp.

Barbieri M. (2016) The Importance of Enrichment Factor (EF) and Geoaccumulation Index (Igeo) to Evaluate the Soil Contamination. J. Geol. Geophys. 5, 237.

Bond, T.C., Streets D.G., Yarber K.F., Nelson S.M., Woo J.-H. and Klimont Z. (2004) A technology-based global inventory of black and organic carbon emissions from combustion. $J$. Geophys. Res. 109, D14203.

Carpi A., Frei A., Cocris d., McCloskey R., Contreras E. and Ferguson K. (2007) Analytical artifacts produced by a polycarbonate chamber compared to a Teflon chamber for measuring surface mercury fluxes. Anal. Bioanal. Chem. 388, 361-365.

Carslaw D.C. and Ropkins K. (2012) Openair — an R package for air quality data analysis. Environ. Modell. Softw. 27-28, 52-61. 
Carslaw D.C. (2015) The openair manual - open-source tools for analysing air pollution data. Manual for version 1.1-4, King's College London.

Dastoor A.P. and Durnford D.A. (2014) Arctic Ocean: Is It a Sink or a Source of Atmospheric Mercury? Environ. Sci. Techn. 48, 1707-1717.

Duffus JH (2002) "Heavy metals"—a meaningless term? Pure Appl. Chem. 74, 793-807.

Durnford D., Dastoor A., Figueras-Nieto D. and Ryjkov A. (2010) Long range transport of mercury to the Arctic and across Canada. Atmos. Chem. Phys. 10, 6063-6086.

Dragovic S. and Mihailovic N. (2009) Analysis of mosses and topsoils for detecting sources of heavy metal pollution: multivariate and enrichment factor analysis. Environ. Monit. Assess. 157, 383-390.

Eckley C.S., Gustin M., Lin C.-J., Li X. and Miller M.B. (2010) The influence of dynamic chamber design and operating parameters on calculated surface-to-air mercury fluxes. Atmos. Environ. 44, 194-203.

EEA (2019a) European Union emission inventory report 1990-2017 under the UNECE Convention on Long-range Transboundary Air Pollution (LRTAP). EEA Report No 08/2019, European Environment Agency, Copenhagen. ISBN 978-92-9480-078-7, ISSN 1977-8449, 148 pp.

EEA (2019b) Air quality in Europe - 2019 report. EEA Report No 10/2019. European Environment Agency, Luxembourg. ISBN 978-92-9480-088-6, ISSN 1977-8449, 104 pp.

EMEP (2001) EMEP Manual for Sampling and Chemical Analysis. EMEP/CCC-Report 1/95, (revision 1/2014 available in https://projects.nilu.no//ccc/manual/), 303 pp.

EN 14902:2005. Ambient air quality - Standard method for the measurement of $\mathrm{Pb}, \mathrm{Cd}, \mathrm{As}$ and $\mathrm{Ni}$ in the PM10 fraction of suspended particulate matter. Standard developed by CEN, 58 pp.

EN 15841:2010. Ambient air quality - Standard method for determination of arsenic, cadmium, lead and nickel in atmospheric deposition. Standard developed by CEN, 33 pp.

EN 15853:2010. Ambient air quality - Standard method for the determination of mercury deposition. Standard developed by CEN, $33 \mathrm{pp}$.

EPA (2016) Review of the National Ambient Air Quality Standards for Lead. Federal Register, 81, 201, 71906-71943.

EU (2004) Directive 2004/107/EC of the European Parliament and of the Council of 15 December 2004 relating to arsenic, cadmium, mercury, nickel and polycyclic aromatic hydrocarbons in ambient air. Off J 2005, L 23, 3-16, URL: http://eur-

lex.europa.eu/LexUriServ/LexUriServ.do?uri=OJ:L:2005:023:0003:0016:EN:PDF (Jan, 2020).

EU (2008) Directive 2008/50/EC of the European Parliament and of the Council of 21 May 2008 on ambient air quality and cleaner air for Europe. Off J 2008, L 152, 1-44, URL: http://eurlex.europa.eu/legal-content/EN/TXT/PDF/?uri=CELEX:32008L0050\&from=EN (Jan, 2020).

EU (2015) Commission Directive (EU) 2015/1480 of 28 August 2015 amending several annexes to Directives 2004/107/EC and 2008/50/EC of the European Parliament and of the Council 
laying down the rules concerning reference methods, data validation and location of sampling points for the assessment of ambient air quality. Off $\mathrm{J} 2015$, L 226, 4-11, URL: https://eurlex.europa.eu/eli/dir/2015/1480/oj (Jan, 2020).

Finnish Environment Institute (2020) Air pollutant emissions. Website in Finnish. URL: http://aedb.apef-library.fi/index.php (Feb, 2020).

Fritsche J., Obrist D., Zeeman M.J., Conen F., Eugster W. and Alewell C. (2008) Elemental mercury fluxes over a sub-alpine grassland determined with two micrometeorological methods. Atmos. Environ. 42, 2922-2933.

Gilbert RO. (1987) Statistical methods for environmental pollution monitoring. New York: Van Norstrand Reinhold, $320 \mathrm{pp}$.

Gustin M. (2012) Exchange of mercury between the atmosphere and terrestrial ecosystems. In: Liu G., Cai Y. and O'Driscoll N., editors. Environmental chemistry and toxicology of mercury. New Yersey, John Wiley \& Sons Inc., ISBN 978-0-470-57872-8, p. 423-452.

Harris R.C., Rudd J.W.M, Amyot M., Babiarz C.L., Beaty K.G., Blanchfield P.J., Bodaly R.A., Branfireun B.A., Gilmour C.C., Graydon J.A., Heyes A., Hintelmann H., Hurley J.P., Kelly C.A., Krabbenhoft D.P., Lindberg S.E., Mason R.P., Paterson M.J., Podemski C.L., RobinsonA., Sandilands K.A., Southworth G.R., St. Louis V.L. and Tate M.T. (2007) Whole-ecosystem study shows rapid fish-mercury response to changes in mercury deposition. Proc. Natl. Acad. Sci. 104, 42, 16586-16591.

HELCOM (2014) Convention on the Protection of the Marine Environment of the Baltic Sea Area (Helsinki Convention). Baltic Marine Environment Protection Commission. 44 pp. URL: https://helcom.fi/about-us/convention/ (Jan, 2020).

Hellén H., Hakola H., Pystynen K.-H., Rinne J. and Haapanala S. (2006) C2-C10 hydrocarbon emissions from a boreal wetland and forest floor. Biogeosciences 3, 167-174.

Hellén H., Praplan A.P., Tykkä T., Ylivinkka I., Vakkari V., Bäck J., Petäjä T., Kulmala M. and Hakola H. (2018) Long-term measurements of volatile organic compounds highlight the importance of sesquiterpenes for the atmospheric chemistry of a boreal forest. Atmos. Chem. Phys. 18, 13839-13863.

Hyvärinen A.P., Kolmonen P., Kerminen V.M., Virkkula A., Leskinen A., Komppula M., Hatakka J., Burkhart J., Stohl A., Aalto P., Kulmala M., Lehtinen K.E.J., Viisanen Y., Lihavainen H. (2011) Aerosol black carbon at five background measurement sites over Finland, a gateway to the Arctic. Atmos. Environ. 45, pp. 4042-4050.

Jalkanen L. and Häsänen E. (1996) Simple Method for the Dissolution of Atmospheric Aerosol Samples for Analysis by Inductively Coupled Plasma Mass Spectrometry. J. Anal. At. Spectrom. 11(5), 365-369.

Jiskra M., Sonke J.E., Obrist D., Bieser J., Ebinghaus R., Lund Myhre C., Aspmo Pfaffhuber K., Wängberg I., Kyllönen K., Worthy D., Martin L.G., Labuschagne C., Mkololo T., Ramonet M., Magand O. and Dommergue A. (2018) A vegetation control on seasonal variations in global atmospheric mercury concentrations. Nature Geoscience 11, 244-250. 
Kyllönen K. (2019) Total gaseous mercury and mercury deposition measurements in Finland. Abstract Volume of the 14th International Conference on Mercury as a Global Pollutant, September 8-13, 2019, Krakow, Poland, 250 pp.

Lelieveld J., Evans J.S., Fnais M., Giannadaki D. and Pozzer A. (2015) The Contribution of Outdoor Air Pollution Sources to Premature Mortality on a Global Scale. Nature 525, 367-371.

Lin C.-J., Singhasuk P. and Pehkonen S.O. (2012) Atmospheric chemistry of mercury. In: Liu G., Cai Y. and O'Driscoll N., editors. Environmental chemistry and toxicology of mercury. New Yersey, John Wiley \& Sons Inc., ISBN 978-0-470-57872-8, pp. 113-153.

Liu G., Cai Y., O'Driscoll N., Feng X., Jiang G. (2012) Overview of Mercury in the Environment. In: Liu G., Cai Y., O’Driscoll N., editors. Environmental Chemistry and Toxicology of Mercury. New Jersey, Wiley, pp. 1-12.

Makkonen U., Hellen H., Anttila P. and Ferm M. (2010) Size distribution and chemical composition of airborne particles in south-eastern Finland during different seasons and wildfire episodes in 2006. Sci. Total Environ. 408, 644-651.

Mason B. (1966) Principles of geochemistry. New York: John Wiley \& Sons Inc, ISBN 0-47108513-8, 329 pp.

Nerentorp M., Kyllönen K., Wängberg I. and Kuronen P. (2013) Speciation measurements of airborne mercury species in northern Finland; evidence for long range transport of air masses depleted in mercury. E3S Web Conf. 1, 27003.

Nguyen Q.T., Skov H., Sørensen L.L., Jensen B.J., Grube A.G., Massling A., Glasius M., and Nøjgaard J.K. (2013) Source apportionment of particles at Station Nord, North East Greenland during 2008-2010 using COPREM and PMF analysis. Atmos. Chem. Phys. 13, 35-49.

Nriagu J.O. (1989) A global assessment of natural sources of atmospheric trace metals. Nature 338, 47-49.

OSPAR (1992) Convention for the Protection of the Marine Environment of the North-East Atlantic, 33pp. https://www.ospar.org/convention (Jan, 2020).

Osterwalder S., Fritsche J., Alewell C., Schmutz M., Nilsson M. B., Jocher G., Sommar J., Rinne J. and Bishop K. (2016) A dual-inlet, single detector relaxed eddy accumulation system for longterm measurement of mercury flux. Atmos. Meas. Tech. 9, 509-524.

Osterwalder S., Bishop K., Alewell C., Fritsche J., Laudon H., Åkerblom S. and Nilsson M.B. (2017) Mercury evasion from a boreal peatland shortens the timeline for recovery from legacy pollution. Nature Scientific Reports 7, 16022.

Paatero J., Dauvalter V., Derome J., Lehto J., Pasanen J., Vesala T., Miettinen J., Makkonen U., Kyrö E.-M., Jernström J., Isaeva L. and Derome K. (2008) Effects of Kola Air Pollution on the Environment in the Western Part of the Kola Peninsula and Finnish Lapland - Final Report. ISBN 978-951-697-686-3, ISNN 0782-6079, 26 pp.

Paatero P. and Tapper U. (1994) Positive matrix factorization: A non-negative factor model with optimal utilization of error estimates of data values. Environmetrics 5, 111-126. 
Paatero P. (1997) Least squares formulation of robust non-negative factor analysis. Chemom. Intell. Lab. Sys. 37, 23-35.

Paatero P., Eberly S., Brown S.G. and Norris G.A. (2014) Methods for estimating uncertainty in factor analytic solutions. Atmos. Meas. Tech. 7, 781-797.

Pachon J.E., Weber R.J., Zhang X., Mulholland J.A. and Russell A.G. (2013) Revising the use of potassium (K) in the source apportionment of PM2.5. Atmos. Pollut. Res. 4, 14-21.

Pacyna J.M. and Pacyna E.G. (2001) An assessment of global and regional emissions of trace metals to the atmosphere from anthropogenic sources worldwide. Environ. Rev. 9, 269-298.

Pacyna E.G., Pacyna J.M., Fudala J., Strzelecka-Jastrzab E., Hlawiczka S., Panasiuk D., Nitter S., Pregger T., Pfeiffer H. and Friedrich R. (2007) Current and future emissions of selected heavy metals to the atmosphere from anthropogenic sources in Europe. Atmos. Environ. 41, 8557-8566.

Pacyna E.G., Pacyna J.M., Sundseth K., Munthe J., Kindbom K., Wilson S., Steenhuisen F., Maxson P. (2010) Global emission of mercury to the atmosphere from anthropogenic sources in 2005 and projections to 2020. Atmos. Environ. 44, 2487-2499.

Pakkanen T.A., Kerminen V.-M., Korhonen C.H., Hillamo R.E., Aarnio P., Koskentalo T. and Maenhaut W. (2001) Use of atmospheric elemental size distributions in estimating aerosol sources in the Helsinki area. Atmos. Environ. 35, 5537-5551.

Prüss-Ustün A., Wolf J., Corvalán C., Bos R. and Neira M. (2016) Preventing disease through healthy environments. A global assessment of the burden of disease from environmental risks. World Health Organization, France. ISBN 978-92-4-156519-6, 76 pp.

Risch M.R., Gay D.A., Fowler K.K., Keeler G.J., Backus S.M., Blanchard P., Barres J.A., Dvonch J.T. (2012) Spatial patterns and temporal trends in mercury concentrations, precipitation depths, and mercury wet deposition in the North American Great Lakes region, 2002-2008. Environ. Pollut. 161, 261-271.

Rolph G., Stein A. and Stunder B. (2017) Real-time Environmental Applications and Display sYstem: READY. Environ. Modell. Softw. 95, 210-228.

Ruoho-Airola T., Anttila P., Hakola H., Ryyppö T. and Tuovinen J.-P. (2015) Trends in the bulk deposition and atmospheric concentration of air pollutants in the Finnish integrated monitoring catchment Pallas during 1992-2012. Boreal Env. Res. 20, 553-569.

Salmi T., Määttä A., Anttila P., Ruoho-Airola T. and Amnell T. (2002) Detecting trends of annual values of atmospheric pollutants by the Mann-Kendall test and Sen's slope estimates - the Excel template application MAKESENS. Publications on air quality, vol. 31, Report Code FMIAQ-31, ISBN 951-697-563-1, 35 pp.

von Schneidemesser E., Schauer J.J., Hagler G.S.W. and Bergin M.H. (2009) Concentrations and sources of carbonaceous aerosol in the atmosphere of Summit, Greenland. Atmos.

Environ. 43, 4155-4162.

Schroeder W.H., Anlauf K.G., Barrie L.A., Lu J.Y., Steffen A., Schneeberger D.R. and Berg T. (1998) Arctic springtime depletion of mercury. Nature 394, 331-332. 
Schroeder W. and Munthe J. (1998) Atmospheric mercury-an overview. Atmos. Environ. 32, 809-822.

Selin N. (2009) Global Biogeochemical Cycling of Mercury: A Review. Annu. Rev. Env. Resour. 34, 43-63.

Sharma S., Ishizawa M., Chan D., Lavoué D., Andrews E., Eleftheriadis K. and Maksyutov S. (2013) 16-year simulation of Arctic black carbon: Transport, source contribution, and sensitivity analysis on deposition. JGR Atmospheres 118, 943-964.

Slemr F., Brunke E.-G., Ebinghaus R., Temme C., Munthe J., Wängberg I., Schroeder W., Steffen A. and Berg T. (2003) Worldwide trend of atmospheric mercury since 1977. Geophys. Res. Lett. 30, 1516.

Song F. and Gao Y. (2009) Chemical characteristics of precipitation at metropolitan Newarkin the US East Coast. Atmos. Environ. 43, 4903-4913.

Steffen A., Douglas T., Amyot M., Ariya P., Aspmo K., Ber, T., Bottenheim J., Brooks S., Cobbett F, Dastoor A., Dommergue A., Ebinghaus R., Ferrari C., Gardfeldt K., Goodsite E., Lean D., Poulain A. Scherz C., Skov H., Sommar J. and Temme C. (2008) A synthesis of atmospheric mercury depletion event chemistry linking atmosphere, snow and water. Atmos. Chem. Phys. 8, 1445-1482.

Stein A.F., Draxler R.R., Rolph G.D., Stunder B.J.B., Cohen M.D. and Ngan F. (2015) NOAA's Hysplit Atmospheric Transport and Dispersion Modeling System. Bull. Am. Meteorol. Soc. 96, 2059-2077.

Stohl A., Wotawa G., Seibert P. and Kromp-Kolb H. (1995) Interpolation errors in wind fields as a function of spatial and temporal resolution and their impact on different types of kinematic trajectories. J. Appl. Meteor. 34, 2149-2165.

Stohl A. and Seibert P. (1998) Accuracy of trajectories as determined from the conservation of meteorological tracers. Q. J. Roy. Met. Soc. 124, 1465-1484.

Suvarapu L.N. and Baek S.O. (2017) Determination of heavy metals in the ambient atmosphere: a review. Toxicol. Ind. Health 33, 79-96.

Tchounwou P.B., Yedjou C.G., Patlolla A.K. and Sutto D.J. (2012) Heavy Metals Toxicity and the Environment. Experientia suppl. 101, 133-164.

Timonen H., Teinilä K., Aurela M., Reyes F., Vásquez Y., Bloss M., Oyol P., Hillamo R., Asmi E. and Saarikoski S. (2018) Sources and composition of particulate matter in boreal arctic environment next to an active mining area. Boreal Env. Res. 23, 105-125.

Tunved P., Hansson H.-C., Kerminen V.-M., Ström J., Dal Maso M., Lihavainen H., Viisanen Y., Aalto P.P., Komppula M. and Kulmala M. (2006) High natural aerosol loading over Boreal forests. Science 312, 261-263.

UNECE (1998) The 1998 Aarhus Protocol on Heavy Metals. United Nations Economic Commission for Europe. 33 pp. URL: http://www.unece.org/env//rtap/hm_h1.html (Jan, 2020)

UN Environment (2017) Minamata Convention on Mercury - Text and Annexes. United Nations Environment Programme. 72 pp. URL: http://www.mercuryconvention.org/ (Jan, 2020) 
Vestenius M., Leppänen S., Anttila P., Kyllönen K., Hatakka J., Hellén H., Hyvärinen A. and Hakola H. (2011) Background concentrations and source apportionment of polycyclic aromatic hydrocarbons in South-Eastern Finland. Atmos. Environ. 45, 3391-3399.

Virkkula A., Aurela M., Hillamo R., Mäkelä T., Pakkanen T., Kerminen V.-M., Maenhaut W., Francois F. and Cafmeyer J. (1999) Chemical composition of atmospheric aerosol in the European subarctic: Contribution of the Kola Peninsula smelter areas, central Europe, and the Arctic Ocean. J. Geophys. Res. Atmos. 104, D19, 23681-23696.

Visser S., Slowik J.G., Furger M., Zotter P., Bukowiecki N., Dressler R., Flechsig U., Appel K., Green D., Tremper A.H., Young D.E., Williams P.I., Allan J.D., Herndon S., Williams L.R., Mohr C., Xu L., Ng N., Detournay A., Barlow J., Halios C..H, Fleming Z.L., Baltensperger U.,Prevot A.S.H. (2015) Kerb and urban increment of highly time-resolved trace elements in PM10, PM2.5 and PM1.0 winter aerosol in London during ClearfLo 2012. Atmos. Chem. Phys. 14, 2367-2386.

Waldén J., Waldén T., Laurila S. and Hakola H. (2017) Demonstration of the equivalence of PM2.5 and PM10 measurement methods in Kuopio 2014-2015. Finnish Meteorological institute Reports, 1:2017. ISBN 978-952-336-010-5, 135 pp.

Wiersma G.B. and Davidson C.I. (1986) Trace metals in the atmosphere of remote areas. In: Nriagu J.O., Davidson C.I., editors. Toxic metals in the atmosphere. New York, John Wiley \& Sons Inc., ISBN 0-471-82654-5, p. 201-66.

Winiger P., Andersson A., Eckhardt S., Stohl A. and Gustafsson Ö. (2016) The sources of atmospheric black carbon at a European gateway to the Arctic. Nature communications 7 , 12776.

WHO (2018) Ambient (outdoor) air pollution. Key facts. Fact sheet available in https://www.who.int/news-room/fact-sheets/detail/ambient-(outdoor)-air-quality-and-health (Jan, 2020)

Wängberg I. and Munthe J. (2001) Atmospheric mercury in Sweden, northern Finland and northern Europe. Results from national monitoring and European research. IVL Swedish Environmental Research Institute. IVL report B1399, 16 pp.

Yamauchi H. and Fowler B.A. (1994) Toxicity and metabolism of inorganic and methylated arsenicals. In: Nriagu JO, editor. Arsenic in the Environment, Part II: Human Health and Ecosystem Effects. New York: Wiley, pp. 35-43. 



\title{
Nationwide survey of airborne mercury in Finland
}

\author{
Katriina Kyllönen*, Jussi Paatero, Tuula Aalto and Hannele Hakola
}

\begin{abstract}
Finnish Meteorological Institute, P.O. Box 503, Fl-00101 Helsinki, Finland ( ${ }^{*}$ corresponding author's e-mail: katriina.kyllonen@fmi.fi)
\end{abstract}

Received 5 Aug. 2013, final version received 8 Apr. 2014, accepted 9 May 2014

Kyllönen, K., Paatero, J., Aalto, T. \& Hakola, H. 2014: Nationwide survey of airborne mercury in Finland. Boreal Env. Res. 19 (suppl. B): 355-367.

Continuous measurements of total gaseous mercury (TGM) at an urban background station in Helsinki, Finland, were performed in 2006-2007. Additionally, a one-month campaign to measure TGM continuously from a moving car was organized in 2007, when several cities and industrial areas around Finland were surveyed. In Helsinki, a one-year average of $1.54 \pm 0.20 \mathrm{ng} \mathrm{m}^{-3}$ was measured, which is about the global average for this persistent pollutant. The highest concentrations, up to $2500 \mathrm{ng} \mathrm{m}^{-3}$, were measured during firing practice that took place next to the station. Seasonal and diurnal variation was studied, and trajectory maps were constructed to analyze mercury source regions. In the mobile measurement campaign, concentrations varying between 1.0 and $13.8 \mathrm{ng} \mathrm{m}^{-3}$ were measured. The highest concentrations (above $10 \mathrm{ng} \mathrm{m}^{-3}$ ) were recorded close to former chlor-alkali plants that used mercury in their electrolytic production process.

\section{Introduction}

Mercury is a naturally-occurring element that is ubiquitous around the globe. It is a long-lived pollutant that can bio-accumulate in ecosystems and have adverse effects on human health, especially on children and the developing foetus. In the atmosphere, mercury is mostly present in its elemental form, $\mathrm{Hg}^{0}$. Fish consumption is the primary source of mercury for many populations. Due to bacterial activity in waterbodies, inorganic mercury can be transformed into highly toxic methyl mercury, and end up in the fish humans consume. Thus, food safety authorities such as the US Food and Drug Administration and the Finnish Food Safety Authority (Evira) issue consumer advisories about mercury in fish and shellfish. Recently, mercury has gained much international attention due to the launch of new legislation (European Parliament, Council 2004), concerns in the Arctic (AMAP 2011) and, most recently, the UNEP Global Legally Binding Treaty on Mercury that is open for signature by governments in October 2013.

At the global scale, there are several anthropogenic sources of mercury, mainly coal combustion, small-scale gold mining, manufacturing of non-ferrous metals, cement production, waste disposal and caustic soda production (Pirrone et al. 2010). In Europe, major contributors are the combustion of coal in power plants and residential heat furnaces $(\sim 50 \%)$, the production of caustic soda using the $\mathrm{Hg}$ cell process (17\%) and cement production (13\%) (Pacyna et al. 2006b). Mercury can also be emitted from natural sources such as waterbodies, soil and vegetation. Reemission of earlier-deposited mercury affects the mercury budget greatly, although it is extremely 
difficult to quantify (Pacyna et al. 2006a). It has been estimated that natural sources plus re-emission account for two-thirds of total $\mathrm{Hg}$ emissions, while anthropogenic sources explain the remaining one-third (Pirrone et al. 2010). In Finland, combustion in the energy, transfer and manufacturing industries and production processes were the main $\mathrm{Hg}$ emission sources in the 1990s (Melanen et al. 1999, Mukherjee et al. 2000). Nowadays according to the national pollutant emission database, a single steel-making plant, numerous power plants and the national chemical industry are the main $\mathrm{Hg}$ emitters. As estimated by Travnikov et al. (2012), domestic (vs. foreign) $\mathrm{Hg}$ emission sources contribute about one-third of the mercury anthropogenic deposition in Finland.

In urban environments, TGM concentrations were measured at different locations in e.g. Canada, China, Korea, Mexico, Sweden, Taiwan and the USA (Feng et al. 2004, Poissant et al. 2005, Stamenkovic et al. 2007, Kim et al. 2009, Li et al. 2009, Peterson et al. 2009, Rutter et al. 2009, Liu et al. 2010, Huang et al. 2012, Zhu et al.2012, Jen et al.2013). Measurements close to anthropogenic point sources were carried out to a lesser degree, but studies close to chlor-alkali plants, in particular, were made in Belgium, France, Sweden and the USA (Dommergue et al. 2002, Wängberg 2003, 2005, Landis et al. 2004, De Temmerman et al. 2007). However, data from urban and industrial environments in Europe are scarce; moreover, published data on Finnish background or urban mercury concentrations in the atmosphere are almost nonexistent.

This paper describes the TGM levels the Finnish public is exposed to in its daily life. Measurements were conducted for one year at an urban background station and also in several cities and industrial areas around the country using a mobile measurement method. These data sets for TGM in Finland are by far the largest so far published. Mobile air quality measurements had been conducted earlier. In Finland, studies with a "Sniffer" Mobile Laboratory Vehicle were carried out several times, but these campaigns did not measure mercury (Pirjola et al. 2004, 2009, 2012). To our knowledge, this is the first time TGM was measured continuously from a moving car.

\section{Experimental sites and methods}

\section{Measurement sites}

Total gaseous mercury in the ground-level air was measured between September 2006 and August 2007 at the Isosaari weather station $\left(60^{\circ} 06^{\prime} 16^{\prime \prime} \mathrm{N}, \quad 25^{\circ} 04^{\prime} 05^{\prime \prime} \mathrm{E}\right.$; WMO number 02988). The station is located on the Baltic Sea island of Isosaari about $8 \mathrm{~km}$ south-east from the shore of the Helsinki city centre (Fig. 1). The island (76 hectares) is covered mainly by coniferous forests. However, the station is located on a rocky cape with hardly any vegetation. Isosaari is governed by the Finnish Defence Forces and is closed to the public. The operation of the garrison, with occasional firing exercises, is practically the only human activity on the island. The site is categorised as an urban background station for Helsinki. The weather station was also operated by the military during the measurement period.

A nation-wide survey of the total gaseous mercury in Finland was accomplished with a one-month mobile measurement campaign (henceforth referred to as the MMC) in 2007. All major population centres and a large number of industrial sites were surveyed. The industrial sites visited included e.g. former chlor-alkali plants, power plants and pulp and paper mills.

\section{Sampling}

Sampling was conducted using a Tekran 2537A mercury analyser. This instrument collects samples in turns into two gold cartridges at 5-minute intervals, and analyses them continuously. While one cartridge is collecting a sample, the other is being desorbed and the mercury in the sample is analysed by atomic fluorescence spectrometry (AFS). The analyser collects only total gaseous mercury, not particles: these are removed from the sample flow with a PTFE filter. The method has a detection limit of $0.1 \mathrm{ng} \mathrm{m}^{-3}$, repeatability of $2 \%$ and a measurement uncertainty of $10 \%$. The analyser was calibrated daily with its internal permeation source at the Isosaari site. During the MMC, the analyser was calibrated at the start of each measurement day and, if needed, later 
during the day. Even in the car, the calibrations were stable with a relative standard deviation of $5 \%$. During the MMC, only two routine calibrations were omitted from the whole data set but later on the same day they were successfully carried out. A detailed description of the instrument can be found in Kyllönen et al. (2012). This instrument model was used successfully at a number of locations around the world, and has been found to give results comparable to those from other methods (Ebinghaus et al. 1999).

During the MMC, the Tekran mercury analyser described above was installed in a car. This measuring method does not necessarily give information about the typical TGM concentration level in the studied area, since the data are based on 5-min samples provided by Tekran. It rather gives valuable information about possible source areas around the country in a reasonably short time, and gives an indication of the $\mathrm{Hg}$ pollution level in various parts of Finland. When a possible source was identified, measurements were conducted in the nearby area for an extended time. Electrical power for the equipment was obtained from the car battery via a $12 \mathrm{VDC} / 230 \mathrm{VAC}$ inverter. The sampling line inlet was above the car roof ahead of the position of the car's exhaust pipe. Thus ingestion of exhaust fumes into the analyser was prevented when the car was moving.

\section{Concentration fields}

Trajectories, i.e. the paths of air parcels arriving at Helsinki, were utilized in an analysis of the long-range transport of mercury. They were calculated five days backwards using a threedimensional kinematic FLEXTRA trajectory model (e.g. Stohl et al. 1995, Stohl and Seibert 1998), using numerical meteorological data from the European Centre for Medium-Range Weather Forecasts (ECWMF) MARS database. Trajectories were calculated at three-hour intervals, their arrival level at Helsinki being $950 \mathrm{hPa}$. Trajectories were applied to construct maps of mercury source regions. In this method, the concentration observations are distributed along the corresponding trajectory paths (Stohl 1996). In the first step, the measured TGM concentrations are

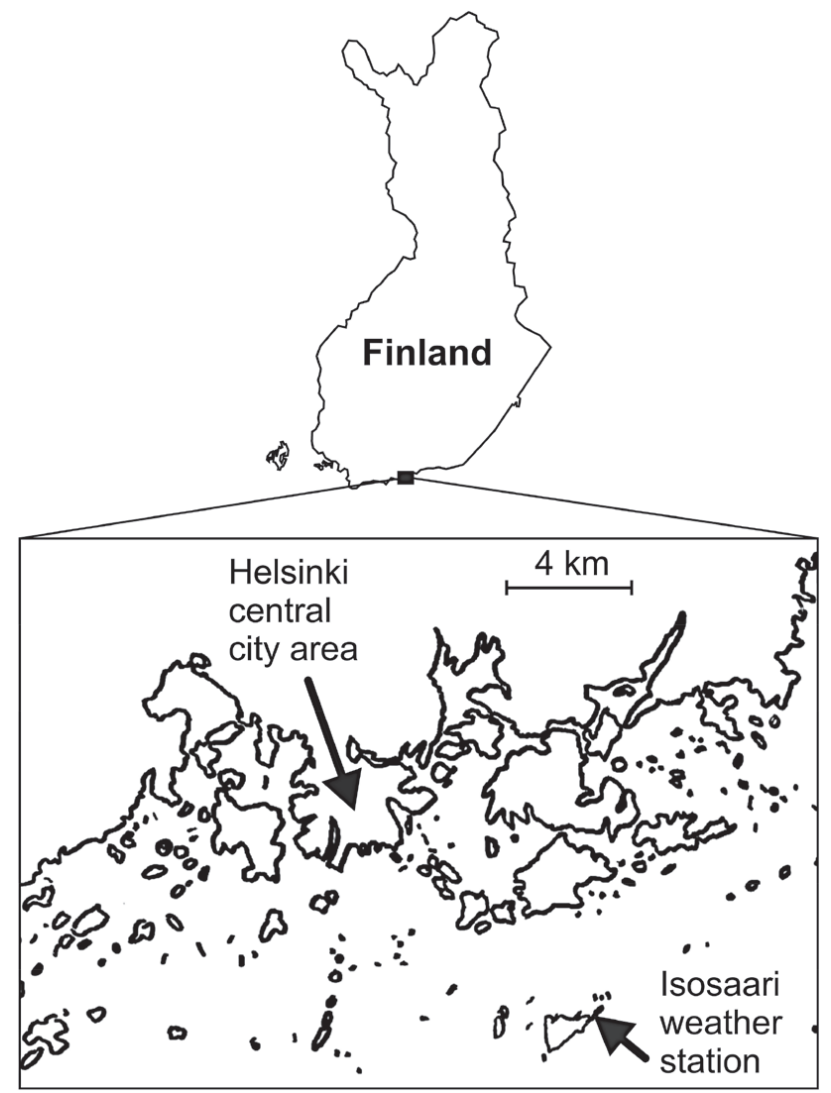

Fig. 1. Location of the measurement site at Isosaari.

distributed evenly along the path and averaged at every grid point crossed by several paths and thus multiple concentration values. Concentrations are scaled and redistributed again along the trajectory path following the methods developed by Stohl (1996). Redistribution continues until the change in the resulting concentration field is negligible. Finally, a chart is obtained where high-concentration regions refer to multiple occasions of air masses with elevated concentrations passing that region before arriving at Helsinki. Trajectory altitudes $<1000 \mathrm{~m}$ were included in order to allow only transport inside the boundary layer and continuous contact with the surface sources.

\section{Results and discussion}

\section{One-year study of TGM in Helsinki}

The hourly TGM concentrations in the ambient air at the urban background station in Helsinki (Fig. 2) remained mostly close to the global background value of $1.7 \mathrm{ng} \mathrm{m}^{-3}$ for the north- 


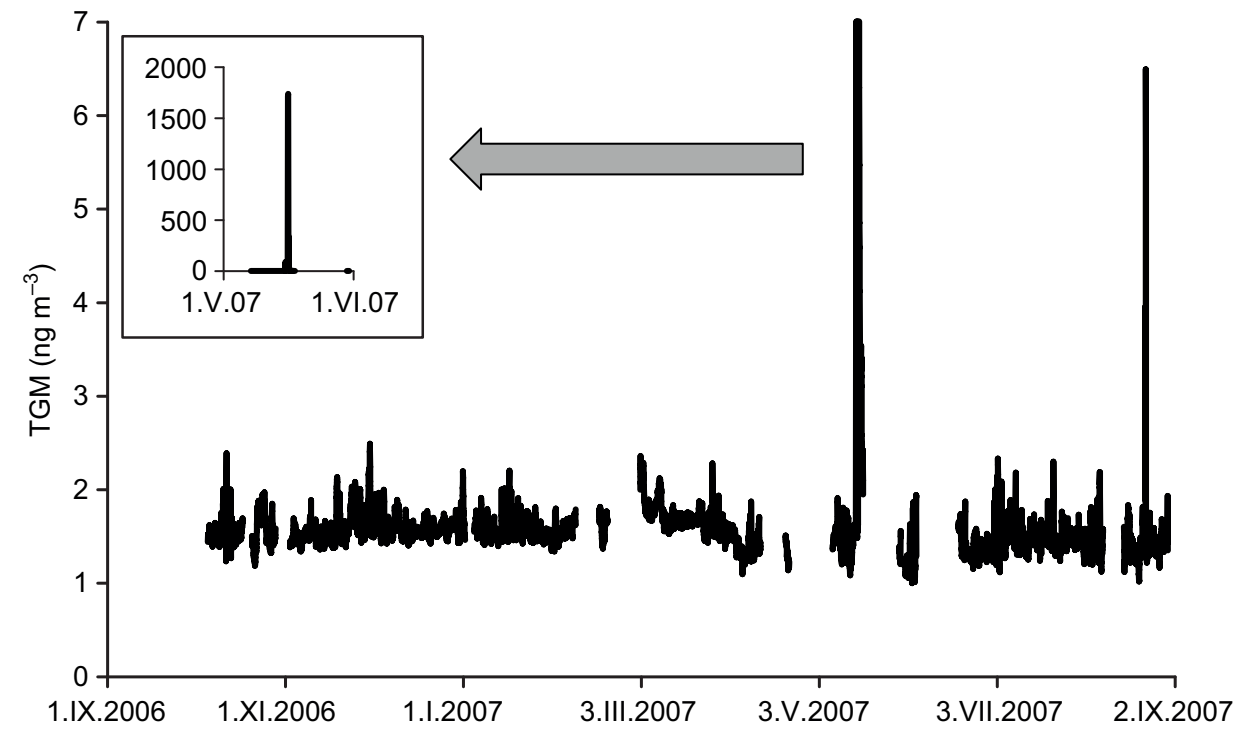

Fig. 2. Hourly TGM concentrations in Helsinki. Two peaks exceeding the scale, and presented in the smaller figure, represent data during the firing practice. ern hemisphere (Slemr et al. 2003). During the campaign, the average hourly TGM concentration was $1.54 \pm 0.20 \mathrm{ng} \mathrm{m}^{-3}$. Closeness to both local pollution sources (the city of Helsinki) and neighbouring countries with high mercury emissions are reflected in the frequent peaks in the data. Hourly concentrations above $3 \mathrm{ng} \mathrm{m}^{-3}$ were seen only on three days during the project.

In August, a pollution plume arrived from the east, resulting in short-term concentrations of up to $14.9 \mathrm{ng} \mathrm{m}^{-3}$ and an hourly concentration of up to $6.5 \mathrm{ng} \mathrm{m}^{-3}$. According to NOAA HYSPLIT backward trajectories, the air masses arrived from Russia and northeast Estonia, and reached mainland Helsinki just before reaching the station. In Estonia, a power generation complex with the world's largest oil-shale-fired thermal power plants is located in the northeastern part of the country. Oil shale burning is known to emit significant amounts of $\mathrm{Hg}$ into the atmosphere (Aunela-Tapola et al. 1998). In the TGM data of the Finnish EMEP station at Virolahti, we noticed that when elevated TGM concentrations are observed, the typical source area according to the NOAA HYSPLIT back-trajectories seems to be in northern Estonia (data not published). It remains unclear whether the high TGM values at Isosaari in August resulted from a pollution plume from local sources or from further afield, possibly Estonia.

In May, concentrations above $100 \mathrm{ng} \mathrm{m}^{-3}$ were detected during a two-day period. At first, they were thought to be due to an instrumental failure, since such concentrations are not likely to be measured at background stations (Munthe et al. 2003, Kim et al. 2005). Closer inspection of the activities at the site showed that, unbeknown to us, target practice took place next to the station at exactly the same time as the elevated concentrations were measured. This led to the conclusion that mercury might originate from the shooting activities. In the firing practice, five $12.7 \mathrm{~mm}$ anti-aircraft machine guns were operated. We believe that the TGM originated from mercury fulminate in the rounds shot during the training. Mercury fulminate is a primary explosive and has been used widely in the past. Today, mercury fulminate has been replaced in primers by more efficient chemical substances such as lead compounds, but in military training old rounds are still used. On the first day, the 5-min concentrations had risen to 280 $\mathrm{ng} \mathrm{m}^{-3}$, and then returned to and remained at the background level of $1.4-1.9 \mathrm{ng} \mathrm{m}^{-3}$ during the night, and then skyrocketed again in the morning shortly after the firing resumed. The highest concentrations occurred during the second day, with values above $1000 \mathrm{ng} \mathrm{m}^{-3}$ for several hours, maximum value being $2470 \mathrm{ng} \mathrm{m}^{-3}$. After the second day of firing practice, the concentrations did not return to the background level until the sample line filter was replaced. We believe that the firing released huge amounts of particulate mercury in addition to TGM overloading the filter with particulate $\mathrm{Hg}$ (and possibly RGM trapped in the filter), which slowly 
transformed from the particulate form into the gaseous state. Wallace (1998) showed that when mercury-containing ammunition is used, $86 \%$ of the mercury is released mainly via the muzzle, of which $17 \%-20 \%$ was particulate, which supports our conclusion. Although Wallace (1998) reported that only a small percentage of mercury was deposited on the gun operator, our results indicate a possible health concern for the conscripts and especially for the military staff who regularly attend firing practices. For example, in the study by Munthe et al. (2003) similar to ours $\mathrm{Hg}$ concentrations $\left(1.4-26.9 \mu \mathrm{g} \mathrm{m}^{-3}\right)$ were measured in flue gas from five coal-fired (three hard coal and two brown coal) power plants. In a study by Frey and Hillamo (2011), TGM concentrations were measured in the raw flue gas of a coal-fired power plant in Helsinki and they were lower than those we measured during the firing practice maxima.

The average TGM concentrations remained stable throughout the year (Table 1), and their variability was small. In summer, when the consumption of energy is reduced resulting in less $\mathrm{Hg}$ emissions, a slightly smaller average concentration was recorded. The data collected during the firing practice were omitted from the spring average value, since the huge concentrations affected the average clearly (see Table 1).

The diurnal variation of TGM was calculated as monthly means for each hour, and proved to be very small. During the cold season (OctMar), there is practically no diurnal variation while in the warm season (Apr-Aug) slight differences were seen. At midnight and during the early morning hours, the concentrations were typically $\sim 0.2 \mathrm{ng} \mathrm{m}^{-3}$ higher than in the afternoon. This tendency is the opposite to that found at a forested background site in Finland (Kyllönen et al. 2012). In Helsinki, the concentration pattern in the warm season was opposite to that of air temperature and wind speed. In the cold season, the temperature and wind speed patterns were not as evident. On calm summer nights, mercury emitted from the sea and the soil around the station accumulates in the stable surface air and is then mixed in the morning as the wind speed increases and solar radiation breaks the surface inversion. In the cold season, the ice and snow covers inhibit this effect. Additionally, thermal mixing increases the boundary layer depth during the daytime and consequently dilutes TGM concentrations (Lee et al. 1998). Similar behaviour was observed e.g. in a rural region in England (Lee et al. 1998) and at urban sites in China (Feng et al. 2004), Sweden (Li et al. 2008) and the USA (Stamenkovich et al. 2007).

A clear majority (97\%) of the hourly TGM concentrations were in the range of $1-2 \mathrm{ng} \mathrm{m}^{-3}$, while $3 \%$ of the data were between 2 and 3 ng $\mathrm{m}^{-3}$ (Fig. 3). Hourly concentrations greater than $3 \mathrm{ng} \mathrm{m}^{-3}$ were rare, and if the firing practice data were omitted, they were almost nonexistent.

The TGM data were divided into wind sectors (Fig. 4) with the exception of the data collected during the firing practice. The lowest concentrations were found, quite unexpectedly, when the wind blew from the east, i.e., from Russia. Several pollutants, e.g., $\mathrm{SO}_{2}, \mathrm{NO}_{\mathrm{x}}$ and PAHs, typically arrive from this direction, St. Petersburg being one of the source areas (Vestenius et al. 2011). However, according to ESPREME (http:// espreme.ier.uni-stuttgart.de), the St. Petersburg area is a significant source for mercury emissions. As stated earlier in this chapter, a pollution

Table 1. Seasonal variation of TGM concentrations (mean \pm SD) and meteorological data measured in Helsinki from Oct 2006 to Aug 2007. Autumn = Oct-Nov, winter = Dec-Feb, spring = Mar-May, summer = Jun-Aug.

\begin{tabular}{lcccc}
\hline & Autumn & Winter & Spring & Summer \\
\hline TGM $\left(\mathrm{ng} \mathrm{m}^{-3}\right)$ & $1.57 \pm 0.17$ & $1.59 \pm 0.12$ & $1.59 \pm 0.21(6.1 \pm 81.6)^{\mathrm{a}}$ & $1.45 \pm 0.29$ \\
Temperature $\left({ }^{\circ} \mathrm{C}\right)$ & $5.9 \pm 4.3$ & $-0.7 \pm 6.5$ & $4.9 \pm 3.8$ & $16.3 \pm 2.7$ \\
Humidity $(\%)$ & $87 \pm 9$ & $85 \pm 8$ & $79 \pm 15$ & $79 \pm 12$ \\
Wind speed $\left(\mathrm{m} \mathrm{s}^{-1}\right)$ & $7.8 \pm 3.6$ & $8.1 \pm 3.4$ & $6.1 \pm 2.9$ & $5.5 \pm 2.8$ \\
Precipitation amount $(\mathrm{mm})$ & 216 & 149 & 84 & 172 \\
\hline
\end{tabular}

${ }^{a}$ Firing practice data included. 


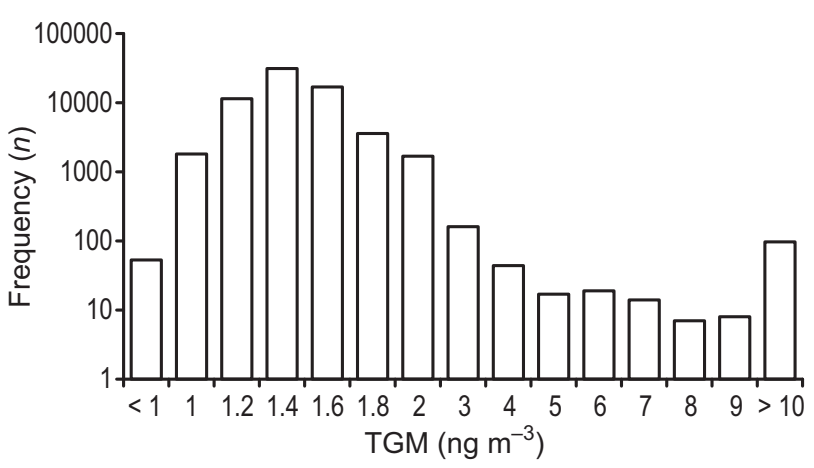

Fig. 3. Frequency pattern of 5-min TGM concentrations in Helsinki during the study period. Concentrations of $1-2 \mathrm{ng} \mathrm{m}^{-3}$ are at $0.2 \mathrm{ng} \mathrm{m}^{-3}$ intervals (e.g. a bar of 1.2 represents data in the range of $1.20-1.39 \mathrm{ng} \mathrm{m}^{-3}$ ) while higher concentrations are at $1 \mathrm{ng} \mathrm{m}^{-3}$ intervals.

plume with concentrations above $10 \mathrm{ng} \mathrm{m}^{-3}$ was recorded during prevailing easterly winds. One should note that only $6.9 \%$ of the wind factors at the site are related to this low-concentration factor $\left(90^{\circ}-130^{\circ}\right)$, while typical wind factors are from the west and southwest $\left(45 \%, 210^{\circ}-290^{\circ}\right)$. Still, both the median and the 5 and 95 percentiles remained mostly low for the ESE sector.

The highest concentrations occurred with winds in the $300^{\circ}-40^{\circ}$ sectors ( $\mathrm{N}$ factor) and the $160^{\circ}-240^{\circ}$ sector ( $\mathrm{S}$ factor). The $\mathrm{N}$ factor is accounted for by domestic and especially, by close emission sources. Two coal-fired power plants and a natural gas power station are located in Helsinki, and these produce annually approximately $1000 \mathrm{MW}$ of electricity and $1500 \mathrm{MW}$ of municipal heating. The S factor contains polluted air masses from the highly-industrialised Baltic and European areas.
To study the source areas for high TGM concentrations in more detail, a TGM concentration field for Isosaari was calculated (Fig. 5). According to the trajectory analysis, the strongest source areas for Helsinki were located in the densely-populated and industrialized areas of central Europe, and also to some extent in the southern part of eastern Europe. Additionally, there seemed to be a source area in Russia. However, these Russian grid points with high concentration values were located on the periphery of the map and the exact location was thus uncertain. This source might explain the high 95th percentile for the $80^{\circ}$ wind sector (Fig. 4). Low concentrations over the sea and Fenno-Scandinavia resulted from the lack of significant sources in these areas. The TGM concentration field (Fig. 5) resembled the spatial distribution map of mercury emissions over the EMEP domain in 2010 as modelled by EMEP (Travnikov et al. 2012), thus indicating that the hot spot sources detected by trajectory analysis are in line with the anthropogenic emissions.

Since mercury as an airborne pollutant has a rather long lifetime of 0.5-2 years (Schroeder and Munthe 1998), the Hg emissions from neighbouring countries affect the ambient air concentration levels in Helsinki in addition to domestic $\mathrm{Hg}$ emissions. According to ESPREME (http:// espreme.ier.uni-stuttgart.de), the total annual emissions in 2000 of $\mathrm{Hg}$ in Finland, Estonia, Latvia, Lithuania, Poland and Russia were 0.60, $0.55,0.15,0.25,25.6$ and $66.1 \mathrm{t}$, respectively.

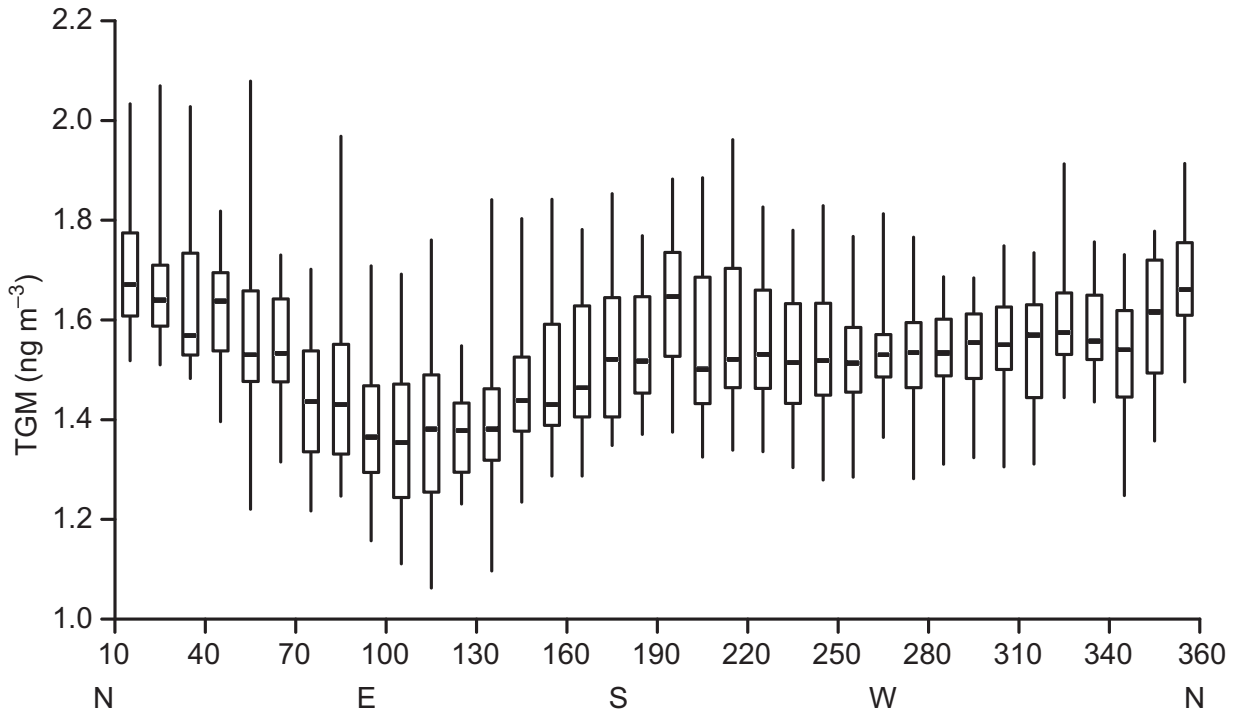

Fig. 4. TGM distribution in different wind sectors. The box represents the 25th and 75 th percentiles, the line gives the median concentrations, and whiskers the 5th and 95th percentiles. 
Fig. 5. TGM concentration field for Helsinki calculated from the hourly TGM concentrations.

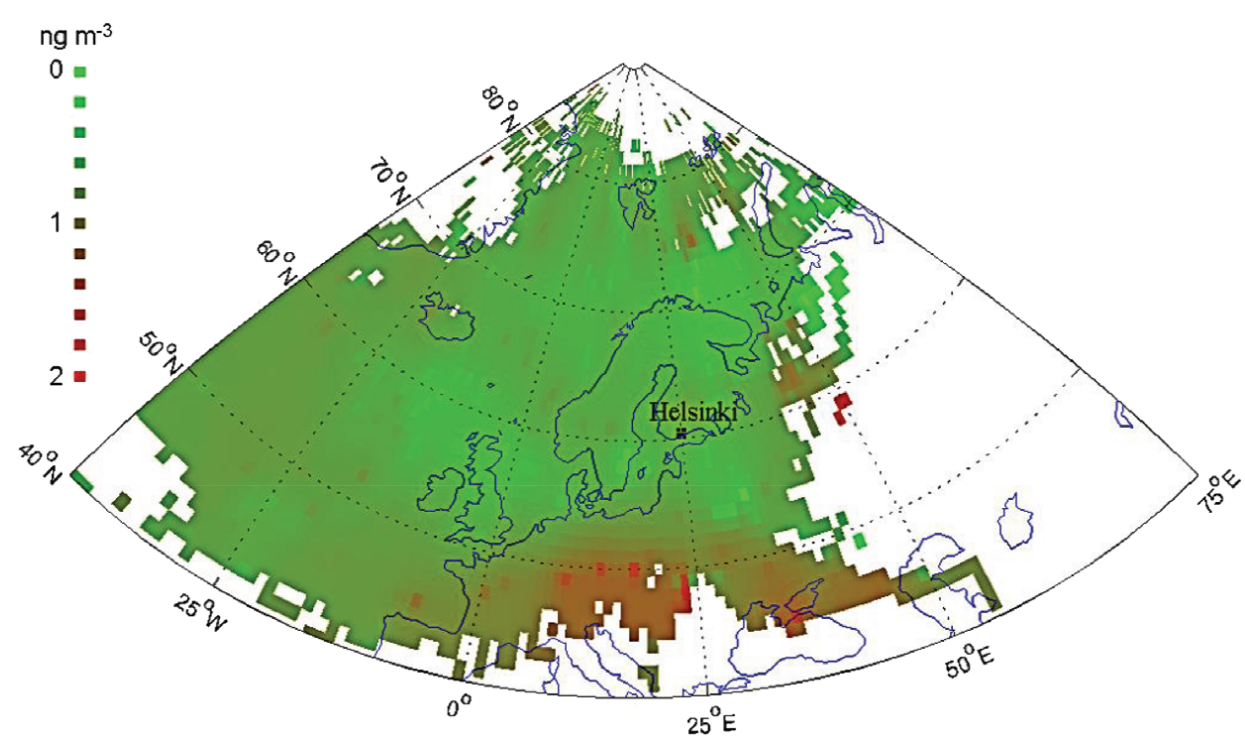

\section{Nationwide survey}

In the mobile measurement campaign, all the major population centres and a large number of industrial sites were surveyed by online measurements from a moving car. Furthermore, most of the municipalities in the country were visited with the exception of the province of Lapland. The industrial sites visited included e.g. former chlor-alkali plants, power plants, chemical industry and pulp and paper mills.

The measurement days were mostly sunny or cloudy, while rain occurred a few times. During rain showers measurements were stopped to prevent water from entering the instrument through the horizontally-placed sampling tube on the roof of the car. In fog, measurements were conducted, but concentrations were typically lower than just before or after it. We believe that this phenomenon is caused by gaseous mercury binding to the tiny water droplets, as clouds act as a reaction vessel for aqueous chemistry, influencing the rates at which atmospheric $\mathrm{Hg}$ is incorporated into raindrops (Malcolm et al. 2003) and $\mathrm{Hg}$ is accumulated and concentrated in fog banks (Ritchie et al. 2006).

The majority of the measured concentrations remained at a low level, with no clear local influence (Fig. 6A). During the campaign, $89 \%$ of the data were below the global average of 1.7 $\mathrm{ng} \mathrm{\textrm {m } ^ { - 3 }}$ with a median of $1.56 \pm 0.91 \mathrm{ng} \mathrm{m}^{-3}$ for the whole data set. The 5th and 95th percentiles of the whole data were 1.13 and $1.97 \mathrm{ng} \mathrm{m}^{-3}$, respectively, indicating a quite stable TGM concentration throughout Finland. This is due to the stable behaviour of this element and lack of significant local sources. It was noted that during different measurement days, the concentration levels changed a bit as can be seen in the bluish and greenish routes on the map (see Fig. 6A). This occurrence was also evident in the data from the measurements at the same location on different days. Due to changing wind patterns, the effect of long-range transported pollution plumes varied. The changes were small though, indicating an effective mixing of this long-life pollutant. Also changing weather (i.e. fog) affected the concentration level, as noted earlier. One must also remember that the instrument has a measurement uncertainty of $10 \%$, so that changes of about $0.1 \mathrm{ng} \mathrm{m}^{-3}$ can also be due to instrumental performance.

Only $2 \%$ of the data exceeded $3 \mathrm{ng} \mathrm{m}^{-3}$. These events were short and never represented the concentration level in an entire town. These peaks were measured close to an obvious source and remained high only in certain measurement places. Typically, a few hundred metres away from the location of the high TGM concentration, it declined back to the background level. This measurement method may have neglected some hot-spot areas due to unfavorable wind conditions or difficulties in driving to the optimal measurement location.

High TGM concentrations (here $>3 \mathrm{ng} \mathrm{m}^{-3}$ ) were measured in certain areas of Riihimäki, 
A

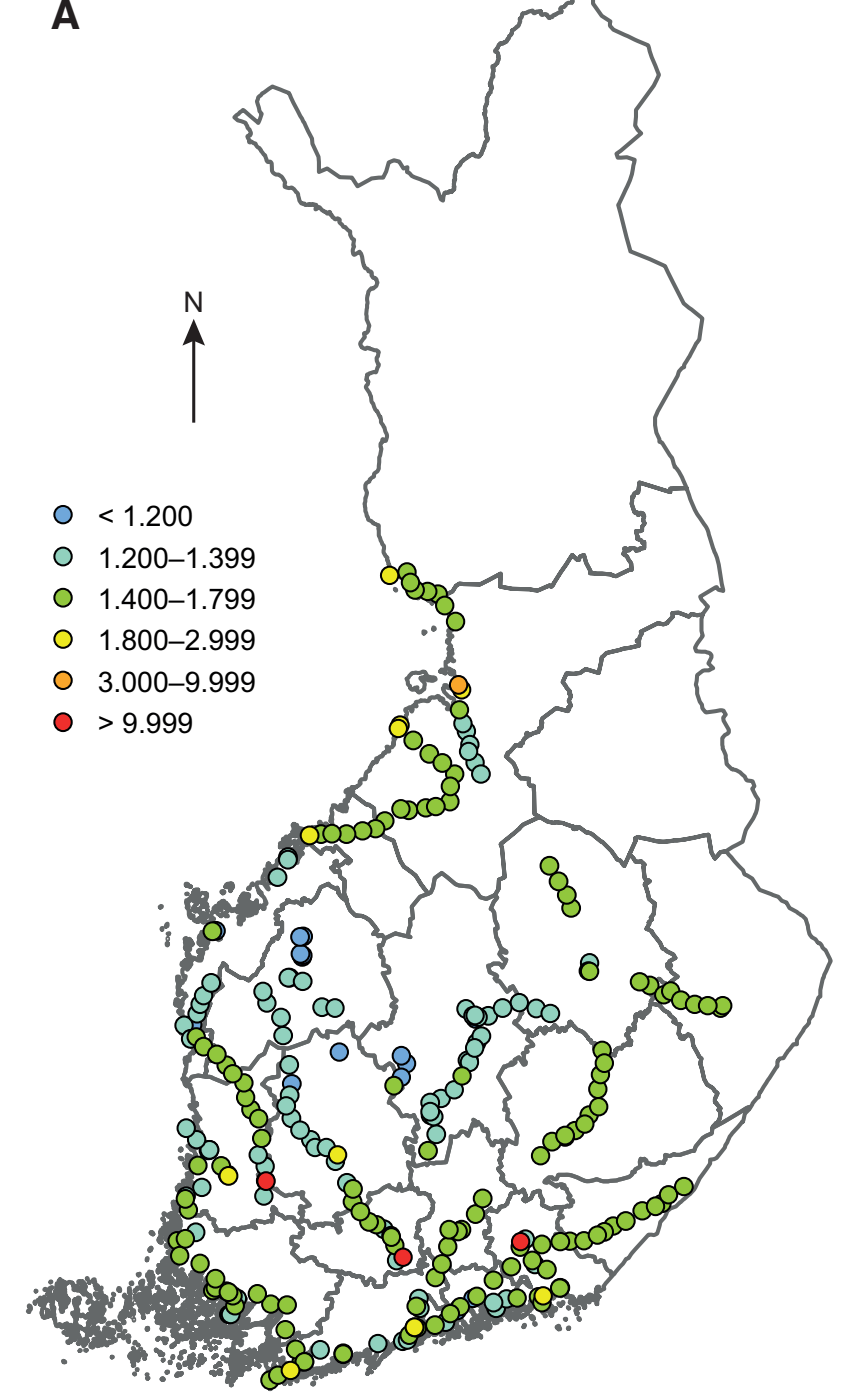

B

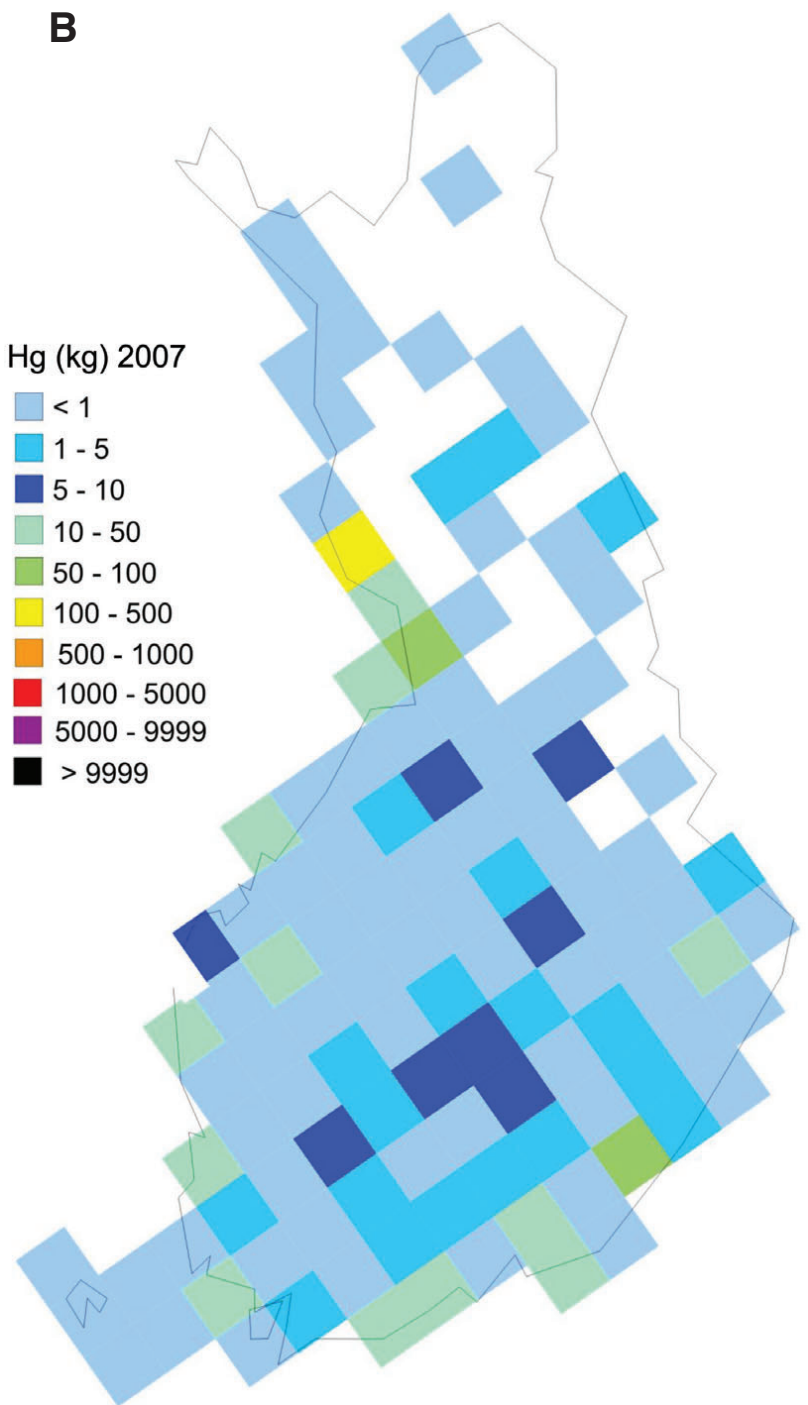

Fig. 6. (A) TGM concentrations (ng $\mathrm{m}^{-3}$ ) measured during the mobile measurement campaign in Finland. Red dots are at Äetsä, Riihimäki and Kuusankoski (left to right) and the orange dot is at Oulu. (B) Spatial distribution of mercury emissions in Finland in 2007 (source Finnish Environment Institute 2013b; reproduced with permission from the copyright holder).

Äetsä, Kuusankoski and Oulu. With the exception of Riihimäki, the common factor for all these sites was proximity to a chemical industrial plant. In Riihimäki, concentrations in the range of $1.5-10.5 \mathrm{ng} \mathrm{m}^{-3}$ were measured in the vicinity of a toxic-waste disposal plant. We believe that the peak concentrations here may have resulted from toxic waste located temporarily in the outdoor area, since elevated levels were measured next to the building only and not in the area around it.

In Äetsä, concentrations reaching $14 \mathrm{ng} \mathrm{m}^{-3}$ were measured in a residential area next to the chemical plant and a former chlor-alkali plant. It remains undetermined whether the high concentrations were due to mercury emissions from the current chemical industrial processes, or a result of past chlor-alkali activities at the same site causing (a) strong re-emission of $\mathrm{Hg}$ from polluted ground in the area or (b) possible residual mercury in the stacks currently used for other industrial processes. In Kuusankoski, a maximum of $13.0 \mathrm{ng} \mathrm{m}^{-3}$ was similarly detected next to a chemical industrial plant and a former chloralkali plant. However, at this location the concentration levels varied widely in the vicinity of the plant. The environmental impact of these two former chlor-alkali plants has been noted earlier (Sarvala and Sarvala 2008, Verta et al. 2009). In the coastal surface and river sediments close to both locations, elevated levels of mercury were detected, and these results were considered to be from former chlor-alkali plants (Sarvala and Sarvala 2008, Verta et al. 2009) and in the case of 
Kuusankoski also from the pulp and paper industry (Verta et al. 2009). Despite these findings, in the vicinity of another former chlor-alkali plant in Joutseno no elevated TGM levels were measured as compared with the background concentration of $1.5 \mathrm{ng} \mathrm{m}^{-3}$ in the area.

The only chlor-alkali plant remaining in Finland is located in an industrial area of Oulu. The area was not accessible by car; concentrations up to $4.6 \mathrm{ng} \mathrm{m}^{-3}$ were measured outside the industrial area. Much higher concentrations (around 50-250 $\mathrm{ng} \mathrm{m}^{-3}$ ) were measured in 2001 in the plumes of a chlor-alkali plant in Sweden, $70 \mathrm{~m}$ from the source (Wängberg et al. 2003). However, in a residential area $560 \mathrm{~m}$ away from the plant, concentrations of 1.4-40 $\mathrm{ng} \mathrm{m}^{-3}$ were detected $\left(\right.$ mean $\left.=3.5 \mathrm{ng} \mathrm{m}^{-3}\right)$ (Wängberg et al. 2005).

Elevated levels were also measured in Helsinki, Tampere, Harjavalta, Kokkola, Raahe and Tornio (up to 2.8, 2.0, 2.3, 2.2, 2.1 and 2.7 $\mathrm{ng} \mathrm{m}^{-3}$, respectively). These were all detected within industrial areas, or in one case in a residential area. In Helsinki, the areas around crematoria were carefully surveyed, but no increase in TGM concentrations were found during the campaign.

The Finnish Environment Institute maintains a national environmental monitoring database VAHTI containing the reports made periodically by individual facilities regarding their pollutant (e.g. $\mathrm{Hg}$ ) emissions. The top five polluters include the steel and chemical industry, while most of the facilities reporting $\mathrm{Hg}$ emissions are power plants (data not shown). Globally, coal combustion is the main source of $\mathrm{Hg}$ emissions (Pirrone et al. 2010). We could not clearly connect power production with elevated concentration levels during our mobile measurement campaign. This is likely to be due to effective dilution resulting from the use of tall smokestacks in power plants.

\section{Comparison with other studies}

There are no published urban or industrial TGM data in Finland with which to compare our measurements. In June 1971, particle-bound mercury with an average concentration of $0.28 \mathrm{ng} \mathrm{m}^{-3}$ and maximum of $1.0 \mathrm{ng} \mathrm{m}^{-3}$ was measured in central Helsinki by the Department of Radiochemistry, University of Helsinki (Miettinen 1973, as cited in Mattsson and Jaakkola 1979). As mercury exists mostly in the gaseous elemental form $\mathrm{Hg}^{0}$ (95\%-99\%), while mercury associated with particulate matter makes up only $0.2 \%-1.4 \%$ (Ebinghaus et al. 2008), we used a very rough estimating factor of 100 to calculate the TGM concentration in Helsinki in 1971. This would give an approx. mean value of $30 \mathrm{ng} \mathrm{m}^{-3}$ of TGM and a maximum of $100 \mathrm{ng} \mathrm{m}^{-3}$ of TGM in Helsinki during that year. These figures are about 20 times higher than the average TGM concentration and seven times higher than the maximum TGM concentration measured in Helsinki during our study. These high concentrations were due to the incineration of unsorted household waste and heating of buildings with coal (Mattsson and Jaakkola 1979). However, these values are uncertain, since the ratio between TGM and particle-bound mercury may then have been smaller, and the measurement method did not take into account the problem of mercury interactions with the particles collected on the filter.

Additionally, we made a comparison with recent TGM data from other countries (Table 2) to set the mercury situation in Helsinki into a global perspective. In Asia and Mexico, much higher TGM concentrations are found in urban areas as compared with the sites in Europe and North America. Our results from the one-year study in Helsinki and the mobile measurement campaign around the country, are located in the lower part of those given in the published studies (see Table 2).

\section{Mercury emissions in Finland}

According to the national mercury emissions reported by the Finnish Environment Institute (SYKE), during the last two decades Hg emissions did not change much. After 1990, the annual emission levels of $\mathrm{Hg}$ into the air have been below $1000 \mathrm{~kg}$ (Fig. 7, numerical values obtained from the Finnish Environment Institute 2013a). In recent years, emissions have remained rather steady, although unfortunately at the same level as in the early 1990s. The time series is not 


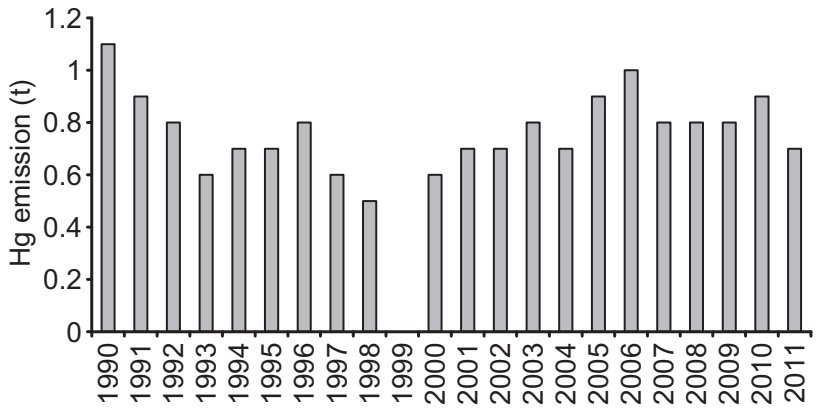

Fig. 7. Mercury emissions into the air in Finland in 1990-2011.

fully consistent due to the pending recalculation of the energy-sector emissions. According to the European Environment Agency (EEA), a clear decreasing trend in $\mathrm{Hg}$ emissions occurred in Europe in 1990-2010 (European Environment Agency 2014a). Additionally, EEA reports a 20\% decrease in the $\mathrm{Hg}$ emissions in Finland during the same period (European Environment Agency 2014b). However, even so, this reduction is among the smallest in the EEA Member Countries. In the other Nordic countries, the reduction was substantial $(60 \%-85 \%)$.

A map of $\mathrm{Hg}$ emissions in 2007 (Fig. 6B) published in Finnish Environment Institute (2013b) shows some resemblance to our map (Fig. 6A), although in certain emission areas we did not detect any increase in TGM concentrations. This is likely due to the limitations of our measurement method, addressed earlier in this article.

Table 2. Summary of TGM (or gaseous elemental mercury, GEM) measurements in urban areas and close to point sources.

\begin{tabular}{|c|c|c|c|c|c|}
\hline Location & Site & Year & Period & $\begin{array}{l}\text { Mean } \pm \text { SD }(\min -\max ) \\
\text { TGM or GEM }\left(\mathrm{ng} \mathrm{m}^{-3}\right)\end{array}$ & Reference \\
\hline \multirow{3}{*}{$\begin{array}{l}\text { Helsinki, Finland } \\
\text { Finland* }^{*}\end{array}$} & \multirow{3}{*}{$\begin{array}{l}\text { Urban } \\
\text { Industrial, urban, } \\
\text { background }\end{array}$} & 2006-2007 & 11 months & $1.54 \pm 0.20(0.86-14.9)$ & Our study, \\
\hline & & & & & part 1 \\
\hline & & 2007 & 1 month & $(0.97-13.75)$ & $\begin{array}{l}\text { Our study, } \\
\text { part } 2\end{array}$ \\
\hline Taiwan & Industrial/urban & 2010 & 7 months & $6.66 \pm 1.42$ & Jen et al. (2013) \\
\hline Nanjing, China & Urban & 2011 & $1 \mathrm{yr}$ & $7.9 \pm 7.0(0.8-180)$ & Zhu et al. (2012) \\
\hline Taiwan & Urban & 2010-2011 & $1 \mathrm{yr}$ & $6.14 \pm 3.91$ & $\begin{array}{l}\text { Huang et al. } \\
(2012)\end{array}$ \\
\hline Detroit, USA & Urban/Industrial & 2004 & $1 \mathrm{yr}$ & $2.5 \pm 1.4(0.36-25.6)$ & Liu et al. (2010) \\
\hline Reno, USA & Urban & 2004-2007 & $3 \mathrm{yr}$ & $1.6 \pm 0.5(0.5-6.4)$ & $\begin{array}{l}\text { Peterson et al. } \\
(2009)\end{array}$ \\
\hline Seoul, Korea & Urban & 2005-2006 & $1 \mathrm{yr}$ & $3.22 \pm 2.10$ & Kim et al. (2009) \\
\hline Mexico City & Urban & 2006 & 1 month & $7.2 \pm 4.8$ & $\begin{array}{l}\text { Rutter et al. } \\
(2009)\end{array}$ \\
\hline Gothenburg, Sweden & Urban & 2005 & 1 month & $1.96 \pm 0.38$ & Li et al. (2008) \\
\hline Belgium & Industrial & 1999-2004 & - & $20(\max 150)$ & $\begin{array}{l}\text { De Temmerman } \\
\text { et al. (2007) }\end{array}$ \\
\hline Reno, USA & Urban & 2002-2005 & $3 \mathrm{yr}$ & $2.3 \pm 0.6(0.9-8.6)$ & $\begin{array}{l}\text { Stamenkovic } \\
\text { et al. (2007) }\end{array}$ \\
\hline Quebec, Canada & Urban & 2003 & $1 \mathrm{yr}$ & $1.65 \pm 0.42$ & $\begin{array}{l}\text { Poissant } \\
\text { et al. (2005) }\end{array}$ \\
\hline Bohus, Sweden & Industrial & $2001-2003$ & 10 weeks & $55(1.5-540)$ & $\begin{array}{l}\text { Wängberg } \\
\text { et al. (2005) }\end{array}$ \\
\hline Bohus, Sweden & Industrial/urban & 2001-2003 & 10 weeks & $3.5(1.4-40)$ & $\begin{array}{l}\text { Wängberg } \\
\text { et al. (2005) }\end{array}$ \\
\hline Michigan, USA & Industrial (2) & 2000 & 10 days & 3.9 and $8.7(1.9-77.6)$ & $\begin{array}{l}\text { Landis et al. } \\
(2004)\end{array}$ \\
\hline Grenoble, France & Industrial/suburban & 1999-2000 & 40 days & $3.4 \pm 3.6(\max 45.9)$ & $\begin{array}{l}\text { Dommergue } \\
\text { et al. (2002) }\end{array}$ \\
\hline
\end{tabular}

* Comprises several measuring locations around the country. 


\section{Conclusions}

This study presents the total gaseous mercury (TGM) concentrations in the air in Finland measured during (1) a one-year measurement campaign at an urban background station in Helsinki, Finland, to measure TGM concentrations in the air and to study the behaviour of this pollutant; and (2) a mobile measurement campaign around Finland to study the regional variation of TGM in urban, industrial and background areas and to find possible $\mathrm{Hg}$ hot spots.

The hourly TGM values measured during the one-year urban campaign mostly remained close to the global background value, with an average of $1.54 \pm 0.20 \mathrm{ng} \mathrm{m}^{-3}$. Proximity to both local pollution sources (city of Helsinki) and neighbouring countries with high mercury emissions was reflected in the frequent peaks in the data. The seasonal variation of TGM concentrations was small, however slightly smaller than average concentrations were measured in summer due to less energy consumption. A diurnal variation was observed during the warm season (Apr-Aug) with a peak at night or during early morning hours. Values above $1000 \mathrm{ng} \mathrm{m}^{-3}$ were detected for several hours on one measurement day when, a firing practice took place next to the station.

During the mobile measurement campaign, the highest concentrations $\left(10-15 \mathrm{ng} \mathrm{m}^{-3}\right)$ were measured in the immediate vicinity of certain chemical manufacturing plants formerly used in chlor-alkali industry, and a toxic waste disposal plant. In other industrial areas or residential areas close to industry, the TGM concentrations were less than $5 \mathrm{ng} \mathrm{m}^{-3}$. In general, the measured concentrations were low, with a median of 1.43 $\mathrm{ng} \mathrm{m}^{-3}$, and elevated levels of TGM could not be connected to power plant emissions or crematoria.

The results from these campaigns indicate that the domestic anthropogenic emissions are only a minor source of mercury exposure to the general public in Finland.

Acknowledgements: This project was partially funded by the Ministry of the Environment. The authors are grateful for the support by The Finnish Defence Forces officers and conscripts at the Isosaari military base. Map production assistance by Mr. Pentti Pirinen, FMI, is gratefully acknowledged. Additionally we thank Ms. Kristina Saarinen, SYKE, for help with interpretation of emission data.

\section{References}

AMAP 2011. AMAP assessment 2011: Mercury in the Arctic. Arctic Monitoring and Assessment Programme (AMAP), Oslo, Norway.

Aunela-Tapola L.A., Frandsen F.J. \& Häsänen E.K. 1998. Trace metal emissions from the Estonian oil shale fired power plant. Fuel Processing Technology 57: 1-24.

De Temmerman L., Claeys N., Roekens E. \& Guns M. 2007. Biomonitoring of airborne mercury with perennial ryegrass cultures. Environ. Poll. 146: 458-462.

Dommergue A., Ferrari C.P., Planchon F.M.A. \& Boutron C.F. 2002. Influence of anthropogenic sources on total gaseous mercury variability in Grenoble suburban air (France). Sci. Total Environ. 297: 203-213.

Ebinghaus R., Jennings S.G., Schroeder W.H., Berg T., Donaghy T., Guentzel J., Kenny C., Kock H.H., Kvietkus K., Landing W., Mühleck T., Munthe J., Prestbo E.M., Schneeberger D., Slemr F., Sommar J., Urba A., Wallschläger D. \& Xiao Z. 1999. International field intercomparison measurements of atmospheric mercury species at Mace Head, Ireland. Atmos. Environ. 33: 3063-3073.

Ebinghaus R., Banic C., Beauchamp S., Jaffe D., Kock H.H., Pirrone N., Poissant L., Sprovieri F. \& Weiss P.S. 2008. Spatial coverage and temporal trends of land-based atmospheric mercury measurements in the northern and southern hemispheres. In: Pirrone N. \& Mason R. (eds.), Mercury fate and transport in the global atmosphere: measurements, models and policy implications, Springer Science + Business Media, New York, pp. 168-219.

European Environment Agency 2014a. Change in cadmium, mercury and lead emissions for each sector between 1990 and 2010 (EEA member countries). Available at http://www.eea.europa.eu/data-and-maps/daviz/changein-cadmium-mercury-and\#tab-chart_1.

European Environment Agency 2014b. The reported change in mercury ( $\mathrm{Hg}$ ) emissions for each country, 1990-2010. Available at http://www.eea.europa.eu/data-and-maps/ figures/change-in-mercury-emissions-1990-2007-eeamember-countries-3.

European Parliament, Council 2004. Directive 2004/107/ EC of the European Parliament and of the Council of 15 December 2004 relating to arsenic, cadmium, mercury, nickel and polycyclic aromatic hydrocarbons in ambient air. Official Journal of the European Union L23: 3-16.

Feng X., Shang L., Wang S., Tang S. \& Zheng W. 2004. Temporal variation of total gaseous mercury in the air of Guiyang, China. J. Geophys. Res. 109, D03303, doi:10.1029/2003JD004159.

Finnish Environmental Institute 2013a. Air pollutant emissions in Finland. Available at http://www.ymparisto. fi/en-US/Maps_and_statistics/Air_pollutant_emissions.

Finnish Environmental Institute 2013b. Spatial distribution of air pollutant emissions in Finland. Available at http:// www.ymparisto.fi/en-us/Maps_and_statistics/Air_pollutant_emissions/Spatial_distribution_of_air_pollutant_ emissions.

Frey A. \& Hillamo R. 2011. Fine particle emissions of a heavy fuel oil-fired heating station and a coal-fired power plant: Helsinki Energy Research report. Internal 
report 11/2011, Helsinki Energy.

Helsingin Energia 2010. Power plants. Available at http:// www.helen.fi/en/Households/Information/Energy-andthe-environment/Energy-production/Power-plants/.

Huang J., Liu C.K., Huang C.S. \& Fang G.C. 2012. Atmospheric mercury pollution at an urban site in central Taiwan: Mercury emission sources at ground level. Chemosphere 87: 579-585.

Jen Y.H., Yuan C.S., Hung C.H., Ie I.R. \& Tsai C.M. 2013. Tempospatial variation and partition of atmospheric mercury during wet and dry seasons at sensitivity sites within a heavily polluted industrial city. Aerosol Air Qual. Res. 13: 13-23.

Kim K.H., Ebinghaus R., Schroeder W.H., Blanchard P., Kock H.H., Steffen A., Froude F.A., Kim M.Y., Hong S. \& Kim J.H. 2005. Atmospheric mercury concentrations from several observatory sites in the northern hemisphere. J. Atmos. Chem. 50: 1-24.

Kim S.H., Han Y.J., Holsen T.M. \& Yi S.M. 2009. Characteristics of atmospheric speciated mercury concentrations (TGM, $\mathrm{Hg}(\mathrm{II})$ and $\mathrm{Hg}(\mathrm{p})$ ) in Seoul, Korea. Atmos. Environ. 43: 3267-3274.

Kyllönen K., Hakola H., Hellén H., Korhonen M. \& Verta M. 2012. Atmospheric mercury fluxes in southern boreal forest and wetland. Water Air Soil Pollut. 223: 1171-1182.

Landis M.S., Keeler G.J., Al-Walib K.I. \& Stevens R.K 2004. Divalent inorganic reactive gaseous mercury emissions from a mercury cell chlor-alkali plant and its impact on near-field atmospheric dry deposition. Atmos. Environ. 38: 613-622.

Li J., Sommar J., Wängberg I., Lindqvist O. \& Wei S. 2008. Short-time variation of mercury speciation in the urban of Göteborg during GÖTE-2005. Atmos. Environ. 42: $8382-8388$

Liu B., Keeler G.J., Dvonch J.T., Barres J.A., Lynam M.M., Marsik F.J. \& Morgan J.T. 2010. Urban-rural differences in atmospheric mercury speciation. Atmos. Environ. 44: 2013-2023.

Malcolm, E.G., Keeler G.J., Lawson S.T. \& Sherbatskoy T.D. 2003. Mercury and trace elements in cloud water and precipitation collected on Mt. Mansfield, Vermont. J. Environ. Monit. 5: 584-590.

Mattsson R. \& Jaakkola T. 1979. An analysis of Helsinki air 1962 to 1977 based on trace metals and radionuclides. Geophysica 16: 1-42

Munthe J., Wängberg I., Iverfeldt Å., Lindqvist O., Strömberg D., Sommar J., Gårdfeldt K., Petersen G., Ebinghaus R., Prestbo E., Larjava K. \& Siemens V. 2003. Distribution of atmospheric mercury species in Northern Europe: final results from the MOE project Atmos. Environ. 37, Suppl. 1: S9-S20.

Pacyna E.G., Pacyna J.M., Steenhuisen F. \& Simon Wilson S. 2006a. Global anthropogenic mercury emission inventory for 2000. Atmos. Environ. 40: 4048-4063.

Pacyna E.G., Pacyna J.M., Fudala J., Strzelecka-Jastrzab E., Hlawiczka S. \& Panasiuk D. 2006b. Mercury emissions to the atmosphere from anthropogenic sources in Europe in 2000 and their scenarios until 2020. Sci. Total Environ. 370: 147-156.

Pirjola L., Parviainen H., Hussein T., Valli A., Hämeri K.,
Aalto P., Virtanen A., Keskinen J., Pakkanen T.A., Mäkelä T. \& Hillamo R.E. 2004. "Sniffer" - a novel tool for chasing vehicles and measuring traffic pollutants. Atmos. Environ. 38: 3625-3635.

Pirjola L., Kupiainen K.J., Perhoniemi P., Tervahattu H. \& Vesala H. 2009. Non-exhaust emission measurement system of the mobile laboratory SNIFFER. Atmos. Environ. 43: 4703-4713.

Pirjola L., Lahde T., Niemi J.V., Kousa A., Ronkko T., Karjalainen P., Keskinen J., Frey A. \& Hillamo R. 2012. Spatial and temporal characterization of traffic emissions in urban microenvironments with a mobile laboratory. Atmos. Environ. 63: 156-167.

Pirrone N., Cinnirella S., Feng X., Finkelman R. B., Friedli H. R., Leaner J., Mason R., Mukherjee A.B., Stracher G.B., Streets D.G. \& Telmer K. 2010. Global mercury emissions to the atmosphere from anthropogenic and natural sources. Atmos. Chem. Phys. Discuss. 10: 4719-4752.

Poissant L., Pilote M., Beauvais C., Constant P. \& Zhang H.H. 2005. A year of continuous measurements of three atmospheric mercury species (GEM, RGM and Hgp) in southern Québec, Canada. Atmos. Environ. 39: 1275-1287.

Ritchie C.D., Richards W. \& Arp P.A. 2006. Mercury in fog on the Bay of Fundy (Canada). Atmos. Environ. 40: 6321-6328.

Rutter A.P., Snyder D.C., Stone E.A., Schauer J.J., GonzalezAbraham R., Molina L.T., Márquez C., Cárdenas B. \& de Foy B. 2009. In situ measurements of speciated atmospheric mercury and the identification of source regions in the Mexico City Metropolitan Area. Atmos. Chem. Phys. 9: 207-220.

Sarvala M. \& Sarvala J. (eds.) 2005. Miten voit, Selkämeri? Ympäristön tila Lounais-Suomessa 4, Lounais-Suomen ympäristökeskus, Turku.

Schroeder W. \& Munthe J. 1998. Atmospheric mercury - an overview. Atmos. Environ. 32: 809-822.

Slemr F., Brunke E.-G., Ebinghaus R., Temme C., Munthe J., Wängberg I., Schroeder W., Steffen A. \& Berg T. 2003. Worldwide trend of atmospheric mercury since 1977. Geophys. Res. Lett. 30, 1516, doi:10.1029/2003GL016954.

Stamenkovic J., Lyman S. \& Gustin M.G. 2007. Seasonal and diel variation of atmospheric mercury concentrations in the Reno (Nevada, USA) airshed. Atmos. Environ. 41: 6662-6672.

Stohl A., Wotawa G., Seibert P. \& Kromp-Kolb H. 1995. Interpolation errors in wind fields as a function of spatial and temporal resolution and their impact on different types of kinematic trajectories. J. Appl. Meteorol. 34: 2149-2165.

Stohl A. 1996. Trajectory statistics - a new method to establish source-receptor relationships of air pollutants and its application to the transport of particulate sulfate in Europe. Atmos. Environ. 30: 579-587.

Stohl A. \& Seibert P. 1998. Accuracy of trajectories as determined from the conservation of meteorological tracers. Q.J.R. Meteor. Soc. 124: 1465-1484.

Travnikov O., Ilyin I., Rozovskaya O., Varygina M., Aas W., Uggerud H.T., Mareckova K. \& Wankmueller R. 2012. Long-term changes of heavy metal transboundary pol- 
lution of the environment (1990-2010). EMEP Status Report 2/2012.

Verta M., Kiviranta H., Salo, S., Malve O., Korhonen M., Verkasalo P.K., Ruokojärvi P., Rossi E., Hanski A., Päätalo K. \& Vartiainen T. 2009. A decision framework for possible remediation of contaminated sediments in the River Kymijoki, Finland. Environ Sci. Pollut. Res. Int. 16: 95-105.

Vestenius M., Leppänen S., Anttila P., Kyllönen K., Hatakka J., Hellén H., Hyvärinen A. \& Hakola H. 2011. Background concentrations and source apportionment of polycyclic aromatic hydrocarbons in south-eastern Finland. Atmos. Environ. 45: 3391-3399.

Wallace J.S. 1998. Discharge residue from mercury fulmi- nate-primed ammunition. Science \& Justice 38: 7-14

Wängberg I., Edner H., Ferrara R., Lanzillotta E., Munthe J., Sommar J., Sjöholm M., Svanberg S. \& Weibring P. 2003. Atmospheric mercury near a chlor-alkali plant in Sweden. Sci. Total Environ. 304: 29-41.

Wängberg I., Barregard L., Sällsten G., Haeger-Eugensson M., Munthe J. \& Sommar J. 2005. Emissions, dispersion and human exposure of mercury from a Swedish chloralkali plant. Atmos. Environ. 39: 7451-7458.

Zhu J., Wang T., Talbot R., Mao H., Hall C.B., Yang X., Fu C., Zhuang B., Li S., Han Y. \& Huang X. 2012. Characteristics of atmospheric Total Gaseous Mercury (TGM) observed in urban Nanjing, China. Atmos. Chem. Phys. 12: $12103-12118$. 



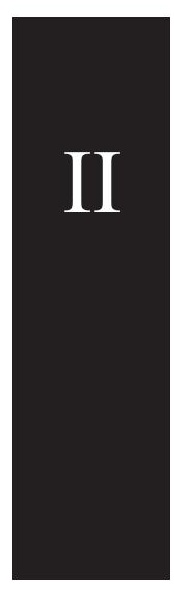





\title{
Atmospheric Mercury Fluxes in a Southern Boreal Forest and Wetland
}

\author{
Katriina Kyllönen • Hannele Hakola • \\ Heidi Hellén • Markku Korhonen • Matti Verta
}

Received: 18 April 2011 / Accepted: 11 August 2011 /Published online: 1 September 2011

(C) Springer Science+Business Media B.V. 2011

\begin{abstract}
Total gaseous mercury (TGM) fluxes from the forest floor and a boreal wetland were measured by a flux chamber technique coupled with an automatic mercury vapour analyser. The fluxes were measured at three sampling sites in southern Finland, $61^{\circ} 14^{\prime} \mathrm{N}, 25^{\circ} 04^{\prime} \mathrm{E}$ in summer 2007 , with additionally in situ TGM concentrations in the air at one of the sites and mercury bulk deposition at another. Most of the flux data were collected during the daytime. At one of the sites, diurnal flux behaviour was studied, and a clear cycle with an afternoon maximum and a night minimum was observed. The highest emissions (up to $3.5 \mathrm{ng} \mathrm{m}^{-2} \mathrm{~h}^{-1}$ ) were observed at the forest floor site having a moss and grass cover. At the wetland and litter-rich forest floor sites, the emissions were below $1 \mathrm{ng} \mathrm{m}^{-2} \mathrm{~h}^{-1}$ and sometimes negative (down to $-1.0 \mathrm{ng} \mathrm{m}^{-2} \mathrm{~h}^{-1}$ ), indicating mercury uptake. The measured average fluxes in August were $0.9 \pm 1.1$ and $0.2 \pm 0.3 \mathrm{ng} \mathrm{m}^{-2} \mathrm{~h}^{-1}$ for the forest floor sites and wetland sites, respectively. The flux data were compared with the mercury bulk deposition, which proved to be of the same magnitude, but
\end{abstract}

K. Kyllönen $\cdot$ H. Hakola $(\bowtie) \cdot H$. Hellén

Air Quality Department, Finnish Meteorological Institute,

P.O. Box 503, 00101 Helsinki, Finland

e-mail: hannele.hakola@fmi.fi

M. Korhonen $\cdot$ M. Verta

Research Programme for Contaminants and Risks,

Finnish Environment Institute,

P.O. Box 140, 00251 Helsinki, Finland opposite in sign. At the mossy forest floor site, the extrapolated TGM emissions were $130 \%$ of the $\mathrm{Hg}$ deposition in August 2007. Comparison with other studies showed that the fluxes in background areas are relatively uniform, regardless of measurement site location and method used. Airborne TGM remained at the background level during the study, with an average value of $1.3 \pm 0.2 \mathrm{ng} \mathrm{m}^{-3}$; it frequently showed a diurnal cycle pattern.

Keywords Total gaseous mercury · Air-surface exchange $\cdot$ Flux chamber $\cdot$ Deposition

\section{Introduction}

Unlike other toxic metals, mercury is highly volatile and has low water solubility. Elemental mercury, which is the most abundant species in the atmosphere in background areas, has an atmospheric lifetime of 0.5-2 years (Schroeder and Munthe 1998), resulting in global dispersion of this component. There are several anthropogenic sources for mercury, mainly coal combustion, waste incineration, metal smelting, refining and manufacturing. Not only can mercury be emitted from anthropogenic sources but also from natural surfaces, such as water bodies, soil and vegetation. Thus, gaseous mercury is readily transported from aquatic and terrestrial ecosystems into the atmosphere (Schroeder et al. 1989). The contribution of the $\mathrm{Hg}$ emission from soils is important to the 
global Hg cycle (Carpi and Lindberg 1998). To study the fate of mercury that has been emitted into the atmosphere, atmospheric flux measurements are needed.

The $\mathrm{Hg}$ flux from, e.g. the soil is influenced by solar radiation (Poissant and Casimir 1998; Bahlmann et al. 2004a), soil and air temperature (Gustin et al. 1997; Poissant and Casimir 1998), soil moisture (Bahlmann et al. 2004b), wind speed (Gustin et al. 1997), ozone (Engle et al. 2005) and possibly even unknown substance(s) in the ambient air (Zhang et al. 2008). The emission rate limiting factors are the abiological and biological formation of $\mathrm{Hg}^{0}$ (and $\left.\left(\mathrm{CH}_{3}\right)^{2} \mathrm{Hg}\right)$ in the uppermost soil layers in background areas, and thus, the evaporation rate is probably also strongly influenced by deposited airborne mercury (Schlüter 2000). Given the situation of climate warming and the shorter duration of snow cover in large areas of the boreal forest zone, terrestrial mercury emissions will probably change in the future.

Both flux chambers (Xiao et al. 1991; Carpi and Lindberg 1998; Schroeder et al. 2005; Kuiken et al. 2008a, b) and micrometeorological methods (Kim et al. 1995; Lindberg et al. 1998, 2002; Lee et al. 2000; Poissant et al. 2004; Schroeder et al. 2005) have been widely used in studies of mercury fluxes. At the moment, no standard protocol for flux measurements exists and therefore a wide variety of measurement conditions have been applied (e.g. Eckley et al. 2010). Micrometeorological methods (MM) have relatively large flux footprints and do not interfere with the surface of interest. They are also desirable when the substrate concentration varies greatly over the measurement site, since the flux chamber technique (FC) has a limited footprint. Disadvantages of the MM methods include the demand for a developed infrastructure, especially at a forested site, where towers several tens of metres in height are needed. Often these methods also require an electricity supply and relatively easy access to the measurement site (Rinne 2001). FCs are practical due to their low cost, portability and ease of use. With chamber techniques, the measurement can be carried out on a certain surface instead of a whole ecosystem, and lower emission rates can be detected.

In North America, a vast number of flux experiments from various surfaces have been conducted and published (e.g. Lindberg et al. 1995, 1998, 1999; Gustin et al. 1997; Carpi and Lindberg 1998; Poissant and Casimir 1998; Edwards et al. 2001; Schroeder et al. 2005; Kuiken et al. 2008a, b). However, on other continents, data are scarce. To our knowledge, background flux data for the Eurasian boreal zone are provided in only a few papers (Schroeder et al. 1989; Xiao et al. 1991; Lindberg et al. 1998).

The aim of this work was to study atmospheric mercury fluxes at a background site and compare the amount of mercury being released and taken up by the forest and wetland surfaces. Since the Nordic countries are highly forested, the fluxes occurring in such background areas are of interest. Air concentrations were measured to ensure background conditions at the site. This work was conducted as a part of a study to calculate the total mercury budget at a forested natural reserve in southern Finland in 2007.

\section{Experimental}

\subsection{Site Description}

The study site is located at Lammi in southern Finland $\left(61^{\circ} 14^{\prime} \mathrm{N}, 25^{\circ} 04^{\prime} \mathrm{E}\right)$ in the southern boreal zone (Fig. 1). It is a forested (about $66 \%$ of the total area) natural reserve with a small headwater lake and some wetland areas (about $21 \%$ of the total area). The area is dominated by Norway spruce (Picea abies) with some old birch (Betula spp.), aspen (Populus tremula) and Scots pine (Pinus sylvestris) trees occurring among the spruce. The mineral soils in the catchments are predominately Podzols developed in shallow glacial drift (till) deposits (Mäkelä 1995; Starr and Ukonmaanaho 2001). The catchment is part of the UN/ECE ICP-Forests and ICP IM monitoring programme in Finland.

The flux experiments were carried out at three different locations. The first one (here called L1) was located near the lake at the bottom of a small hill, the second one (L2) was on a hillside some $40 \mathrm{~m}$ uphill from L1, while the third one (L3) was sited at a small wetland a couple of hundred metres from the other two sites. The total gaseous mercury (TGM) concentration in the air was measured at L1, while the mercury bulk deposition was collected at L3. The L1 plot contained moss (Sphagnum), grass and some brushwood and litter. The L2 plot was covered with litter, with some twigs and brushwood. The L3 site 


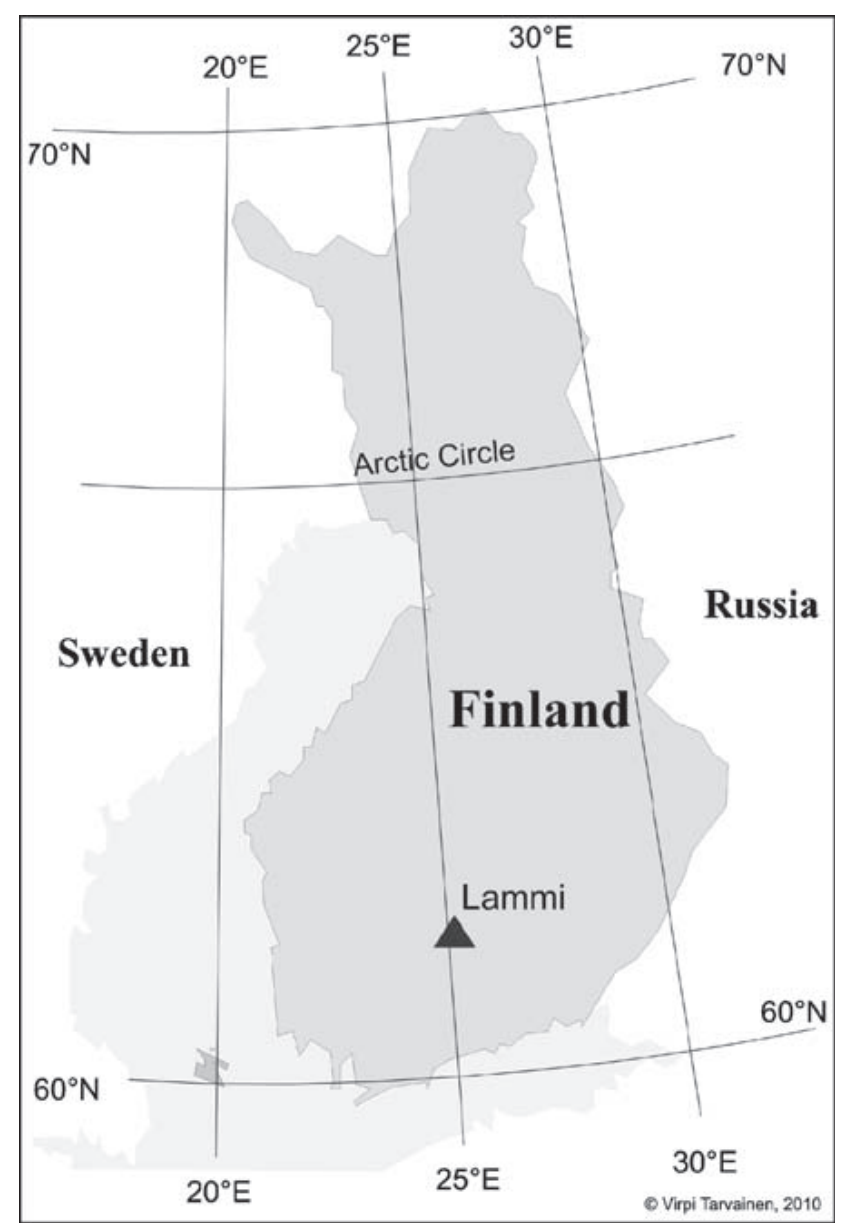

Fig. 1 Location of the study site

consisted of three adjacent plots with (1) mostly moss (Sphagnum) and some grass, (2) grass, moss and cranberry and (3) moss and grass with some litter and cranberry. The mean $\mathrm{Hg}$ concentration in the soil humus layer was $0.25 \mathrm{mg} / \mathrm{kg}$ (dry weight, $\mathrm{dw}$ ), while in the mineral soil below $(0-25 \mathrm{~cm})$, it was 0.03 $\mathrm{mg} / \mathrm{kg}$ (dw) (data: Finnish Environment Institute).

The experiments were carried out between April and September of 2007, most of them in August. The air temperature during the experiment days varied between $6^{\circ} \mathrm{C}$ and $26^{\circ} \mathrm{C}$, while the ground temperature rose from $0^{\circ} \mathrm{C}$ in April to $15^{\circ} \mathrm{C}$ in late summer. There was hardly any precipitation during the experiment days (less than $1 \mathrm{~mm}$ in August and $2.8 \mathrm{~mm}$ on May 3). The total monthly precipitation in August was $78 \mathrm{~mm}$ at a nearby weather station $7 \mathrm{~km}$ from the study site. In general, the temperature and rain amount were close to their average values throughout the summer of 2007, according to the statistics of the Finnish Meteorological Institute (FMI).

\subsection{Sampling}

The first experiment was carried out shortly after the snow melt in April 2007, and the last was in early September, well before the first snowfall. In total, there were eight different experiment days with one to six measurements on each, resulting in 49 separate flux measurements. At L1, experiments were carried out on all 8 days $(N=33)$ while at L2 and L3, there were four $(N=8)$ and three $(N=8)$ experiment days, respectively, due to the logistical difficulties in a forested natural reserve. On each measurement occasion, two to three "replicate" samplings were conducted. These so-called replicates were separate flux measurements performed successively and thus do not represent exactly the same conditions. Generally, the daily experiments consisted of two successive measurements at one or at all three different locations. In late August, to study diurnal variation, the experiments were performed every third hour around the clock. The concentration of TGM in the air was measured for 1 month from 6 August to 6 September.

The sampling system consisted of a Teflon flux chamber connected to a Tekran 2537A mercury vapour analyser. Both Teflon and polycarbonate chamber designs have been widely used in TGM flux measurements (e.g. Carpi and Lindberg 1998; Eckley and Branfireun 2008; Kuiken et al. 2008a, b; Zhang et al. 2008). However, Teflon has been the recommended choice of material in recent comparison studies (Carpi et al. 2007; Eckley et al. 2010). In this study, the dimensions of the flux chamber, made of 0.05 mm-thick fluorinated ethylene propylene, were $60 \times$ $60 \times 25 \mathrm{~cm}(l \times w \times d)$. The relatively large square area of the chamber gives more reliable results for the flux from a chosen surface compared to most typical mercury flux chamber designs (Eckley et al. 2010 and references therein). Additionally, a large enough chamber was indeed needed in this particular study due to the growing low vegetation. The chamber had an external aluminium frame support. A similar method has been previously employed for, e.g. hydrocarbon emissions; a more detailed description can be found in Hellén et al. (2006). At L1 and L2, the chamber was seated on a stainless steel collar set in the ground 4 months before the first measurements started. The collars remained undisturbed during the whole measurement period. A water bath of ultrapure Milli-Q water between the chamber and collar sealed 
the system. At L3, no collar was used, since the chamber could easily be pressed into the vegetation surface.

The Tekran mercury analyser collects and analyses samples continuously at 5-min intervals using two gold cartridges in turn. While one cartridge is collecting a sample, the other is being desorbed and the mercury in the sample analysed by atomic fluorescence spectrometry. The analyser collects only total gaseous mercury and not particles, which were removed from the sample flow with a Teflon filter (diameter $47 \mathrm{~mm}, 0.2 \mu \mathrm{m}$ pore size). The sample flow rate was $1.5 \mathrm{~L} \mathrm{~min}^{-1}$, and the carrier gas was argon 6.0 (purity $99.9999 \%$ ). With these parameters, a detection limit of $0.1 \mathrm{ng} \mathrm{m}^{-3}$, a repeatability of $2 \%$ and a measurement uncertainty of $10 \%$ are achieved. The analyser was calibrated daily at the site with its internal permeation source. This instrument model has been used successfully at a number of locations around the world and has been found to give results comparable to those with other methods (Ebinghaus et al. 1999).

The chamber and analyser were connected with Teflon tubing. The method was almost static, i.e. no ventilation was performed in the chamber, but the sample flow of $1.5 \mathrm{Lmin}^{-1}$ was estimated to mix the air in the chamber effectively. Also, a narrow open Teflon tube connected the chamber with the outside air to avoid the formation of under-pressure. This dilution was taken into account in the flux calculations. A static method such as this excludes the wind effect, which might underestimate the actual flux in normal conditions due to an increased groundair boundary layer. However, very low fluxes have been reported to present considerable challenges with dynamic chambers using fast turnover times due to (1) comparable blank and flux results and (2) flux values pushing the limits of instrumental detection (Kuiken et al. 2008a). With very low fluxes, the static method is more useful, since the concentration is not diluted in the method. The static method can, however, diminish the concentrations if the closing time is too long. Pumpanen et al. (2004) have shown that for $\mathrm{CO}_{2}$, a 10 -min closing time gave very good results, whereas the fluxes were underestimated by $10-15 \%$ when the closing time was extended to $30 \mathrm{~min}$. Our chamber remained closed for $20 \mathrm{~min}$, so this effect would not cause large errors in the measurements.
The emission rate was determined from the concentration increase in the chamber during a closure. The optimized experiment time of $20 \mathrm{~min}$ allows for four 5-min samples and consequently five data points (four samples plus the background value). When the linearity of the concentration increase was poor $\left(R^{2}<0.8\right)$, the results were rejected. Out of the total of 49 experiments, 13 results were omitted, 12 of which were considered as showing no flux. When a concentration change (i.e. a change greater than $0.1 \mathrm{ng} \mathrm{m}^{-3}$, which is about the absolute MU) was observed, the correlation coefficients were above the limit value in all cases, except in just one out of the total of 49 experiments. The average values for $R^{2}$ were 0.95 for L1, 0.93 for L2 and 0.90 for L3.

Hg blanks with the chamber and stainless steel collar were performed in the laboratory. The chamber system was placed on top of a Teflon film, and the $\mathrm{Hg}$ concentration inside the chamber was compared to that in the lab air $\left(1.9 \mathrm{ng} \mathrm{m}^{-3}\right)$. No significant difference was found, and therefore, no blank value was subtracted from the flux results. When not in use, the chamber was stored in a plastic bag in the laboratory with a TGM air concentration of less than $3 \mathrm{ng} \mathrm{m}^{-3}$ (usually close to ambient, i.e. less than $\left.2 \mathrm{ng} \mathrm{m}^{-3}\right)$.

Air temperature was measured with a Davis Vantage Pro 2 station, while the temperature inside the chamber and the solar radiation over the chamber were measured with a Li-Cor 190 SB sensor. The air temperature was observed to increase in the chambers during the closure. The increase was insignificant $(\Delta T<$ $2^{\circ} \mathrm{C}$ ) in most cases, since there was seldom direct sunlight in the whole plot area, due to cloudy weather and/or the shading of the canopy. The data for solar radiation are not discussed in this article due to instrumental failures.

The deposition samples were collected at L3 with an IVL-type bulk collector (funnel diameter $15 \mathrm{~cm}$ ) except during the winter months (December to April), when a wide Teflon funnel $(100 \times 100 \mathrm{~cm})$ was used for the collection of snow $10 \mathrm{~m}$ from the L2 site. For the precipitation amount, data from a nearby FMI station were used. Two samples were collected in parallel on a monthly basis; these were then shipped to the Swedish Environmental Research Institute (IVL) for analysis according to the EMEP manual (EMEP/CCC 2002). 


\subsection{Calculation of Hg Flux}

The Hg flux $F$ was calculated according to Eq. 1:

$F=\frac{\frac{\Delta c}{A} V}{t}$

where $\Delta c$ is the concentration change during the experiment, $A$ is the plot area, $V$ is the flux chamber volume and $t$ is the duration of the experiment. The dilution volume for each data point was taken into account.

\section{Results and Discussion}

\subsection{Forest Floor Emissions}

The forest floor fluxes for locations L1 and L2 are given in Fig. 2. The fluxes varied between -1.0 $3.5 \mathrm{ng} \mathrm{m}^{-2} \mathrm{~h}^{-1}$, being mainly positive, i.e. $\mathrm{Hg}$ was emitted from the forest floor. On some occasions ( $29 \%$ of samples), no flux was detected, while a negative flux was observed only rarely $(7 \%$ of samples). The low flux rates were partially a result of poor light penetration through the forest canopy and frequent cloudy days (see discussion below). In August, when the majority of the experiments were conducted, an average flux of $0.9 \pm 1.2 \mathrm{ng} \mathrm{m}^{-2} \mathrm{~h}^{-1}$ has been calculated from the measured values. Fluxes at L1 were always greater than at L2, with a maximum difference of $1.8 \mathrm{ng} \mathrm{m}^{-2} \mathrm{~h}^{-1}$ during 1 day. This is likely to be due to the different plot vegetations and to differences in solar radiation affecting the chamber plot, since the substrate $\mathrm{Hg}$ concentration is expected to be fairly consistent in the study area. The L1 plot was rich in mossy vegetation, while the L2 plot was covered with forest litter and was much dryer than L1. Also, the L1 plot was at the bottom of a slope, while L2 was up on the hillside. Consistent with our study, Kuiken et al. (2008a) reported very low fluxes from a litter-covered forest floor in Tennessee $(37 \%<0.2$ and $19 \%<0.0 \mathrm{ng} \mathrm{m}^{-2} \mathrm{~h}^{-1}$ ). Xiao et al. (1991) postulated that when the forest soil is covered with litter, any $\mathrm{Hg}$ emanating from the soil might be trapped by litter via direct adsorption or via the formation of complexes with humic materials.

In the spring, when the soil temperature was close to zero, the fluxes at L1 were negligible or very small. By early August, the soil temperature had increased, as had also the emissions. Rainless weather or only slight rainfall was recorded before and during the experiments. On 6 September, no exchange of $\mathrm{Hg}$ was detected at the L2 site. Mercury deposition from the air to the soil was recorded once at both sites. This occurred on the coldest days: During the negative flux experiments, temperatures were $+6.5^{\circ} \mathrm{C}$ and $+10^{\circ} \mathrm{C}$ at $\mathrm{L} 1$ and L2, respectively. The average relative deviation of successive flux measurements was $16 \%$ at L1.

The correlation between the $\mathrm{Hg}$ flux and other parameters (air temperature, soil temperature) was calculated for L1. At the L2 (and L3) plot, there were not enough flux data to make such calculations. The flux pattern was found to follow the air temperature (Figs. 2 and 4); the correlation at L1 is shown in Fig. 3. A linear relationship gave an $R^{2}$ value of 0.86 , similarly to the exponential relationship. The latter does not accept zero and negative values, resulting in slightly biased data; for this reason, the linear relationship is presented in Fig. 3. An exponential correlation between $\mathrm{Hg}$ flux and soil temperature has been found by Lindberg et al. (1995) and Gustin et al. (1997) over contaminated and naturally enriched soils. Gustin et al. (1997) reported a similarity between the $\mathrm{Hg}^{0}$ vapour pressure curve and the mercury flux curve and concluded that the $\mathrm{Hg}^{0}$ flux as a function of temperature is strongly influenced by the vapour pressure of $\mathrm{Hg}^{0}$.

Gustin et al. (1997) found that the $\mathrm{Hg}$ flux is greater when a substrate is indirectly heated by the air than when the substrate itself is directly heated with tape. They therefore suggested that the predominant processes driving the flux of $\mathrm{Hg}^{0}$ to the atmosphere as a function of temperature are those acting on the soil surface. In our study, the $\mathrm{Hg}$ flux correlated more strongly with air temperature $\left(R^{2}=0.86\right)$ than with soil temperature $\left(R^{2}=0.56\right)$. However, the soil temperature was measured only at a depth of $10 \mathrm{~cm}$; it is expected that the temperature of the top layer of soil was more affected by the air temperature than by the measured soil temperature.

The diurnal flux variation was studied on 30 and 31 August. Two sequential experiments were performed at an interval of approximately $3 \mathrm{~h}$; these produced 18 flux results (Fig. 4). The highest emission $\left(0.7 \mathrm{ng} \mathrm{m}^{-2} \mathrm{~h}^{-1}\right)$ occurred at $5 \mathrm{p} . \mathrm{m}$. on 30 August and 11 a.m. on 31 August, when the air temperature was the highest. The soil temperature at a depth of $10 \mathrm{~cm}$ did not change during the experiment. 
Fig. 2 Forest floor emissions and air temperatures at $\mathrm{L} 1$ (a) and L2 (b). Flux 1 and Flux 2 denote sequential measurements. A missing bar indicates no flux

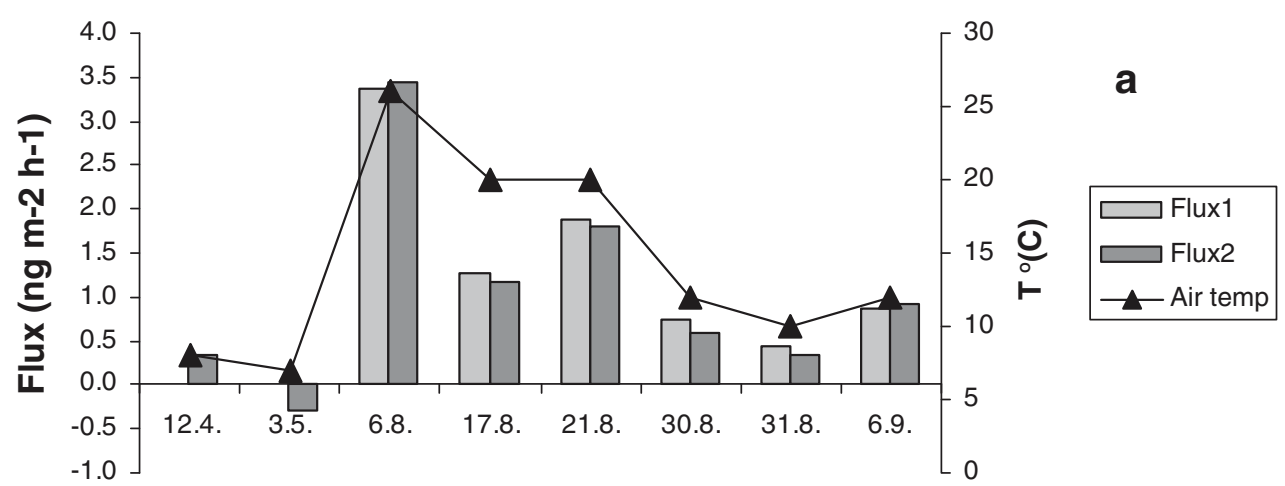

Date

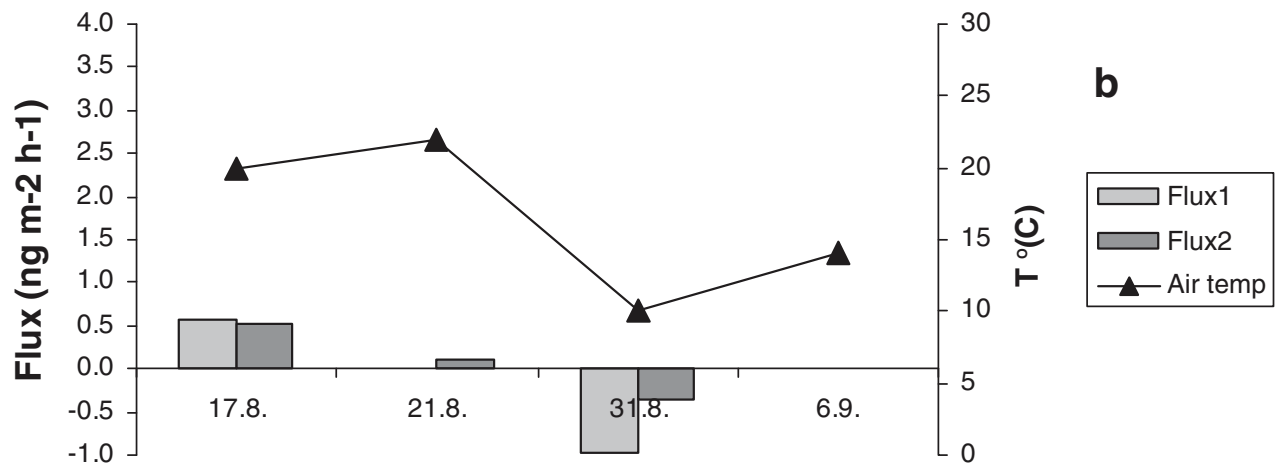

Date
Towards nightfall, the flux decreased, and during the early morning hours ( 2 and 8 a.m.), the concentration change in the chamber was unclear $\left(R^{2}<0.8\right)$, and thus, the flux was considered to be negligible. The flux results for which the concentration change correlation was below 0.8 are included in the figure (the hatched bars), but the measurement uncertainty is high for these results. Apart from one data point in the early morning (5 a.m.), which is in the same range as the daytime fluxes, the diurnal cycle is very clear. Between 4 and 6 a.m., the wind speed decreased to $0 \mathrm{~m} / \mathrm{s}$; the lack of wind probably produced an increased concentration of $\mathrm{Hg}$ above the soil. It should be noted that sunrise occurred after 6 a.m. at the site. At 11 a.m., there was a large variation between the sequential experiments as a result of temporary solar radiation differences affecting the chamber plot.
Fig. 3 Correlation between $\mathrm{Hg}$ flux and air temperature at L1

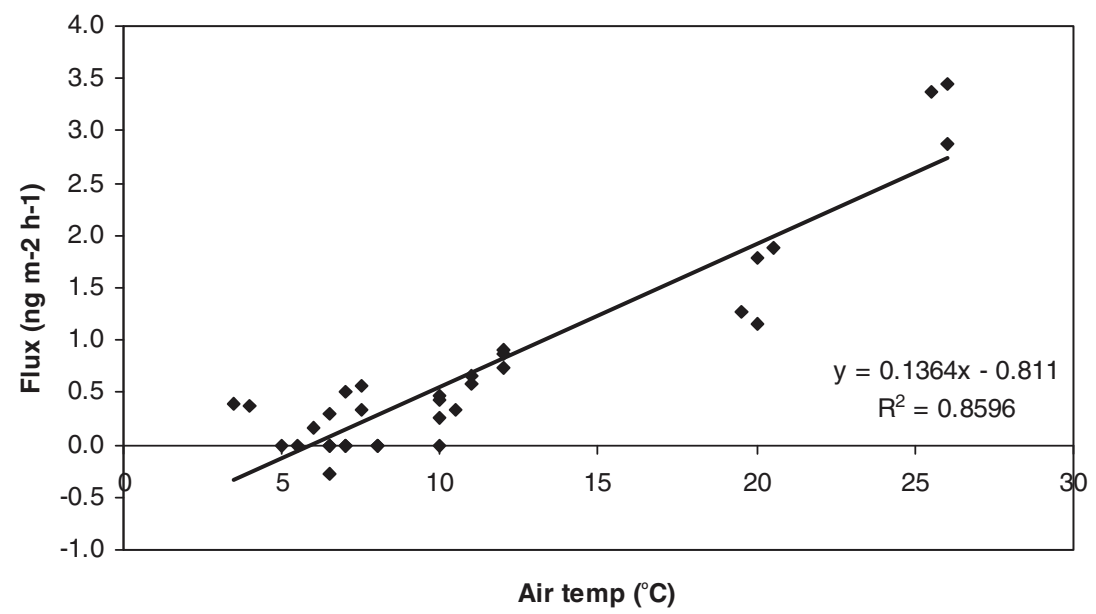


Fig. 4 Twenty-four-hour flux measurements at L1. The bars represent fluxes and the triangles air temperature. The hatched bars are flux results with a high uncertainty

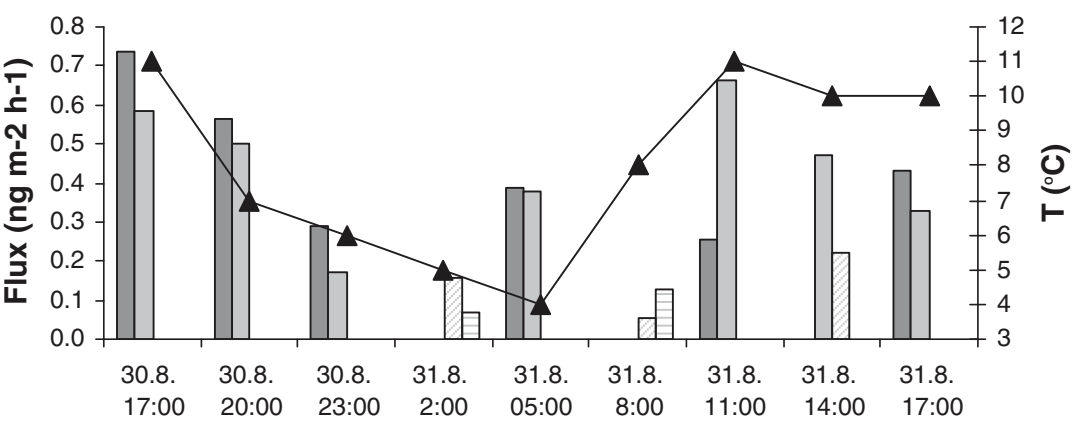

Date
The diel cycle is often associated with diurnal changes in, e.g. temperature and solar radiation (e.g. Poissant and Casimir 1998). Other parameters can also affect this behaviour. Zhang et al. (2008) hypothesized that some unidentified airborne substance(s) in the ambient air, such as ozone or some volatile organic molecules, might be responsible for the cycle. This was studied with contaminated soils held in the dark at a constant temperature in laboratory conditions. In the study, meteorological factors including wind speed were excluded.

\subsection{Wetland Emissions}

The fluxes at the three wetland plots are shown in Fig. 5. Here, the surface acted both as a source and as a sink. However, the fluxes were very small $(-0.3-$ $0.6 \mathrm{ng} \mathrm{m}^{-2} \mathrm{~h}^{-1}$ ), even though the measurement days at the wetland plots were generally warm and sunny. During the closures at the wetland plots, moisture condensed on the chamber walls; the condensed water vapour may have affected the flux results by inhibiting UV penetration into the chamber and absorption of $\mathrm{Hg}^{0}$ into the condensation droplets. Thus, the wetland results are discussed only briefly here. At the forest floor plots, no condensation occurred.
The wetland plots differ greatly from those on the forest floor, not only in respect to their vegetation but also by their moisture content. Soil moisture was not measured during the study, but visually it was clear that the forest floor plots were dry soil while the wetland plots were wet. The wet conditions may have inhibited the flux. A similar behaviour in the case of a wet forest canopy has been reported by Lindberg et al. (1998). They suggested that $\mathrm{Hg}^{0}$ dry deposition to the canopy may be enhanced by the presence of moisture, but that a wet canopy does not necessarily result in net deposition.

During the last measurement day, it rained slightly. Lindberg et al. (1999) discovered that after a heavy rainfall, the mercury emissions increased sharply in a geothermal area in Nevada, USA. In our study, the small rain amount did not change the already wet conditions, and no increased flux was observed.

\subsection{Comparison with Other Studies}

Fluxes between the air and various surface types have been reported in many North American studies (e.g. Lindberg et al. 1995, 1998, 1999; Gustin et al. 1997; Carpi and Lindberg 1998; Poissant and Casimir 1998; Edwards et al. 2001; Schroeder et al. 2005; Kuiken et
Fig. 5 Wetland fluxes and air temperatures at L3. Plot 1, plot 2 and plot 3 denote the adjacent experiment plots. A missing bar indicates no flux

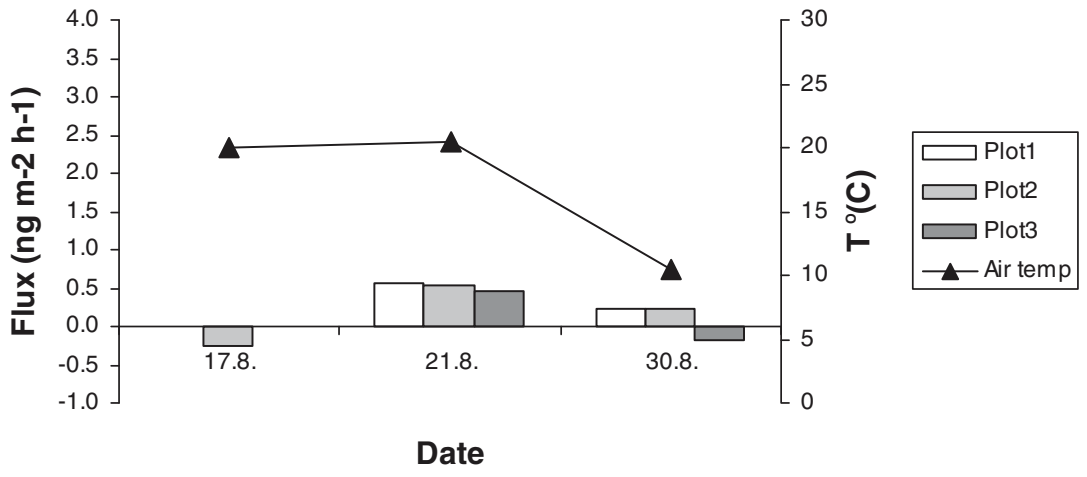


al. 2008a; b). In background areas, studies are still scarce. To our knowledge, mercury flux measurements have been performed in the Eurasian boreal zone only in Sweden (Schroeder et al. 1989; Xiao et al. 1991; Lindberg et al. 1998) prior to our measurements. A comparison of flux results in background areas is presented in Table 1. The spring data from our study with only a few data points at L1 have been excluded from the table.

Our soil results are very similar to the Swedish and Canadian studies (Xiao et al. 1991; Lindberg et al. 1998; Poissant and Casimir 1998; Schroeder et al. 2005), which could be expected due to the similarities in vegetation and latitude. The flux values obtained in the American studies by Kuiken et al. (2008a, b) are also similar to ours. Although the flux depends on the various parameters listed previously, the fluxes are relatively uniform regardless of the measurement site location and measurement method. However, the measurements are mostly conducted during the warm summer period characterized by higher temperatures and high solar radiation. The estimation of annual net fluxes is therefore problematic due to the lack of winter-time measurements.

A comparison of fluxes measured at different wetland locations is given in Table 2. For the wetland, our results are in the low range and similar to studies by Lee et al. (2000) and Schroeder et al. (2005). The areas in the Lindberg et al. (2002) and Poissant et al. (2004) studies were impacted by agricultural, municipal and industrial activities, and thus, higher fluxes at those sites are to be expected. To our knowledge, our mercury flux measurements are the first to be conducted in a Eurasian boreal wetland.

\subsection{Emission vs. Wet Deposition}

To evaluate the mercury transport at the atmospheresoil interface, bulk deposition data were compared to the flux results. The monthly Hg deposition in 2007, as monitored by the Finnish Environmental Institute, is shown in Fig. 6.

The bulk deposition in August was $780 \mathrm{ng} \mathrm{m}^{-2}$, which represents a typical deposition amount in late summer. This value was compared to the calculated average monthly $\mathrm{Hg}$ flux at the site L1. In August 2007, the average temperature at the nearby weather station was $+16^{\circ} \mathrm{C}$, while the 30 -year average was $14.2^{\circ} \mathrm{C}$ (FMI statistics). Using the temperature of

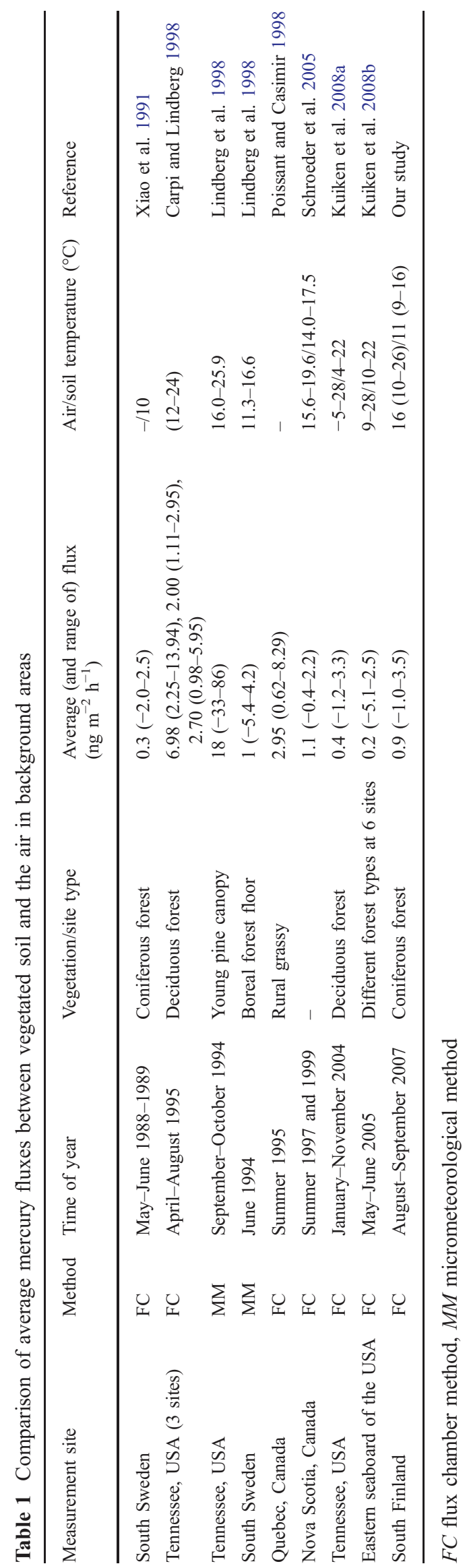




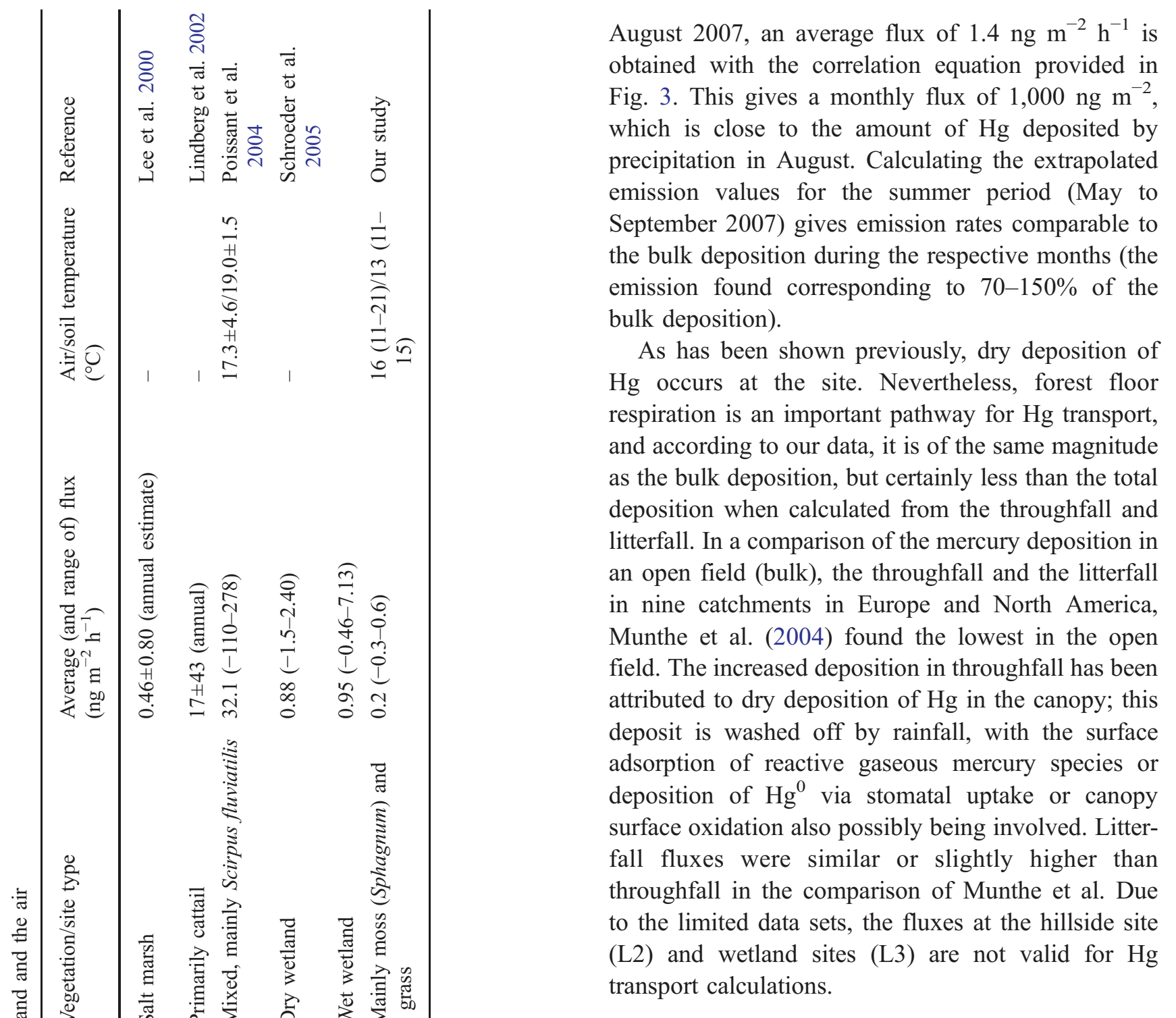

\subsection{Atmospheric Mercury Concentrations}

Ambient air concentrations were measured for a 1month period during the late summer experiment season (between 6 August and 6 September, Fig. 7). The Hg concentration in the air was rather low, with an average value of $1.3 \mathrm{ng} \mathrm{m}^{-3}$ and a maximum value of $2.2 \mathrm{ng} \mathrm{m}^{-3}$. On most days, a diurnal cycle was observed, with an early morning hour minimum and an afternoon maximum. Similar behaviour has been observed in Canada (Kellerhals et al. 2003), northern Taiwan (Kuo et al. 2006) and Mt. Gongga in China (Fu et al. 2008). Low concentrations (approximately $1.0 \mathrm{ng} \mathrm{m}^{-3}$ ) in the early morning hours of summer have also been detected in Sweden (Schmolke et al. 1999). Kellerhals et al. (2003) stated that the low concentrations resulted from nighttime depletion of 
Fig. 6 Monthly Hg deposition at Lammi in 2007 (data: Finnish Environment Institute)

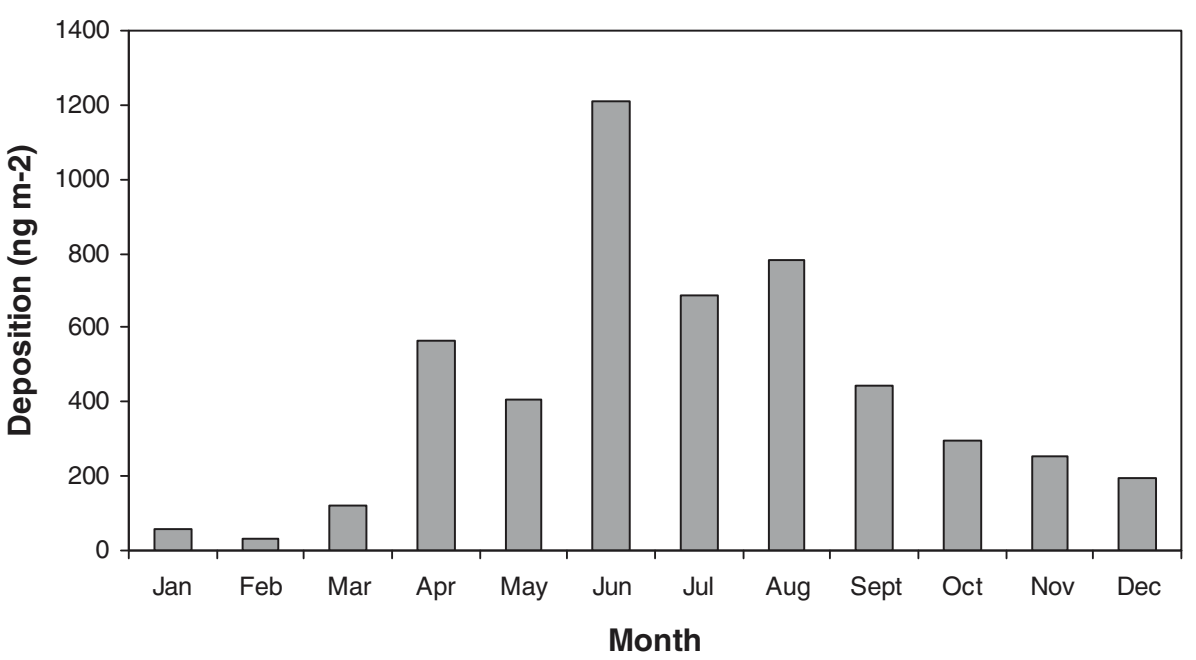

TGM in the lowermost atmosphere, where a shallow TGM-depleted layer is formed underneath the nocturnal inversion layer. Shortly after the sunrise, the nocturnal inversion breaks down, and this air is mixed with undepleted air. This phenomenon might also be happening at our site. Fu et al. (2008) hypothesized that their pattern is due to a strong surface source activated by solar radiation and air temperature at some locations and to wind direction at others. At our measurement site, clean northerly winds with low TGM concentrations were most dominant during the nighttime, but the southerly winds that are expected to carry air from the highly industrialized areas in Europe were almost as frequent. Thus, we conclude that the effect of wind direction is small but existing. The main reasons for the diurnal cycle at our site are believed to be the higher temperature and solar radiation during the day; these increase the surface emission and thus increase the air concentrations, while the nighttime depletion is responsible for the diurnal minimum. During the diurnal experiment, no uptake by the forest floor was detected. However, this does not exclude the possibility that mercury might be depleted to, e.g. the foliage. In conclusion, no atmospheric pollution sources affecting our flux study were observed.

\section{Conclusions}

Flux measurements were performed at two diverse forest floor and three adjacent wetland plots in the summer of 2007. Both emission and deposition were observed, although emission was far more frequent during the study. The fluxes at the forest floor sites were in the range $-1.0-3.5 \mathrm{ng} \mathrm{m}^{-2} \mathrm{~h}^{-1}$, with the fluxes at the verdant moss-grown plot always being higher than those at the litter-rich plot. The wetland fluxes were smaller $\left(-0.3-0.6 \mathrm{ng} \mathrm{m}^{-2} \mathrm{~h}^{-1}\right)$. The diurnal flux was measured at the verdant forest floor site; the flux was found to follow a clear diurnal pattern with a nighttime minimum and a daytime maximum. With the available data, a clear temperature dependence was evident. Since the measurements were limited to summer time, the real net balance is difficult to quantify. The ambient TGM concentration
Fig. 7 TGM concentration (black line) and daily mean temperature (grey line with triangles) at $\mathrm{L} 1$ during the late summer measurement campaign

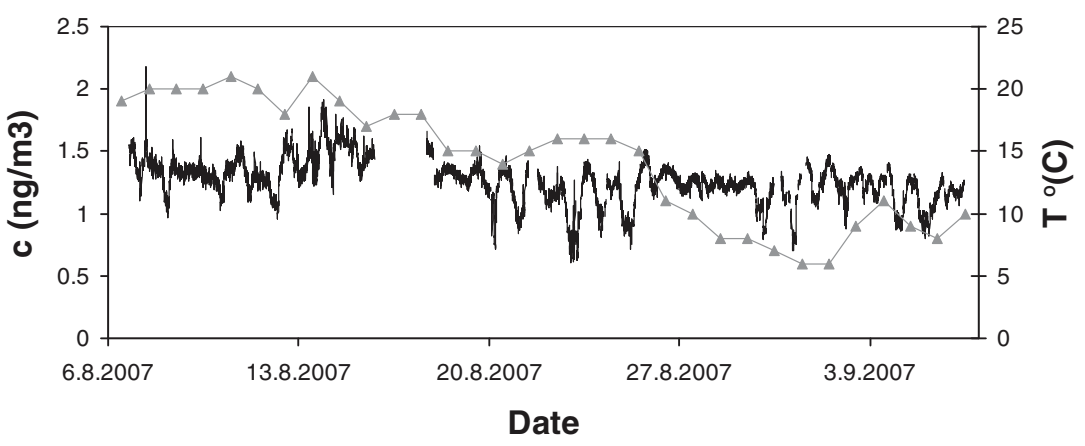


remained at roughly the background level throughout the campaign in late summer.

Forest floor respiration was found to be an important pathway for mercury transport. During August, when the majority of the experiments were performed, the average measured flux was $0.9 \mathrm{ng} \mathrm{m}^{-2} \mathrm{~h}^{-1}$, with the average extrapolated flux being $1.4 \mathrm{ng} \mathrm{m}^{-2} \mathrm{~h}^{-1}$ calculated from the temperature dependence equation. The latter flux value, which we believe represents the real exchange more realistically, is equal to $130 \%$ of the mercury deposited by precipitation during the same month.

Although the amount of available flux data has increased during the last decade, data have mainly been forthcoming from North America. Studies in background and contaminated areas, also from other areas than North America, are needed to understand the mercury cycle in the environment. In Finland, $70 \%$ of the land use, in total $230,000 \mathrm{~km}^{2}$ in surface area, is forest, so that emissions from the forest floor affect the total mercury budget greatly, even though the fluxes themselves seem small. Annually, 2-3\% of the forests are subject to felling activities (Finnish Forest Research Institute 2007). According to our preliminary data, forestry practises increase mercury fluxes significantly, and $\mathrm{Hg}$ has been proven to be effectively transported through different media (Porvari et al. 2003). Only 8\% of Finnish forests are protected as the studied site is. Hence, flux studies in forest management areas are of interest. Our future work includes measurements of fluxes in areas affected by forestry practises and includes the employment of micrometeorological methods.

\section{References}

Bahlmann E., Ebinghaus R., Ruck W. (2004a) Influence of solar radiation on mercury emission fluxes from soils. In 7th International Conference on Mercury as a Global Pollutant, June 27-July 2, 2004, Ljubljana, Slovenia. RMZ-materials and geoenvironment, 51 (pp 787-790).

Bahlmann E., Ebinghaus R., Ruck W. (2004b) The effect of soil moisture on the emission of mercury from soils. In 7 th International Conference on Mercury as a Global Pollutant, June 27-July 2, 2004, Ljubljana, Slovenia. RMZmaterials and geoenvironment, 51 (pp 791-794).

Carpi, A., \& Lindberg, S. E. (1998). Application of a Teflon ${ }^{\mathrm{TM}}$ dynamic flux chamber for quantifying soil mercury flux: Test and results over background soil. Atmospheric Environment, 32, 873-882.
Carpi, A., Frei, A., Cocris, D., McCloskey, R., Contreras, E., \& Ferguson, K. (2007). Analytical artifacts produced by a polycarbonate chamber compared to a Teflon chamber for measuring surface mercury fluxes. Analytical and Bioanalytical Chemistry, 388, 361-365.

Ebinghaus, R., Jennings, S. G., Schroeder, W. H., Berg, T., Donaghy, T., Guentzel, J., et al. (1999). International field intercomparison measurements of atmospheric mercury species at Mace Head, Ireland. Atmospheric Environment, 33, 3063-3073.

Eckley, C., \& Branfireun, B. (2008). Gaseous mercury emissions from urban surfaces: Controls and spatiotemporal trends. Applied Geochemistry, 23, 369-383.

Eckley, C. S., Gustin, M., Lin, C.-J., Li, X., \& Miller, M. B. (2010). The influence of dynamic chamber design and operating parameters on calculated surface-to-air mercury fluxes. Atmospheric Environment, 44, 194-203.

Edwards, G. C., Rasmussen, P. E., Schroeder, W. H., Kemp, R. J., Dias, G. M., Fitzgerald-Hubble, C. R., et al. (2001). Sources of variability in mercury flux measurements. Journal of Geophysical Research, 106(D6), 5421-5435.

EMEP/CCC (2002) Manual for sampling and chemical analysis. Revised November 2001. Kjeller: Norwegian Institute for Air Research (EMEP/CCC-Report 1/95). http://www. nilu.no/projects/ccc/manual/index.html. Cited 28 Oct 2009.

Engle, M. A., Gustin, M. S., Lindberg, S. E., Gertler, A. W., \& Ariya, P. A. (2005). The influence of ozone on atmospheric emissions of gaseous elemental mercury and reactive gaseous mercury from substrates. Atmospheric Environment, 39, 7506-7517.

Finnish Forest Research Institute. (2007). Forest Finland in brief. Helsinki: Pekan Offset Oy. ISBN 978-951-40-2048-3.

Fu, X., Feng, X., Zhu, W., Wang, S., \& Lu, J. (2008). Total gaseous mercury concentrations in ambient air in the eastern slope of Mt. Gongga, South-Eastern fringe of the Tibetan plateau, China. Atmospheric Environment, 42, 970-979.

Gustin, M. S., Taylor, G. E., Jr., \& Maxey, R. A. (1997). Effect of temperature and air movement on the flux of elemental mercury from substrate to the atmosphere. Journal of Geophysical Research, 102, 3891-3898.

Hellén, H., Hakola, H., Pystynen, K.-H., Rinne, J., \& Haapanala, S. (2006). $\mathrm{C}_{2}-\mathrm{C}_{10}$ hydrocarbon emissions from a boreal wetland and forest floor. Biogeosciences, 3, 167-174.

Kellerhals, M., Beauchamp, S., Belzer, W., Blanchard, P., Froude, F., Harvey, B., et al. (2003). Temporal and spatial variability of total gaseous mercury in Canada: Results from the Canadian Atmospheric Mercury Measurement Network (CAMNet). Atmospheric Environment, 37, 10031011.

Kim, K.-H., Lindberg, S., \& Meyers, T. (1995). Micrometeorological measurements of mercury vapor fluxes over background forest soils in Eastern Tennessee. Atmospheric Environment, 29, 267-282.

Kuiken, T., Zhang, H., Gustin, M., \& Lindberg, S. (2008a). Mercury emission from terrestrial background surfaces in the eastern USA. Part I: Air/surface exchange of mercury within a southeastern deciduous forest (Tennessee) over one year. Applied Geochemistry, 23, 345-355. 
Kuiken, T., Gustin, M., Zhang, H., Lindberg, S., \& Sedinger, B. (2008b). Mercury emission from terrestrial background surfaces in the eastern USA. II: Air/surface exchange of mercury within forests from South Carolina to New England. Applied geochemistry, 23, 356-368.

Kuo, T., Chang, C.-F., Urba, A., \& Kvietkus, K. (2006). Atmospheric gaseous mercury in Northern Taiwan. Science of Total Environment, 368, 10-18.

Lee, X., Benoit, G., \& Hu, X. (2000). Total gaseous mercury concentration and flux over a coastal saltmarsh vegetation in Connecticut, USA. Atmospheric Environment, 34, 4205-4213.

Lindberg, S. E., Kim, K.-H., Meyers, T. P., \& Owens, J. G. (1995). Micrometeorological gradient approach for quantifying air/surface exchange of mercury vapor: Tests over contaminated soils. Environmental Science \& Technology, 29, 126-135.

Lindberg, S. E., Hanson, P. J., Meyers, T. P., \& Kim, K.-H. (1998). Air/surface exchange of mercury vapor over forests - the need for a reassessment of continental biogenic emissions. Atmospheric Environment, 32, 895-908.

Lindberg, S. E., Zhang, H., Gustin, M., Vette, A., Marsik, F., Owens, J., et al. (1999). Increases in mercury emissions from desert soils in response to rainfall and irrigation. Journal of Geophysical Research, 104, 21879-21888.

Lindberg, S. E., Dong, W., \& Meyers, T. (2002). Transpiration of gaseous elemental mercury through vegetation in a subtropical wetland in Florida. Atmospheric Environment, $36,5207-5219$.

Mäkelä, K. (1995). Valkea-Kotinen. General features of the monitoring area. In I. Bergström, K. Mäkelä, \& M. Starr (Eds.), Integrated monitoring programme in Finland. First national report. Report 1:16. Helsinki: Ministry of the Environment, Environmental Policy Department.

Munthe J., Bishop K., Driscoll C., Graydon J., Hultberg H., Lindberg S.E., Matzner E., Porvari P., Rea A., Schwesig D., St Louis V., Verta M. (2004) Input-output of $\mathrm{Hg}$ in forested catchments in Europe and North America. In 7th International Conference on Mercury as a Global Pollutant, June 27-July 2, 2004, Ljubljana, Slovenia. RMZ-materials and geoenvironment, 51(2) (pp. 1243-1246).

Poissant, L., \& Casimir, A. (1998). Water-air and soil-air exchange rate of total gaseous mercury measured at background sites. Atmospheric Environment, 32, 883-893.

Poissant, L., Pilote, M., Xu, X., Zhang, H., \& Beauvais, C. (2004). Atmospheric mercury speciation and deposition in the Bay St. Francois wetlands. Journal of Geophysical Research, 109, D11301.

Porvari, P., Verta, M., Munthe, J., \& Haapanen, M. (2003). Forestry practices increase mercury and methyl mercury output from boreal forest catchments. Environmental Science \& Technology, 37, 2389-2393.

Pumpanen, J., Kolari, P., Ilvesniemi, H., Minkkinen, K., Vesala, T., Niinistö, S., et al. (2004). Comparison of different chamber techniques for measuring soil $\mathrm{CO}_{2}$ efflux. Agricultural and Forest Meteorology, 123, 159-176.

Rinne J. (2001) Application and development of surface flux techniques for measurements of volatile organic compound emissions from vegetation. Finnish Meteorological Institute contributions, 31, ISBN 951-697-545-3.

Schlüter, K. (2000). Review: evaporation of mercury from soils. An integration and synthesis of current knowledge. Environmental Geology, 39, 249-271.

Schmolke, S. R., Schroeder, W. H., Kock, H. H., Schneeberger, D., Munthe, J., \& Ebinghaus, R. (1999). Simultaneous measurements of total gaseous mercury at four sites on a $800 \mathrm{~km}$ transect: Spatial distribution and short-time variability of total gaseous mercury over central Europe. Atmospheric Environment, 33, 1725-1733.

Schroeder, W., \& Munthe, J. (1998). Atmospheric mercury-an overview. Atmospheric Environment, 32, 809-822.

Schroeder, W. H., Munthe, J., \& Linqvist, O. (1989). Cycling of mercury between water, air and soil compartments of the environment. Water, Air, and Soil Pollution, 48, 337-347.

Schroeder, W. H., Beauchamp, S., Edwards, G., Poissant, L., Rasmussen, P., Tordon, R., et al. (2005). Gaseous mercury emissions from natural sources in Canadian landscapes. Journal of Geophysical Research, 110, D18302.

Starr, M., \& Ukonmaanaho, L. (2001). Results from the first round of the integrated monitoring soil chemistry subprogramme. In L. Ukonmaanaho \& H. Raitio (Eds.), Forest condition in Finland. National report 2000. Research papers, 824 (pp. 140-157). Helsinki: Finnish Forest Research Institute.

Xiao, Z. F., Munthe, J., Schroeder, W. H., \& Lindqvist, O. (1991). Vertical fluxes of volatile mercury over forest soil and lake surfaces in Sweden. Tellus, 43B, 267-279.

Zhang, H., Lindberg, S. E., \& Kuiken, T. (2008). Mysterious diel cycles of mercury emissions from soils held in the dark at constant temperature. Atmospheric Environment, $42,5424-5433$. 
III 



\title{
Trends and source apportionment of atmospheric heavy metals at a subarctic site during 1996-2018
}

\author{
Katriina Kyllönen ${ }^{\text {a,* }}$, Mika Vestenius ${ }^{\text {a }}$, Pia Anttila ${ }^{a}$, Ulla Makkonen ${ }^{\text {a }}$, Minna Aurela ${ }^{c}$, \\ Ingvar Wängberg $^{\mathrm{b}}$, Michelle Nerentorp Mastromonaco ${ }^{\mathrm{b}}$, Hannele Hakola ${ }^{\mathrm{d}}$ \\ ${ }^{a}$ Finnish Meteorological Institute, Air Quality, P.O. Box 503, FI-00101, Helsinki, Finland \\ ${ }^{\mathrm{b}}$ IVL Swedish Environmental Research Institute, Gothenburg, 41133, Sweden \\ ${ }^{\mathrm{c}}$ Finnish Meteorological Institute, Aerosol Composition, P.O. Box 503, FI-00101, Helsinki, Finland \\ ${ }^{\mathrm{d}}$ Finnish Meteorological Institute, Atmospheric Composition Research, P.O. Box 503, FI-00101, Helsinki, Finland
}

\section{H I G H L I G H T S}

- Concentrations, trends and sources of heavy metals in particles were determined.

- Study included $\mathrm{Al}, \mathrm{As}, \mathrm{Cd}, \mathrm{Co}, \mathrm{Cr}, \mathrm{Cu}$, $\mathrm{Fe}, \mathrm{Mn}, \mathrm{Ni}, \mathrm{Pb}, \mathrm{V}$, and $\mathrm{Zn}$ in particulate matter.

- Five source factors were identified with positive matrix factorization.

- Concentrations of heavy metals decreased up to $64 \%$ in $1996-2018$.

- No increasing temporal trends were observed for the studied heavy metals.

\section{A R T I C L E I N F O}

\section{Keywords:}

Trace elements

Trends

Source apportionment

PMF

PM10

Pallas
G R A P H I C A L A B S T R A C T

\section{Source apportionment (PMF) Pallas 1996-2018}

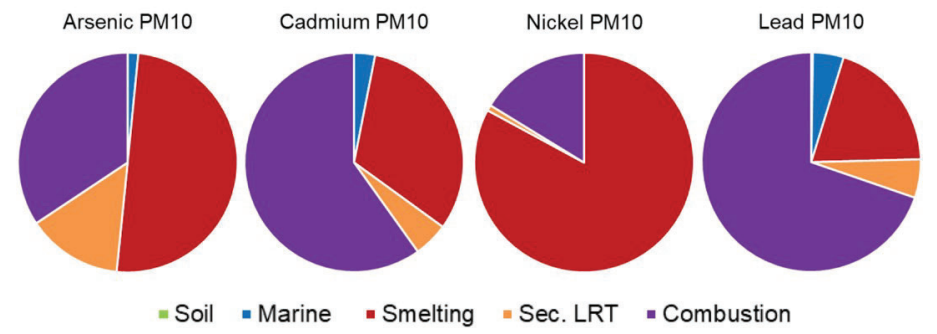

\begin{abstract}
A B S T R A C T
Atmospheric trace elements ( $\mathrm{Al}, \mathrm{As}, \mathrm{Cd}, \mathrm{Co}, \mathrm{Cr}, \mathrm{Cu}, \mathrm{Fe}, \mathrm{Mn}, \mathrm{Ni}, \mathrm{Pb}, \mathrm{V}, \mathrm{Zn}$ ) in particulate matter have been measured since 1996 at Pallas, a subarctic site in Finland. The results indicate a very low level of pollution as the concentrations were among the lowest measured in Europe. The annual average concentration during the whole time series (1996-2018), from the lowest values to the highest, was $\mathrm{Co}<\mathrm{Cd}<\mathrm{Cr}<\mathrm{As}<\mathrm{V}<\mathrm{Ni}<\mathrm{Cu}<\mathrm{Mn}<$ $\mathrm{Pb}<\mathrm{Zn}<\mathrm{Al}<\mathrm{Fe}$, ranging from 0.02 to $20 \mathrm{ng} \mathrm{m}^{-3}$. For the priority elements $\mathrm{As}$, $\mathrm{Cd}$, $\mathrm{Ni}$ and $\mathrm{Pb}$, the annual average concentration was $0.10,0.02,0.21$ and $0.65 \mathrm{ng} \mathrm{m}^{-3}$, respectively, in 2018. The concentrations were compared with the results from three other sites in Finland, and a clear south-to-north decreasing gradient was found for most elements except for $\mathrm{Ni}$, which was found to be mostly associated with emissions from the Kola Peninsula together with the trace elements of $\mathrm{Cu}$, As and $\mathrm{Co}$, as confirmed by the source apportionment analysis using positive matrix factorization. $\mathrm{Cd}, \mathrm{Pb}, \mathrm{V}$ and $\mathrm{Zn}$ were attributed to long-range transported (LRT) pollutants originating from combustion while $\mathrm{Al}, \mathrm{Fe}$ and $\mathrm{Mn}$ were related to the soil origin. Gaseous $\mathrm{Hg}$ was included in the source analysis and was found in a separate LRT and marine factors. Considering the full time series, a trend analysis showed statistically significant decreasing trends for $\mathrm{As}, \mathrm{Cd}, \mathrm{Co}, \mathrm{Cu}, \mathrm{Ni}, \mathrm{Pb}$ and $\mathrm{V}$ up to $64 \%$ in the whole period. Since 2010, six elements ( $\mathrm{Cd}, \mathrm{Co}, \mathrm{Ni}, \mathrm{Pb}, \mathrm{V}, \mathrm{Zn}$ ) have continued the positive development of declining
\end{abstract}

\footnotetext{
* Corresponding author. Finnish Meteorological Institute, Air Composition Research, P.O. Box 503, FI-00101, Helsinki, Finland.

E-mail addresses: katriina.kyllonen@fmi.fi (K. Kyllönen), mika.vestenius@fmi.fi (M. Vestenius), pia.anttila@fmi.fi (P. Anttila), ulla.makkonen@fmi.fi (U. Makkonen), minna.aurela@fmi.fi (M. Aurela), ingvar.wangberg@jormadesign.com (I. Wängberg), michelle.nerentorp@ivl.se (M. Nerentorp Mastromonaco), hannele.hakola@fmi.fi (H. Hakola).
} 
trends $(\mathrm{P}<0.05$ ) with changes between $25 \%$ and 53\% during the period. No statistically significant increasing trends were observed for the studied elements.

\section{Introduction}

It is well known that aerosols affect climate and human health. The chemical composition of aerosols in particular has a profound effect on the latter, and many heavy metals and metalloids found in the particulates, e.g., $\mathrm{Cd}, \mathrm{Pb}$ and $\mathrm{As}$, are considered toxic for humans and may cause health problems such as cancer and cardiovascular diseases after exposure. For some heavy metals, the chemical oxidation state determines the toxicity of the element (Suvarapu and Baek, 2017), e.g., As(III) is considered more toxic than As(V) (Yamauchi and Fowler, 1994). For Hg, the organic species (in particular $\mathrm{MeHg}$ ) are found to be more toxic than the inorganic species, however, health risks of mercury are nowadays mostly accounted for the chronic $\mathrm{MeHg}$ exposure through consumption of contaminated fish (Liu et al., 2012).

The sources of heavy metals vary significantly. Many trace elements are commonly released into the atmosphere through high-temperature processes. Major anthropogenic sources of trace elements include stationary fossil fuel combustion (e.g., As, Cd, Cr, Mn, Ni, V) and nonferrous metal production (e.g., As, $\mathrm{Cd}, \mathrm{Cu}, \mathrm{Zn}$ ) (Pacyna and Pacyna, 2001). Leaded gasoline combustion was traditionally considered to be the major source of $\mathrm{Pb}$, but industrial processes and the energy sector currently account for most of the Pb emissions in Europe (EEA, 2020; Pacyna and Pacyna, 2001). In the EEA-33 countries, road transport still generates $20 \%$ of $\mathrm{Pb}$ emissions as residual $\mathrm{Pb}$ in fuel, engine lubricants and parts, and tire and brake wear still contribute to the emissions (EEA, 2020). Several factors influence the proportion of aerosols being deposited locally or being transported far away from the source: particle size, temperature and speed of exhaust fumes, height of release, and prevailing winds and precipitation conditions (AMAP, 2005). Heavy metal emissions have decreased in recent decades (Pacyna et al., 2009), and for $\mathrm{Hg}$, the main emission areas have shifted from Europe and North America to Asia (Pirrone et al., 2010). From 1990 to 2017 in Europe, the $\mathrm{Cd}, \mathrm{Pb}$ and $\mathrm{Hg}$ emissions have decreased by $64 \%, 93 \%$ and $72 \%$, respectively, while in Finland, Cd has lowered by $86 \%, \mathrm{~Pb}$ by $95 \%$ and $\mathrm{Hg}$ by $47 \%$ (EEA, 2020). In the late 1990s and early 2000s, the EU has established the need to reduce pollution to levels that minimize harmful effects on human health and the environment as a whole and has thus set limit and target values for, e.g., As, $\mathrm{Cd}, \mathrm{Ni}$ and Pb in PM10 (EU, 1999, 2004, 2008, 2015).

The measurements of heavy metal bulk deposition started in Finland in 1980 as part of the former EGAP program (Group of Experts on Airborne Pollution of the Baltic Sea Area). This included the monitoring of lead and cadmium and was later expanded to ten other trace elements (Al, As, Co, Cr, Cu, Fe, Mn, Ni, V and Zn) at several stations. Nowadays, monthly trace element bulk deposition is routinely monitored at six background stations around the country (Kyllönen et al., 2009). The first measurements of heavy metals in particulate matter (PM) were typically conducted in urban and industrial areas starting in the late 1970s, whereas in background areas, the monitoring of atmospheric heavy metals started later in 1996. The first background site was located at Pallas, a subarctic area in Finnish Lapland, where twelve trace elements in PM10 were measured according to the Arctic Monitoring and Assessment Programme (AMAP). In 2007, PM10 measurements for trace elements were also started at two other locations to fulfill the EU air quality directive 2004/107/EC. In addition, short campaigns ( $\sim 1 \mathrm{yr})$ for heavy metals in different PM size fractions have been organized at the Finnish arctic sites (Virkkula et al., 1999; Paatero et al., 2008). Furthermore, historic filter samples dating back to the 1960s have been reanalyzed for heavy metals in particulate matter at one Finnish arctic site (Laing et al., 2014a; Yli-Tuomi et al., 2003). Mercury in deposition and in the air-both total gaseous mercury (TGM) and total particulate mercury (TPM) - have been monitored at Pallas since the late 1990s and early 2000s (Wängberg and Munthe, 2001). Since then, mercury monitoring has broadened to three other background sites in Finland in addition to some urban and industrial campaigns (Kyllönen et al., 2014; Saari et al., 2018).

This paper aims to present an overview of the concentration levels and changes of twelve trace elements in the ambient air collected at Pallas, Finland, in 1996-2018. These include aluminum, arsenic, cadmium, chromium, cobalt, copper, iron, lead, manganese, nickel, vanadium and zinc in the particulate matter. This 23-year-long dataset presents valuable information on how reduced emissions have affected the concentration trends of heavy metals at this remote location. The proximity of the heavy industrial areas in the Kola Peninsula, one of the main polluters in the Arctic area along with the Norilsk mining and metallurgical company, make this site one of special interest. In addition to concentration trends, source apportionment of trace elements by positive matrix factorization (PMF) analysis was studied. For PMF, mercury measurements were also considered.

\section{Experimental}

\subsection{Measurement sites}

The measurements were conducted at the subarctic site, Pallas, in Northern Finland (68.00 N, 24.24 E), which comprises several stations. The heavy metals were collected at the Pallas/Matorova station (Fig. 1), a site that is located approximately $170 \mathrm{~km}$ north of the Arctic Circle and is designated as a National Park. Its vegetation type is coniferous forest. The long-term monthly temperature average is $-14{ }^{\circ} \mathrm{C}$ for January and $14{ }^{\circ} \mathrm{C}$ for July (Lohila et al., 2015). The site is a remote background

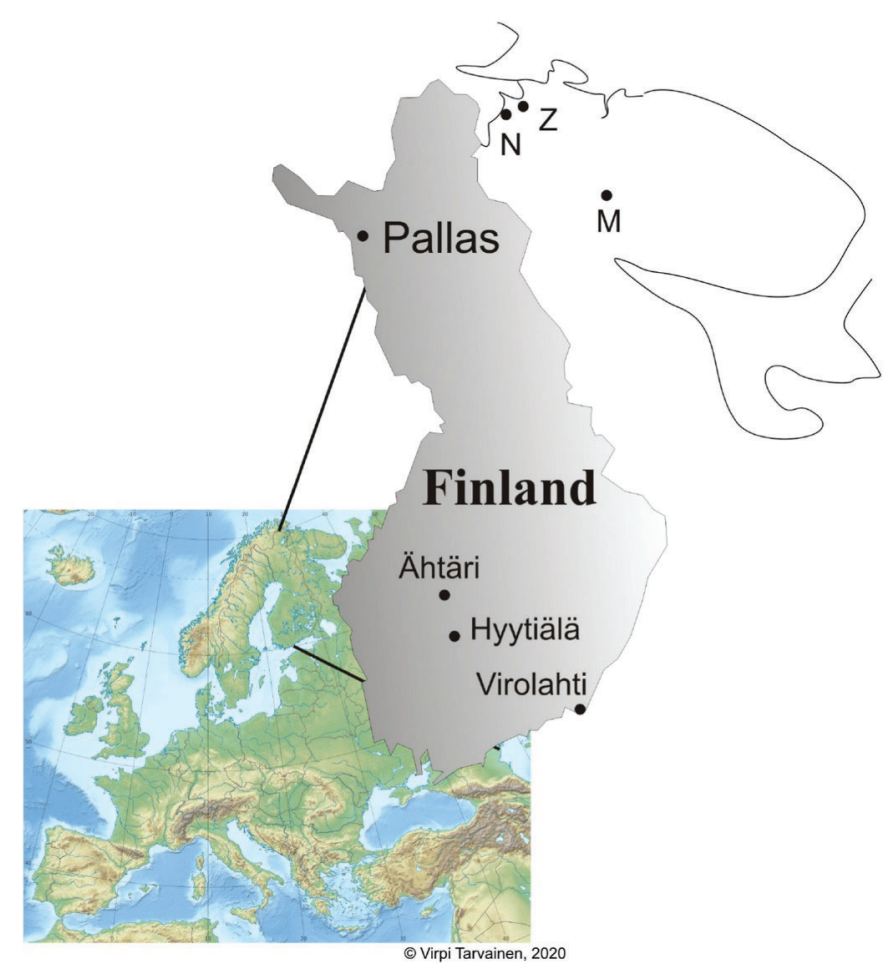

Fig. 1. Location of the measurement sites. The letters $N, Z$ and $M$ represent the potential sources Nikel, Zapoljarnij and Monchegorsk, which are non-ferrous smelters (primarily nickel and copper). 
station characterized by very low air pollutant concentrations (e.g., Anttila et al., 2016, 2010; Hyvärinen et al., 2011; Lohila et al., 2015; Raatikainen et al., 2015; Ruoho-Airola et al., 2015; Wängberg et al., 2010). However, the proximity of the copper-nickel industry in the Kola Peninsula $300 \mathrm{~km}$ NE of the station is considered a relevant source for some pollutants. The site contributes to several international programs such as the Arctic Monitoring and Assessment Programme (AMAP), the European Monitoring and Evaluation Programme (EMEP), the Global Mercury Observation System (GMOS), the International Cooperative Programme on Integrated Monitoring of Air Pollution Effects on Ecosystems (ICP IM) and the WMO Global Atmosphere Watch (GAW). The station is described in detail in Lohila et al. (2015). In addition, atmospheric heavy metals are measured at two other sites in Finland: the EMEP site Virolahti (60.53 N, 27.67 E) and the SMEAR II site (SMEAR: Station for Measuring Ecosystem-Atmosphere Relations) Hyytiälä (61.85 N, 24.30 E) since 2007 and 2017, respectively. Measurements were also performed at the EMEP site Ähtäri $(62.59 \mathrm{~N}, 24.19 \mathrm{E})$ in 2007-2016. These datasets were used for comparison for the Pallas data.

\subsection{Measurement methods}

Weekly filter samples for heavy metals (HM) were collected with a low-volume sampler with a flow rate of $1 \mathrm{~m} 3 / \mathrm{h}$ at Pallas. The filter material was Teflon (Millipore, Fluoropore, $3 \mu \mathrm{m}$, d $47 \mathrm{~mm}$ ). A PM10 inlet (IVL PModel S10) was introduced in 2007; prior measurements did not employ a particle size cut-off. The inlet was located at the roof of the measurement station at a height of $4 \mathrm{~m}$ above ground level. During 1996-2009, the filters were acid-digested in the FMI chemical laboratory with a solution of hydrogen fluoride (HF) and nitric acid $\left(\mathrm{HNO}_{3}\right)$ according to Jalkanen and Häsänen (1996). Since 2010, the filters' pretreatment was composed of a microwave-assisted acid digestion with $\mathrm{HNO}_{3}$ and hydrogen peroxide $\left(\mathrm{H}_{2} \mathrm{O}_{2}\right)$ according to EN 14902:2005 at the Finnish Environment Institute (FEI, method accredited according to ISO/IEC 17025 since 2016). The samples were analyzed with ICP-MS instruments (PerkinElmer Elan 5000/6000/DRCII, Thermo iCAPQ). Over the years, the laboratories have participated in the annual EMEP intercomparison exercise for heavy metals in synthetic precipitation, in the PM10 intercomparison by EU/JRC/IES in 2007 and in the development of particulate matter-certified reference materials (PM10 CRMs) by EU/JRC/IRMM (PAHs and trace elements) in 2007. Additionally, they have utilized frequently different standard reference materials (SRMs) (NIST SRM 1633b, 1648 and 1648a, NIES No. 8) as part of the quality control.

In Virolahti and Ähtäri, HM sampling was first started in 2007 with low-volume samplers and PM10 inlets. In Ähtäri, weekly samples were collected until the end of 2016, while in Virolahti, three $(2+2+3$ days $)$ or two ( $4+3$ days) samples per week were collected. In 2017, Ähtäri's measurements were relocated to Hyytiälä to benefit from the numerous other measurements in this SMEAR II site. The pretreatment and analysis of filters was the same for these stations as for Pallas.

\subsection{Supplementary measurements}

For the source apportionment with positive matrix factorization (PMF), the measurement data of the other atmospheric compounds routinely monitored at the site were utilized, including the EMEP filter pack results for selective water-soluble inorganic ions (WSII) collected at Pallas/Matorova: anions $\left(\mathrm{SO}_{4}^{2-}, \mathrm{NO}_{3}^{-}, \mathrm{Cl}^{-}\right)$, cations $\left(\mathrm{Ca}^{2+}, \mathrm{K}^{+}, \mathrm{Mg}^{2+}\right.$, $\left.\mathrm{Na}^{+}, \mathrm{NH}_{4}^{+}\right)$, and gases $\left(\mathrm{HNO}_{3}, \mathrm{NH}_{3}\right.$ and $\left.\mathrm{SO}_{2}\right)$. A term $\mathrm{NH}_{4}$ sum is used in this study to describe the sum of $\mathrm{NH}_{4}^{+}$and $\mathrm{NH}_{3}$ and, similarly, the $\mathrm{NO}_{3}$ sum, including both $\mathrm{NO}_{3}$ and $\mathrm{HNO}_{3}$, as these cannot be well separated with the sampling technique. The methods are described in detail in Ruoho-Airola et al. (2015), where the trends of these compounds have also been presented. In addition, TGM measurements at Pallas/Matorova were included in the PMF analysis, for which data collected with the manual sampling method were utilized for 1996-2007, while Tekran
2537 analyzer data were employed for 2008-2018. The methods for TGM are described in Wängberg and Munthe (2001) and Kyllönen et al. (2014). Also, elemental and organic carbon (EC/OC in PM2.5) data from 2014 to 2018 were used for the PMF analysis. For EC/OC method details, please see Bauer et al. (2009) and Cavalli et al. (2010). Hourly analyzer data for $\mathrm{PM} 10, \mathrm{O}_{3}, \mathrm{SO}_{2}$ and $\mathrm{NO}_{\mathrm{x}}$ from the Pallas/Sammaltunturi station (6 $\mathrm{km}$ from the Pallas/Matorova station) were also used as supportive data for PMF factor interpretation. The Sammaltunturi station is described in Lohila et al. (2015).

\subsection{Source apportionment}

The positive matrix factorization method (US EPA PMF 5.0) was used for the source apportionment of the chemical species in the averaged weekly samples. PMF needs two starting matrices: a data matrix including pollution time series and an uncertainty matrix, which consists of user-defined uncertainties for each data point in the data matrix.

PMF is a factor analysis tool that decomposes the sample data matrix into two matrices, i.e., factor contributions and factor profiles, which are the results of the PMF model. The model results are constrained so that there are no negative source contributions. The goal of the analysis is to identify a user-specified number of factors. The PMF method is described elsewhere (Paatero and Tapper, 1994; Paatero, 1997). The bootstrap (BS) method was used to estimate the error of PMF results (Paatero et al., 2014). The PMF summary table and the error estimation summary table are shown in the supporting documents (Tables A1-A3).

For some compounds, the measurements started after 1996, and artificial data were created to match the time series of HMs. These compounds were $\mathrm{Cl}, \mathrm{Ca}, \mathrm{K}, \mathrm{Mg}$ and Na starting in 2003 and EC/OC starting in 2014. The errors were set high to reduce the impact of these artificial values. For modelling, PM10 mass was calculated as the sum of individual chemical components (heavy metals, WSII, EC, OC), however, this value is slightly biased as EC/OC was measured in PM2.5.

The potential source contribution function (PSCF) was used for trajectory analysis using $120 \mathrm{~h}$ FLEXTRA air mass back trajectories (Stohl et al., 1995; Stohl and Seibert, 1998) calculated at NILU with the OpenAir package in R (Carslaw and Ropkins, 2012; Carslaw, 2015). Using PSCF, locations for the PMF-derived factors (sources) were estimated. PSCF calculates the relation of source-originated material in air mass trajectories passing through the location compared to all trajectories passing the same location. The method is described in Fleming et al. (2012) and Pekney et al. (2006). The 90th percentile was used for source concentrations in PSCF, which means that only the top $10 \%$ of source pollution containing trajectories were taken into account. In addition, NOAA's Hybrid Single-Particle Lagrangian Integrated Trajectory (HYSPLIT) model (Stein et al., 2015; Rolph et al., 2017) was utilized to interpret single peak values. The backward trajectories were calculated for $72 \mathrm{~h}$ with the global meteorological data from the Global Data Assimilation System (GDAS) archive with a 6-h time resolution (height $500 \mathrm{~m})$.

\subsection{Trend analysis}

Linear trends in the concentration time series were estimated using a Generalized Least Squares (GLS) regression with autoregressive moving average (ARMA) errors. In this statistical model, the autocorrelation typically present in an air pollution concentration time series is accounted for by iteratively applying an ARMA-based correlation structure to the residuals of the fitted linear model. GLS-ARMA analysis was performed on deseasonalized monthly averaged concentration time series. Details of the procedure are given in Anttila and Tuovinen (2010). The trends were calculated for two time periods: the full dataset of 23 years to study the overall changes and the last 9 years to examine more recent changes in the atmospheric concentrations of the studied elements.

The concentration time series were first visually inspected for non- 
linearities that could obviously not be explained in a satisfactory manner by the linear regression model. Some of the time series (e.g., Cu) had anomalously high values during the first months/years of the study period, and some had clear stepwise abrupt changes (Al, Fe, Mn) amidst the study period. In these cases, the linear model was fitted to the even part of the time series.

The trends for annual emissions were estimated using the nonparametric Mann-Kendall test (Gilbert, 1987; Salmi et al., 2002), which is applicable to the detection of a monotonic increasing or decreasing trend of a time series with no seasonal or other cycle. The trend was tested at significance levels of $\mathrm{P}<0.05, \mathrm{P}<0.01$ and $\mathrm{P}<0.001$ as a two-tailed test. Additionally, the nonparametric Sen's method was used to detect the magnitude of the trend as a slope of a linear trend, and the 95\% confidence interval for the slope estimator was calculated. For further details, see Salmi et al. (2002).

\section{Results and discussion}

\subsection{Changes in sampling and analysis}

Changes in sampling and analysis are sometimes inevitable in longterm measurements, and they may influence the concentration results of pollutants, thus complicating the statistical analysis of the time series. Regarding the change from total suspended particles (TSP) to the PM10 inlet, only a few available studies measure the significance of the size distribution to atmospheric heavy metal concentrations in background areas. One of them, a campaign study by Makkonen et al. (2010), studied the influence of different size cut-offs to the chemical composition of aerosols at the Southern Finnish background station, Virolahti. They found that more than half of the zinc, arsenic, lead, vanadium, cadmium and nickel were found in the submicron particles, and about $80-90 \%$ of all those elements were in particles $<2.5 \mu \mathrm{m}$. About $50 \%$ of copper was in the submicron particles and $63 \%$ in particles $<2.5 \mu \mathrm{m}$. In contrast, the soil elements iron and aluminum were mostly (about 60\%) in the coarse fraction $(2.5-10 \mu \mathrm{m})$, as was $48 \%$ of the manganese. In Greenland, Hillamo et al. (1993) found that trace elements were associated with $<$ PM10 fraction of particles, while many rural studies indicate that crustal elements can be found in particulates > PM10 (Pakkanen et al., 2001; Wang et al., 2016). In the winter season, when the soil is covered with snow at Pallas for several months (typically October/November to April/May), we do not expect to have much of particles larger than PM10. Thus, we estimate that the change in sampling may have had an impact on $\mathrm{Al}, \mathrm{Cr}, \mathrm{Fe}$ and $\mathrm{Mn}$ (during the summer season with no snow) but is unlikely to affect at least $\mathrm{As}, \mathrm{Cd}, \mathrm{Pb}$ and $\mathrm{Zn}$ in a site as remote as Pallas.

Changing the pretreatment method is another point of consideration in statistical analyses of time series. In particular, there are challenges in fully digesting the sample. In Jalkanen and Häsänen (1996), the recoveries of $\mathrm{HF} / \mathrm{HNO}_{3}$ cold extraction were very good for NIST SRM 1633b Coal Fly Ash (recovery 91-107\%, except for Al, 78\%), while for NIST 1648 Urban Particulate Matter, the recoveries were very good (80-98\%) except for $\mathrm{Cr}$, for which the recovery was as low as $28 \%$. Moreover, $\mathrm{Cr}$ digestion was found to be incomplete in a European Intercomparison Exercise for Heavy Metals in PM10 (Gerboles and Buzica, 2008) using, e.g., the EN 14902 method. Similarly, the recoveries of NIST 1648 a have been $82-102 \%$ for most elements in the FEI laboratory using the EN 14902 method, with the exceptions of $\mathrm{Al}$ (57\%) and $\mathrm{Cr}(72 \%)$. For these reasons, the time series are not only processed as a whole in this paper but are also partly divided into different periods, accounting for the changes described above.

\subsection{Atmospheric concentration levels}

The multiannual average concentrations for the heavy metals in PM during different time periods are shown in Table 1 . The time series was divided into five parts considering the changes to cut-off size in 2007 and to the pretreatment method in 2010. The measured PM10 concentrations of trace elements were rather low in general. In comparison to other background areas in Europe (within the EMEP network), Pallas has one of the lowest PM10 trace element concentrations. Typically, similar or slightly lower concentrations are observed only at the other northern stations Ny-Ålesund (NO), Andoya (NO), Bredkälen (SE) and Storhofdi (IS) (Aas and Nizzetto, 2014, 2015; Aas et al., 2016), while even lower concentrations have been observed in the high Arctic as recorded at the ASCOS Expedition in the Arctic Ocean in 2008 (Paatero et al., 2009). However, even in the arctic, north of our site, notably higher concentrations than at the Pallas site have been observed at sites close to industrial areas such as Karpdalen and Svanvik (NO). In 2018, the annual average Ni and Co concentrations in PM10 in Svanvik were about 30 times higher than at Pallas while $\mathrm{Cu}$ and As were 15 times higher, respectively (data obtained from Berglen et al., 2019). Comparing the 1996-2018 averages of As, Cd, Ni and $\mathrm{Pb}$ at Pallas to the respective EU limit and target values, the air concentrations were only $0.2-3.0 \%$ of the legislative limits.

Annual average concentrations for the priority elements (As, Cd, Ni and $\mathrm{Pb}$ ) at the Finnish background stations since 2007 are shown in Fig. 2. For other heavy metals, see supplementary material (Fig. A1). In the figures, time series from the Ähtäri (2007-2016) and Hyytiälä stations (2017-2018) are combined as they both present atmospheric concentrations in Central Finland. Comparing the results between sites, the south-to-north gradient is evident in the data with significantly higher PM10 trace element concentrations in the southernmost station than at the subarctic Pallas site. This is due to minor local emissions and longer distance to the large European source areas in the north than in the south. Additionally, the length of the snow-cover period has an effect on the re-suspension of some elements. A decreasing gradient from south to north was observed earlier in heavy metal deposition in Finland (Kyllönen et al., 2009), and similarly, a north-to-southeast increasing gradient has also been observed elsewhere in Europe (Aas et al., 2016).

Occasionally, the PM10 Ni and Cu concentrations in Pallas exceed the concentrations in Ähtäri and Hyytiälä, which are over $600 \mathrm{~km}$ south of Pallas. Although Pallas is far more remote from the European and national emission sources, emissions from the $\mathrm{Cu}-\mathrm{Ni}$ smelters in the Kola Peninsula sometimes attribute to the air concentrations at Pallas when the wind direction is from the east or northeast. In Fig. 3, an example of NOAA HYSPLIT backward trajectories are shown to verify the source areas for high $\mathrm{Cu}$ and $\mathrm{Ni}$ concentrations. As the PM10 filter samples were collected on a weekly time resolution, supplementary $\mathrm{SO}_{2}$ data measured hourly was utilized to identify the time of the week for elevated concentrations as a proxy. The trajectories indicate that the source areas were through Monchegorsk, the location of the largest $\mathrm{Cu}-\mathrm{Ni}$ smelter (Severonikel complex) in the Kola Peninsula (Paatero et al., 2008).

\subsection{Source apportionment}

PMF was utilized for two time series, 1996-2018 and 2014-2018. A five-factor solution was chosen to best represent the variations in the PM for both time series. In Fig. 4, the source apportionment of the trace elements combined with supplementary measurements is illustrated for the 1996-2018 period. For the 2014-2018 time series, a similar result was obtained; thus, it is not shown here. Source region maps are presented in Fig. 5. Altogether, five factors were identified: soil, marine, non-ferrous metal smelting, secondary LRT and LRT related to combustion. These factors contributed 33\%, 15\%, 5\%, 7\% and $40 \%$ of the PM10 mass, respectively. In 2018, PM10 was roughly estimated to compose of $47 \%$ water soluble inorganic ions, $42 \%$ particulate organic matter (POM), 4\% EC and $0.001 \%$ trace elements on average, however, the fractions change with season. These fractions were calculated by comparing the WSII sums, HM sums, OC multiplied by 2 to convert OC to POM (Turpin et al., 2000) and EC to the PM mass measured at a nearby site Sammaltunturi, thus the values are considered indicative only. The 
Table 1

The multiannual average concentrations and the standard deviations (in $\mathrm{ng} \mathrm{m}^{-3}$ ) of heavy metals in PM in different time periods at the Pallas site.

\begin{tabular}{|c|c|c|c|c|c|c|c|c|c|c|c|c|}
\hline Period & $\mathrm{Al}$ & As & $\mathrm{Cd}$ & Co & $\mathrm{Cr}$ & $\mathrm{Cu}$ & $\mathrm{Fe}$ & Mn & $\mathrm{Ni}$ & $\mathrm{Pb}$ & V & $\mathrm{Zn}$ \\
\hline \multirow[t]{2}{*}{ 1996-2000 } & 20.3 & 0.24 & 0.038 & 0.027 & 0.13 & 0.71 & 23.9 & 0.64 & 0.58 & 1.03 & 0.48 & 1.9 \\
\hline & \pm 4.9 & \pm 0.04 & \pm 0.009 & \pm 0.004 & \pm 0.05 & \pm 0.19 & \pm 3.6 & \pm 0.09 & \pm 0.14 & \pm 0.21 & \pm 0.10 & \pm 0.5 \\
\hline \multirow[t]{2}{*}{ 2001-2006 } & 21.8 & 0.20 & 0.038 & 0.027 & 0.15 & 0.48 & 28.1 & 0.71 & 0.46 & 1.06 & 0.48 & 2.5 \\
\hline & \pm 6.4 & \pm 0.10 & \pm 0.010 & \pm 0.005 & \pm 0.04 & \pm 0.11 & \pm 4.9 & \pm 0.12 & \pm 0.11 & \pm 0.32 & \pm 0.11 & \pm 0.5 \\
\hline \multirow[t]{2}{*}{ 2007-2009 } & 12.4 & 0.12 & 0.028 & 0.022 & 0.07 & 0.36 & 16.6 & 0.43 & 0.42 & 0.67 & 0.49 & 1.9 \\
\hline & \pm 0.5 & \pm 0.01 & \pm 0.002 & \pm 0.003 & \pm 0.01 & \pm 0.08 & \pm 2.1 & \pm 0.04 & \pm 0.10 & \pm 0.05 & \pm 0.08 & \pm 0.1 \\
\hline \multirow[t]{2}{*}{ 2010-2014 } & 12.0 & 0.15 & 0.024 & 0.020 & 0.14 & 0.37 & 15.0 & 0.42 & 0.32 & 0.69 & 0.32 & 1.9 \\
\hline & \pm 4.7 & \pm 0.04 & \pm 0.006 & \pm 0.003 & \pm 0.04 & \pm 0.08 & \pm 2.3 & \pm 0.07 & \pm 0.07 & \pm 0.20 & \pm 0.11 & \pm 0.4 \\
\hline \multirow[t]{2}{*}{ 2015-2018 } & 10.8 & 0.12 & 0.017 & 0.014 & 0.16 & 0.34 & 11.6 & 0.34 & 0.24 & 0.56 & 0.25 & 1.5 \\
\hline & \pm 3.1 & \pm 0.02 & \pm 0.002 & \pm 0.001 & \pm 0.04 & \pm 0.03 & \pm 2.7 & \pm 0.06 & \pm 0.05 & \pm 0.08 & \pm 0.01 & \pm 0.3 \\
\hline
\end{tabular}
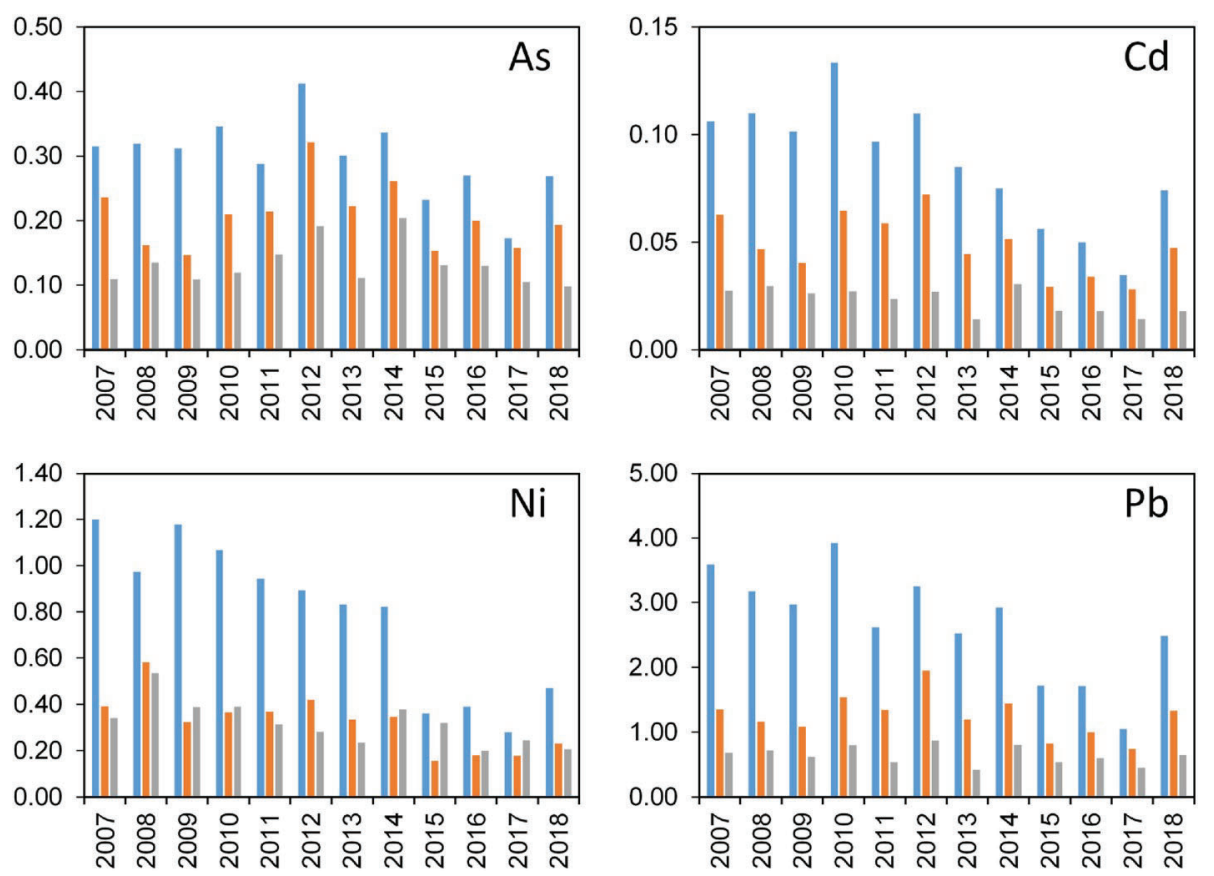

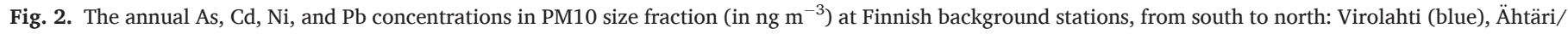
Hyytiälä (orange), and Pallas (gray). (For interpretation of the references to colour in this figure legend, the reader is referred to the Web version of this article.)

rest (estimated 11\%) is the unknown fraction of PM including the non-measured compounds, e.g. OC in the size fraction between PM2.5 and PM10 and oxygen combined to crustal elements.

In Factor 1, the main species were $\mathrm{Al}(83 \%), \mathrm{Fe}$ (57\%), $\mathrm{Mn}(47 \%)$ and Ca (39\%). These are known to be crustal components. Therefore, air masses containing soil components came from all directions with a slight emphasis on the south, and there were no specific source areas for this factor, as illustrated in the source region map. Approximately one-third of PM mass came in this factor. Interestingly, $29 \%$ of the organic carbon came into this factor (similar to the 2014-2018, run not shown here). As the cut-off size of OC was $2.5 \mu \mathrm{m}$, it was not measuring comprehensively soil-derived OC particles as the typical size of them are above $2.5 \mu \mathrm{m}$. The source of OC in this factor is quite likely biogenic secondary organic particles, which are formed from biogenic volatile organic carbon compounds (BVOC) (Tunved et al., 2006). This finding was supported by a factor time series with clear seasonality; the factor was peaking in the summer when VOC emissions are known to be highest (Hellén et al., 2018). This led to the conclusion that due to the similar seasonal variation, this PMF solution did not distinguish these two separate sources. In bootstrap runs, the main species, such as $\mathrm{Al}, \mathrm{Fe}, \mathrm{Mn}, \mathrm{Ca}$ and $\mathrm{OC}$, as well as PM sum, all went between the interquartile range (25-75\%), and their correlation between measured and modeled species were fairly good or good (between 0.4 and 0.8 for species other than OC). Uncertainty for modeled OC in this factor was high, and $\mathrm{r}^{2}$ was not satisfying.
This is probably due to the fact that there were OC measurements only from 2014 to 2018 and the rest of the modeled OC was synthetic data (median for OC time series) with manually elevated uncertainties. When running PMF with 2014-2018 data only, the correlation for OC between measured and modeled data was good $\left(r^{2}=0.4\right)$.

Factor 2 was a clear marine factor, as most $\mathrm{Cl}(96 \%), \mathrm{Na}(78 \%)$ and $\mathrm{Mg}(71 \%)$ came in this factor. The average molar ratio of $\mathrm{Na} / \mathrm{Cl}$ was 1.11 in this factor while that for sea is 0.86 indicating some $\mathrm{Cl}$ depletion in the marine air masses reaching our site. $\mathrm{Na} / \mathrm{Mg}$ molar ratio was 10.7. In another study in the south-eastern Finland background site (Anttila et al., 2008), molar ratios of 2.9 and 8.1 were calculated for $\mathrm{Na} / \mathrm{Cl}$ and $\mathrm{Na} / \mathrm{Mg}$ (converted from the reported mass ratios), however, the site is more affected by anthropogenic emissions than the Pallas site and was experiencing forest fire episode at the time. Fig. 4 shows the years 1996-2002 in gray, as that part of the time series did not include real measured $\mathrm{Cl}, \mathrm{Na}$ and $\mathrm{Mg}$ data and, thus, had a high uncertainty. This factor represents relatively clean marine airmasses arriving from the Arctic and North Atlantic Oceans. PSCF analysis supported this as the trajectories came from west. Moreover, $37 \%$ of TGM came in this marine factor, suggesting that the sea might be a significant source of gaseous mercury at Pallas. A previous PMF study from Virolahti, located on the Finnish southern coast of the Baltic Sea, also supports this finding, reporting that about $40 \%$ of TGM contributes to the sea salt factor (Vestenius et al., 2011). Cl, Na and Mg were between interquartile 


\section{NOAA HYSPLIT MODEL Backward trajectories ending at 0000 UTC 04 Mar 01 CDC1 Meteorological Data}

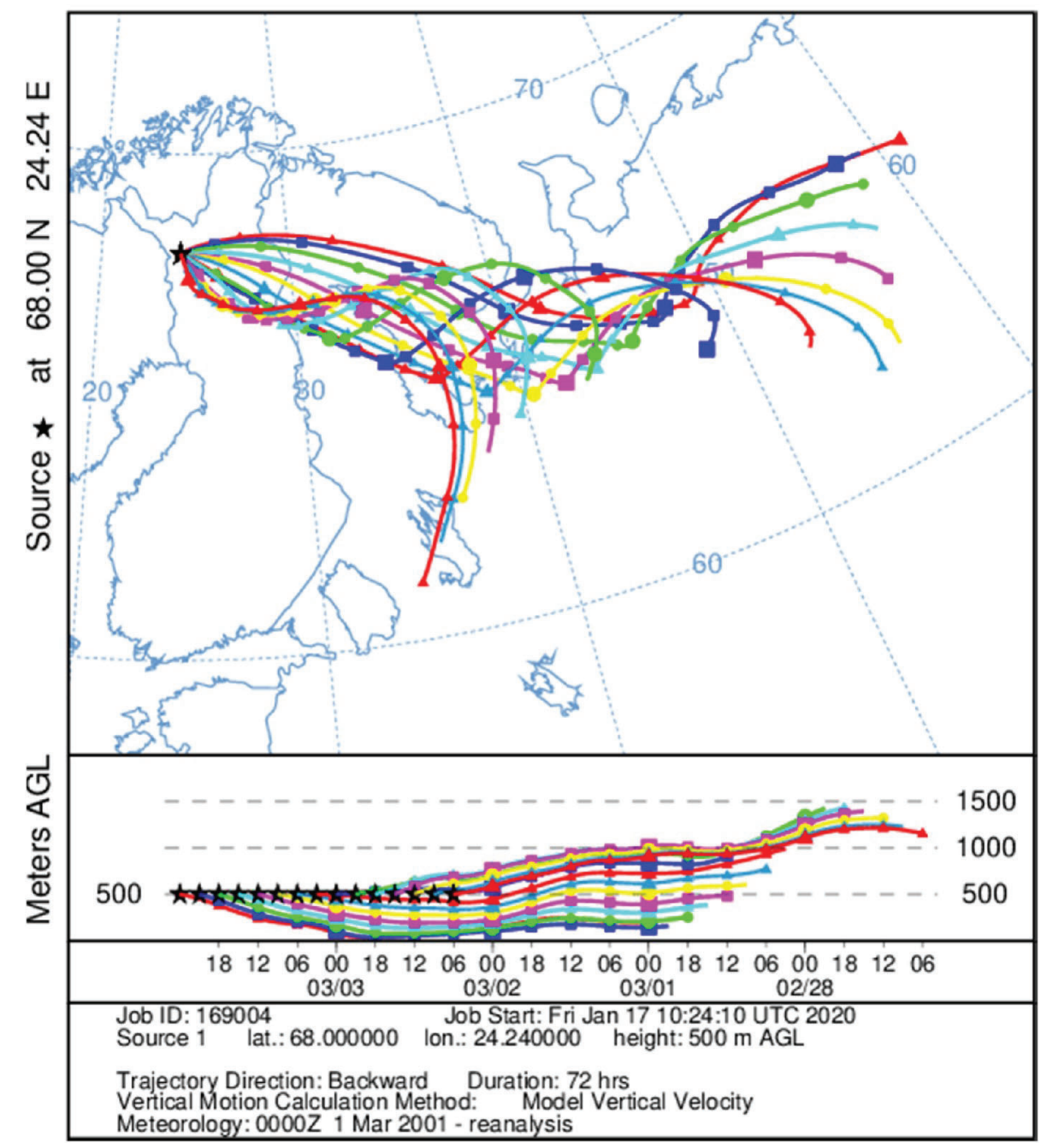

Fig. 3. NOAA HYSPLIT backward trajectories show the typical source region for high Ni and Cu concentrations at Pallas.

ranges in bootstrap runs. These were also modeled fairly well, $\left(\mathrm{r}^{2}=\right.$ 0.3-0.4). Unfortunately, for TGM, the modelling result is weaker, $\left(\mathrm{r}^{2}<\right.$ 0.3). However, in BS results, TGM just falls into the required acceptable interquartile range.

A high proportion of $\mathrm{Ni}(83 \%), \mathrm{Cu}(73 \%)$, Co (51\%) and As (50\%) was seen in Factor 3. Also, the main part of $\mathrm{SO}_{2}(82 \%)$ came in this factor with a smaller contribution of $\mathrm{SO}_{4}(23 \%)$, proposing a source close enough to still have the most sulphur as $\mathrm{SO}_{2}$ but sufficiently far enough that part of the $\mathrm{SO}_{2}$ had already oxidized into $\mathrm{SO}_{4}$. Source areas according to PSCF analysis referred to the east of Pallas. Considering the PSCF results, the elemental composition in the factor and the earlier literature (e.g., Paatero et al., 2008; Timonen et al., 2018; Virkkula et al., 1999), this factor was identified to represent the effect of Ni-Cu smelter emissions in the Kola Peninsula on the site. Thus, it was named the non-ferrous metal smelting. The decreasing time series of the factor indicates that emissions from the smelters may be lessening; this is considered an encouraging signal. All the main components of this factor were well modeled and also passed the bootstrap test.

In Factor 4, high contributions of $\mathrm{NH}_{4}$ sum (66\%), $\mathrm{NO}_{3}$ sum (49\%), $\mathrm{K}$ $(60 \%)$ and $\mathrm{SO}_{4}(36 \%)$ were found. This indicates an aged long-range transported pollution factor, where $\mathrm{SO}_{2}$ and $\mathrm{NO}_{\mathrm{x}}\left(\mathrm{NO}-\mathrm{NO}_{2}\right)$ had been neutralized by, e.g., $\mathrm{NH}_{3}$ to form $\mathrm{SO}_{4}$ and $\mathrm{NO}_{3}$. Additionally, the main part of OC (71\%), TGM (52\%) and K (60\%) were found in this factor. With the lifetime in the order of $0.5-2$ years (Schroeder and Munthe, 1998; Selin, 2009), TGM is typically attributed to LRT (Durnford et al., 2010), while in the Arctic, OC can be attributed to LRT among other sources (von Schneidemesser et al., 2009; Timonen et al., 2018). K is often used as a tracer for biomass burning despite having several other sources related to, e.g., LRT (Pachon et al., 2013). This factor may contain traces of biomass burning but most likely they are long-range transported. As the site was remote, the local sources of biomass burning emissions were sparse. It is noteworthy that no EC was seen in this factor. Due to the long distance to the biomass burning sources, EC has likely diluted along with the distance. The PSCF analysis suggested sources in the south, both national and mainly further in the Baltic and Poland. $\mathrm{NH}_{4}$ and $\mathrm{NO}_{3}$ sums and $\mathrm{SO}_{4}$ were well modeled, with $\mathrm{r}^{2}$ being between 0.6 and $0.8 \mathrm{~K}$ is more difficult to model, as is TGM. However, all these passed the bootstrap test in this factor, so the result is within acceptable limits.

Factor 5 included $70 \%$ of $\mathrm{Pb}, 66 \%$ of $\mathrm{Zn}, 59 \%$ of $\mathrm{Cd}, 38 \%$ of $\mathrm{Cr}$ and $34 \%$ of As, as well as $84 \%$ of EC. This factor included most of the PM10 mass $(40 \%)$. These elements are typically originating from primary emissions related to combustion and energy production. The fraction of $\mathrm{OC}$ in this factor was negligible. The high contributions of aged (F4) and 


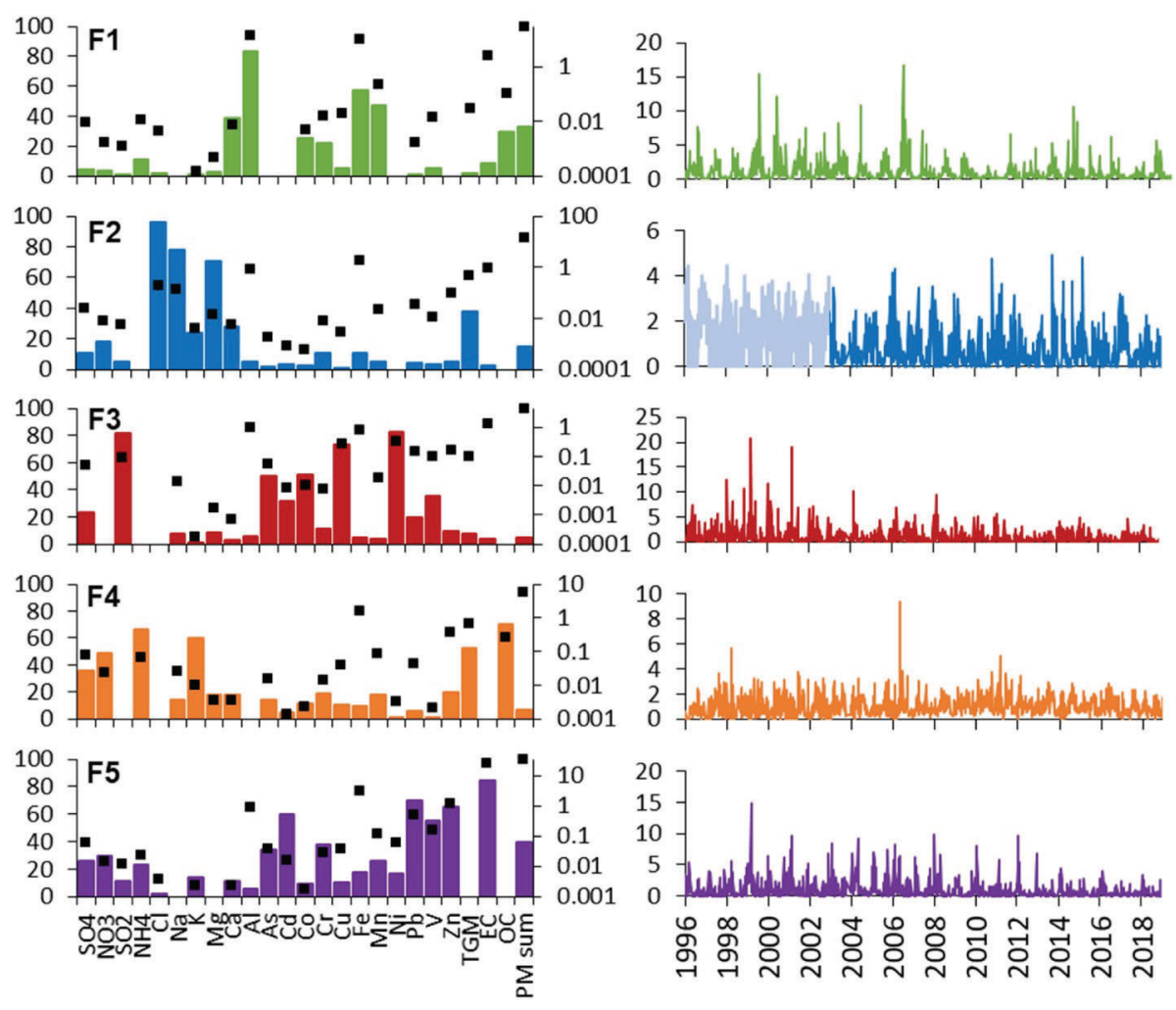

Fig. 4. On the left, the PMF source contribution as coloured bars (\%) and absolute contents as black squares (trace elements, TGM and EC in ng $\mathrm{m}^{-3}$, and WSIIs, OC, PM sum and SO2 in $\mu \mathrm{g} \mathrm{m}^{-3}$, note logarithmic scale). On the right, profile time series for the Pallas 1996-2018 run. In the profile time series, the units are arbitrary, so comparison between factors is not relevant.

biogenic OC (F1) likely drown the other sources of OC. Furthermore, the contribution of OC from fossil fuel has been presented to be only $6 \%$ of total carbon in summertime at rural background sites (Yttri et al., 2011). Nationally, $70-90 \%$ of the anthropogenic emissions of these elements are from energy production (FEI, 2020). In Europe, emissions reported for $\mathrm{As}, \mathrm{Cd}$ and $\mathrm{Pb}$ are mainly from energy production, distribution and industrial use (EEA, 2019a), while for black carbon (BC, which is closely equivalent to EC), there are several reported sources, including commercial, institutional and household (48\%), road transport (28\%) and energy (12\%) according to the EEA (2019b). However, many studies emphasize the high portion of fossil fuel combustion and biomass burning as an EC source for the Arctic (Bond et al., 2004; Hyvärinen et al., 2011; Sharma et al., 2013; Winiger et al., 2016). For PM mass, $40 \%$ was seen in this factor. Like our results, Nguyen et al. (2013) reported a combustion source for Greenland having high loadings of $\mathrm{As}, \mathrm{Pb}$ and EC. Our PSCF analysis referred to areas in South Finland and Western Russia, which is home to the metropolis of St. Petersburg with its five million inhabitants. This is similar to Hyvärinen et al. (2011), in which BC was found to mostly originate from Central and Eastern Europe while moderate source areas were located in Southern Finland. All the main components in this factor, including EC, passed the bootstrap test. All but EC modeled well not only in the long time series but also in the short time series of 2014-2018, in which also EC modeled well.

Altogether, bootstrap mapping for base results were within acceptable limits, being 100\% for all factors except for F2 (Marine), in which bootstrap mapping was 95\%. See supporting documents, Table A3.

\subsection{Trend analysis}

In Table 2, the trends are presented for two time periods: (1) the whole time series of 1996-2018 to examine long-term trends and (2) 2010-2018 to study recent changes during a time with no changes in the sampling and analysis methods. The respective time series of the trends are given in Fig. 6, Fig. A2 and Fig. A3.

For $\mathrm{Al}, \mathrm{Cr}, \mathrm{Fe}$ and $\mathrm{Mn}$, trend analysis results for the whole time series are not presented here due to the changes in cut-off size (in 2007) since the changes have clearly influenced the concentration level (see Fig. 6 and A2). For $\mathrm{Cu}$, the trend is reported for 2000-2018 instead of 1996-2018 as, in this case, the decrease in concentrations in the early years of measurements would have determined the overall trend (Fig. 6), and it remains unsolved if the higher concentration level in 1996-1999 resulted from actual concentrations or measurement biases. For Ni, similar behavior can be observed to a lesser extent; thus, the trend was evaluated for the whole time series (see Fig. A2).

For atmospheric concentrations, a statistically significant decreasing trend is observed for the long time series for most elements (Table 2). For the 2010s, the positive development continues with statistically significant decreasing trends for half of the studied elements, and the rest show a tendency to decline. The only exception is aluminum, which indicates a slight increase in 2010-2018 (not statistically significant).

For $\mathrm{As}, \mathrm{Co}, \mathrm{Cu}$ and $\mathrm{Ni}$, which are mostly attributed to emissions from the Kola Peninsula (see Section 3.3 for source apportionment results), the decline in air concentration has been statistically significant during the 1996-2018 period (as is also evident in the Factor 3 time series in Fig. 4). This is also true for the national anthropogenic emissions (Table 3). During the last nine years, only Ni and Co in PM10 continue the statistically significant decrease by $44 \%$ and $41 \%$, respectively. All these components show a seasonal cycle with winter maxima and autumn minima. This phenomenon indicates that the station is also affected by seasonal sources, likely soil resuspension and LRT from national and Central European areas, as the industrial emissions from the Kola Peninsula are not expected to have much annual variation. However, also meteorology and pollutant transport characteristics are seasonally driven and may be partly behind the observed seasonal cycle of the elements. PMF results also indicate a long-range transported 

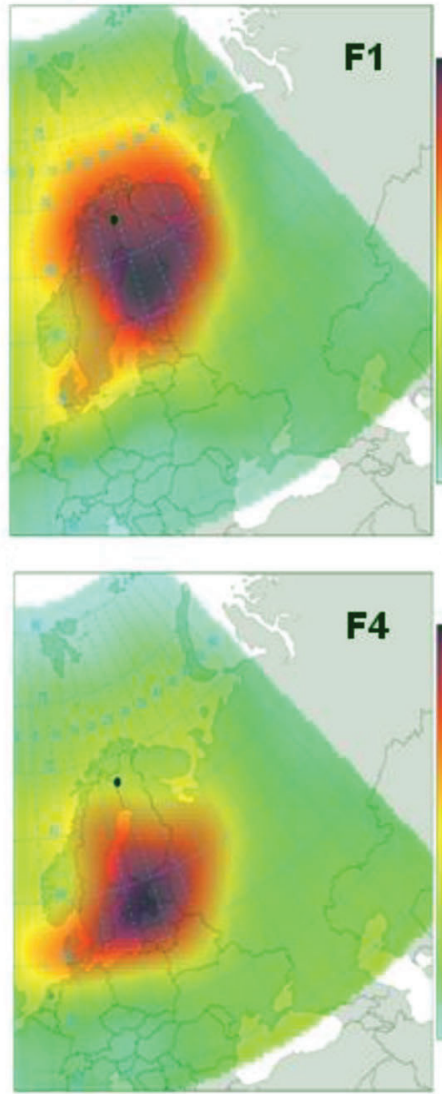
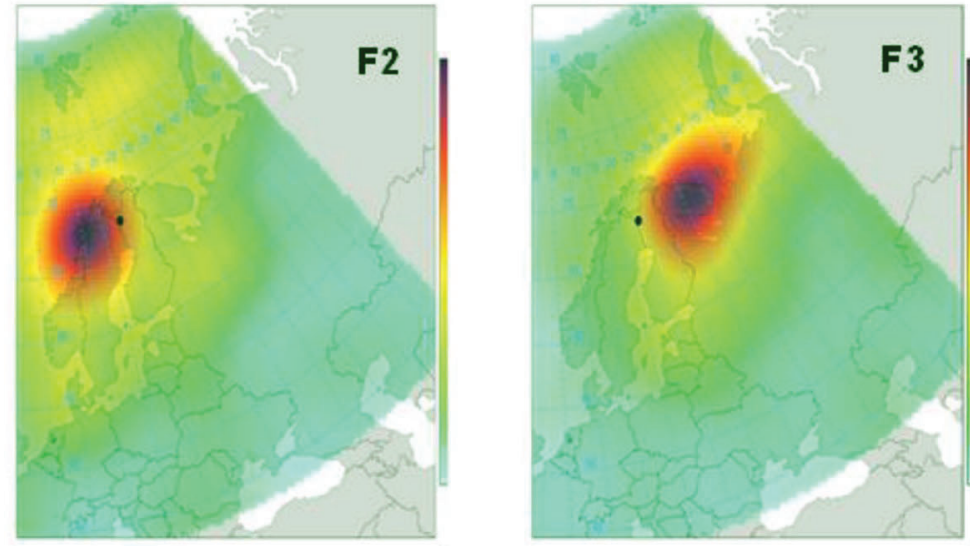

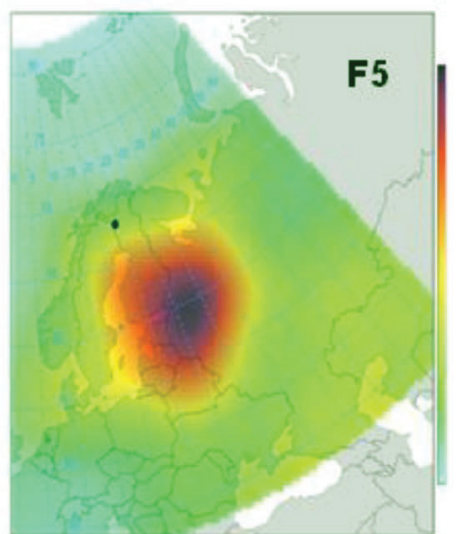

Fig. 5. Source region maps of the PMF factors F1-F5: soil, marine, non-ferrous metal smelting, secondary LRT and combustion LRT. Pallas is denoted as a black dot. The scales of the PSCF probability differ.

Table 2

Results of the trend analysis for monthly averaged HM PM10 concentrations. Intercept and slope are presented in ng $\mathrm{m}^{-3}$ and ng $\mathrm{m}^{-3}$ month ${ }^{-1}$, respectively, and standard errors are given in parentheses. Annual changes in $\%$ are shown with their $\pm 95 \%$ confidence limits. Statistically significant $(\mathrm{P}<0.05)$ trends are shown in bold text $(\mathrm{P}<0.001$, ***; $\mathrm{P}<0.01, * * ; \mathrm{P}<0.05$, *).

\begin{tabular}{|c|c|c|c|c|c|c|c|c|}
\hline \multirow[t]{3}{*}{ Component } & \multicolumn{2}{|l|}{ 1996-2018 } & \multirow[b]{2}{*}{ Change } & & \multicolumn{2}{|l|}{ 2010-2018 } & \multirow[b]{2}{*}{ Change } & \multirow[b]{3}{*}{ Significance } \\
\hline & Intercept & Slope & & & Intercept & Slope & & \\
\hline & $\mathrm{ng} \mathrm{m}^{-3}$ & $\mathrm{ng} \mathrm{m}{ }^{-3}$ month $^{-1}$ & $\%$ year $^{-1}$ & Significance & $\mathrm{ng} \mathrm{m}^{-3}$ & $\mathrm{ng} \mathrm{m} \mathrm{m}^{-3}$ month $^{-1}$ & $\%$ year $^{-1}$ & \\
\hline $\mathrm{Al}$ & - & - & - & - & $9.89(2.53)$ & $0.0295(0.0398)$ & $3.6 \pm 9.5$ & - \\
\hline As & $0.25(0.02)$ & $-0.0005(0.0001)$ & $-2.6 \pm 1.2$ & $* * *$ & $0.16(0.02)$ & $-0.0004(0.0003)$ & $-3.1 \pm 4.1$ & - \\
\hline Cd & $0.04(0.003)$ & $-0.0001(0.00002)$ & $-2.6 \pm 1.1$ & $* * *$ & $0.03(0.003)$ & $-0.0001(0.00004)$ & $-4.6 \pm 3.8$ & $*$ \\
\hline Co & $0.03(0.002)$ & $-0.0001(0.00001)$ & $-2.2 \pm 0.7$ & $* * *$ & $0.02(0.002)$ & $-0.0001(0.00003)$ & $-4.6 \pm 3.0$ & $* *$ \\
\hline $\mathrm{Cr}$ & - & - & - & - & $0.11(0.02)$ & $0.0007(0.0004)$ & $7.3 \pm 7.6$ & - \\
\hline $\mathrm{Cu}^{*}$ & $0.48(0.04)$ & $-0.0007(0.0003)$ & $-1.8 \pm 1.3$ & $* *$ & $0.37(0.03)$ & $-0.0002(0.0005)$ & $-0.7 \pm 3.1$ & - \\
\hline $\mathrm{Fe}$ & - & - & - & - & 15.04 (1.77) & $-0.0260(0.0279)$ & $-2.1 \pm 4.4$ & - \\
\hline Mn & - & - & - & - & $0.43(0.03)$ & $-0.0009(0.0006)$ & $-2.4 \pm 3.0$ & - \\
\hline $\mathrm{Ni}$ & $0.60(0.04)$ & $-0.0014(0.0003)$ & $-2.8 \pm 1.0$ & $* * *$ & $0.37(0.04)$ & $-0.0015(0.0006)$ & $-4.9 \pm 3.7$ & $*$ \\
\hline $\mathbf{P b}$ & $1.13(0.09)$ & $-0.0022(0.0005)$ & $-2.3 \pm 1.1$ & $* * *$ & $0.71(0.02)$ & $-0.0016(0.0004)$ & $-2.8 \pm 1.3$ & $* * *$ \\
\hline V & $0.55(0.04)$ & $-0.0011(0.0002)$ & $-2.3 \pm 1.0$ & $* * *$ & $0.40(0.05)$ & $-0.0019(0.0007)$ & $-5.9 \pm 4.3$ & $* *$ \\
\hline $\mathrm{Zn}$ & $2.24(0.17)$ & $-0.0019(0.0011)$ & $-1.0 \pm 1.1$ & - & $2.04(0.13)$ & $-0.0063(0.0021)$ & $-3.7 \pm 2.4$ & $* *$ \\
\hline
\end{tabular}

*For $\mathrm{Cu}$, the trend is given for 2000-2018 instead of 1996-2018.

source for these elements with a seasonal cycle in Fig. 4 (Factor 5) together with the crustal factor (F1). Kashulina et al. (2014) report a five-to sixfold decrease in $\mathrm{Ni}$ and $\mathrm{Cu}$ rain water concentrations close to the Severonikel industrial complex between 1994 and 2011, and they present a major emission decrease in the same period (as reported by htt p://www.kolagmk.ru, website in Russian); however, the authors stress that pollution is still extremely high with these concentrations. Reliable emission data from the Pechenganikel combine (Nikel and Zapoljarniy) and Severonikel complex (Monchegorsk) is not freely available, but the trend and source apportionment analysis indicate that these emissions have decreased during the last twenty years, but the positive development may be leveling off during this decade.

Other metals of anthropogenic origin, mainly $\mathrm{Cd}, \mathrm{Pb}, \mathrm{V}$ and $\mathrm{Zn}$, have multiple sources, and thus, differing changes are observed. $\mathrm{Cd}, \mathrm{Pb}$ and $\mathrm{V}$ have declined by $60 \%, 53 \%$ and 53\% ( $\mathrm{P}<0.001$ ), respectively, in 1996-2018. However, a statistically significant change is not observed for $\mathrm{Zn}$ in that period, while during this decade, all four elements have statistically significant decreasing trends.

With $\mathrm{Pb}$, major decreases were observed in the 1980s-1990s due to the changes in regulation for the use of $\mathrm{Pb}$ as a gasoline additive in 

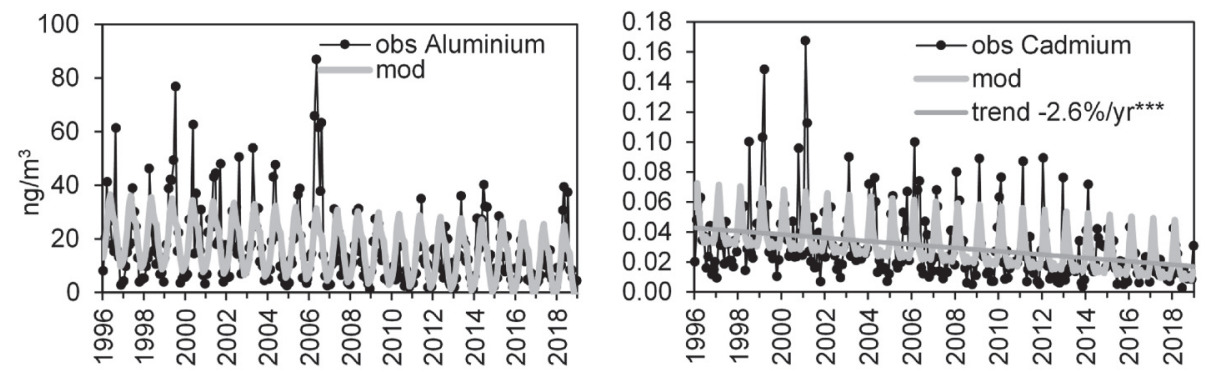

Fig. 6. Monthly mean $\mathrm{Al}, \mathrm{Cd}, \mathrm{Pb}$ and $\mathrm{Cu}$ concentrations at Pallas in 1996-2018. The black lines (obs) indicate the measured concentrations, while the gray lines (mod and trend) present the seasonal component combined with the GLS-ARMA estimated trend. The $\mathrm{Al}$ trend is not reported, as the introduction of PM10 sample inlet in 2007 affected the measured concentrations. The $\mathrm{Cu}$ trend was calculated for 2000-2018, as the first years with higher concentrations would determine the overall trend.
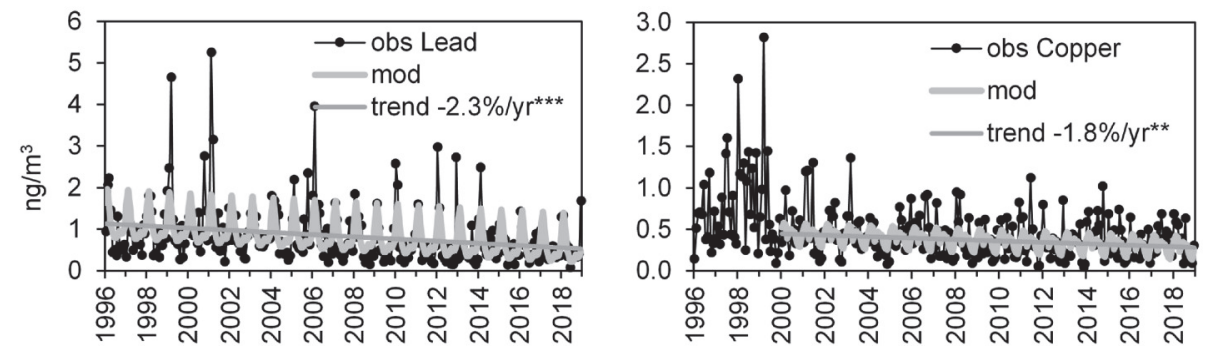

\section{Table 3}

Results of the trend analysis for national heavy metal emissions in 1996-2017 and 2008-2017. Annual changes in \% are shown. Only statistically significant $(\mathrm{P}<0.05)$ trends are shown.

\begin{tabular}{lll}
\hline Component & $1996-2017$ & $2008-2017$ \\
\hline $\mathrm{As}$ & -2.8 & -2.2 \\
$\mathrm{Cd}$ & -2.1 & -3.2 \\
$\mathrm{Cr}$ & -2.2 & - \\
$\mathrm{Cu}$ & -2.6 & - \\
$\mathrm{Ni}$ & -3.0 & -3.4 \\
$\mathrm{~Pb}$ & -2.9 & -2.2 \\
$\mathrm{Zn}$ & -0.8 & - \\
\hline
\end{tabular}

Europe. Also, The Aarhus Treaty, signed in 1998 by all Western and nearly all Eastern European countries, stipulated the exclusive usage of unleaded gasoline in Europe by 2005 (von Storch et al., 2003). These regulations have had a major positive impact on atmospheric $\mathrm{Pb}$ concentration. According to our results, the decrease in atmospheric concentration continues in this decade, although somewhat more moderately.

$\mathrm{Cd}$ has a steady declining trend over the time series $\left(0.001 \mathrm{ng} \mathrm{m}^{-3}\right.$ year $^{-1}$ ). The PMF results indicate that over $90 \%$ of Cd comes from the long-range transported (LRT) anthropogenic sources (F3-F5). Vanadium has a similarly steady declining time trend and corresponding source profile as Cd. Energy production is the highest national source of these elements, being $68 \%$ for Cd and $90 \%$ for V (FEI, 2020). V is mostly assigned to combustion activities involving heavy petroleum products, while for $\mathrm{Cd}$, both combustion of fuels and industry are main sources (Pacyna et al., 2001; Pacyna et al., 2009; Moreno et al., 2010; Schlesinger et al., 2017). Cd emissions have been strongly reduced since 1996, both nationally and in the neighboring countries, as well as in Europe (EEA, 2019; Gusev, 2018). The reduction of emissions has also continued since 2010 in Finland and Europe, but the trend is leveling off in most countries. Data on emissions and atmospheric trends for V are scarce, but, e.g., Harmens et al. (2015) reported that the declining trend of V deposition in Europe has been stabilizing since 2005, while the clear declining trend of $\mathrm{V}$ is still seen after 2005 in the Netherlands (Visschedijk et al., 2013).

According to the PMF results, Zn originated almost solely from longrange transport. It behaved differently from the other elements: although the other elements associated with anthropogenic origin have experienced a decrease in ambient concentrations, no change was observed for Zn during the 23-year time series. During that same time, national emissions have decreased by $17 \%$ (FEI, 2020), while European emissions lessened by 25\% in 1995-2017 (EEA, 2019). Contradictorily, the national and European emissions indicate no change during 2008-2017, while atmospheric concentrations decreased at Pallas in 2010-2018 with a 3.7\% annual rate. However, this decrease is mostly associated with the reduction of peak concentrations. It is possible that the rather moderate national and European change in emissions since the mid-1990s (compared to many other pollutants with large reductions) does not have a clear effect on atmospheric concentrations at this remote location far away from the sources, and the reason for the decrease in PM remains unexplained.

When calculating the change of element concentrations with origins mostly from the soil (Al, Fe, Mn) in 1996-2018, a statistically significant and similar decrease is seen. However, the change of sampling from TSP to PM10 has obviously influenced the measured air concentrations, and thus, the calculated trends are not relevant, and the data are not shown here. Since 2010, no statistically significant trends are observed for these elements.

In addition to changes in PM10 concentrations, another characteristic of these time series is the strong seasonality. In the GLS-ARMA procedure, the seasonal variation is captured by applying a moving average filter to the monthly time series and calculating the monthly indexes from these (see Anttila and Tuovinen, 2010; Anttila et al., 2016). This is demonstrated for selected elements in Fig. 6, where the original monthly time series is combined with the time series obtained with the GLS-ARMA method. For the other elements, the reader is referred to the supplementary material (Fig. A2). For soil-derived elements (Al, Fe, $\mathrm{Mn}$ ), the lowest concentrations are observed in the winter, when the snow covers the ground, and are highest in spring after the snowmelt. For elements associated with energy production (e.g., $\mathrm{Cd}$ and $\mathrm{Pb}$ ), the highest concentrations are observed during the heating season in winter. For $\mathrm{Cu}$, the seasonality is not that strong, which supports the earlier assumption for industrial and other sources of $\mathrm{Cu}$. The original monthly time series for all elements combined with the time series obtained with the GLS-ARMA procedure for the 2010-2018 period can be found in the supplementary material (Figs. A3a and A3b).

To further validate the measured trends, annual emissions for As, Cd, $\mathrm{Cr}, \mathrm{Cu}, \mathrm{Ni}, \mathrm{Pb}$ and $\mathrm{Zn}$ in Finland as reported by the Finnish Environment Institute (FEI, 2020) were studied. The trends for emissions were calculated with the Mann-Kendall and Sen's slope method for the annual values and are shown in Table 3 for two time periods similar to the PM10 concentration time series (year 2018 not available). The time series of emissions are given in the supplementary material (Fig. A4). 
Regarding national emissions, all reported elements have statistically significant decreasing trends during the study periods. For As and $\mathrm{Pb}$, the major reduction occurred in the 1990s, and during the last ten years, the emissions continued to decrease (Fig. A4). In addition, $\mathrm{Cu}, \mathrm{Zn}$ and $\mathrm{Cr}$ emissions experienced a clear reduction in the 1990s, while during the last 10 years, the emissions have settled to a rather constant level. Ni and Cd emissions seem to decrease steadily. These results supported the trend analysis of atmospheric concentrations.

\section{Conclusions}

During the last 23 years, a number of heavy metals in particulate matter have been monitored at the subarctic Pallas station in Finland. In general, the concentrations are among the lowest measured in the Northern Hemisphere. However, the effect of long-range transported pollution, e.g. the heavy industry in the Kola Peninsula, is detectable in the results. This was also confirmed in the PMF analysis, for which five separate factors were identified: soil, marine, non-ferrous metal smelting, secondary LRT and LRT related to combustion. Of these elements, $\mathrm{Al}, \mathrm{Fe}$ and $\mathrm{Mn}$ were mostly associated with the soil factor, while gaseous $\mathrm{Hg}$ was divided between the LRT and marine factors. $\mathrm{Cd}, \mathrm{Pb}, \mathrm{V}$ and $\mathrm{Zn}$ were mostly associated with the LRT combustion factor. Most of the Ni, $\mathrm{Cu}$, As and Co was associated with the Kola industry. Cr was the most divided element, with fractions of $10-40 \%$ in all factors; this result is most likely affected by the high measurement uncertainty associated with, e.g., low recoveries during sample pretreatment. In this study, LRT related to combustion and soil were found to be the main sources contributing to the PM mass at Pallas.

During 1996-2018, statistically significant decreasing trends up to $64 \%$ were observed for all elements of anthropogenic origin except for $\mathrm{Cr}$ and $\mathrm{Zn}$. As the concentrations are very low at this remote site, the annual decline has only been between $0.0007 \mathrm{ng} \mathrm{m}^{-3}$ (lowest for Co) and $0.026 \mathrm{ng} \mathrm{m}^{-3}$ (highest for $\mathrm{Pb}$ ), resulting in absolute changes between $0.02 \mathrm{ng} \mathrm{m}^{-3}(\mathrm{Co})$ and $0.60 \mathrm{ng} \mathrm{m}^{-3}(\mathrm{~Pb})$ during the whole time series. In the current decade, atmospheric concentrations continued to lessen for half of the studied elements, namely $\mathrm{Cd}, \mathrm{Co}, \mathrm{Ni}, \mathrm{Pb}, \mathrm{V}$ and $\mathrm{Zn}$, with changes between $25 \%$ and $53 \%$ in the period. For soil-derived elements ( $\mathrm{Al}, \mathrm{Fe}, \mathrm{Mn}$ ), changes in the sampling affected the results, and thus, only trends for the 2010-2018 period were considered in the article; however, no statistically significant change was observed in that period.

Monitoring atmospheric pollutants in a remote site for decades offers a productive tool to study long-term changes in the environment. Longterm measurements also assess the impact of international policies related to atmospheric pollutants. This study proves that emission reductions have decreased atmospheric concentrations at least in the studied area. However, the positive change seems to be leveling off in the recent decade for several heavy metals in PM10 measured at the site.

\section{Declaration of competing interest}

The authors declare that they have no known competing financial interests or personal relationships that could have appeared to influence the work reported in this paper.

\section{CRediT authorship contribution statement}

Katriina Kyllönen: Conceptualization, Validation, Investigation, Formal analysis, Resources, Writing - original draft, Writing - review \& editing, Visualization. Mika Vestenius: Formal analysis, Writing - review \& editing, Visualization. Pia Anttila: Formal analysis, Writing review \& editing, Visualization. Ulla Makkonen: Validation, Investigation, Resources, Writing - review \& editing. Minna Aurela: Validation, Investigation, Resources, Writing - review \& editing. Ingvar Wängberg: Validation, Investigation, Resources, Writing - review \& editing. Michelle Nerentorp Mastromonaco: Resources, Writing - review \& editing. Hannele Hakola: Conceptualization, Resources, Writing - review \& editing, Supervision, Project administration, Funding acquisition.

\section{Acknowledgments}

This work was supported by the Academy of Finland Centre of Excellence programme (grant no. 307331).

The authors would like to thank the numerous station keepers, technicians and laboratory personnel for their valuable work in running the measurements since the 1990s.

\section{Appendix A. Supplementary data}

Supplementary data to this article can be found online at https://doi. org/10.1016/j.atmosenv.2020.117644.

\section{Data availability}

Datasets related to this article can be found at http://ebas.nilu.no, the EBAS database infrastructure operated by NILU, and https://www. eea.europa.eu/data-and-maps/data/aqereporting-8\#tab-figures -produced, the AIRBASE database infrastructure operated by EEA.

\section{References}

Aas, W., Nizzetto, P.B., 2014. Heavy Metals and POP Measurements, 2012, p. 162. EMEP/CCC-Report 4/2014.

Aas, W., Nizzetto, P.B., 2015. Heavy Metals and POP Measurements, 2013, p. 147. EMEP/CCC-Report 3/2015.

Aas, W., Nizzetto, P.B., Pfaffhuber, K., 2016. Heavy Metals and POP Measurements, 2014, p. 150. EMEP/CCC-Report 4/2016.

AMAP, 2005. AMAP Assessment 2002: Heavy Metals in the Arctic. Arctic Monitoring and Assessment Programme (AMAP), Oslo, Norway. Xvi + 265, ISBN 82-7971-018-3 (first published as electronic document in 2004).

Anttila, P., Brorström-Lunden, E., Hansson, K., Hakola, H., Vestenius, M., 2016. Assessment of the spatial and temporal distribution of persistent organic pollutants (POPs) in the Nordic atmosphere. Atmos. Environ. 140, 22-33.

Anttila, P., Tuovinen, J.-P., 2010. Trends of primary and secondary pollutant concentrations in Finland in 1994-2007. Atmos. Environ. 44, 30-41.

Anttila, P., Makkonen, U., Hellén, H., Kyllönen, K., Leppänen, S., Saari, H., Hakola, H., 2008. Impact of the open biomass fires in spring and summer of 2006 on the chemical composition of background air in south-eastern Finland. Atmos. Environ. 42, 6472-6486.

Bauer, J.J., Yu, X.-Y., Cary, R., Laulainen, N., Berkowitz, C., 2009. Characterization of the sunset semi-continuous carbon aerosol analyzer. J. Air Waste Manag. Assoc. 59 (7), 826-833. https://doi.org/10.3155/1047-3289.59.7.826.

Berglen, T.F., Nilsen, A.C., Våler, R.L., Vadset, M., Uggerud, H.T., Andresen, E., 2019. Grenseområdene Norge-Russland. Luft-Og Nedbørkvalitet, Årsrapport 2018. NILU Rapport 15/2019, p. 75 (in Norwegian), Kjeller, Norway.

Bond, T.C., Streets, D.G., Yarber, K.F., Nelson, S.M., Woo, J.-H., Klimont, Z., 2004. A technology-based global inventory of black and organic carbon emissions from combustion. J. Geophys. Res. 109, D14203.

Carslaw, D.C., Ropkins, K., 2012. Openair — an R package for air quality data analysis. Environ. Model. Software 27-28, 52-61.

Carslaw, D.C., 2015. The Openair Manual — Open-Source Tools for Analysing Air Pollution Data. Manual for Version 1.1-4(. , King's College London).

Cavalli, F., Viana, M., Yttri, K.E., Genberg, J., Putaud, J.-P., 2010. Toward a standardised thermal-optical protocol for measuring atmospheric organic and elemental carbon: the EUSAAR protocol. Atmos. Meas. Tech. 3, 79-89.

Durnford, D., Dastoor, A., Figueras-Nieto, D., Ryjkov, A., 2010. Long range transport of mercury to the Arctic and across Canada. Atmos. Chem. Phys. 10, 6063-6086.

EEA, 2019a. European Union Emission Inventory Report 1990-2017 under the UNECE Convention on Long-Range Transboundary Air Pollution (LRTAP). EEA Report No 08/2019, ISBN 978-92-9480-078-7. https://doi.org/10.2800/7822. ISSN $1977-8449$.

EEA, 2019b. Air Quality in Europe - 2019 Report. EEA Report No 10/2019. European Environment Agency, Luxembourg, ISBN 978-92-9480-088-6, p. 104. ISSN 19778449.

EEA, 2020. Heavy Metal Emissions. European Environment Agency. https://www.eea.eu ropa.eu/data-and-maps/indicators/eea32-heavy-metal-hm-emissions-1/assessme nt-10 (Jan, 2020).

EU, 1999. Council Directive 1999/30/EC of 22 April 1999 relating to limit values for sulphur dioxide, nitrogen dioxide and oxides of nitrogen, particulate matter and lead in ambient air. Off J 1999, L 163, 41-60. EN:HTML (Jan, 2020). http://eur-lex.eur opa.eu/LexUriServ/LexUriServ.do?uri=CELEX:31999L0030.

EU, 2004. Directive 2004/107/EC of the European Parliament and of the Council of 15 December 2004 relating to arsenic, cadmium, mercury, nickel and polycyclic 
aromatic hydrocarbons in ambient air. Off J 2005, L 23, 3-16. EN:PDF (Jan, 2020). http://eur-lex.europa.eu/LexUriServ/LexUriServ.do?uri=OJ:L:2005:023:0003: 0016.

EU, 2008. Directive 2008/50/EC of the European Parliament and of the Council of 21 May 2008 on ambient air quality and cleaner air for Europe. Off J 2008, L 152, 1-44. http://eur-lex.europa.eu/legal-content/EN/TXT/PDF/?uri=CELEX:32008L0050\&fr $\mathrm{om}=\mathrm{EN}$. (Accessed January 2020).

EU, 2015. Commission Directive (EU) 2015/1480 of 28 August 2015 amending several annexes to Directives 2004/107/EC and 2008/50/EC of the European Parliament and of the Council laying down the rules concerning reference methods, data validation and location of sampling points for the assessment of ambient air quality. Off J 2015, L 226, 4-11. https://eur-lex.europa.eu/eli/dir/2015/1480/oj. (Accessed January 2020)

FEI, 2020. Air pollutant emissions in Finland until 2017. http://www.ymparisto.fi/ en-US/Maps and statistics/Air_pollutant emissions (Jan, 2020).

Fleming, Z.L., Monks, P.S., Manning, A.J., 2012. Review: untangling the influence of airmass history in interpreting observed atmospheric composition. Atmos. Res. 104-105, 1-39. https://doi.org/10.1016/j.atmosres.2011.09.009.

Gerboles, M., Buzica, D., 2008. Intercomparison Exercise for Heavy Metals in PM10. EUR 23219 EN. Office for Official Publications of the European Communities, Luxembourg. https://doi.org/10.1002/leap/30023.

Gilbert, R.O., 1987. Statistical Methods for Environmental Pollution Monitoring. Van Norstrand Reinhold, New York, p. 320.

Gusev, A., 2018. Atmospheric emissions of heavy metals in the Baltic Sea region. HELCOM Baltic Sea environment fact sheets. http://www.helcom.fi/baltic-sea-tr ends/environment-fact-sheets/. (Accessed 8 October 2019).

Harmens, H., Norris, D.A., Sharps, K., Mills, G., Alber, R., Aleksiayenak, Y., Blum, O., Cucu-Man, S.M., Dam, M., De Temmerman, L., Ene, A., Fernández, J.A., MartinezAbaigar, J., Frontasyeva, M., Godzik, B., Jeran, Z., Lazo, P., Leblond, S., Liiv, S., Magnússon, S.H., Maňkovská, B., Karlsson, G.P., Piispanen, J., Poikolainen, J. Santamaria, J.M., Skudnik, M., Spiric, Z., Stafilov, T., Steinnes, E., Stihi, C., Suchara, I., Thöni, L., Todoran, R., Yurukova, L., Zechmeister, H.G., 2015. Heavy metal and nitrogen concentrations in mosses are declining across Europe whilst some "hotspots" remain in 2010. Environ. Pollut. 200, 93-104. https://doi.org/10.1016/j. envpol. 2015.01.036.

Hellén, H., Praplan, A.P., Tykkä, T., Ylivinkka, I., Vakkari, V., Bäck, J., Petäjä, T. Kulmala, M., Hakola, H., 2018. Long-term measurements of volatile organic compounds highlight the importance of sesquiterpenes for the atmospheric chemistry of a boreal forest. Atmos. Chem. Phys. 18, 13839-13863. https://doi.org/ 10.5194/acp-18-13839-2018.

Hillamo, R.E., Maenhaut, W., Jaffrezo, J.L., Balachandran, S., Davidson, C.I., Kerminen, V.-M., 1993. Size distributions of atmospheric trace elements at Dye 3, Greenland-I. Distribution characteristics and dry deposition velocities. Atmos. Environ. 27A, 2787-2802.

Hyvärinen, A.-P., Kolmonen, P., Kerminen, V.-M., Virkkula, A., Leskinen, A., Komppula, M., Hatakka, J., Burkhart, J., Stohl, A., Aalto, P., Kulmala, M., Lehtinen, K.E.J., Viisanen, Y., Lihavainen, H., 2011. Aerosol black carbon at five background measurement sites over Finland, a gateway to the Arctic. Atmos. Environ. 45, 4042-4050.

Jalkanen, L., Häsänen, E., 1996. Simple method for the dissolution of atmospheric aerosol samples for analysis by inductively coupled plasma mass spectrometry. J. Anal. At. Spectrom 11 (5), 365-369.

Kashulina, G., de Caritat, P., Reimann, C., 2014. Snow and rain chemistry around the Severonikel industrial complex, NW Russia: current status and retrospective analysis. Atmos. Environ. 89, 672-682.

Kyllönen, K., Karlsson, V., Ruoho-Airola, T., 2009. Trace element deposition and trends during a ten year period in Finland. Sci. Total Environ. 407, 2260-2269.

Kyllönen, K., Paatero, J., Aalto, T., Hakola, H., 2014. Nationwide survey of airborne mercury in Finland. Boreal Environ. Res. 19 (Suppl. B), 355-367.

Laing, J.R., Hopke, P.K., Hopke, E.F., Husain, L., Dutkiewicz, V.A., Paatero, J., Viisanen, Y., 2014. Long-term particle measurements in Finnish arctic: Part I chemical composition and trace metal solubility. Atmos. Environ. 88, 275-284.

Liu, G., Cai, Y., O’Driscoll, N., Feng, X., Jiang, G., 2012. Overview of mercury in the environment. In: Liu, G., Cai, Y., O'Driscoll, N. (Eds.), Environmental Chemistry and Toxicology of Mercury. Wiley, New Jersey, pp. 1-12.

Lohila, A., Penttilä, T., Jortikka, S., Aalto, T., Anttila, P., Asmi, E., Aurela, M., Hatakka, J., Hellén, H., Henttonen, H., Hänninen, P., Kilkki, J., Kyllönen, K., Laurila, T., Lepistö, A., Lihavainen, H., Makkonen, U., Paatero, J., Rask, M., Sutinen, R., Tuovinen, J.-P., Vuorenmaa, J., Viisanen, Y., 2015. Preface to the special issue on integrated research of atmosphere, ecosystems and environment at Pallas. Boreal Environ. Res. 20, 431-454.

Makkonen, U., Hellen, H., Anttila, P., Ferm, M., 2010. Size distribution and chemical composition of airborne particles in south-eastern Finland during different seasons and wildfire episodes in 2006. Sci. Total Environ. 408, 644-651.

Moreno, T., Querol, X., Alastuey, A., de la Rosa, J., Sánchez de la Campa, A.M., Minguillón, M.C., Pandolfi, M., González-Castanedo, Y., Monfort, E., Gibbons, W., 2010. Variations in vanadium, nickel and lanthanoid element concentrations in urban air. Sci. Total Environ. 408, 4569-4579. https://doi.org/10.1016/j. scitotenv.2010.06.016.

Nguyen, Q.T., Skov, H., Sørensen, L.L., Jensen, B.J., Grube, A.G., Massling, A., Glasius, M., Nøjgaard, J.K., 2013. Source apportionment of particles at station nord, north east Greenland during 2008-2010 using COPREM and PMF analysis. Atmos. Chem. Phys. 13, 35-49.

Paatero, J., Vaattovaara, P., Vestenius, M., Meinander, O., Makkonen, U., Kivi, R., Hyvärinen, A., Asmi, E., Tjernström, M., Leck, C., 2009. Finnish contribution to the arctic summer cloud ocean study (ASCOS) expedition. Arctic Ocean 2008, Geophysica 45, 119-146.

Paatero, J., Dauvalter, V., Derome, J., Lehto, J., Pasanen, J., Vesala, T., Miettinen, J., Makkonen, U., Kyrö, E.-M., Jernström, J., Isaeva, L., Derome, K., 2008. Effects of Kola Air Pollution on the Environment in the Western Part of the Kola Peninsula and Finnish Lapland - Final Report, ISBN 978-951-697-686-3. ISNN 0782-6079, 26 p.

Paatero, P., Tapper, U., 1994. Positive matrix factorization: a non-negative factor model with optimal utilization of error estimates of data values. Environmetrics 5, $111-126$.

Paatero, P., 1997. Least squares formulation of robust non-negative factor analysis. Chemometr. Intell. Lab. Syst. 37, 23-35.

Paatero, P., Eberly, S., Brown, S.G., Norris, G.A., 2014. Methods for estimating uncertainty in factor analytic solutions. Atmos. Meas. Tech. 7, 781-797. https://doi. org/10.5194/amt-7-781-2014.

Pachon, J.E., Weber, R.J., Zhang, X., Mulholland, J.A., Russell, A.G., 2013. Revising the use of potassium $(\mathrm{K})$ in the source apportionment of PM2.5. Atmospheric Pollution Research 4, 14-21.

Pacyna, J.M., Pacyna, E.G., 2001. An assessment of global and regional emissions of trace metals to the atmosphere from anthropogenic sources worldwide. Environ. Rev. 9, 269-298.

Pacyna, J.M., Pacyna, E.G., Aas, W., 2009. Changes of emissions and atmospheric deposition of mercury, lead, and cadmium. Atmos. Environ. 43 (1), 117-127.

Pakkanen, T.A., Kerminen, V.-M., Korhonen, C.H., Hillamo, R.E., Aarnio, P., Koskentalo, T., Maenhaut, W., 2001. Use of atmospheric elemental size distributions in estimating aerosol sources in the Helsinki area. Atmos. Environ. 35, 5537-5551.

Pekney, N.J., Davidson, C.I., Zhou, L., Hopke, P.K., 2006. Application of PSCF and CPF to PMF-modeled sources of PM 2.5 in pittsburgh. Aerosol. Sci. Technol. 40 (10), 952-961. https://doi.org/10.1080/02786820500543324.

Pirrone, N., Cinnirella, S., Feng, X., Finkelman, R.B., Friedli, H.R., Leaner, J., Mason, R., Mukherjee, A.B., Stracher, G.B., Streets, D.G., Telmer, K., 2010. Global mercury emissions to the atmosphere from anthropogenic and natural sources. Atmos. Chem. Phys. 10, 5951-5964. https://doi.org/10.5194/acp-10-5951-2010.

Raatikainen, T., Brus, D., Hyvärinen, A.-P., Svensson, J., Asmi, E., Lihavainen, H., 2015. Black carbon concentrations and mixing state in the Finnish Arctic. Atmos. Chem. Phys. 15, 10057-10070.

Rolph, G., Stein, A., Stunder, B., 2017. Real-time environmental applications and display sYstem: ready. Environ. Model. Software 95, 210-228.

Ruoho-Airola, T., Anttila, P., Hakola, H., Ryyppö, T., Tuovinen, J.-P., 2015. Trends in the bulk deposition and atmospheric concentration of air pollutants in the Finnish integrated monitoring catchment Pallas during 1992-2012. Boreal Environ. Res. 20 553-569.

Saari, H., Salmi, J., Vestenius, M., Kyllönen, K., Makkonen, U., Wemberg, A., Laakia, J., Latikka, J., 2018. Outokumpu Stainless Oy, Air quality measurements in the vicinity of Tornio plant. Sulphur dioxide, mercury, inhalable particulates, arsenic, metal, PAH and ion concentrations in 2017. Final report. Only available in Finnish. Online. URL: http://expo.fmi.fi/aqes/public/Tornio_Outokumpu_Ilmanlaatumittausten_201 7_loppuraportti.pdf. (Jan 2020).

Salmi, T., Määttä, A., Anttila, P., Ruoho-Airola, T., Amnell, T., 2002. Detecting Trends of Annual Values of Atmospheric Pollutants by the Mann-Kendall Test and Sen's Slope Estimates - the Excel Template Application MAKESENS, vol. 31. Publications on ai quality, ISBN 951-697-563-1, 35 pp. Report Code FMI-AQ-31.

Schlesinger, W.H., Klein, E.M., Vengosh, A., 2017. Global biogeochemical cycle of vanadium. Proc. Natl. Acad. Sci. U.S.A. 114 (52), E11092-E11100. https://doi.org/ 10.1073 /pnas. 1715500114

von Schneidemesser, E., Schauer, J.J., Hagler, G.S.W., Bergin, M.H., 2009. Concentrations and sources of carbonaceous aerosol in the atmosphere of Summit, Greenland. Atmos. Environ. 43, 4155-4162.

Schroeder, W., Munthe, J., 1998. Atmospheric mercury-an overview. Atmos. Environ. 32, 809-822.

Selin, N., 2009. Global biogeochemical cycling of mercury: a review. Annu. Rev. Environ. Resour. 34, 43-63.

Sharma, S., Ishizawa, M., Chan, D., Lavoué, D., Andrews, E., Eleftheriadis, K. Maksyutov, S., 2013. 16-year simulation of Arctic black carbon: transport, source contribution, and sensitivity analysis on deposition. JGR Atmospheres 118, 943-964.

Stein, A.F., Draxler, R.R., Rolph, G.D., Stunder, B.J.B., Cohen, M.D., Ngan, F., 2015. Noaa's hysplit atmospheric transport and dispersion modeling System. Bull. Am. Meteorol. Soc. 96, 2059-2077.

Stohl, A, Wotawa, G., Seibert, P., Kromp-Kolb, H., 1995. Interpolation errors in wind fields as a function of spatial and temporal resolution and their impact on differen types of kinematic trajectories. J. Appl. Meteorol. 34, 2149-2165.

Stohl, A., Seibert, P., 1998. Accuracy of trajectories as determined from the conservation of meteorological tracers. Q. J. Roy. Met. Soc. 124, 1465-1484.

Suvarapu, L.N., Baek, S.O., 2017. Determination of heavy metals in the ambient atmosphere: a review. Toxicol. Ind. Health 33, 79-96.

Timonen, H., Teinilä, K., Aurela, M., Reyes, F., Vásquez, Y., Bloss, M., Oyol, P., Hillamo, R., Asmi, E., Saarikoski, S., 2018. Sources and composition of particulate matter in boreal arctic environment next to an active mining area. Boreal Environ. Res. 23, 105-125.

Tunved, P., Hansson, H.-C., Kerminen, V.-M., Ström, J., Dal Maso, M., Lihavainen, H., Viisanen, Y., Aalto, P.P., Komppula, M., Kulmala, M., 2006. High natural aerosol loading over Boreal forests. Science 312, 261-263.

Turpin, B.J., Saxena, P., Andrews, E., 2000. Measuring and simulating particulate organics in the atmosphere: problems and prospects. Atmos. Environ. 34, 2983-3013.

Vestenius, M., Leppänen, S., Anttila, P., Kyllönen, K., Hatakka, J., Hellén, H., Hyyärinen, A., Hakola, $\mathrm{H}, 2011$. Background concentrations and source 
apportionment of polycyclic aromatic hydrocarbons in South-Eastern Finland. Atmos. Environ. 45, 3391-3399.

Virkkula, A., Aurela, M., Hillamo, R., Mäkelä, T., Pakkanen, T., Kerminen, V.-M., Maenhaut, W., Francois, F., Cafmeyer, J., 1999. Chemical composition of atmospheric aerosol in the European subarctic: contribution of the Kola Peninsula smelter areas, central Europe, and the Arctic Ocean. J. Geophys. Res.: Atmosphere 104 (D19), 23681-23696.

Visschedijk, A.H.J., Denier van der Gon, H.A.C., Hulskotte, J.H.J., Quass, U., 2013. Anthropogenic vanadium emissions to air and ambient air concentrations in NorthWest Europe. E3S Web of Conferences 1, 03004.

von Storch, H., Costa-Cabral, M., Hagner, C., Feser, F., Pacyna, J., Pacyna, E., Kolb, S. 2003. Four decades of gasoline lead emissions and control policies in Europe: a retrospective assessment. Sci. Total Environ. 311 (1-3), 151-176.

Wang, J., Pan, Y.P., Tian, S.L., Chen, X., Wang, L., Wang, Y.S., 2016. Size distributions and health risks of particulate trace elements in rural areas in northeastern China. Atmos. Res. 168, 191-204. https://doi.org/10.1016/j.atmosres.2015.08.019.
Winiger, P., Andersson, A., Eckhardt, S., Stohl, A., Gustafsson, O., 2016. The sources of atmospheric black carbon at a European gateway to the Arctic. Nat. Commun. 7 , 12776.

Wängberg, I., Munthe, J., 2001. Atmospheric Mercury in Sweden, Northern Finland and Northern Europe. Results from National Monitoring and European Research. IVL Swedish Environmental Research Institute, p. 16. IVL report B1399.

Wängberg, I., Aspmo Pfaffhuber, K., Berg, T., Hakola, H., Kyllönen, K., Munthe, J., Porvari, P., Verta, M., 2010. Atmospheric and Catchment Mercury Concentrations and Fluxes in Fennoscandia. Scientific Report TemaNord 2010, vol. 594. Nordic Council of Ministers, Copenhagen, ISBN 978-92-893-2162-4, 2010.

Yamauchi, H., Fowler, B.A., 1994. Toxicity and metabolism of inorganic and methylated arsenicals. In: Nriagu, J.O. (Ed.), Arsenic in the Environment, Part II: Human Health and Ecosystem Effects. Wiley, New York, pp. 35-43.

Yli-Tuomi, T., Venditte, L., Hopke, P.K., Shamsuzzoha Basunia, M., Landsberger, S., Viisanen, Y., Jussi Paatero, J., 2003. Composition of the Finnish Arctic aerosol: collection and analysis of historic filter samples. Atmos. Environ. 37, 2355-2364. 


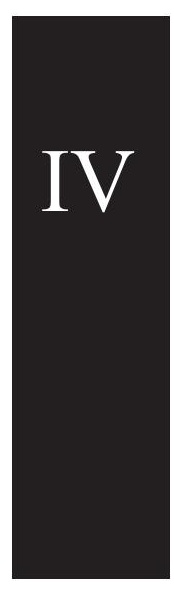





\title{
Trace element deposition and trends during a ten year period in Finland
}

\author{
Katriina Kyllönen*, Vuokko Karlsson, Tuija Ruoho-Airola \\ Finnish Meteorological Institute, Air Quality Department, P.O. Box 503, FIN-00101 Helsinki, Finland
}

\section{A R T I C L E D A T A}

\section{Article history:}

Received 12 September 2008

Received in revised form

14 November 2008

Accepted 15 November 2008

Available online 30 December 2008

\section{Keywords:}

Trace element

Precipitation

Trend

Deposition

Measurement uncertainty

Enrichment factor

\begin{abstract}
A B S T R A C T
The deposition of aluminium, arsenic, cadmium, chromium, copper, iron, lead, manganese, nickel, vanadium and zinc in bulk precipitation was examined at eight background stations in Finland during the last 10 years (1998-2007). The annual deposition was from the lowest values to the highest $\mathrm{Cd}<\mathrm{As}<\mathrm{Cr}<\mathrm{Ni}<\mathrm{V}<\mathrm{Cu}$ and $\mathrm{Pb}<\mathrm{Mn}<\mathrm{Zn}<\mathrm{Al}<\mathrm{Fe}$. Most of the elements had a south to north decreasing gradient mainly due to minor domestic emissions in the north, growing distance to the large European source areas and differences in the length of snow-cover period. Element enrichment factors divided the trace elements to the following categories: (1) slightly enriched $\mathrm{Cr}, \mathrm{Fe}$ and $\mathrm{Mn}$; (2) moderately enriched $\mathrm{Cu}$, Ni and V; and (3) highly enriched As, $\mathrm{Cd}, \mathrm{Pb}$ and $\mathrm{Zn}$. Trend analysis of annual depositions showed that the established decreasing trend in $\mathrm{As}$ and $\mathrm{Pb}$ deposition continued during our study period while $\mathrm{Cr}, \mathrm{Cu}$ and $\mathrm{Fe}$ depositions have lately increased. No statistically significant trends were detected for $\mathrm{Cd}, \mathrm{Mn}, \mathrm{Ni}, \mathrm{V}$ and $\mathrm{Zn}$ during the studied years. Additionally, the measurement uncertainty of trace elements was evaluated for the whole measurement chain.
\end{abstract}

(c) 2008 Elsevier B.V. All rights reserved.

\section{Introduction}

Trace elements exist in igneous rocks, sediments and soil as natural constituents. Their concentrations in the atmosphere have increased substantially since the 19th century due to human activity (e.g. Galloway et al., 1982). Many trace elements are commonly released to the atmosphere through high temperature processes. Major anthropogenic sources of trace elements include stationary fossil fuel combustion (e.g. $\mathrm{Cr}, \mathrm{Mn}, \mathrm{Ni}, \mathrm{V}$ ), non-ferrous metal production (e.g. As, Cd, Cu, $\mathrm{Zn}$ ) and combustion of gasoline (Pb) (Pacyna and Pacyna, 2001).

Trace element emissions were reduced in the 1980-1990's due to strict emission regulations and consequent improvements in the control technologies. Emission scenarios predict a further decrease in the emissions in this century (ESPREME, 2008). Monitoring wet deposition is a straight forward tool to follow the environmentally soluble amount of the pollutants that are transported from the atmosphere to aquatic and terrestrial ecosystems and thus become bioavailable and expose a threat to human health.

Monitoring of heavy metals (HM) in precipitation began extensively in the 1970's (e.g. Peirson et al., 1973) after discovering the dangers of HM emissions. Time series of the heavy metal deposition in bulk precipitation in Finland are available from the late 1980's for cadmium and lead, and the HM measuring program was extended in 1991 to include copper and zinc and, at some stations, chromium, iron, manganese, nickel and vanadium. Since the late 1990's, the Finnish Meteorological Institute (FMI) has monitored the deposition of $\mathrm{Al}, \mathrm{As}, \mathrm{Cd}, \mathrm{Co}, \mathrm{Cr}, \mathrm{Cu}, \mathrm{Fe}, \mathrm{Mn}, \mathrm{Ni}, \mathrm{Pb}, \mathrm{V}$ and $\mathrm{Zn}$ at 7-8 background stations around the country.

Trace elements in particulates are removed from the atmosphere by wet deposition by in-cloud and below-cloud processes or by dry deposition processes. Particulate and gas

\footnotetext{
* Corresponding author. Tel.: +358 9 19295461; fax: +358 919295403.

E-mail address: katriina.kyllonen@fmi.fi (K. Kyllönen).
} 
phase deposition of the trace elements in Finland have been studied less than wet deposition and mostly in short time projects. The mass amount of dry deposition is dependent on the atmospheric concentration of the elements and an alternating deposition velocity. Several meteorological variables and the character of the receptor control the deposition velocity. In a Swedish flux measurement experiment, Foltescu et al. (1994) estimated that the amount of dry deposition was $10-15 \%$ of wet deposition for $\mathrm{Cu}, \mathrm{Pb}$ and $\mathrm{V}, 25 \%$ for $\mathrm{Ni}$ and $\mathrm{Zn}$, and $85 \%$ for $\mathrm{Mn}$. In Finland, atmospheric concentrations of trace elements have been monitored continuously only in the North at Pallas since 1996 and PM10 fraction of trace elements at two additional stations since 2006 .

The aim of the paper is to report the results for the bulk deposition of 11 trace elements (Al, As, Cd, Cr, Cu, Fe, Mn, Ni, $\mathrm{Pb}, \mathrm{V}$ and $\mathrm{Zn}$ ) during the last 10 years. Enrichment factors are presented for each element to give an indication of the origin of these pollutants. A special focus is given on the temporal trends in the data, and the results are compared with emission data from ESPREME (EU 6th Framework Programme Integrated Assessment of Heavy Metal Releases in Europe), UNECE/LRTAP/EMEP (United Nations Economic Commission for Europe/Co-operative Programme for Monitoring and Evaluation of the Long-range Transmissions of Air Pollutants in Europe) and EPER (European Pollutant Emission Register). Finally, measurement uncertainty estimates for the studied elements are provided including both the sampling and the analytical stages.

After the clear decreasing trends seen in the trace element deposition in the 1980's and 1990's in Europe (Matschullat et al., 2000; Rühling and Tyler, 2001; Poikolainen et al., 2004; Harmens et al., 2007, 2008), studies of the present-day situation in the current decade are needed. According to our results, there are still some changes occurring. However, the deposition data do not fully reflect the decrease reported in the official emission databases, which, on the other hand, have high uncertainties and shortages (Ilyin et al., 2007). Therefore, transport models, which use the emissions as a starting value, may also give inaccurate results and not show the trends correctly. Our findings provide information about the wet deposition part of the trace element load on the ecosystem and how it is currently changing. Later, the rate of the dry deposition of the load can additionally be studied when the monitoring of the aerosol concentration of trace elements covers long enough time series from different areas.

\section{Experimental}

\subsection{Site description}

The precipitation samples for trace metal analysis were collected at seven Finnish background stations (Fig. 1). The stations are Virolahti (abbreviated VIR in tables), Kotinen (KOT), Hietajärvi (HIE), Hailuoto (HAI), Kuusamo (KUU), Pallas (PAL) and Utsjoki (UTS). Until 2004, samples were collected also at the southernmost station Utö (UTO). Most of these stations belong to international monitoring programmes such as AMAP (Arctic Monitoring and Assessment Programme),

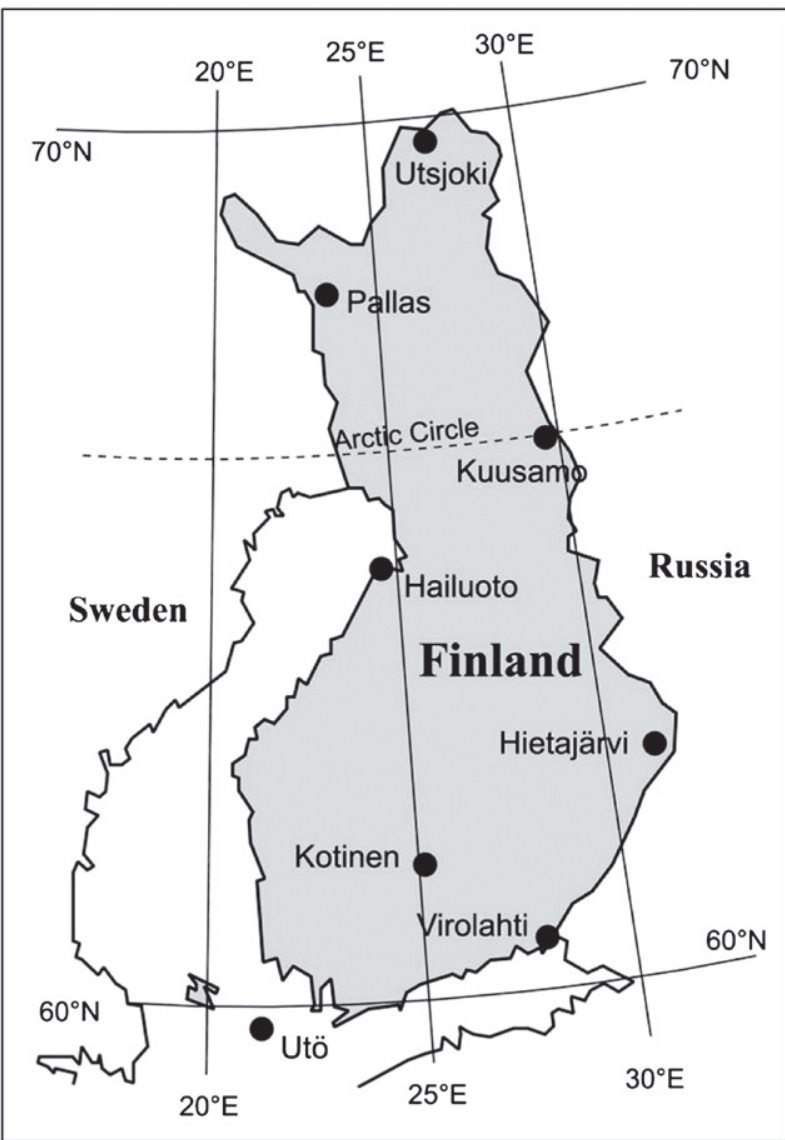

Fig. 1-Precipitation samples for trace metal analysis are collected at eight Finnish background stations. At the southernmost station Utö, the sampling ended after 2003.

UNECE/LRTAP/EMEP, WMO/GAW (World Meteorological Organization Global Atmosphere Watch), HELCOM (Baltic Sea Protection Commission) or UNECE/LRTAP/IM (Integrated Monitoring). The stations have been chosen to cover the country area and present the typical background areas (forested, agricultural) in Finland. They are located far from pollutant sources like heavy traffic and industry. Description of the stations is given in Table 1.

Data from the Utsjoki station are a combination of two stations Vuoskojärvi and Kevo. The Vuoskojärvi station was closed in 2000 and sampling was relocated to Kevo $3.5 \mathrm{~km}$ away. The data from Vuoskojärvi is from 1998-1999 and Kevo from 2000-2007. The same applies also for the Kuusamo station, which covers data from stations Pesosjärvi (19981999) and Oulanka (2000-2007) $5 \mathrm{~km}$ apart. During 2000, a field study was organised at Utsjoki and Kuusamo to compare the similarity of data from the two different stations at both locations. The results were consistent. Therefore, the data are presented as being from the same station at these two districts.

\subsection{Sampling and chemical analysis}

The precipitation samples for trace metal analysis were collected monthly at the Finnish background stations and 
Table 1 - Description of the measuring stations

\begin{tabular}{|c|c|c|c|c|}
\hline Station & Altitude (m, asl) & Average temperature $\left({ }^{\circ} \mathrm{C}\right)$ & $\begin{array}{c}\text { Average annual } \\
\text { precipitation }(\mathrm{mm})\end{array}$ & Surroundings \\
\hline UTO & 7 & 7.1 & 556 & Island station, open to marine climate \\
\hline VIR & 4 & 4.9 & 659 & Coastal, mostly agricultural with small forests \\
\hline KOT & 158 & 4.4 & 642 & Old forest, peatland, lake \\
\hline HIE & 173 & 2.3 & 732 & Peatland, old forest, lake \\
\hline HAI & 4 & 3.1 & 529 & Island station, immediate surroundings agricultural \\
\hline KUU & $310^{\mathrm{a}}$ & 0.2 & 537 & Upland coniferous forest \\
\hline PAL & 340 & -0.5 & 572 & Upland coniferous forest \\
\hline UTS & $107^{\mathrm{b}}$ & -0.9 & 445 & Hillside area, open surroundings with alpine birch \\
\hline
\end{tabular}

prepared in the laboratory according to the EMEP Manual for sampling and chemical analysis (EMEP/CCC, 2001). Two or three replicate samples were collected at the same time with NILU-type bulk deposition samplers. After arriving at the laboratory, the samples were conserved in nitric acid and then refrigerated in the dark for $48 \mathrm{~h}$. The samples were analysed using an inductively coupled plasma mass spectrometer (PerkinElmer Sciex Elan 6000). The determination method was based on the standard ASTM D5673-96 with a few minor exceptions adapted from the EMEP manual or method development conducted by the laboratory. The calibration solutions were prepared gravimetrically from commercial standard solutions (Merck). Traceability was achieved with commercial certified reference samples (e.g. TMRAIN-95, National Water Research Institute, Canada) and the EMEP analytical intercomparisons of heavy metals in precipitation.

\subsection{EF analysis}

Many elements occur in the environment at higher concentrations than expected from their natural occurrence in the aquatic and terrestrial environment. Thus, they are called to be enriched.

Enrichment factors (EF) were used to estimate whether the source of the element in precipitation is of anthropogenic or natural origin. This method compares the amount of the element to a reference element assumed to be entirely from crustal sources (e.g. Al, Fe). Here the reference element is aluminium. The enrichment factor is defined as:

$E F($ crust $)=\frac{(\mathrm{X} / \mathrm{Al}) \text { precipitation }}{(\mathrm{X} / \mathrm{Al}) \text { crust }}$

where $(\mathrm{X} / \mathrm{Al})$ precipitation and $(\mathrm{X} / \mathrm{Al})$ crust refer to the ratio of the concentrations of metal $\mathrm{X}$ to that of $\mathrm{Al}$ in the precipitation and in average crustal material, respectively (Wiersma and Davidson, 1986). The average amounts of the elements in crustal rock are found in Mason (1966). The EF value near unity suggests that the source of the element is mostly crustal erosion while elements with values larger than about 4 have some other source. This may be anthropogenic but could also be due to other natural processes that enhance the amount of the element compared to its crustal abundance. Here, the enrichment values for 1998-2007 were calculated as the median of monthly EF values for each element. Furthermore, the dependence of each season was studied.

\subsection{Trend calculation}

The trends in the annual trace element depositions were estimated using the nonparametric Mann-Kendall test (Gilbert, 1987; Salmi et al., 2002). This method is applicable to the detection of a monotonic increasing or decreasing trend of a time series with no seasonal or other cycle. The trend was tested at significance levels $P<0.1, P<0.05, P<0.01$ and $P<0.001$ as a two-tailed test. Additionally, the nonparametric Sen's method was used to detect the magnitude of the trend as a slope of a linear trend, and the $95 \%$ confidence interval for the slope estimator was calculated.

An estimate for the total change $\Delta C$ of annual values was calculated using Sen's slope estimator $(Q)$ extracted from the annual values and assuming a linear trend over the length of the period ( $\Delta t$ ) (Ruoho-Airola et al., 2004),

$$
\Delta C=Q \Delta t
$$

The total change was then related to the value of the first year of the fitted trend line equation $\left(C_{1}\right)$ :

$$
C_{i}=Q t_{i}+B
$$

The constant term B was calculated as the median of the terms $f\left(t_{i}\right)-Q t_{i}$, where $f\left(t_{i}\right)$ is the annual value of year $t_{i}$ in the time series. The relative total change $R$ indicated as a percentage is

$R=\frac{100 \Delta C}{C_{1}}$.

\subsection{Replacement of missing values}

There were two occasions in the data where monthly deposition values were missing when there had been rain and a few other times when the precipitation sample had 
clearly been contaminated. Missing values can have an effect on the observed trend, and thus, replacing data points are needed. For the annual deposition values and the trend calculations the missing monthly values were replaced by a weighted arithmetic mean deposition value calculated from the data from the previous and following month. These 2 months were selected to best present the deposition of the year and time of year in question. The formula for calculations was adapted from Hjellbrekke (2000),

$c(x)=\frac{1}{\sum_{i} p_{i}} \cdot \sum c_{i} \cdot p_{i}$

where $c(x)$ is the precipitation weighted arithmetic mean concentration and $p_{i}$ is precipitation amount month $i$ with the measured concentration $c_{i}$ of a specific component.

\subsection{Calculation of measurement uncertainty}

The measurement uncertainty was estimated using the equation for data from paired measurements of two identical measuring systems, type A6 (ISO, 2007). The expanded measurement uncertainty is calculated using Eq. (6).

$\mathrm{U}_{p}(\mathrm{y})=\mathrm{k} \cdot \mathrm{u}(\mathrm{y})$

where

$U_{p}(y) \quad$ is the expanded uncertainty with a coverage probability $p$

$u(y) \quad$ is the standard uncertainty

$k \quad$ is the coverage factor.

Table 2 - The annual deposition (in $\mu \mathrm{g}^{-2}$ ) of the elements at two Finnish background stations Virolahti and Pallas during 1998-2007

\begin{tabular}{|c|c|c|c|c|c|c|c|c|c|c|}
\hline Element & 1998 & 1999 & 2000 & 2001 & 2002 & 2003 & 2004 & 2005 & 2006 & 2007 \\
\hline \multicolumn{11}{|l|}{ Aluminium } \\
\hline VIR & 23,000 & 24,000 & 22,000 & 21,000 & 18,000 & 16,000 & 16,000 & 17,000 & 15,000 & 30,000 \\
\hline PAL & 2900 & 3300 & 2900 & 2900 & 2400 & 2700 & 2400 & 2700 & 2900 & 2000 \\
\hline \multicolumn{11}{|l|}{ Arsenic } \\
\hline VIR & 140 & 110 & 140 & 94 & 53 & 74 & 81 & 96 & 100 & 89 \\
\hline PAL & 64 & 51 & 67 & 36 & 18 & 33 & 55 & 47 & 28 & 15 \\
\hline \multicolumn{11}{|l|}{ Cadmium } \\
\hline VIR & 41 & 38 & 53 & 43 & 27 & 40 & 34 & 41 & 27 & 38 \\
\hline PAL & 12 & 13 & 12 & 10 & 8 & 16 & 18 & 12 & 9 & 12 \\
\hline \multicolumn{11}{|l|}{ Chromium } \\
\hline VIR & 79 & 130 & 89 & 52 & 95 & 120 & 140 & 180 & 98 & 180 \\
\hline PAL & 22 & 51 & 48 & 21 & 37 & 61 & 93 & 70 & 32 & 43 \\
\hline \multicolumn{11}{|l|}{ Copper } \\
\hline VIR & 670 & 390 & 500 & 480 & 470 & 710 & 600 & 820 & 870 & 1000 \\
\hline PAL & 500 & 370 & 390 & 340 & 310 & 520 & 570 & 650 & 570 & 580 \\
\hline \multicolumn{11}{|l|}{ Iron } \\
\hline VIR & 19,000 & 21,000 & 20,000 & 21,000 & 22,000 & 20,000 & 22,000 & 34,000 & 23,000 & 51,000 \\
\hline PAL & 3100 & 3700 & 4200 & 3600 & 4500 & 7700 & 8300 & 8500 & 5300 & 4900 \\
\hline \multicolumn{11}{|l|}{ Manganese } \\
\hline VIR & 2100 & 2000 & 1900 & 1600 & 1700 & 1400 & 1600 & 2000 & 1400 & 2300 \\
\hline PAL & 570 & 630 & 770 & 750 & 600 & 580 & 920 & 880 & 840 & 630 \\
\hline \multicolumn{11}{|l|}{ Lead } \\
\hline VIR & 1000 & 880 & 1500 & 860 & 660 & 810 & 800 & 1000 & 840 & 1100 \\
\hline PAL & 290 & 410 & 360 & 260 & 240 & 250 & 430 & 360 & 200 & 180 \\
\hline \multicolumn{11}{|l|}{ Nickel } \\
\hline VIR & 240 & 160 & 180 & 110 & 170 & 220 & 180 & 140 & 130 & 140 \\
\hline PAL & 120 & 98 & 91 & 59 & 64 & 160 & 190 & 130 & 96 & 53 \\
\hline \multicolumn{11}{|l|}{ Vanadium } \\
\hline VIR & 380 & 340 & 370 & 300 & 280 & 280 & 320 & 320 & 290 & 360 \\
\hline PAL & 94 & 120 & 100 & 84 & 52 & 69 & 110 & 140 & 98 & 94 \\
\hline \multicolumn{11}{|l|}{ Zinc } \\
\hline VIR & 5300 & 2300 & 3000 & 2.400 & 2600 & 2700 & 2700 & 3300 & 3400 & 3800 \\
\hline PAL & 930 & 1400 & 950 & 1100 & 920 & 1400 & 2200 & 1600 & 1100 & 930 \\
\hline
\end{tabular}


A coverage factor $(k)$ of 2 is used to obtain the expanded uncertainty at the $95 \%$ confidence interval. The standard uncertainty is calculated according Eq. (7).

$u(y)=\sqrt{\frac{\sum_{j=1}^{N}\left(y_{(1, j)}-y_{(2, j)}\right)^{2}}{2 N}}$

where

$y_{(1, j)} \quad$ is the value in parallel sampler 1

$y_{(2, j)} \quad$ is the value in parallel sampler 2

$\mathrm{N}$ is the number of parallel samples.

\section{Results and discussion}

\subsection{Deposition of the elements}

Arranged from lowest to highest values, the bulk deposition of the studied elements was $\mathrm{Cd}<\mathrm{As}<\mathrm{Cr}<\mathrm{Ni}<\mathrm{V}<\mathrm{Cu}$ and $\mathrm{Pb}<\mathrm{Mn}<\mathrm{Zn}<\mathrm{Al}<\mathrm{Fe}$. The annual deposition of the elements at two example stations is shown in Table 2. These stations, Virolahti and Pallas, represent Southern Finland and Northern Finland, respectively. Data for other stations are given in supplementary data provided in the journal web pages www. elsevier.com. Mostly the elements follow a south-to-north gradient (Fig. 2 for As). This is typically due to minor domestic emissions in the north and longer distance to the large European source areas in the north than in the south. Additionally, length of snow-cover period has an effect on re-suspension of some elements. The southernmost station Utö has slightly smaller deposition than expected considering the gradient. This is explained by the fact that Utö has a low annual precipitation amount. Also, Utö is a marine station far away from possible sources except ship emissions.

Here the elements are divided into three different groups. The partition of the elements is discussed further in the Section 3.2.

\subsubsection{Group I elements: $\mathrm{Al}, \mathrm{Cr}, \mathrm{Fe}$ and $\mathrm{Mn}$}

Group I consists of the elements aluminium, chromium, iron and manganese. They all have a south to north gradient, but it

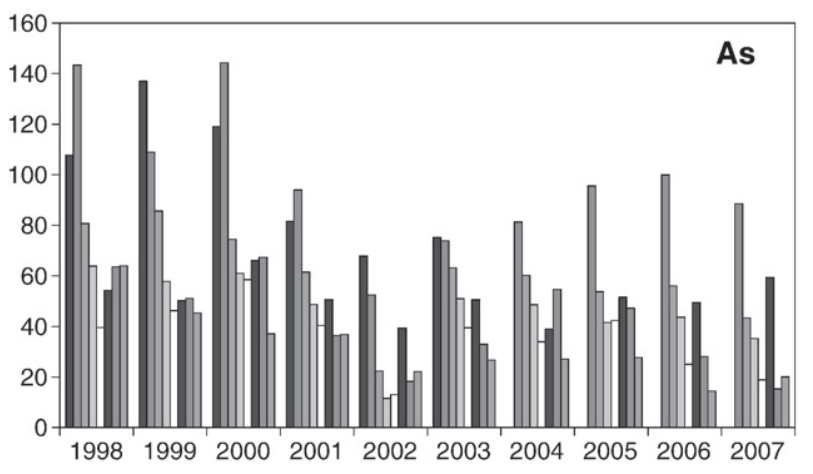

Fig. 2-The annual deposition (in $\mu \mathrm{g} \mathrm{m}^{-2}$ ) of As at Finnish background stations in south to north order: Utö, Virolahti, Kotinen, Hietajärvi, Hailuoto, Kuusamo, Pallas and Utsjoki.

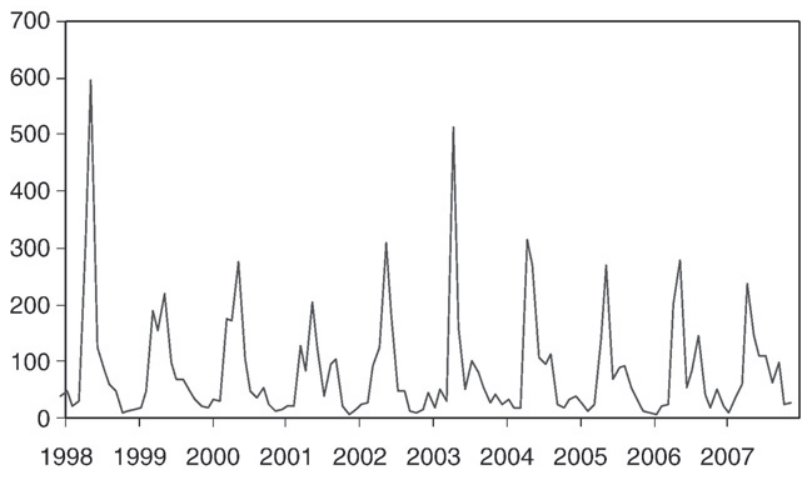

Fig. 3-Monthly deposition of $\mathrm{Mn}$ (in $\mu \mathrm{g} \mathrm{m}^{-2}$ ) at Hietajärvi station during 1998-2007.

is most obvious for $\mathrm{Al}$ and Fe. For these elements the seasonal variation is clearest. The highest values are seen in May and June when all the snow has melted and there is a lot of windblown dust in the air (Fig. 3 for $\mathrm{Mn}$ at the Hietajärvi station).

\subsubsection{Group II elements: $\mathrm{Cu}, \mathrm{Ni}$ and $\mathrm{V}$}

Group II consists of the elements copper, nickel and vanadium. While $\mathrm{V}$ has a strong south-to-north gradient, $\mathrm{Cu}$ and $\mathrm{Ni}$ have a different behaviour. $\mathrm{Cu}$ and Ni first decrease towards the north but then start to increase again in Northern Finland. The levels of $\mathrm{Cu}$ and especially $\mathrm{Ni}$ from the northernmost station, Utsjoki, were nearly equivalent or greater than that found in Southern Finland. Even the deposition at Pallas station, which is about $250 \mathrm{~km}$ southwest of Utsjoki station, is similar to that at the southern Virolahti station as can be seen in Table 2. This phenomenon, which is only typical for these two elements, is due to the emissions of the large $\mathrm{Cu}-\mathrm{Ni}$ smelters in the Kola Peninsula that has been reported e.g. in Jaffe et al. (1995) and Kubin and Lippo (1996).

The deposition of $\mathrm{V}$ is clearly elevated at all the Finnish coastal stations (Fig. 1). These areas are affected by emissions associated with heavy shipping. Oil combustion is a major source of V and Ni according to Pacyna and Pacyna (2001). The use of low grade residual oil in large marine diesel engines is the likely cause for the elevated levels of $\mathrm{V}$. In addition to $\mathrm{Cu}-$ Ni smelters, residual oil is expected to be a significant source of nickel.

\subsubsection{Group III elements: $\mathrm{As}, \mathrm{Cd}, \mathrm{Pb}$ and $\mathrm{Zn}$}

Group III consists of the elements arsenic, cadmium, lead and zinc. With the exception of zinc, these are also among the four trace elements that the European Union Directives 1999/30/EC (EU, 1999) and 2004/107/EC (EU, 2005) oblige the Member States to monitor as a part of their ambient air quality programs. These directives were established e.g. to reduce pollution to levels which minimise harmful effects on human health and the environment as a whole, to improve the monitoring and assessment of air quality including the deposition of pollutants and to provide information to the public (EU, 2005).

The deposition of $\mathrm{Cd}, \mathrm{Pb}$ and $\mathrm{Zn}$ follows the south-to-north gradient strongly suggesting long range transport from densely populated and heavily industrialised regions in Europe. Arsenic has the same kind of gradient but it fades in 
the north. Emissions from the smelters in Kola Peninsula are a likely explanation for the elevated As level. Additionally, there is often a surprisingly large peak for arsenic at Kuusamo when compared to other stations. Usually the peak is a result of one single elevated monthly deposition, which happens repeatedly in August. Also chromium, copper and zinc tend to peak at the same time although not as sharply. This phenomenon cannot be explained and is likely to be of local or regional influence. The long sampling time does not enable analysis of the source areas with the help of trajectories.

Occasional local heavy rainfalls produce more evident monthly peaks affecting the deposition amount for the whole year to rise. This happened for example at Pallas in 2004 when the rain amount in July was $227 \mathrm{~mm}$, which was about $30 \%$ of that year's total. This heavy rain month increased the deposition of all the elements that year.

\subsubsection{Data comparison with other closely located EMEP} stations

The annual deposition results from this study were compared with EMEP data from countries nearby Finland. The countries and stations selected for comparison were Sweden/Arup, Norway/Birkenes and Germany/Zingst located southwest of Finland. None of the EMEP countries monitor such a variety of trace elements in the more northern latitudes as Finland. The only exception is Svanvik in Norway, but the deposition data of that station is strongly affected by the heavy industrial activities in Nikel in Kola Peninsula only $9 \mathrm{~km}$ away, and hence, those data were not included in this comparison.

As suspected, the trace element deposition in Southern Finland was generally lower or about the same level as in the reference stations. The Norwegian station had typically higher deposition than the other stations. Surprisingly, the German station often had lower As and Cd deposition than southern Finland or the other Scandinavian stations.

\subsection{Enrichment factors}

The enrichment values of the elements are shown in Fig. 4. The value was calculated as the median of all the years separately for each station. Fe, $\mathrm{Cr}$ and $\mathrm{Mn}$ had values less than or close to 10 (Group I). Fe was generally of crustal origin, while $\mathrm{Cr}$ and Mn were slightly enriched with crustal weathering still

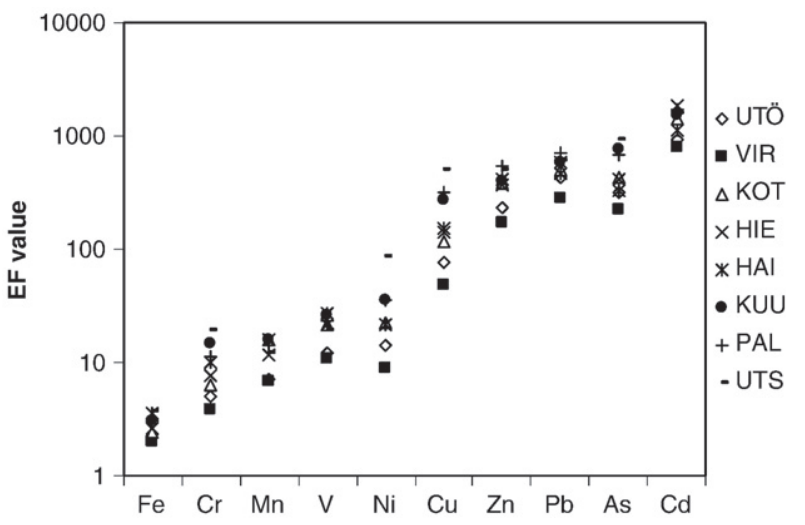

Fig. 4-The median enrichment factors of the trace elements at the stations in 1998-2007. remaining an important source of the elements. $V$ and Ni had values of 10-100, which corresponds to intermediate enrichment (Group II). Also, $\mathrm{Cu}$ had values close to 100 except in Northern Finland where the values indicate high enrichment. It is evident from the high $\mathrm{EF}$ values of $\mathrm{Cu}$ and $\mathrm{Ni}$ in the north that there is a strong regional anthropogenic source for these elements as discussed in Section 3.1.2. $\mathrm{Zn}, \mathrm{Pb}, \mathrm{As}$ and $\mathrm{Cd}$ (Group III) are highly enriched with EF values significantly greater than 100 and thus, mostly of anthropogenic origin.

The seasonal differences in EF values were calculated to estimate whether the significance of crustal versus other (usually anthropogenic) sources changed. As, $\mathrm{Cd}, \mathrm{Pb}$ and $\mathrm{Zn}$ showed clear seasonality with higher values in the winter than in the summer while the crustal elements $\mathrm{Cr}$ and Fe had less seasonality. On the contrary, Mn had greater EF values in the summer and early autumn. There were hardly any monthly variations in the EF values of the southern station Virolahti. This indicates that crustal erosion is the source of aluminium in Virolahti to a lesser extent than elsewhere.

\subsection{Trend analysis}

For the trend analysis, data were used from all of the stations during the 10 years studied. The trends for the Utö station could not be calculated because of the short time series. The deposition of elements generally decreased during the study period although the statistical significance of the trend is usually weak. However, the deposition of the elements $\mathrm{Cr}, \mathrm{Cu}$, and $\mathrm{Fe}$ has increased in the last few years resulting in an upward trend. The significant trends of the elements are presented in Table 3 . When the $95 \%$ minimum and maximum confidence intervals of Sen's slope estimate settle on opposite sides of zero, the slope has been discarded from the table and the change is given as a decreasing or increasing trend instead of a numerical value of the slope. None of the studied elements had a significant trend at all the background stations. Since the time series is relatively short (10 years) the significance of the trends for the above mentioned elements was usually rather weak $(P>0.1)$. The test shows no statistically significant trends for $\mathrm{Cd}, \mathrm{Mn}, \mathrm{Ni}, \mathrm{V}$ and $\mathrm{Zn}$ during the years studied.

\subsubsection{As and $\mathrm{Pb}$}

Arsenic showed a considerable decrease of up to $70 \%$ in the northernmost station. This is mostly due to anthropogenic emission reductions both in Finland and elsewhere in Europe. In the ESPREME Source-sector analysis and evaluation report, the emissions of As, $\mathrm{Cd}$ and $\mathrm{Pb}$ during 1955-2000 and future emission scenarios for the above mentioned elements were presented (Pacyna, 2007). For arsenic, the European atmospheric emissions have declined from approximately 12,000 $t$ in the 1960's to about $1000 \mathrm{t}$ in 2000. The future emission scenarios predict a $20-40 \%$ reduction in As emissions between 2000 and 2010. Between 1990 and 2000, the arsenic concentrations in mosses in Europe have declined by $75 \%$ (Harmens et al., 2007). However, this result is based on the data from only five countries. The emissions in countries southwest or west affect the deposition in Finland most since the main prevailing wind directions are from these regions. These countries include the highly industrialised Poland with high As 
Table 3 - The trend significance TS $\left({ }^{* *}, \mathrm{P} \quad 0.01 ;{ }^{*}, \mathrm{P} \quad 0.05 ;+, \mathrm{P} \quad 0.1\right.$ ), Sen's slope estimate Est. (in $\left.\mu \mathrm{g} \mathrm{m}^{-2} \mathrm{yr}^{-1}\right)$ with its $95 \%$ confidence interval ( $\min , \mathrm{max}$ ), and the relative total change per period for the annual deposition of $\mathrm{Al}, \mathrm{As}, \mathrm{Cr}, \mathrm{Cu}, \mathrm{Fe}, \mathrm{and} \mathrm{Pb}$ in 1998-2007

\begin{tabular}{|c|c|c|c|c|c|c|c|c|c|c|}
\hline \multirow[t]{2}{*}{ Station } & \multirow[t]{2}{*}{ TS } & \multicolumn{3}{|c|}{ Slope per year } & \multirow{2}{*}{$\begin{array}{c}\text { Change, } \\
\%\end{array}$} & \multirow[t]{2}{*}{ TS } & \multicolumn{3}{|c|}{ Slope per year } & \multirow{2}{*}{$\begin{array}{c}\text { Change, } \\
\%\end{array}$} \\
\hline & & Est. & Min. & Max. & & & Est. & Min. & Max. & \\
\hline & Aluminium & & & & & Copper & & & & \\
\hline VIR & n.s. & & & & & * & 62 & 23 & 96 & 150 \\
\hline KOT & + & - & - & - & decr & n.s. & & & & \\
\hline HIE & n.s. & & & & & + & - & - & - & incr \\
\hline HAI & n.s. & & & & & * & 34 & 2.2 & 77 & 98 \\
\hline KUU & + & - & - & - & decr & $*$ & 34 & 2.1 & 72 & 100 \\
\hline PAL & n.s. & & & & & $*$ & - & - & - & incr \\
\hline \multirow[t]{2}{*}{ UTS } & * & - & - & - & decr & n.s. & & & & \\
\hline & Arsenic & & & & & Iron & & & & \\
\hline VIR & n.s. & & & & & * & 950 & 270 & 3600 & 47 \\
\hline KOT & * & -3.9 & -5.6 & -2.0 & -43 & n.s. & & & & \\
\hline HIE & * & -2.7 & -4.5 & -1.6 & -39 & n.s. & & & & \\
\hline HAI & n.s. & & & & & n.s. & & & & \\
\hline KUU & n.s. & & & & & n.s. & & & & \\
\hline PAL & * & -4.4 & -11 & 0.0 & -67 & * & 330 & 120 & 890 & 90 \\
\hline \multirow[t]{2}{*}{ UTS } & $* *$ & -3.8 & -6.3 & -1.9 & -70 & n.s. & & & & \\
\hline & Chromium & & & & & Lead & & & & \\
\hline VIR & * & 9.3 & 0.2 & 20 & 110 & n.s. & & & & \\
\hline KOT & $*$ & 5.2 & 1.3 & 8.8 & 130 & $*$ & -28 & -55 & -10 & -35 \\
\hline HIE & n.s. & & & & & n.s. & & & & \\
\hline HAI & * & 9.6 & 0.6 & 14 & 280 & n.s. & & & & \\
\hline KUU & + & - & - & - & incr & * & -16 & -29 & 0.1 & -40 \\
\hline PAL & n.s. & & & & & n.s. & & & & \\
\hline UTS & n.s. & & & & & * & -14 & -25 & -3.9 & -54 \\
\hline
\end{tabular}

n.s. = Not significant.

decr $=$ Decreasing trend.

incr $=$ Increasing trend.

emissions. The Polish As emissions have decreased approximately 10\% from 2001 to 2006 (UNECE/EMEP, 2008). Moreover, ESPREME (2008) estimated a decrease of 59\% in Poland during 2000-2010. Since the deposition decrease has been more effective in the north than in the south, the domestic As emissions in the north or As emissions close to Finnish borders might have decreased.

The implementation of environmental strategies to reduce the lead emissions of traffic through the use of low-leaded and unleaded gasoline succeeded to lower the atmospheric lead pollution in Europe and Northern America during the 1980s and mid-1990s (e.g. Pacyna and Pacyna, 2001). The same reduction has been seen in Finland during the same period of time (Kulmala et al., 1998). Since the early 1990's, lead has not been added to petrol in Finland and many western European countries. During the studied years, $\mathrm{Pb}$ deposition continued to decrease significantly at three stations. During 1998-2005, the European $\mathrm{Pb}$ emissions have declined by over $50 \%$ while the domestic emissions have remained nearly the same (Ilyin et al., 2007; SYKE, 2008). Approximately $30 \%$ of the anthropogenic $\mathrm{Pb}$ deposition in Finland is from domestic sources while the rest originates from transboundary transport from European sources (Ilyin et al., 2007). However, wind resuspension outweighs the sum of European anthropogenic sources and non-EMEP sources including both natural and anthropogenic (Ilyin et al., 2007). The reduction in annual deposition has been more obvious in Northern Finland than in the south. In densely populated and industrialised Southern Finland, the local steady domestic emissions and re-suspension mask the strong decrease of long-range transported lead.

\subsection{2. $\mathrm{Cr}$, $\mathrm{Cu}$ and $\mathrm{Fe}$}

$\mathrm{Cr}$, Cu and Fe deposition increased substantially at some of the stations. This can only be partly explained by emission increase in Finland. According to SYKE (2008), the domestic emissions of $\mathrm{Cu}$ have slightly increased while $\mathrm{Cr}$ emissions first increased and then, after 2002, decreased during a time period of 1998-2006. The Fe emissions are not reported in any of the emission inventories of UNECE/EMEP, ESPREME or EPER (EPER, 2008).

In addition to the domestic emission decrease as reported by the national emission database of SYKE (2008), the ESPREME emission scenarios (2008) also suggest that the chromium emissions in Finland shall decrease by $19 \%$ from the reference year 2000 to the BAU (business as usual) year 2010. On the other hand, ESPREME emission scenarios (2008) predict an increase in $\mathrm{Cr}$ emissions in some of the nearby countries from 2000 to 2010. These countries are Belarus, Latvia, Lithuania and Russian Federation, and they are claimed to have an emission increase of $49,2,45$ and $2 \%$, 
respectively. Still, this emission increase in the abovementioned countries does not entirely explain the upward trend in $\mathrm{Cr}$ deposition seen at the Finnish background stations. Also, the large $\mathrm{Cr}$ emitters Poland and Ukraine, will have a decreasing trend in their emissions according to ESPREME (2008). Nevertheless, the Cr deposition has increased substantially at most stations. At the marine station Hailuoto, the increase has been fourfold. This might be partly due to agricultural activities nearby the station. Since the median EF value for the station is 10 as presented earlier in Fig. 4, the crustal-component as a source is present, but other sources are becoming dominant. The ferrochromium plant in Tornio, which is responsible for the largest $\mathrm{Cr}$ emissions in Finland, is located less than $100 \mathrm{~km}$ north-northwest of Hailuoto. Additionally, the largest chromium mine in the European Union (Kemi Mine) is located close to the ferrochromium plant. The mine practised strip mining until 2005 when new underground mining practises were taken into use. Indeed, in the last 2 years of the survey period (2006 and 2007), the $\mathrm{Cr}$ deposition at Hailuoto decreased considerably, though it had been steadily increasing during the eight previous years. Poikolainen et al. (2004) also found elevated Cr concentrations in mosses in SW Lapland and the highest concentrations in Finland were in the Kemi-Tornio area. It is assumed that the vast increase in $\mathrm{Cr}$ deposition at Hailuoto is mainly (and at Kuusamo $240 \mathrm{~km}$ east of Tornio partly) due to these domestic emissions while the increase at the southern stations is attributable to long-range transport in the lack of local emission sources and possibly windblown dust. The EF's for other stations with significant trends are 4, 6 and 14 (Virolahti, Kotinen and Kuusamo, respectively).

At the turn of millennium, the $\mathrm{Cu}$ deposition was actually decreasing or staying at the same level, and the increase did not start until 2003 with a sudden peak. The peak value in 2003 is most likely affected not only by anthropogenic activities but also by the small rain amount that year resulting in substantial dry deposition of $\mathrm{Cu}$. The subsequent increase in $\mathrm{Cu}$ deposition is alleged to originate from anthropogenic emissions, which are a major source of $\mathrm{Cu}$ as supported by the high EF values of 50-500. In addition to the domestic $\mathrm{Cu}$ emission increase, emissions have slightly increased in the near-by countries such as Germany (UNECE/EMEP, 2008). For $\mathrm{Cu}$ deposition, local anthropogenic sources are dominant and long-range transport is a weaker source in Finland and elsewhere in Scandinavia (Berg et al., 1995; Steinnes et al., 1997; Poikolainen et al., 2004). However, the most significant $\mathrm{Cu}$ emission source areas within or closely outside Finnish borders (Harjavalta-Pori area in SW Finland and NE Lapland; Poikolainen et al., 2004) are closest to those two stations with no significant deposition changes.

Re-suspension is an important source for many elements including iron in the air. To exclude the effect of dust, the deposition trends of the winter months (December, January, February and March as a sum) were calculated. During that time, the ground is mostly covered by snow in Finland and resuspension is insignificant. For these data, the trend remained positive at all the stations although the significance of the trends changed. Now, most of the central and northern stations have a significant upward trend. This provides evidence that the increasing annual trend observed for Fe is real. This is in line with the results from Harmens et al. (2007) who report an overall increase in Fe concentration in mosses in Europe in 1995-2000.

\subsubsection{Other elements}

Aluminium deposition showed a significant decrease at almost half of the stations. When the trend was calculated for winter months only (as for $\mathrm{Fe}$ ), the trend changed. In this case, the only significant change was seen at the southern Virolahti station $(P<0.05$, decreasing). There have been no significant changes in the length of the snow cover period at any of the stations during the studied years.

No trends were detected for $\mathrm{Cd}, \mathrm{Mn}, \mathrm{Ni}, \mathrm{V}$ and $\mathrm{Zn}$ deposition. The domestic emissions of $\mathrm{Cd}$ and $\mathrm{Ni}$ have remained about the same during 1998-2006 while there has been a slight increase in $\mathrm{V}$ and an obvious increase in $\mathrm{Zn}$ emissions (SYKE, 2008). In Europe, the large Cd emitters, Poland and the Russian Federation, have had opposite emission trends (UNECE/EMEP, 2008). In Poland, the emissions are decreasing while in Russia they have been increasing. For major Ni emitters, the same database shows an emission decrease in Poland and France while the German emissions have remained about the same and no information of Russian Federation was provided. The $\mathrm{Zn}$ emissions have increased in Germany, but there has been a substantial decrease in e.g. Poland and France. ESPREME (2008) assessed a 20\% decrease for $\mathrm{Cd}$ and $\mathrm{Ni}$ in Europe from the reference year 2000 to BAU year 2010 but does not discuss Zn.

\subsection{Data validation and measurement uncertainty}

The measurement uncertainty (MU) calculations are based on 9 years of data (1998-2006) from the southern Virolahti station. The applicability of the results was also tested for other stations and found to be consistent. In 1998-2001, there were three identical bulk samplers at the site and from 2002 onward two bulk samplers. As the bulk samplers are open at all times, the samples are also affected by dry deposition. A carefully located sampling site reduces dry deposition caused by resuspension from the ground, but impaction and gravitational settling of particulates during dry periods increases the role of dry deposition in monthly samples. Occasional dry deposition

Table 4- The expanded measurement uncertainties for trace elements measured in precipitation

\begin{tabular}{lcccl} 
Element & $\begin{array}{c}\text { Expanded } \\
\text { measurement } \\
\text { uncertainty } \\
\mathrm{U}_{(p)}\end{array}$ & $\begin{array}{c}\text { Number of } \\
\text { parallel } \\
\text { samples N }\end{array}$ & $\begin{array}{c}\text { Number of } \\
\text { months } \\
\text { LOD }\end{array}$ & $\begin{array}{c}\text { LOD } \\
\left(\mu \mathrm{g} \mathrm{L}^{-1}\right)\end{array}$ \\
\hline $\mathrm{Cd}$ & $21 \%$ & 104 & - & \\
$\mathrm{Mn}$ & $21 \%$ & 104 & - & 0.002 \\
$\mathrm{~Pb}$ & $20 \%$ & 104 & - & 0.005 \\
$\mathrm{~V}$ & $17 \%$ & 104 & - & 0.03 \\
$\mathrm{Al}$ & $34 \%$ & 102 & - & 0.4 \\
$\mathrm{As}$ & $27 \%$ & 99 & 3 & 0.006 \\
$\mathrm{Fe}$ & $43 \%$ & 101 & - & 1.5 \\
$\mathrm{Zn}$ & $44 \%$ & 101 & - & 0.03 \\
$\mathrm{Cr}$ & $52 \%$ & 88 & 11 & 0.02 \\
$\mathrm{Cu}$ & $59 \%$ & 100 & 1 & 0.05 \\
$\mathrm{Ni}$ & $70 \%$ & 95 & 2 & 0.02 \\
\hline
\end{tabular}


is most probably the main reason for large deviations in parallel samples.

During the studied period, no essential changes were made in monitoring of trace elements concerning the sampling equipment, sampling procedure, sample preparation, analysis method and internal quality assurance, thus comprising optimum homogeneity of the database for trend analysis. The same analytical limits of detections (LOD) were also valid during the whole experiment and few samples were below the LOD (Table 4). The measured raw data was validated prior to use in trend analysis. Only a few data were rejected after careful consideration. Typical cases for data rejection were the element concentration deviation in parallel samplers more than tenfold and when the sample information records supported rejection e.g., there were soil derived particulates in the atmosphere due to agricultural activities. The lower concentration sample was used in trend analysis, but for MU calculations data from single measurements could not be used.

The database for evaluation of MU consists theoretically of 108 months. Due to various reasons (no parallel results, no precipitation, analyte concentration below LOD) the number of parallel samples is less than the theoretical maximum. In addition, the Eq. (6) as given in Section 2.6 is sensitive to high concentrations. The square of the absolute concentration difference in Eq. (7) (Section 2.6) becomes high in case of exceptionally high concentration although the parallel results are even. This can easily result in overestimation of the expanded MU by giving too much weight to a single high concentration sample when compared to low concentration samples in the same data set. Therefore, to avoid distortion in estimation of $\mathrm{MU}$, a few high element concentrations were not used.

The expanded measurement uncertainties for the eleven trace elements in precipitation were estimated using Eq. (6) (Section 2.6) and are presented in Table 4. The Cd, Pb, V and Mn concentrations in parallel samplers were even. Based on all measured data the expanded measurement uncertainties for $\mathrm{Cd}, \mathrm{Pb}, \mathrm{V}$, and $\mathrm{Mn}$ were around $20 \%$, for $\mathrm{As}$ and $\mathrm{Al}$ around $30 \%$, and for Fe and $\mathrm{Zn}$ about $40 \%$. The measurement uncertainties for $\mathrm{Cr}$ and $\mathrm{Cu}$ were 50-60\%. Common for both chromium and copper is the concentration deviation in parallel samples throughout the whole data set. Still, the concentrations in

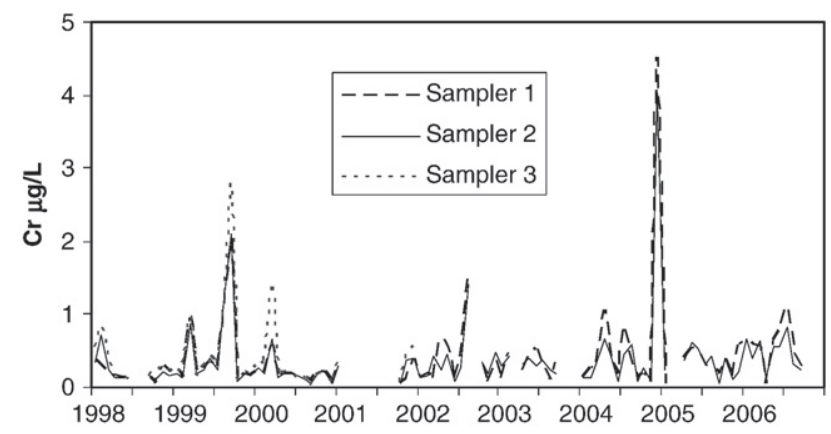

Fig. 5-The concentrations of $\mathrm{Cr}$ in Virolahti in parallel samplers. Dry periods and results below the limit of detection are omitted from the data set. parallel samples are practically even as shown in Fig. 5 for chromium.

The highest expanded measurement uncertainty of the studied eleven trace elements was found for $\mathrm{Ni}$ being approximately $70 \%$. In nearly one fifth of the parallel sample data the concentration of one sample was at least twofold when compared with the other sample. Nickel is known to exist in fine particles, and thus, dry deposition might be of great importance as has been observed in e.g. Japan (Sakata et al., 2006). In this article, only those cases were rejected when the parallel sample concentrations differed tenfold.

The laboratory has participated regularly in EMEP's and WMO/GAW's analytical intercomparisons where the average relative error for trace elements in precipitation samples has settled between $\pm 7 \%$ and $\pm 9 \%$ (in total 34 intercomparison samples). Thus, the measurement uncertainty of the whole measurement chain is mostly affected by the non-homogeneity of the samples rather than the uncertainty of the analysis method.

\section{Conclusions}

In this survey, we have presented the deposition data for 11 trace elements ( $\mathrm{Al}, \mathrm{As}, \mathrm{Cd}, \mathrm{Cr}, \mathrm{Cu}, \mathrm{Fe}, \mathrm{Mn}, \mathrm{Ni}, \mathrm{Pb}, \mathrm{V}$ and $\mathrm{Zn}$ ), discussed about the origin of the elements through the use of enrichment factors and calculated the temporal trends of the elements. We have also estimated the expanded measurement uncertainty, which includes not only the analytical step but also the sample collection part. The data analysed is from eight background stations around Finland during the last 10 years (1998-2007).

The annual deposition of the trace elements ranged from $40 \mu \mathrm{g} \mathrm{m}^{-2}$ for Cd to $51,000 \mu \mathrm{g} \mathrm{m}^{-2}$ for Fe in Southern Finland in 2007. During the whole study period, the annual deposition order was $\mathrm{Cd}<\mathrm{As}<\mathrm{Cr}<\mathrm{Ni}<\mathrm{V}<\mathrm{Cu}$ and $\mathrm{Pb}<\mathrm{Mn}<\mathrm{Zn}<\mathrm{Al}<\mathrm{Fe}$ also expressing a clear decreasing south-to-north gradient for most elements. This is typically due to minor domestic emissions in the north and longer distance to the large European source areas than in the south. Additionally, differences in the length of snow-cover period have an effect on re-suspension of some elements. Element enrichment factors indicated that $\mathrm{Cr}, \mathrm{Fe}$ and $\mathrm{Mn}$ are mostly of crustal origin, while $\mathrm{Cu}, \mathrm{Ni}, \mathrm{V}$ and especially $\mathrm{As}, \mathrm{Cd}, \mathrm{Pb}$ and $\mathrm{Zn}$ are strongly of anthropogenic origin.

The nonparametric Mann-Kendall test used for trend analysis showed that $\mathrm{As}$ and $\mathrm{Pb}$ deposition have continued to decrease at the current decade following the emission decrease estimated by ESPREME (2008). However, $\mathrm{Cr}, \mathrm{Cu}$ and Fe depositions have recently increased, while no statistically significant trends were detected for $\mathrm{Cd}, \mathrm{Mn}, \mathrm{Ni}, \mathrm{V}$ and $\mathrm{Zn}$ during the studied years. The expanded measurement uncertainties of $\mathrm{Cd}, \mathrm{Pb}, \mathrm{V}, \mathrm{Mn}, \mathrm{As}, \mathrm{Al}$, Fe and $\mathrm{Zn}$ were good and for $\mathrm{Cr}$ and $\mathrm{Cu}$ reasonable for trend analysis. The expanded measurement uncertainty for $\mathrm{Ni}$ is much higher than for the other studied elements, which may cover minor changes in trends.

The majority of trace element deposition in Finland is due to long-range atmospheric transport. Meteorological factors which interact with the air transport routes and the European emission fields contribute most to deposition and changes in 
it. The estimated increase in rainfall amounts in Finland within the changing climate will probably increase wet deposition of trace elements. The shorter snow period might increase the re-suspension of the trace elements back to the atmosphere. This will increase both dry and wet deposition. In the future, dissection of the trace element concentrations and trends at the northern station of Pallas is planned. Studies of present changes in trace element deposition and airborne concentrations are truly needed in other, and moreover, in larger areas in Europe to assess the effects of emission changes and the predicted reductions in the current decade.

\section{Appendix A. Supplementary data}

Supplementary data associated with this article can be found, in the online version, at doi:10.1016/j.scitotenv.2008.11.045.

\section{R E F E R E N C E S}

Berg T, Royset O, Steinnes E, Vadset M. Atmospheric trace element deposition: principal component analysis of ICP-MS data from moss samples. Environ Pollut 1995;88:67-77.

EMEP/CCC. Manual for sampling and chemical analysis. Revised November 2001. Kjeller: Norwegian Institute for Air Research; 2001 (EMEP/CCC-Report 1/95); URL: http://www.nilu.no/projects/ $\mathrm{ccc} /$ manual/index.html (Aug, 2008).

EPER. European Pollutant Emission Register - Database for Pollutants. URL:http://eper.ec.europa.eu/eper/emissions_ pollutants.asp?i=(Apr, 2008)2008.

ESPREME. National Emission Inventories. URL:http://espreme.ier. uni-stuttgart.de/2008 (May, 2008).

EU. Council Directive 1999/30/EC of 22 April 1999 relating to limit values for sulphur dioxide, nitrogen dioxide and oxides of nitrogen, particulate matter and lead in ambient air. Off J 1999; L 163:41-60 29/06/, URL: http://eur-lex.europa.eu/LexUriServ/ LexUriServ.do?uri=CELEX:31999L0030:EN:HTML (Aug, 2008).

EU. Directive 2004/107/EC of the European Parliament and of the Council of 15 December 2004 relating to arsenic, cadmium, mercury, nickel and polycyclic aromatic hydrocarbons in ambient air. Off J 2005;L 23:3-16 26/1/, URL: http://eur-lex. europa.eu/LexUriServ/LexUriServ.do?uri=OJ: L:2005:023:0003:0016:EN:PDF (Aug, 2008).

Foltescu VL, Isakson J, Selin E, Stikans M. Measured fluxes of sulphur, chlorine and some anthropogenic metals to the Swedish west coast. Atmos Environ 1994;28:2639-49.

Galloway JN, Thornton JD, Norton SA, Volchok HL, McLean RAN. Trace metals in atmospheric deposition: a review and assessment. Atmos Environ 1982;16:1677-700.

Gilbert RO. Statistical methods for environmental pollution monitoring. New York: Van Norstrand Reinhold; 1987. 320 pp.

Harmens H, Norris D, Koerber G, Buse A, Steinnes E, Rühling Å. Temporal trends in the concentration of arsenic, chromium, copper, iron, nickel, vanadium and zinc in mosses across Europe between 1990 and 2000. Atmos Environ 2007;41:6673-87.

Harmens H, Norris D, Koerber G, Buse A, Steinnes E, Rühling Å. Temporal trends in the concentration of cadmium, lead and mercury in mosses across Europe. Environ Pollut 2008;151 (2):368-76.

Hjellbrekke AG. EMEP Data Report 1998 part 1: annual summaries, EMEP/CCC-Report 3/2000; 2000.

Ilyin I, Rozovskaya O, Travnikov O, Aas W. EMEP Status report 2/2007. Heavy metals: trans-boundary pollution of the environment; 2007.

ISO Air Quality — Guidelines for estimating measurement uncertainty. ISO 20988:2007; 2007.

Jaffe D, Cerundolo B, Rickers J, Stolzberg R, Baklanov A. Deposition of sulfate and heavy metals on the Kola Peninsula. Sci Total Environ 1995;160-161:127-34.

Kubin E, Lippo H. Atmospheric heavy metal deposition in Finland from 1985 to 1990. Appl Geochem 1996;11:155-61.

Kulmala A, Leinonen L, Ruoho-Airola T, Salmi T, Waldén J. Air quality trends in Finland. Air Qual Meas 199891 pp. ISSN 1235-8843, ISBN 951-697-488-0.

Mason B. Principles of geochemistry. New York: John Wiley \& Sons Inc.; 1966. 329 pp.

Matschullat J, Maenhaut W, Zimmermann F, Fiebig J. Aerosol and bulk deposition trends in the 1990's, Eastern Erzgebirge, Central Europe. Atmos Environ 2000;34:3213-21.

Pacyna J. Workpackage 02 - D01b source-sector analysis and evaluation report. Estimation of willingness-to-pay to reduce risks of exposure to heavy metals and cost-benefit analysis for reducing heavy metals occurrence in Europe; 2007. URL: http:// espreme.ier.uni-stuttgart.de/ (Apr, 2008).

Pacyna JM, Pacyna EG. An assessment of global and regional emissions of trace metals to the atmosphere from anthropogenic sources worldwide. Environ Rev 2001;9:269-98.

Peirson DH, Cawse PA, Salmon L, Cambray RS. Trace elements in the atmospheric environment. Nature 1973;241:252-6.

Poikolainen J, Kubin E, Piispanen J, Karhu J. Atmospheric heavy metal deposition in Finland during 1985-2000 using mosses as bioindicators. Sci Total Environ 2004;318:171-85.

Rühling A, Tyler G. Changes in atmospheric deposition rates of heavy metals in Sweden - a summary of nationwide Swedish surveys in 1968/70-1995. Water Air Soil Pollut: Focus 2001;1:311-23.

Ruoho-Airola T, Anttila P, Salmi T. Airborne sulfur and nitrogen in Finland-trends and exposure in relation to air transport sector. J Environ Monit 2004;6:1-11.

Sakata M, Marumoto K, Narukawa M, Asakura K. Regional variations in wet and dry deposition fluxes of trace elements in Japan. Atmos Environ 2006;40:521-31.

Salmi T, Määttä A, Anttila P, Ruoho-Airola T, Amnell T. Detecting trends of annual values of atmospheric pollutants by the Mann-Kendall test and Sen's slope estimates - the Excel template application MAKESENS. Publications on air quality, vol. 31. 951-697-563-1; 2002. 35 pp. Report Code FMI-AQ-31.

Steinnes E, Allen RO, Petersen HM, Rambaek JP, Varskog P. Evidence of large scale heavy-metal contamination of natural surface soils in Norway from long-range atmospheric transport. Sci Total Environ 1997;205:255-66.

SYKE. Air pollutant emissions in Finland. URL:www.environment. fi 2008 (April, 2008).

UNECE/EMEP. UNECE/EMEP emission database WebDab — officially reported data, present state of emission data. URL:http://www. emep-emissions.at/emission-data-webdab/2008 (July, 2008).

Wiersma GB, Davidson CI. Trace metals in the atmosphere of remote areas. In: Nriagu JO, Davidson CI, editors. Toxic metals in the atmosphere. New York: John Wiley \& Sons Inc.0-471-82654-5; 1986. p. 201-66. 



\title{
Temporal trends in the bulk deposition and atmospheric concentration of acidifying compounds and trace elements in the Finnish Integrated Monitoring catchment Valkea-Kotinen during 1988-2011
}

\author{
Tuija Ruoho-Airola1), Tarja Hatakka²), Katriina Kyllönen'1), Ulla Makkonen'1) \\ and Petri Porvari3) \\ 1) Finnish Meteorological Institute, P.O. Box 503, Fl-00101 Helsinki, Finland \\ 2) Geological Survey of Finland, P.O. Box 96, Fl-02151 Espoo, Finland \\ 3) Finnish Environment Institute, P.O. Box 140, Fl-00251 Helsinki, Finland
}

Received 30 Nov. 2012, final version received 28 Mar. 2013, accepted 3 Apr. 2013

\begin{abstract}
Ruoho-Airola, T., Hatakka, T., Kyllönen, K., Makkonen, U. \& Porvari, P. 2014: Temporal trends in the bulk deposition and atmospheric concentration of acidifying compounds and trace elements in the Finnish Integrated Monitoring catchment Valkea-Kotinen during 1988-2011. Boreal Env. Res. 19 (suppl. A): 31-46.
\end{abstract}

The precipitation chemistry of nearly 30 acidifying compounds, base cations and several trace elements was monitored in the Valkea-Kotinen catchment in southern Finland during 1988-2011. Measurements of the atmospheric concentration of $\mathrm{SO}_{2}, \mathrm{NO}_{2}$ and $\mathrm{O}_{3}$ covered a shorter period. Temporal trends in the components are presented. A notable finding was an indication of a possible increase in the bulk deposition of $\mathrm{Cd}$ and $\mathrm{NO}_{3}^{-}$. The effect of the changing nitrate deposition on the hydrological continuum of groundwater is also briefly discussed. The transport of air masses to the Valkea-Kotinen catchment was estimated and binds all the results presented in this issue to the development in the emission patterns in Europe.

\section{Introduction}

The Integrated Monitoring (IM) Programme is one of the five International Co-operative Programmes carried out under the Convention on Long-Range Transboundary Air Pollution. The aim of the programme is to investigate the influence of transboundary atmospheric deposition on natural ecosystems (Bergström et al. 1995). Extensive monitoring of atmospheric deposition is essential for the successful fulfilment of the IM programme and reflects the development in Finnish and European emission patterns.

Results from the first five (Bergström et al. 1995) and ten (Ruoho-Airola et al. 1998, Ukon- maanaho et al. 1998) years of atmospheric deposition monitoring at the Finnish IM stations have been published earlier. Measurements of the atmospheric load now cover 24 years for acidifying compounds, 8-17 years for gaseous compounds and 9-22 years for trace elements. This homogeneous and continuous set of high quality data has enabled us to update existing knowledge of the level and trends in the time series of atmospheric compounds at Valkea-Kotinen, southern Finland. These results have been further used in IM studies on ecosystem effects. In addition, analysis of the uniquely long time series of trace elements is of general interest in relation to the development of the atmospheric 
load in Finland, as well as in examining the relationships between reported European emission reductions and the air concentrations and depositions in relatively remote parts of northern Europe.

Vuorenmaa et al. (2009) assessed the deposition data covering 1993-2006 from 33 ICP IM sites in Europe, and the results of monitoring at the four Swedish Integrated Monitoring sites during 1996-2009 have been published in a special issue of Ambio. Sulphate $\left(\mathrm{SO}_{4}{ }^{2-}\right)$ deposition decreased, whereas no significant change was found in Sweden for nitrate $\left(\mathrm{NO}_{3}^{-}\right)$, chloride $\left(\mathrm{Cl}^{-}\right)$ or the base cations (Löfgren et al. 2011). In the European Monitoring and Evaluation Programme (EMEP), concentrations and depositions of major atmospheric contaminants have been monitored in a network presently covering most parts of Europe. Results of the monitoring from 1980 2000 have been assessed by Lövblad et al. (2004) and from 1972-2009 by Tørseth et al. (2012). A large decline was detected in the concentration and deposition of sulphur compounds throughout Europe, but only a moderate decline in nitrogen compounds (Lövblad et al. 2004, Tørseth et al. 2012). Input/output budgets for the most important trace elements have been determined for 14 ICP IM sites, including Valkea-Kotinen, showing high retention in catchments (Bringmark et al. 2013). In the EMEP data, the downward trend for the deposition of the trace elements lead $(\mathrm{Pb})$, cadmium $(\mathrm{Cd})$ and mercury $(\mathrm{Hg})$ has levelled off in recent years (Tørseth et al. 2012).

This paper aims to present the atmospheric bulk depositions of the main ions affecting acidification and also of trace elements, as well as gaseous compounds measured at Valkea-Kotinen, and to provide an overview of the development in the time series. In particular, $\mathrm{NO}_{3}^{-}$deposition is discussed. The trends in air concentrations and depositions are discussed in relation to trends in European emission reductions.

\section{Methods}

A description of the physico-chemical and ecological status, and characteristics of the ValkeaKotinen catchment site has been published in the five-year report of the monitoring programme by Bergström et al. (1995). Site analysis of the Valkea-Kotinen measuring station relative to air pollution emission sources on the mesoscale (from tens of kilometres to about one hundred kilometres) has been compiled in Ruoho-Airola et al. (1998), a paper included in a special issue presenting the Finnish IM results. Here, we present a summary of the methods used in the subprogrammes for precipitation, air and groundwater chemistry, as well as methods for trend calculation and sectoral analysis. A detailed description of the methods for monitoring is presented in the Manual of Integrated Monitoring (ICP IM Programme Centre 1998).

The contents of the different subprogrammes covered in this study and the institutions responsible for the monitoring are listed in Table 1. The precipitation chemistry subprogramme has been carried out continuously at the ValkeaKotinen catchment since the beginning of the IM programme in 1987. Initially, the measurement programme covered the main anions and cations that have an impact on the atmospheric acidification of ecosystems. Later, deposition measurements of trace elements as well as air chemistry monitoring were gradually added to the programme. Meteorological measurements at meteorological stations near the Valkea-Kotinen catchment cover the whole monitoring period.

\section{Sampling and analysis of the precipitation and air chemistry programmes}

Measurements of the main anions and cations in precipitation were started in Valkea-Kotinen in April 1987. The site for the sampling of precipitation as well as sulphur dioxide $\left(\mathrm{SO}_{2}\right)$ and nitrogen dioxide $\left(\mathrm{NO}_{2}\right)$ was an open area in peatland forest about $75 \mathrm{~m}$ in diameter. The angle to the nearest trees was below $30^{\circ}$ from the rim of the precipitation collector. The sampling height was $1.5 \mathrm{~m}$ above the ground level. Lake Valkea-Kotinen is located about $150 \mathrm{~m}$ to the north of the sampling site. The Valkea-Kotinen catchment is a protected area of mainly southern boreal upland forest and peatlands, and no agricultural areas are included in the land use of the catchment (Bergström et al. 1995). 
NILU-type bulk samplers (polyethylene) with an opening of $200 \mathrm{~mm}$ were used for the sampling of precipitation. Because the samplers were always open, part of the dry deposition was included in the samples. The weekly samples were combined after visual checking to give monthly samples. Furthermore, anions and cations were analysed by ion chromatography (EMEP Manual 2001). The fulfilment of the ECE/EMEP Data Quality Objectives (EMEP 2001), i.e. a maximum of $15 \%-25 \%$ uncertainty for the combined sampling and chemical analysis, was tested with the help of three parallel sampling devices in 1988-1995 (Ruoho-Airola and Leinonen 1997).

The sampling of most trace elements in precipitation started in 1990. The trace element samples were collected monthly with similar NILUtype bulk deposition samplers to the samples for main ion analysis. For trace element sampling, the collectors were acid-washed. During the early years of sampling, only one sampler was used. In 1992-2007, two replicate samples were collected, but in 2008, replicate sampling was discontinued again after careful consideration and data investigation. The trace element samples were analysed with graphite furnace atomic absorption spectrometry (GF-AAS) until 1993, and with inductively coupled plasma mass spectrometry (ICP-MS) after 1994. Iron (Fe) and chromium $(\mathrm{Cr})$ continued to be analysed with GF-AAS for one additional year, until 1994. Further details on the analysis method and uncertainties are given in Kyllönen et al. (2009).

The sampling of total mercury $\left(\mathrm{Hg}_{\text {tot }}\right)$ in precipitation (bulk deposition) started in 1995 at Uraani, in the Janakkala research area $\left(61^{\circ} 01^{\prime} \mathrm{N}\right.$, $24^{\circ} 45^{\prime} \mathrm{E}, 31 \mathrm{~km}$ to the southwest from the Valkea-Kotinen IM area). A detailed description of the site is provided in Porvari (2003). In 2005, sampling was relocated to Valkea-Kotinen. For the bulk deposition sampling, two duplicate IVL-type collectors were installed in an opening in the forest. In order to estimate the $\mathrm{Hg}_{\text {tot }}$ concentrations in precipitation for the winter period (December to March), snow samples from an opening in the forest were taken into Teflon ${ }^{\circledR}$ bottles at the end of March. The precipitation amounts were measured at the nearby meteorological station. Since 2010, a single IVL-type collector has been used around the year and the samples have been collected and analysed according to SFS-EN 15853:2010 and SFS-EN ISO 17852:2008 with minor exceptions.

Table 1. Precipitation, air quality, ground water and meteorological measurements in the Valkea-Kotinen Integrated Monitoring area. Responsible institution abbrevaiations: FMI = Finnish Meteorological Institute, FEI = Finnish Environment Institute, GTK = Geological Survey of Finland.

\begin{tabular}{|c|c|c|c|c|c|}
\hline Subprogramme & $\begin{array}{l}\text { Responsible } \\
\text { institution }\end{array}$ & $\begin{array}{l}\text { Frequency of } \\
\text { sampling }\end{array}$ & $\begin{array}{l}\text { Components } \\
\text { measured }\end{array}$ & $\begin{array}{l}\text { Start of } \\
\text { sampling }\end{array}$ & $\begin{array}{l}\text { End of } \\
\text { sampling }\end{array}$ \\
\hline \multirow[t]{6}{*}{ Precipitation chemistry } & FMI & 1 month & $\begin{array}{l}\mathrm{H}^{+}, \mathrm{Cl}, \mathrm{NO}_{3}, \mathrm{SO}_{4}, \mathrm{NH}_{4}, \\
\mathrm{Mg}, \mathrm{Ca}, \mathrm{Na}, \mathrm{K}\end{array}$ & 1.IV.1987 & \\
\hline & FMI & 1 month & $\begin{array}{l}\mathrm{Zn}, \mathrm{Pb}, \mathrm{Cu}, \mathrm{Cd}, \mathrm{Cr} \\
\mathrm{Fe}, \mathrm{Mn}, \mathrm{V}\end{array}$ & 1.VI.1990 & \\
\hline & FMI & 1 month & $\mathrm{Ni}, \mathrm{As}$ & 1.I.1990 & \\
\hline & FMI & 1 month & Al, Co & 1.I.2003 & \\
\hline & FEI & 1 month & $\mathrm{Hg}^{\star}$ & 1.VII.1994 & XII.2009 \\
\hline & FMI & 1 month & $\mathrm{Hg}$ & 1.IX.2009 & \\
\hline \multirow[t]{3}{*}{ Air chemistry } & FMI & 1 month & $\mathrm{SO}_{2}$ & 1.I.1996 & 31.XII.2003 \\
\hline & FMI & 1 month & $\mathrm{NO}_{2}$ & 1.I.1996 & 31.XII.2007 \\
\hline & FMI & 1 hour & $\mathrm{O}_{3}$ & 30.XI.1994 & \\
\hline Meteorology & FMI & $1-24$ hours & $\begin{array}{l}\text { precipitation, temperature, } \\
\text { humidity, wind velocity and } \\
\text { direction, UV radiation }\end{array}$ & 1.IV.1987 & \\
\hline Groundwater chemistry & GTK & 3 months & $\begin{array}{l}\mathrm{pH}, \mathrm{H}^{+}, \mathrm{Cl}, \mathrm{NO}_{3}, \mathrm{SO}_{4}, \mathrm{Mg}, \\
\mathrm{Ca}, \mathrm{Na}, \mathrm{K}, \mathrm{HCO}_{3} \text {, alkalinity }\end{array}$ & & \\
\hline
\end{tabular}

\footnotetext{
* Sampling from 1994-2004 in the Janakkala research area, approximately $30 \mathrm{~km}$ from Evo.
} 
Concentrations of $\mathrm{SO}_{2}$ and $\mathrm{NO}_{2}$ were measured with IVL-type diffusion samplers (Ferm 1991). Monthly samples were collected using two parallel samplers and field blanks were subtracted from the results. In the sampler, $\mathrm{SO}_{2}$ was trapped on Whatman 40 filter paper ( $\varnothing 25 \mathrm{~mm}$ ) impregnated with $1 \% \mathrm{NaOH}$ (in methanol). To collect $\mathrm{NO}_{2}$, similar Whatman filters were treated with a solution containing $9 \% \mathrm{NaI}$ and $1 \% \mathrm{NaOH}$. After exposure, the sample filters were extracted in HPLC-grade water. The $\mathrm{SO}_{2}$ filter extracts were filtered and analysed for $\mathrm{SO}_{4}^{2-}$ by ion chromatography (Waters). The $\mathrm{NO}_{2}$ filter extracts were analysed colorimetrically at $540 \mathrm{~nm}$ for nitrite, after mixing with a diazotizing reagent (EMEP 2001). Ozone $\left(\mathrm{O}_{3}\right)$ was monitored $4 \mathrm{~km}$ to the southeast of Valkea-Kotinen by UV photometry. The calibration of the monitor is traceable to the Finnish reference at the national reference laboratory on air quality (www.fmi.fi).

The Geological Survey of Finland (GTK) has monitored groundwater quality in southern Finland since 1969 (Backman et al. 1999). Water quality was investigated from 1974 to 2010 at Kellolähde near the Valkea-Kotinen catchment $\left(61^{\circ} 00^{\prime} \mathrm{N}, 25^{\circ} 12^{\prime} \mathrm{E}, 27 \mathrm{~km}\right.$ to south from the Valkea-Kotinen IM area). Before 1995, the groundwater samples were taken six times per year, and after this four times per year. The Kukonharju-Sipilänharju sand and gravel formation is a large groundwater reservoir, and groundwater discharges into the Kellolähde spring, which is in a natural condition (Backman et al. 1999, Backman 2004). $\mathrm{NO}_{3}^{-}$concentrations in groundwater were analysed at the geochemical laboratory of GTK (later Labtium Oy) from untreated water samples initially by spectrophotometry and from 1989 by ion chromatography (Backman et al. 1999).

\section{Trend analysis}

A generalized least-squares (GLS) regression with classical decomposition and autoregressive moving average (ARMA) errors used for monthly mean values was carried out using the method of Brockwell and Davies (2002) (ITSM Professional 7.3, B and D Enterprises Inc.). The detailed steps used for the calculation of the seasonal com- ponents by a moving average with a 13-month window, a preliminary regression model for the trend in the deseasonalized data, the iteration of the optimal $\operatorname{ARMA}(p, q)$ model for the residuals and the final estimates for the trend and error structure are described in Anttila and Tuovinen (2009). Further principles of the method are presented in Brockwell and Davies (2002).

\section{Sectoral analysis}

The transport of the air masses to the ValkeaKotinen area was analysed using two-dimensional $925 \mathrm{hPa}$ backward trajectories of $96 \mathrm{~h}$ obtained from the EMEP MSC-W (www.EMEP. int). The air parcel was tracked every $2 \mathrm{~h}$ along modelled wind fields, and the trajectories were calculated four times per day. The area around the arrival point was divided into eight equal sectors. The criterion for the allocation of the trajectories of a particular arrival day to a specific sector was that at least $50 \%$ of their given positions during transport were found within that sector. If this criterion was not fulfilled, the sector for that day was set as undetermined. Finally, the number of days with transport from the corresponding sector was counted. In analysing the differences in transport between seasons, the months from October to March were included in the winter season, and the months from April to September in the summer season. The detailed steps used for the transport analysis are presented in Ruoho-Airola et al. (2004).

\section{Results and discussion}

\section{Acidifying compounds in deposition}

\section{Annual bulk deposition}

The total monitoring period of the main anions and cations covered 24 years. The annual deposition levels of the components were evaluated from 10-year mean values, which filtered away the less interesting short-term variation in the time series. The averaged periods always overlapped by five years: 1988-1997, 1993-2002, 1998-2007 and 2003-2011 (the last period cov- 
Fig. 1. Ten-year annual mean values for the bulk deposition of the main anions and cations at Valkea-Kotinen.

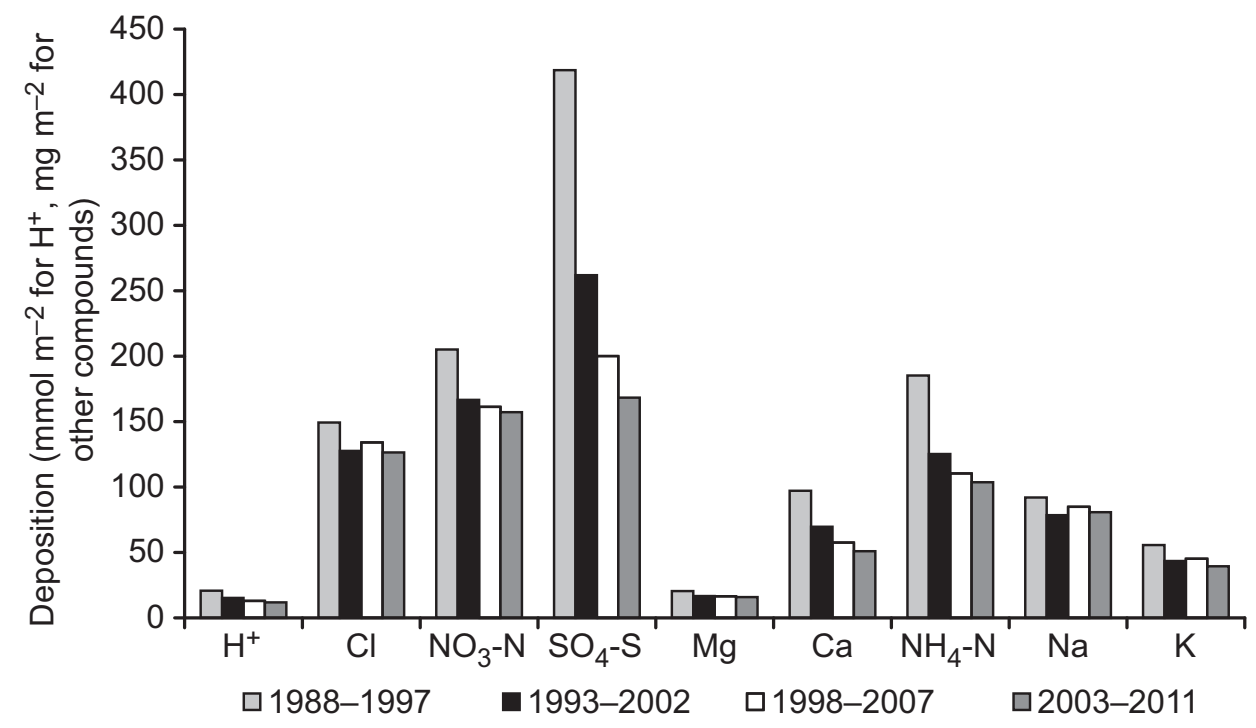

ered only nine years). This procedure enabled changes in the average level of the annual deposition to be followed in five-year steps.

For all the main anions and cations, the deposition was highest during the first period from 1988 to 1997 (Fig. 1). At that time, the mean deposition values for $\mathrm{SO}_{4}{ }^{2-}$, calculated as sulphur (S), and $\mathrm{NO}_{3}^{-}$and $\mathrm{NH}_{4}^{+}$, calculated as nitrogen $(\mathrm{N})$, were 419,205 and $185 \mathrm{mg} \mathrm{m}^{-2}$, respectively. Depositions of $\mathrm{Cl}^{-}$and hydrogen ions $\left(\mathrm{H}^{+}\right)$were $149 \mathrm{mg} \mathrm{m}^{-2}$ and $21 \mathrm{mmol} \mathrm{m}^{-2}$, respectively. Finally, mean depositions of the base cations sodium $\left(\mathrm{Na}^{+}\right)$, potassium $\left(\mathrm{K}^{+}\right)$, calcium $\left(\mathrm{Ca}^{2+}\right)$ and magnesium $\left(\mathrm{Mg}^{2+}\right)$ at the beginning of the monitoring period were 92, 56, 97 and $21 \mathrm{mg} \mathrm{m}^{-2}$, respectively. The deposition levels at Valkea-Kotinen were comparable to results measured at other background stations in southern Finland (Kulmala et al. 1998) and the other Nordic countries (Lövblad et al. 2004, Löfgren et al. 2011, Tørseth et al. 2012).

For $\mathrm{SO}_{4}^{2-}$, the decline from average deposition in 1988-1997 to that in 1993-2002 was considerable, being $35 \%$, which reflected the large decrease in sulphur emissions in Finland and elsewhere in Europe (Lövblad et al. 2004). Similar results have been reported from other monitoring stations in Finland and northern Europe (Lövblad et al. 2004, Tørseth et al. 2012). In addition, mean ammonium deposition declined almost as much during the same period. The majority of the Finnish atmospheric sulphur load results from long-range ammonium-sulphate transport (Nyíri et al. 2010), which explains the parallel decline in these components. $\mathrm{NO}_{3}^{-}$ deposition also declined by almost $20 \%$ during the first half of the monitoring period, partly due to the decrease in nitrogen dioxide emissions in Finland and elsewhere in Europe (Lövblad et al. 2004). The long-range transport accounted for about $90 \%$ of $\mathrm{NO}_{3}^{-}$deposition at Valkea-Kotinen (Nyíri et al. 2010). However, the transport and deposition of $\mathrm{S}, \mathrm{NO}_{3}^{-}$and $\mathrm{NH}_{4}^{+}$are linked through air chemistry (Seinfeld and Pandis 2006), which creates nonlinearities in the changes in deposition as compared with the changes in emissions (Fowler et al. 2005). The decrease in $\mathrm{SO}_{2}$ emissions has led to a shift towards the formation of more ammonium nitrate particles (Fagerli and Aas 2008).

Average depositions of the base cations $\mathrm{Na}^{+}, \mathrm{K}^{+}, \mathrm{Ca}^{2+}$ and $\mathrm{Mg}^{2+}$ declined by $15 \%-30 \%$ between the periods 1988-1997 and 1993-2002. This result is consistent with the decline of $15 \%-35 \%$ in total depositions of the base cations recorded for the whole of Finland between the years 1989 and 2000 (Ruoho-Airola et al. 2003) and in other European countries (Tørseth et al. 2012). The change is considered to have mostly originated from the decline in anthropogenic emissions. The mean deposition of $\mathrm{H}^{+}$, which reflects the changes in all of the acidifying compounds, declined by $25 \%$ between the two first 10 -year periods.

Later, the deposition levels did not change as strongly as at the beginning. During the final 


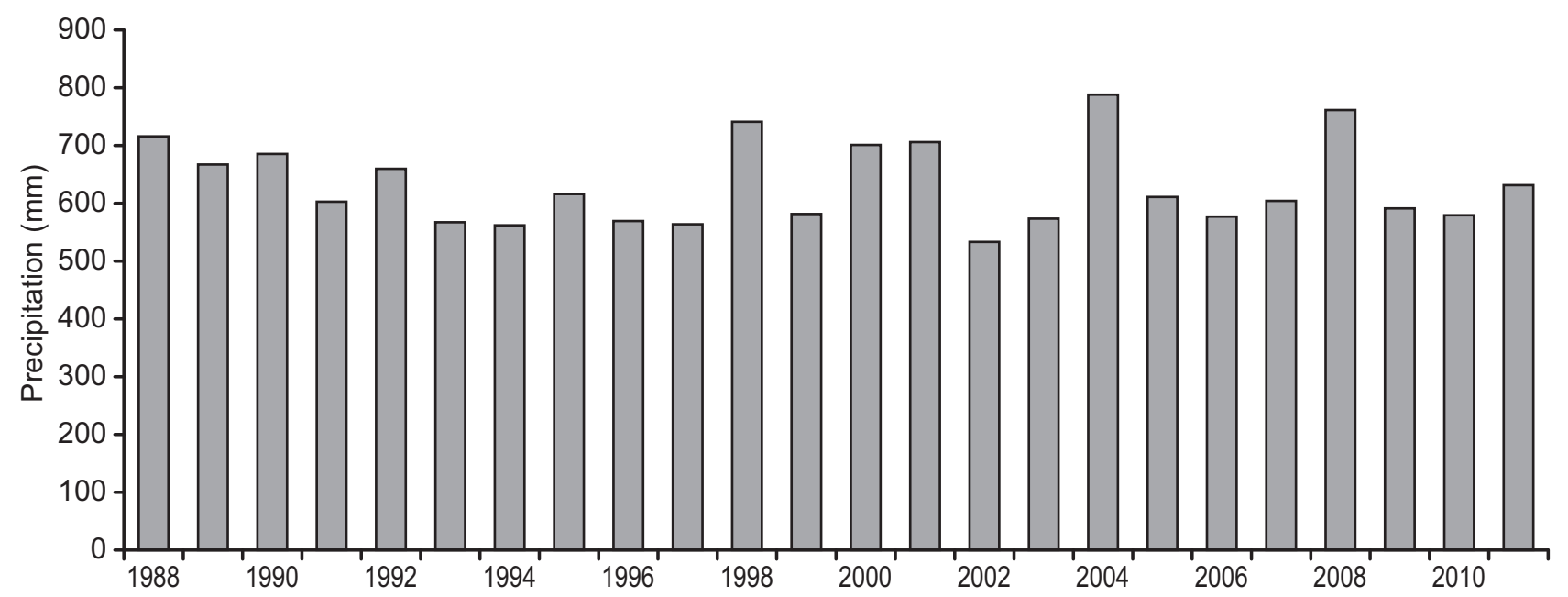

Fig. 2. Annual precipitation at the Lammi Biological Station, near the Valkea-Kotinen monitoring station.

years of the monitoring period, the mean deposition level was $40 \%$ of the level at the beginning for $\mathrm{SO}_{4}^{2-}, 50 \%-60 \%$ for $\mathrm{H}^{+}, \mathrm{NH}_{4}^{+}$and $\mathrm{Ca}^{2+}$ and $70 \%-80 \%$ for $\mathrm{K}^{+}$and $\mathrm{NO}_{3}^{-}$. Deposition of the compounds largely derived from sea spray, i.e. $\mathrm{Cl}^{-}, \mathrm{Na}^{+}$and $\mathrm{Mg}^{2+}$, at the end was $80 \%-90 \%$ of the level at the beginning.

Precipitation at the Lammi Biological Station shows rather large inter-annual variation (Fig. 2). This is the nearest station (see fig. 1 and table 1 in Jylhä et al. 2014) with a continuous time series of precipitation. The highest annual precipitation was $788 \mathrm{~mm}$ in 2004, whereas the minimum precipitation was $533 \mathrm{~mm}$ in 2002 . The level of precipitation strongly affects the calculation of deposition, which is formed by multiplying the concentration of the component in a rainwater sample by the amount of precipitation collected by the sampler. However, a large amount of rain does not necessarily mean a high level of deposition. For example, $\mathrm{SO}_{4}^{2-}$ deposition in Valkea-Kotinen was $167 \mathrm{mg} \mathrm{S} \mathrm{m}^{-2}$ in both 2002 and 2004, showing no direct influence of the minimum or maximum rainfall amount.

\section{Trends in the deposition of acidifying compounds within 10-year periods}

The previous chapter presented the average deposition levels and changes in the levels between 10 -year periods. In order to analyse the pattern of the time series in detail, statistical trend analysis within each of the 10-year periods was performed. Because the ITSM time series analysis used for the calculations can handle the seasonality in the data, the calculations were applied to monthly deposition. The greater number of data points per year also enabled the analysis of shorter time series for $\mathrm{NO}_{3}^{-}$deposition (see the next chapter).

The ITSM analysis was performed for all main ions and all periods, i.e. 1988-1997, 19932002, 1998-2007 and 2003-2011. For the deseasonalized time series, the GLS linear regression and the optimal ARMA structure for the residuals was calculated.

A statistically significant decreasing trend was found for all of the main anions and cations in the period 1988-1997 (Table 2). $\mathrm{SO}_{4}{ }^{2-}$ and $\mathrm{NH}_{4}^{+}$declined equally by $7.5 \%$ per year during this decade, and $\mathrm{Ca}^{2+}$ by almost as much (7\%). All the other compounds declined annually by $4 \%-6 \%$. The annual change in the amount of precipitation was $2 \%$, which might have partly affected the deposition pattern of the chemical components.

In the other periods, only a few significant trends were detected in the time series of the components (Table 2). $\mathrm{SO}_{4}^{2-}$ declined in all 10-year periods, but the value of the slope decreased with time. $\mathrm{H}^{+}$deposition likewise decreased through the whole time series, reflecting the strongly acidifying effect of sulphate deposition. In addition to these changes, $\mathrm{NH}_{4}^{+}$ and $\mathrm{Ca}^{2+}$ deposition declined during 1998-2007 and $\mathrm{Mg}^{2+}$ during 2003-2011. 
Trends in the deposition of $\mathrm{SO}_{4}^{2-}, \mathrm{NO}_{3}^{-}$, $\mathrm{H}^{+}$and $\left(\mathrm{Ca}^{2+}+\mathrm{Mg}^{2+}\right)$ at $33 \mathrm{IM}$ sites in Europe was calculated for 1995-2006 by Vuorenmaa et al. (2009). In Sweden, Norway and the Baltic countries, the development in the deposition was fairly similar to the pattern at Valkea-Kotinen: $\mathrm{SO}_{4}{ }^{2-}$ and $\mathrm{H}^{+}$widely decreased, whereas for depositions of $\mathrm{NO}_{3}^{-}$and base cations only a few significant downward trends were detected.

\section{Detailed analysis of nitrate deposition and nitrate changes in ground water}

Nitrate deposition was further analysed with the ITSM programme because of the possible increase in deposition. Between 1988 and 1990, $\mathrm{NO}_{3}^{-}$deposition declined steeply, the annual change being $-17 \%$ (Table 3). During the next years, from 1991 to 1997 , the annual change was clearly lower, $-6 \%$. After a short period with no significant change, deposition turned to an increase of $5.5 \%$ per year, lasting for the period from 2002 to 2008. Despite the rather wide confidence limits for the annual increase in nitrate deposition during 2002-2008 (Table 3), the change is statistically significant and should be understood as an early warning of increasing nitrate deposition. The three most important contributors to the deposition of oxidized nitrogen in Finland are, according to the EMEP estimates, Russia, Finland and shipping emissions from the Baltic Sea and the North Sea, all with an approximately 20\% share (Gauss et al. 2012). Between 2000 and 2009, two of these increased (Tørseth et al. 2012). The nitrogen oxides $\left(\mathrm{NO}_{\mathrm{x}}\right)$ emissions from Russia increased by $35 \%$, the same change also being estimated for the emissions from the St. Petersburg area, and the emissions from shipping grew by 15\%-20\% (Tørseth et al. 2012). According to a more detailed analysis of the Baltic Sea shipping emissions based on the messages of the automatic identification system (AIS), which enable the positioning of ships with a high spatial resolution (Jalkanen et al. 2013), the $\mathrm{NO}_{\mathrm{x}}$ emissions were $17 \%$ higher than the EMEP estimates (Bartnicki et al. 2010, 2011) and increased by 14\% between 2006 and 2008 alone. An even larger increase in emissions from ships was detected in the Gulf of Finland,

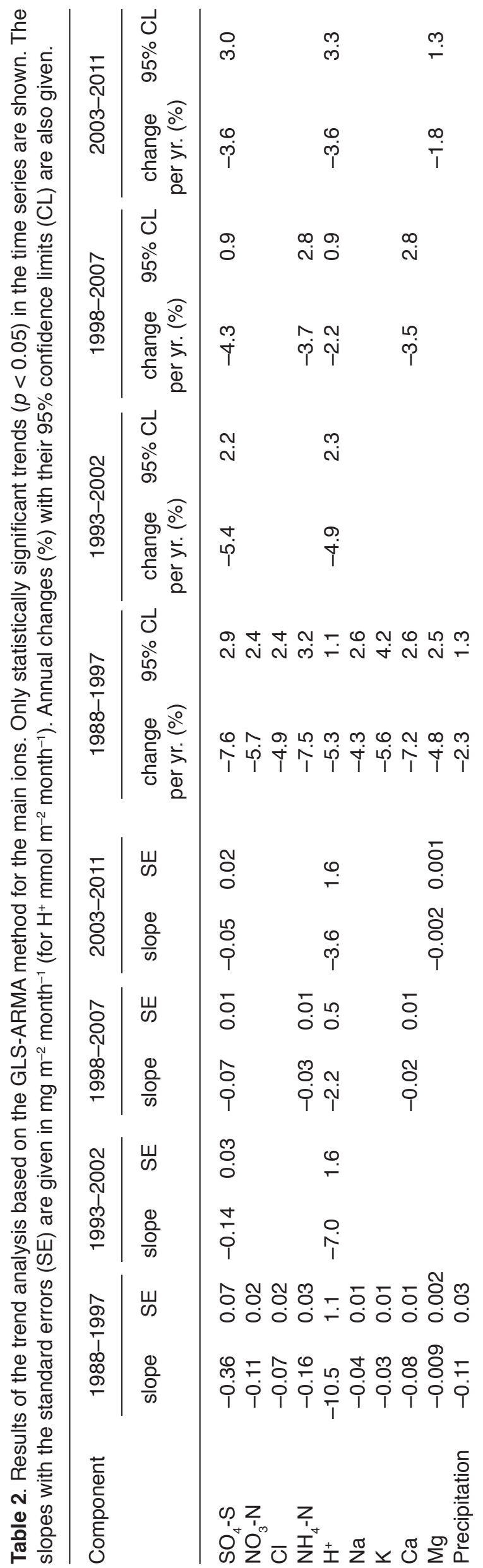


$100 \mathrm{~km}$ from Valkea-Kotinen in the direction of frequent transport of air masses to ValkeaKotinen (see section 'Transport of air masses to Valkea-Kotinen'). However, the domestic $\mathrm{NO}_{x}$ emissions declined by $25 \%$ and the total European emissions decreased by $7 \%$ between 2000 and 2009 (Tørseth et al. 2012). We assume that our method can detect an early indication of the increase in $\mathrm{NO}_{3}^{-}$deposition, even if it was only detected during the years 2002-2008. In an analysis of the EMEP monitoring data covering the 2000s, the average reduction in oxidized nitrogen was $12 \%$ in precipitation and $1 \%$ on particles, while some stations even measured an increase (Tørseth et al. 2012).

For the recovery processes of the environment, the finding of a recent increase in the $\mathrm{NO}_{3}^{-}$ deposition is a serious signal. As $\mathrm{N}$ retention is high in the terrestrial ecosystem of ValkeaKotinen (Vuorenmaa et al. 2012), the increased deposition might raise the risk of saturation and excess leaching of $\mathrm{NO}_{3}{ }^{-}$to surface waters. $\mathrm{N}$ has played a minor role in acidification in the past, but its relative importance is increasing because the $\mathrm{N}$ emissions have decreased much less than the $\mathrm{S}$ emissions. The increase in $\mathrm{NO}_{3}{ }^{-}$deposition might also strengthen the eutrophication of the Valkea-Kotinen ecosystem.

The concentrations of elements in the groundwater reflect the surrounding soil type and bedrock, as well as atmospheric deposition. The time series of the $\mathrm{NO}_{3}^{-}$concentration in groundwater from the Kellolähde spring enabled a preliminary study of whether the unusual pattern of $\mathrm{NO}_{3}^{-}$bulk deposition could be detected in groundwater. The trends in the $\mathrm{NO}_{3}^{-}$concentration in Kellolähde groundwater were also calculated with the ITSM program and showed a significant increase between 1987 and 1993, and a decrease between 1994 and 2000. The turning point in the concentration was about five years later than that for the bulk deposition. Both groundwater concentrations and depositions were smoothed with a filter, where the weighting coefficients are set to correspond to the ordinates of a Gaussian probability curve in order to remove the short-term variation and reveal the longest wavelength in the time series (Fig. 3). This smoothing method has been recommended (Mitchell et al. 1966) and used for meteorological time series analysis (Lindström and Alexandersson 2004). The Pearson correlation between the smoothed time series was high $\left(r_{\mathrm{P}}=0.96, p<0.01, n=81\right)$, suggesting an influence of $\mathrm{NO}_{3}^{-}$deposition on the general behaviour of the concentration in groundwater after a time lag of five years. Even for the original time series with dense short-term variations, a moderate correlation $\left(r_{\mathrm{P}}=0.46, p<0.01, n=\right.$ 81) was detected. However, the $\mathrm{NO}_{3}^{-}$concentration in groundwater levelled off after 2007, and did not show an increase, as occurred for bulk deposition after 2002. According to Backman (2004), the time lag between precipitation and groundwater quality, based on $\mathrm{pH}$ values in Kellolähde spring, was about two years. Our preliminary comparison suggested a longer time lag for $\mathrm{NO}_{3}^{-}$. This longer period is supported by the results of Kubin (1998) in a case involving the clear felling of two forests, where the nitrate concentrations in groundwater started to rise in the 3 rd to 5 th summer following site preparation. The groundwater wells were from 4 to $5 \mathrm{~m}$ in depth, and the depth of the groundwater varied seasonally, the mean being about $3 \mathrm{~m}$ (Kubin 1998). In the Kellolähde area, the minimum thickness of Quaternary deposits is $30 \mathrm{~m}$ (Backman 1999), so it could be assumed that the retention time for nitrate transport there could be longer, and even up to five years.

Table 3. Detailed analysis of nitrate bulk deposition at Valkea-Kotinen. Only statistically significant trends $(p<$ 0.05 ) in the time series based on the GLS-ARMA method are shown. The slopes with standard errors are given in $\mathrm{mg} \mathrm{m}^{-2}$ month $^{-1}$. Annual changes (\%) with their $\pm 95 \%$ confidence limits $(C L)$ are also given.

\begin{tabular}{lccccc}
\hline & $1988-1990$ & $1991-1997$ & $1998-2001$ & $2002-2008$ & $2009-2011$ \\
\hline Slope \pm SE & $-0.39 \pm 0.08$ & $-0.10 \pm 0.03$ & - & $0.05 \pm 0.02$ & - \\
Annual change $\pm 95 \%$ CL & $-16.6 \pm 6.6$ & $-6.4 \pm 3.7$ & - & $5.5 \pm 4.5$ & - \\
\hline
\end{tabular}




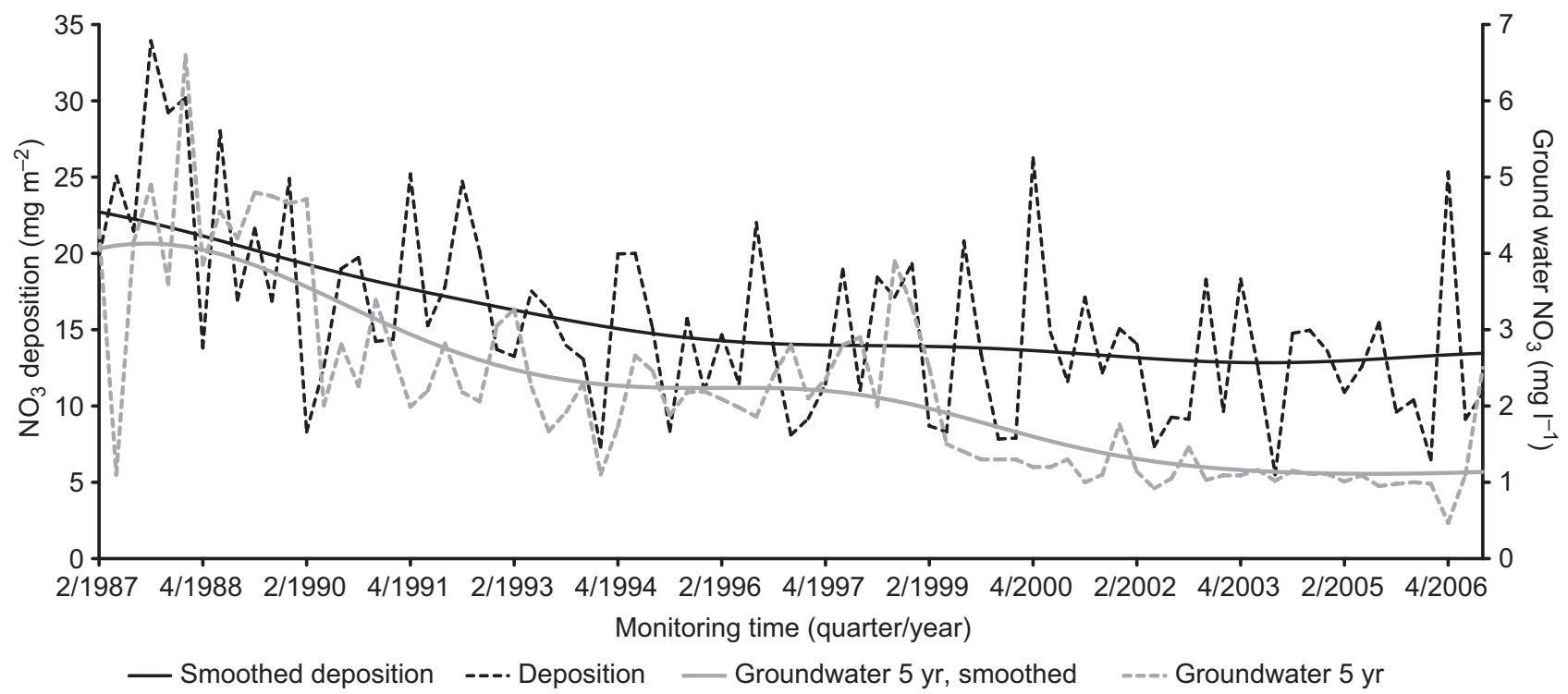

Fig. 3. Nitrate bulk deposition and nitrate in groundwater at Valkea-Kotinen. Groundwater concentrations are moved backwards by five years along the time axis to make the maximum periods overlap. Solid lines present original data smoothed with a filter with weights from the Gaussian distribution.

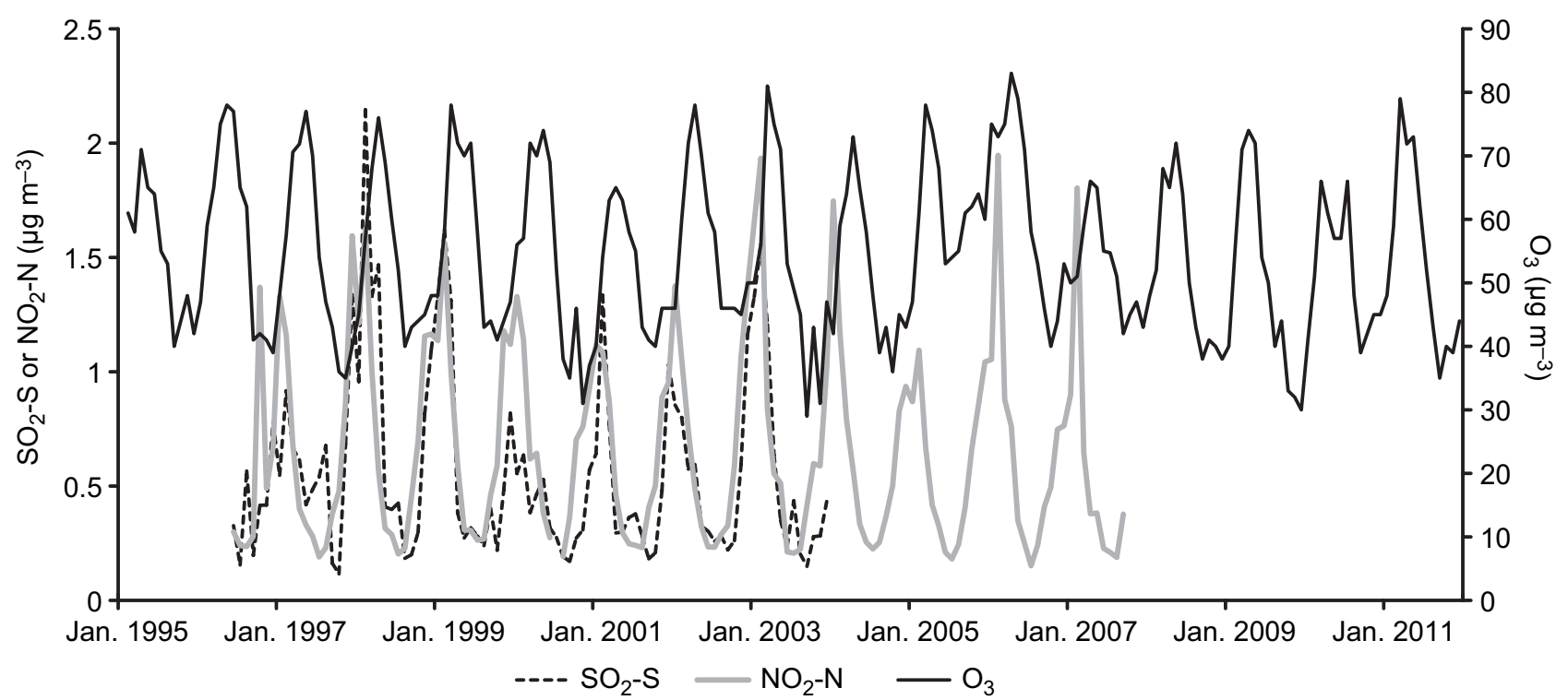

Fig. 4. Time series of the gaseous compounds at Valkea-Kotinen.

\section{Gases}

The time series of $\mathrm{SO}_{2}, \mathrm{NO}_{2}$ and $\mathrm{O}_{3}$ were shorter than those for depositions of the main ions, being 8,10 and 17 years, respectively. The high seasonal variation is typical for gaseous compounds (Fig. 4). Levels measured at Valkea-Kotinen were consistent with results from other background stations in southern Finland (Kulmala et al. 1998, Anttila and Tuovinen 2009). For $\mathrm{SO}_{2}$ and $\mathrm{NO}_{2}$, no statistically significant changes in the time series were detected. Instead, the mean monthly increase $\left( \pm\right.$ SE) in $\mathrm{O}_{3}$ during 1998-2007 was $0.05 \pm 0.02 \mu \mathrm{g} \mathrm{m}^{-3}$. The annual change $( \pm 95 \% \mathrm{CL})$ was $1.1 \% \pm 0.8 \%$.

The measurement period for the gases, especially for the acidifying compounds, was too short to provide full support for the effect studies in IM. Data from other southern Finland background stations, such as Ähtäri (ca. 160 km from Valkea-Kotinen), could be used to complete the pattern. The atmospheric concentrations, seasonal behaviour and trends of the $\mathrm{S}$ compounds and $\mathrm{NO}_{3}^{-}$are mainly controlled by changes in the well-mixed air masses over southern Finland, and were thus similarly recorded at two back- 

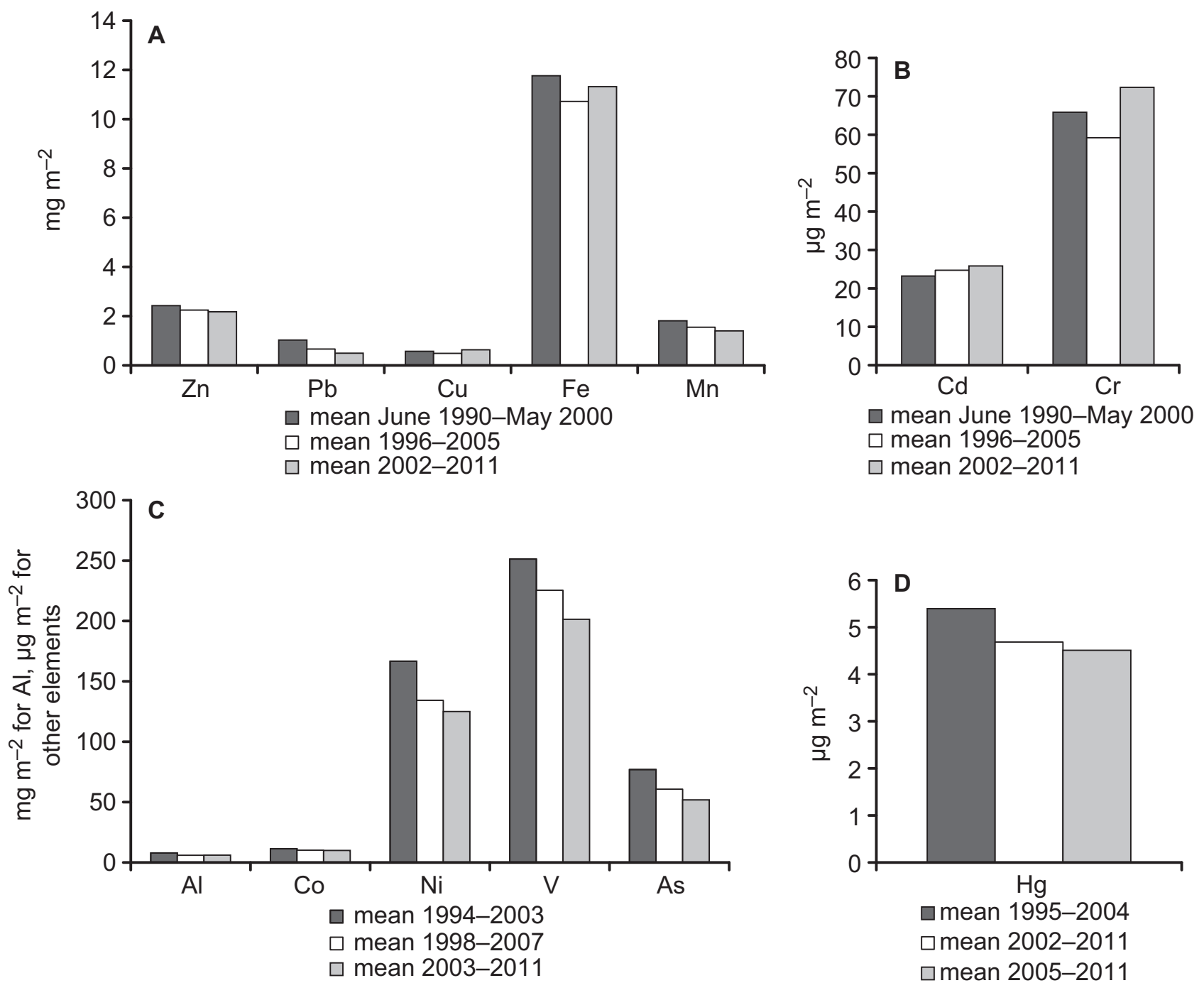

Fig. 5. Ten-year mean values of the bulk deposition of trace elements at Valkea-Kotinen. Note the different units for the separate components in C. For Al and Co (in panel C), the first column is the annual sum for 2003 and the second is the mean annual deposition for 2003-2007.

ground stations $70 \mathrm{~km}$ apart in a comparison of seven years of data (Ruoho-Airola 2012).

\section{Trace elements}

\section{Annual bulk deposition}

Since the starting time of monitoring of selected elements varied, three approximately 10-year periods were chosen to illustrate the levels of bulk deposition of the elements during their entire monitoring (Fig. 5). For zinc ( $\mathrm{Zn}), \mathrm{Pb}$, $\mathrm{Cd}$, copper $(\mathrm{Cu})$, iron $(\mathrm{Fe})$, manganese $(\mathrm{Mn})$ and chromium $(\mathrm{Cr})$, these periods were 1990-2000, 1996-2005 and 2002-2011, while for nickel (Ni), vanadium (V) and arsenic (As), the periods covered the years 1994-2003, 1998-2007 and 2003-2011. Finally, for $\mathrm{Hg}_{\text {tot }}$, the periods covered the years 1995-2004, 2002-2011 and 2005-2011, where the first period included data only from the Janakkala station, the second period data from both Janakkala and ValkeaKotinen, and the third period comprised only Valkea-Kotinen data.

The average bulk deposition of $\mathrm{Pb}$ decreased by $35 \%$ between each of the three 10 -year periods, while for As the decline was about $20 \%$ (Fig. 5). Lower reductions in the mean annual levels were measured for $\mathrm{Zn}, \mathrm{Mn}, \mathrm{Ni}$ and $\mathrm{V}$. For $\mathrm{Hg}_{\text {tot }}$, the mean levels in 2002-2011 and 2005-2011 were about 15\% lower than that in 1995-2004. However, translocation of the measurement site from Janakkala to Valkea-Kotinen in 2005 may have had some influence on $\mathrm{Hg}_{\text {tot }}$ concentrations, even though the sites were 
located only $30 \mathrm{~km}$ apart. In contrast to the other elements, the $\mathrm{Cd}$ level increased by $5 \%$ between the periods (Fig. 5).

The measured levels of trace elements were somewhat higher than at most other Finnish background stations, but close to or lower than the levels at background stations in Sweden, Norway and Germany (Bringmark et al. 2013, Kyllönen et al. 2009). Domestic emissions are higher in the southern part of Finland, where the influence of the heavy European emission sources is also stronger than elsewhere in the country.

A recent paper by Kyllönen et al. (2009) discusses the trace element levels in detail and also includes data from the Valkea-Kotinen station.

\section{Trends in bulk deposition of trace elements}

The ITSM analysis of trace elements was performed for the same 10-year periods as for the annual bulk depositions. The outcome of the trend analysis can be summarized as follows: (1) during the first 10-year period, the bulk deposition of all elements except $\mathrm{Cd}$ and $\mathrm{Hg}_{\text {tot }}$ decreased; (2) $\mathrm{Cd}, \mathrm{Fe}$ and $\mathrm{Cr}$ deposition increased during 1996-2005; (3) the decline in $\mathrm{Pb}, \mathrm{As}, \mathrm{Ni}$ and $\mathrm{V}$ deposition covered the whole measurement period (see Table 4).

The trace elements can be grouped according to their enrichment factors, which compare the amount of the element to a reference element assumed to be entirely from crustal sources. Cd, $\mathrm{As}, \mathrm{Pb}$ and $\mathrm{Zn}$ are highly enriched and mostly of anthropogenic origin. $\mathrm{Cu}, \mathrm{Ni}$ and $\mathrm{V}$ are less enriched, but still significantly so. $\mathrm{Mn}, \mathrm{Cr}, \mathrm{Co}$, $\mathrm{Al}$ and $\mathrm{Fe}$ are only slightly enriched and generally of crustal origin, with crustal weathering and wind re-suspension being important sources. (Berg et al. 1994, Kyllönen et al. 2009). For the IM programme, the components having higher enrichment factors are the most interesting ones and are discussed in detail here.

Anthropogenic trace element emissions decreased in the 1980s and 1990s due to strict emission regulations and consequent improvements in the control technologies in Finland and elsewhere in Europe (Pacyna and Pacyna 2001). The reduced emissions, together with the slight decrease in the precipitation amount, have led to a decline in the bulk deposition of trace elements of anthropogenic origin, except for $\mathrm{Cd}$, which increased at Valkea-Kotinen by $2 \%$ annually between 1996 and 2005. Cd deposition also increased between 1996 and 2005 at three of the six other Finnish background stations of FMI (data not shown). The annual change was $3 \% \pm$ $2 \%$ in Oulanka, $6 \% \pm 5 \%$ in Hailuoto and $11 \% \pm$ $7 \%$ in Pallas. In the EMEP data, the decline in $\mathrm{Cd}$ deposition also levelled off at several sites after 2000 (Tørseth et al. 2012). In addition, the deposition of Cd increased in Russia between 2000 and 2005 (Travnikov et al. 2012). For the Finnish Cd deposition, foreign sources contributed $50 \%$ and $70 \%$ in 1990 and 2000, respectively (Travnikov et al. 2012), and domestic factors therefore also affected the $\mathrm{Cd}$ level. The wind re-suspension of cadmium accumulated in soil significantly contributes to cadmium deposition (Travnikov et al. 2012), and its amount might vary considerably depending on changing meteorological factors, including the length of the snow-free period (Kyllönen et al. 2009). In an earlier study based on annual bulk deposition values and covering all Finnish background stations, no significant change in $\mathrm{Cd}$ deposition was detected between 1998 and 2007 (Kyllönen et al. 2009), which shows the higher power for detecting trends with the ITSM method using monthly values. Evidently, the pattern of the highly harmful Cd deposition has changed in background areas of Finland, and further research on this is needed.

$\mathrm{Pb}$ and $\mathrm{As}$ deposition in Valkea-Kotinen declined during all periods calculated. $\mathrm{Pb}$ emissions and depositions have decreased widely in Europe due to the introduction of low-leaded and unleaded gasoline (Pacyna and Pacyna 2001, Travnikov et al. 2012). Emissions of As have strongly declined in Poland, which has most likely had a considerable effect on the Finnish deposition (Travnikov et al. 2012).

$\mathrm{Ni}$ and V depositions decreased in 19942003 and 2003-2011. These elements are intermediately enriched, oil combustion being an important emission source for both (Pacyna and Pacyna 2001). Domestic emissions of Ni have decreased since 1990 (www.ymparisto.fi/fi-FI/ Kartat_ja_tilastot/Ilman_epapuhtauksien_paastot), but for $\mathrm{V}$ the domestic emission time series 


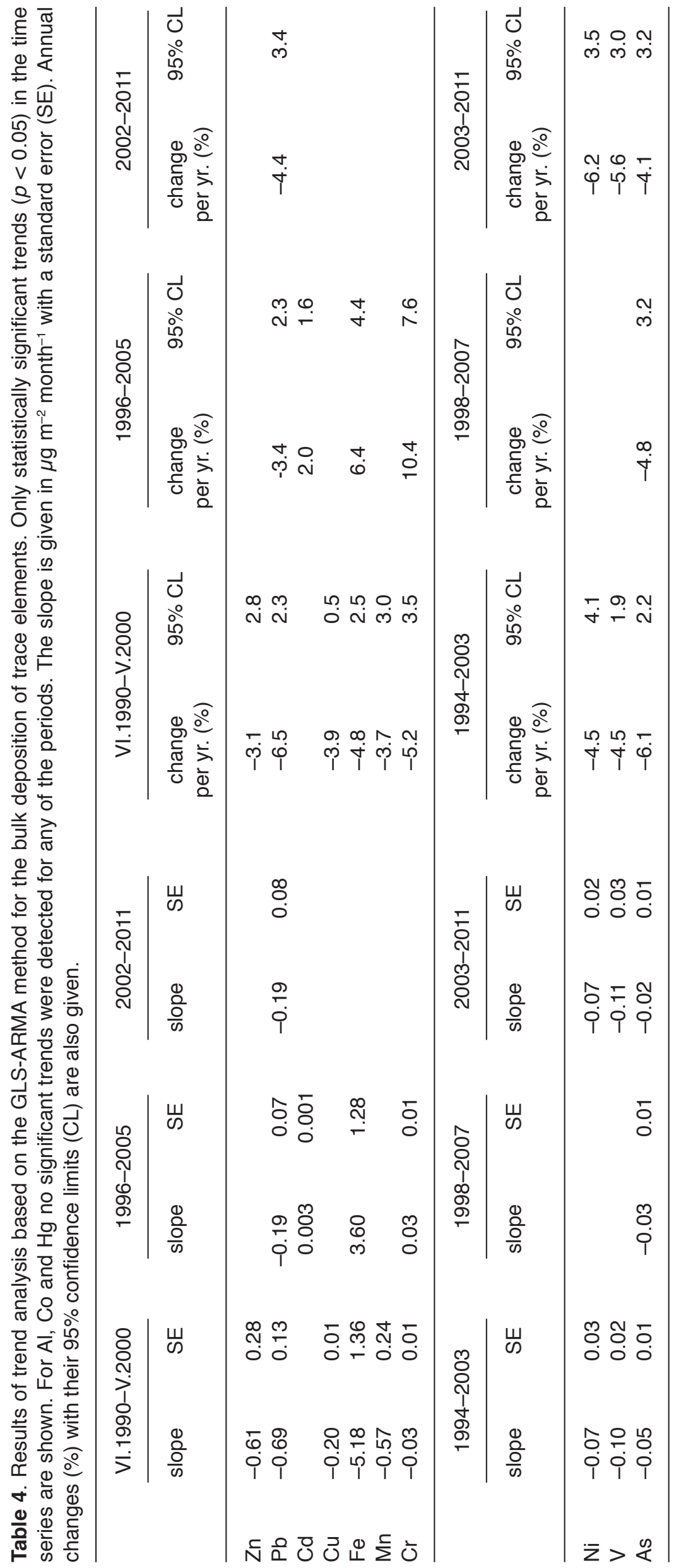


only cover the years 2000-2004. Likewise, no EMEP emission estimates are available for $\mathrm{V}$ and only for individual years for Ni. The development of the $\mathrm{V}$ and $\mathrm{Ni}$ depositions at ValkeaKotinen is a positive signal, which cannot be examined here in more detail because of inadequate emission estimates.

No statistically significant trends were found in $\mathrm{Hg}_{\text {tot }}$ deposition in any of the studied time series, although the mean values of the three time series decreased. Furthermore, during the first period of 1995-2004, an apparent decreasing trend was masked by two individual high monthly values. However, both of these peaks occurred in July, when the highest $\mathrm{Hg}_{\text {tot }}$ deposition is expected. When replacing these two values from the 10-year dataset of 120 values with July averages, a statistically significant annual trend of $-3.1 \% \pm 2.9 \%$ is found. Similarly, a decreasing trend during 1995-2002 was also found at five coastal stations around the North Sea in a study by Wängberg et al. (2007). The recorded decreases in deposition are mainly a result of improved control measures in coal power plants, which are the biggest anthropogenic-mercury emitters. While reducing $\mathrm{SO}_{2}$ and particle emissions, desulphurization techniques also effectively lower $\mathrm{Hg}$ emissions.

\section{Transport of air masses to Valkea-Kotinen}

The site analysis of the IM stations demonstrated that possible changes at the Finnish IM stations are not due to changes in local emissions, and that Valkea-Kotinen was representative of clean areas in southern Finland (Ruoho-Airola et al. 1998). The main contributor to Finnish air quality and atmospheric deposition in background areas is long-range transport from different parts of Europe (Nyíri et al. 2010, Travnikov et al. 2012). Thus, estimation of the transport of air masses to Valkea-Kotinen indicates possible source areas of the atmospheric load. The transport pattern was compiled from the trajectories calculated in the EMEP programme for 1997-2006 (www.EMEP.int).

The sectoral distribution roughly illustrates the relative importance of different directions of transport to Valkea-Kotinen (Fig. 6). In summer
(Fig. 6A), transport from the southwest, west, northwest and north dominated, while transport from the south, southeast and east was infrequent. In winter (Fig. 6B), the pattern of transport closely resembled the corresponding distribution in summer, and only a small shift from the sector towards the northeast to the sector towards the west was detected. The frequency of transport from different directions to ValkeaKotinen in summer and winter did not change significantly during 1997-2006.

From the Finnish perspective, the emissions of sulphur dioxide are greatest in the countries to the south, southwest and west of Finland, whereas the strongest emission fields of $\mathrm{NO}_{x}$ and ammonia are located to the southwest and west of Finland (http://www.ceip.at/webdab-emission-database/). For many of the trace elements in this study, the most important source areas are located in the southeast to southwest sectors. Thus, changes in emissions in the sectors ranging from the southeast to the west contributed greatly to the air quality and atmospheric deposition at Valkea-Kotinen, as was shown to be the case for the $\mathrm{S}$ and $\mathrm{N}$ exposure in Ähtäri (RuohoAirola et al. 2004), located $160 \mathrm{~km}$ to the northwest of Valkea-Kotinen. The different development of $\mathrm{NO}_{3}^{-}$deposition in Valkea-Kotinen as compared with that of the other elements might be connected to increased Russian emissions (Tørseth et al. 2012) and ship traffic emissions in the Baltic Sea (Bartnicki et al. 2010, 2011, Jalkanen et al. 2013), and the unchanged $\mathrm{NO}_{\mathrm{x}}$ emissions in the EMEP domain (Fageli et al. 2012), all in the period 2002-2008.

\section{Conclusions}

A significant downward trend in bulk depositions of all main ions at Valkea-Kotinen was detected in the period 1988-1997. Moreover, for all trace elements except $\mathrm{Cd}$ and $\mathrm{Hg}_{\text {tot }}$, bulk deposition declined during the first ten years of measurement. Depending on the component, the monitoring of trace elements began between 1990 and 1995, and for Al and Co in 2003. Significant downward trends were recorded during the entire measurement period for $\mathrm{SO}_{4}{ }^{2-}, \mathrm{H}^{+}, \mathrm{Pb}$, $\mathrm{As}, \mathrm{Ni}$ and $\mathrm{V}$, which provides positive evidence 

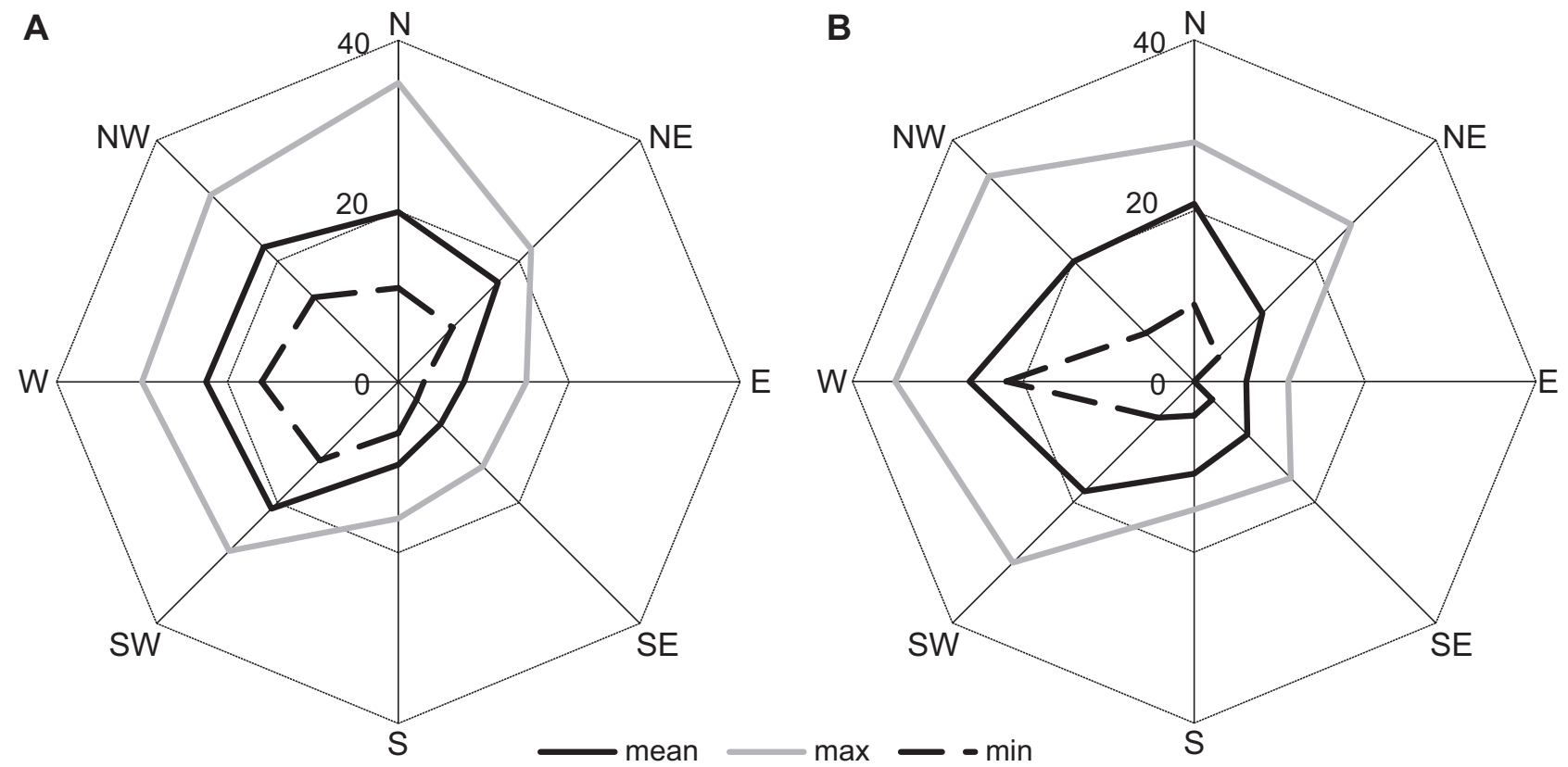

Fig. 6. Mean, maximum and minimum values for the transport of air from different sectors to the Valkea-Kotinen area in 1997-2006. Calculated as days of transport in the (A) summer and (B) winter seasons. Trajectory data from the EMEP programme (www.EMEP.int).

of successful emission reductions for these elements or their precursors.

In recent years, the $\mathrm{N}$ cycle in the environment has attracted increasing interest, one reason being the slower decline in $\mathrm{N}$ emissions as compared with that in $\mathrm{S}$ emissions. In contrast to the general decreasing trend for acidifying compounds, bulk deposition of $\mathrm{NO}_{3}^{-}$increased during 2002-2008 at Valkea-Kotinen. Further studies might reveal whether the situation is similar at other background stations in Finland, and confirm our assumption that this negative development has resulted from increased Russian emissions, ship traffic emissions in the Baltic Sea and unchanged $\mathrm{NO}_{\mathrm{x}}$ emissions in the EMEP domain in 2002-2008.

The high $\mathrm{NO}_{3}{ }^{-}$concentrations in groundwater are generally reported to result from agricultural activities. In the case of a large groundwater reservoir in a pristine state, the trend for atmospheric $\mathrm{NO}_{3}^{-}$might strongly influence the water quality, as our results suggest. The hydrological continuum of $\mathrm{NO}_{3}^{-}$in deposition to groundwater in Valkea-Kotinen should be studied in more detail, taking into account inter alia the soil and geological structure.

Bulk deposition of Cd increased by $2 \%$ annually between 1996 and 2005, after which no further significant changes were detected. An increase in $\mathrm{Cd}$ deposition was also detected at other Finnish background stations and in Russia in 2000-2005. Even though the levels measured at Valkea-Kotinen are low as compared with those in areas in central Europe, the element is highly enriched in the environment and harmful to ecosystems. The problem of no response in the Valkea-Kotinen catchment to the declining $\mathrm{Cd}$ emissions warrants deeper analysis.

The Integrated Monitoring programme has investigated the effects of atmospheric loading on ecosystems. Because the Valkea-Kotinen catchment is not substantially affected by local emissions but is rather under the effect of longrange pollutant transport, estimation of the transport pattern of air to the study area binds the results obtained in all of the articles in this special issue to the development of European emissions.

\section{References}

Anttila P. \& Tuovinen J.-P. 2009. Trends of primary and secondary pollutant concentration in Finland in 1994-2007. Atmos. Environ. 44: 30-41.

Backman B., Lahermo P., Väisänen U., Paukola T., Juntunen 
R., Karhu J., Pullinen A., Rainio H. \& Tanskanen H. 1999. Geologian ja ihmisen toiminnan vaikutus pohjaveteen: seurantatutkimuksen tulokset vuosilta 1969-1996 [The effect of geological environment and human activities on groundwater in Finland: the results of monitoring in 1969-1996]. Report of Investigations 147, Geological Survey of Finland, Espoo. [In Finnish with English summary].

Backman B. 2004. Groundwater quality, acidification, and recovery trends between 1969 and 2002 in South Finland. Geological Survey of Finland. Bulletin 401, Geological Survey of Finland, Espoo.

Bartnicki J., Semeena V.S. \& Fagerli H. 2011. Atmospheric deposition of nitrogen to the Baltic Sea in the period 1995-2006. Atmos. Chem. Phys. 11: 10057-10069.

Bartnicki J., Gusev A., Aas W. \& Valiyaveetil S. 2010. Atmospheric supply of nitrogen, lead, cadmium, mercury and dioxines/furanes to the Baltic Sea in 2008. EMEP/ MSC-W Technical Report 2/2010, Oslo.

Berg T., Royset O. \& Steinness E. 1994. Trace elements in atmospheric precipitation at Norwegian background stations (1989-1990) measured by ICP-MS. Atmos Environ. 28: 3519-3536.

Bergström I., Mäkelä K. \& Starr M. (eds.) 1995. Integrated Monitoring Programme in Finland. First National Report, Environmental Policy Department, Ministry of Environment, Helsinki.

Bringmark L., Lundin L., Augustaitis A., Beudert B., Dieffenbach-Fries H., Dirnböck T., Grabner M.-T., Hutchins M., Kram P., Lyulko I., Ruoho-Airola T. \& Vana M. 2013. Trace metal budgets for forested catchments in Europe $-\mathrm{Pb}, \mathrm{Cd}, \mathrm{Hg}, \mathrm{Cu}$ and $\mathrm{Zn}$. Water Air Soil Pollut. 224: 1520, doi:10.1007/s11270-013-1502-8.

Brockwell P.J. \& Davies R.A. 2002. Introduction to time series and forecasting, 2nd ed. Springer-Verlag, New York.

EMEP 2001. EMEP/CCC. Manual for sampling and chemical analysis [revised November 2001]. EMEP/CCCReport 1/95, Norwegian Institute for Air Research, Kjeller. [Available at http://www.nilu.no/projects/ccc/ manual/index.html].

Fagerli H. \& Aas W. 2008. Trends of nitrogen in air and precipitation: model results and observations at EMEP sites in Europe, 1980-2003. Environ. Poll. 154: 448-461.

Fagerli H., Gauss M., Benedictow A., Jonson J.E., Nyíri A., Schulz M., Simpson D., Steensen B.M., Tsyro S., Valdebenito A., Wind P., Shamsudheen S.V., Aas W., Hjellbrekke A.-G., Mareckova K., Wankmüller R., Solberg S., Svendby T., Vieno M., Thunis P., Cuvelier K., Koffi B. \& Bergström R. 2012. Transboundary acidification, eutrophication and ground level ozone in Europe in 2010. EMEP Report 1/2012, Norwegian Meteorological Institute, Oslo.

Ferm M. 1991. A sensitive diffusional sampler. IVL Report L91-172, Swedish Environmental Research Institute, Göteborg.

Fowler D., Muller J., Smith R.I., Cape J.N. \& Erisman J.W. 2005. Nonlinearities in source receptor relationships for sulfur and nitrogen compounds. Ambio 34: 41-46.

ICP IM Programme Centre, 1998. Manual for Integrated
Monitoring. Revised 2004. Finnish Environment Institute, Helsinki.

Gauss M., Nyíri Á., Steensen B.M. \& Klein. H. 2012. Transboundary air pollution by main pollutants $\left(\mathrm{S}, \mathrm{N}, \mathrm{O}_{3}\right)$ and PM in 2010, Finland. MSC-W Data Note 1/2010, Norwegian Meteorological Institute, Oslo.

Jalkanen J.-P., Johansson L. \& Kukkonen J. 2013. A comprehensive inventory of the ship traffic exhaust emissions in the Baltic Sea from 2006 to 2009. Ambio, doi:10.1007/ s13280-013-0389-3. [In press].

*Jylhä K., Laapas M., Ruosteenoja K., Arvola L., Drebs A., Kersalo J., Saku S., Gregow H., Hannula H.-R. \& Pirinen P. 2014. Climate variability and trends in the Valkea-Kotinen region, southern Finland: comparisons between the past, current and projected climates. Boreal Env. Res. 19 (suppl. A): 4-30.

Kubin E. 1998. Leaching of nitrate nitrogen into the groundwater after clear felling and site preparation. Boreal Env. Res. 3: 3-8.

Kulmala A., Leinonen L., Ruoho-Airola T., Salmi T. \& Waldén J. 1998. Air quality trends in Finland. Air quality measurements. Finnish Meteorological Institute, Helsinki.

Kyllönen K., Karlsson V. \& Ruoho-Airola T. 2009. Trace element deposition and trends during a ten year period in Finland. Sci. Total Environ. 407: 2260-2269.

Lindström G. \& Alexandersson H. 2004. Recent mild and wet years in relation to observation records and future climate change in Sweden. Ambio 33: 183-186.

Löfgren S., Aastrup M., Bringmark L., Hultberg H., LewinPihlblad L., Lundin L., Karlsson G.P. \& Thunholm B. 2011. Recovery of soil water, groundwater, and streamwater from acidification at the Swedish Integrated Monitoring Catchments. Ambio 40: 836-856.

Lövblad G., Tarrasón L., Tørseth K. \& Dutchak S. 2004. EMEP Assessment, Part I: European perspective. Norwegian Meterorological Institute, Oslo.

Mitchell J.M.Jr., Dzerdzeevskii B., Flohn H., Hofmeyr W.L., Lamb H.H., Rao K.N. \& Wallén C.C. 1966. Climatic change. Technical Note 79, WMO 195 TP. 100, World Meteorological Organization, Geneva.

Nyíri Á., Gauss M. \& Klein H. 2010. Transboundary air pollution by main pollutants $\left(\mathrm{S}, \mathrm{N}, \mathrm{O}_{3}\right)$ and PM. Finland. MSC-W Data Note 1/2010, Norwegian Meteorological Institute, Oslo.

Pacyna J.M. \& Pacyna E.G. 2001. An assessment of global and regional emissions of trace metals to the atmosphere from anthropogenic sources worldwide. Environ. Rev. 9: 269-298.

Porvari P. 2003. Sources and Fate of Mercury in Aquatic Ecosystems. Monographs of the Boreal Environment Research 23: 1-52.

Ruoho-Airola T. 2012. Comparison of atmospheric concentrations of sulphur and nitrogen compounds, chloride and base cations at Ähtäri and Hyytiälä, Finland. Boreal Env. Res. 17: 128-138.

Ruoho-Airola T. \& Leinonen L. 1997. Reliability of Deposition Data. Parallel Measurements in the UN/ECE/IM Programme. In: Schaug J. (ed.), EMEP-WMO workshop on data analysis, validation and reporting, Usti nad 
Labem, Czech Republic, 1997, Norwegian Institute for Air Research, Kjeller, pp. 127-130.

Ruoho-Airola T., Syri S. \& Nordlund G. 1998. Acid deposition trends at the Finnish Integrated Monitoring catchments in relation to emission reductions. Boreal Env. Res. 3: 205-219.

Ruoho-Airola T., Anttila P. \& Salmi T. 2004. Airborne sulfur and nitrogen in Finland - trends and exposure in relation to air transport sector. J. Environ. Monit. 6: 1-11.

Ruoho-Airola T., Alaviippola, B., Salminen K. \& Varjoranta R. 2003. An investigation of base cation deposition in Finland. Boreal Env. Res. 8: 83-95.

Seinfeld J. H. \& Pandis S.N. 2006. Atmospheric chemistry and physics: from air pollution to climate change, 2nd ed. John Wiley \& Sons, New York.

Travnikov O., Ilyin I., Rozovskaya O., Varygina M., Aas W., Uggerud H.T., Mareckova K. \& Wankmueller R. 2012. Long-term changes of heavy metal transboundary pollution of the environment (1990-2010). EMEP Status Report 2/2012, Norwegian Institue for Air Research, Kjeller.

Tørseth K., Aas W., Breivik K., Fjæraa A.M. Fiebig M., Hjellbrekke A.G., Lund Myhre C., Solberg S. \& Yttri K.E. 2012. Introduction to the European Monitoring and Evaluation Programme (EMEP) and observed atmos- pheric composition change during 1972-2009. Atmos. Chem. Phys. 12: 5447-5481.

Ukonmaanaho L., Starr M., Hirvi J.-P., Kokko A., Lahermo P., Mannio J., Paukola T., Ruoho-Airola T. \& Tanskanen H. 1998. Heavy metal concentrations in various aqueous and biotic media in Finnish Integrated Monitoring catchments. Boreal Env. Res. 3: 235-249.

Vuorenmaa J., Kleemola S. \& Forsius M. 2009. Trend assessment of bulk deposition, throughfall and runoff water/ soil water chemistry at ICP IM sites. The Finnish Environment 23: 36-63.

*Vuorenmaa J., Salonen K., Arvola L., Mannio J., Rask M. \& Horppila P. 2014. Water quality of a small headwater lake reflects long-term variations in deposition, climate and in-lake processes. Boreal Env. Res. 19 (suppl. A): 47-65.

Vuorenmaa J., Kleemola S., Forsius M., Lundin L., Augustaitis A., Beudert B., de Wit H., Frey J., Indriksone I., Tait D., Krám P. \& Váňa M. 2012. Sulphur and nitrogen input-output budgets at ICP Integrated Monitoring sites in Europe. Finnish Environment 28: 23-34.

Wängberg I., Munthe J., Berg T., Ebinghaus R., Kock H.H., Temme C., Bieber E., Spain T.G. \& Stolk A. 2007. Trends in air concentration and deposition of mercury in the coastal environment of the North Sea Area. Atmos. Environ. 41: 2612-2619. 
FINNISH METEOROLOGICAL INSTITUTE

Erik Palménin aukio 1

P.O. Box 503

FI-00560 HELSINKI

tel. +358295391000

\section{WWW.FMI.FI}

FINNISH METEOROLOGICAL INSTITUTE CONTRIBUTIONS No. 164

ISSN 0782-6117

ISBN 978-952-336-103-4 (paperback)

ISBN 978-952-336-104-1 (pdf)

https://doi.org/10.35614/isbn.9789523361041
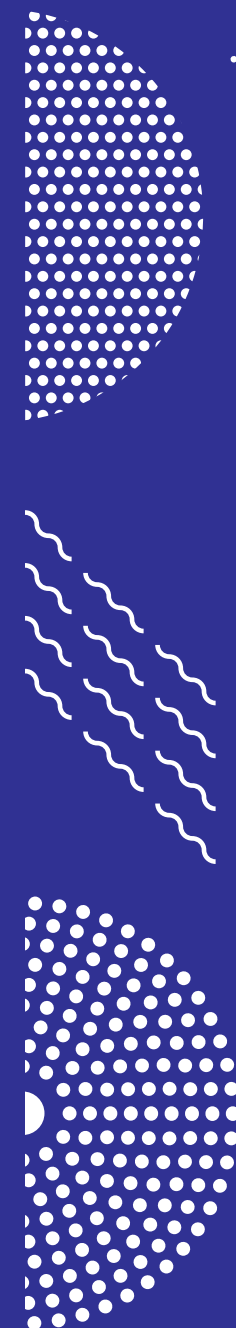

Helsinki, 2020

Edita Prima Oy 